

INSTITUTO DE BIOLOGÍA MOLECULAR Y CELULAR DEL CÁNCER
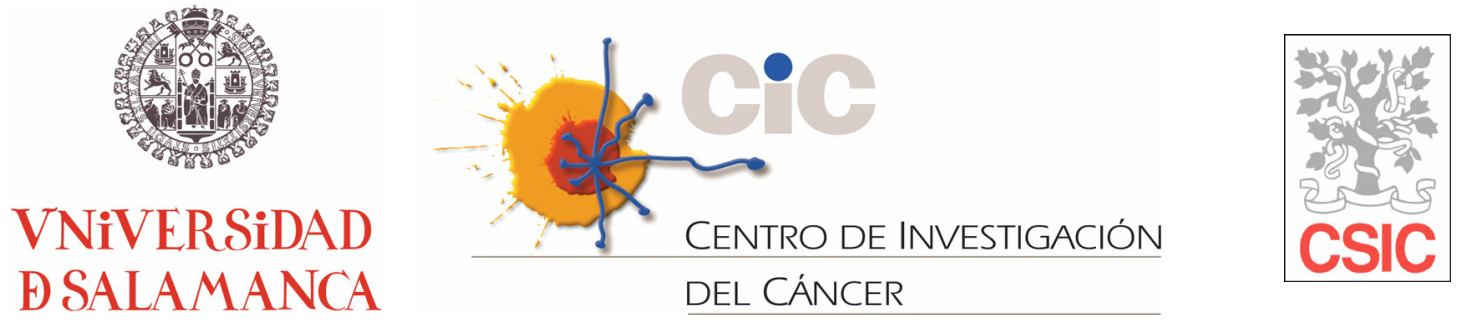

\section{REGULACIÓN DE LA QUINASA VRK1 POR PIk3 Y SU IMPLICACIÓN EN LA DINÁMICA DEL APARATO DE GOLGI EN DIVISIÓN CELULAR}

\section{TESIS DOCTORAL}

Inmaculada López Sánchez

2010 

D. PEDRO A. LAZO-ZBIKOWSKI, PROFESOR DE INVESTIGACIÓN DEL CONSEJO SUPERIOR DE INVESTIGACIONES CIENTÍFICAS (CSIC)

\section{CERTIFICA}

Que la memoria titulada "Regulación de la quinasa VRK1 por Plk3 y su implicación en la dinámica del aparato de Golgi en división celular" presentada por la licenciada INMACULADA LÓPEZ SÁNCHEZ ha sido realizada bajo su dirección en el Instituto de Biología Molecular y Celular del Cáncer y reúne, a su juicio, originalidad y contenidos suficientes para que sea presentada ante el tribunal correspondiente y optar al grado de Doctor por la Universidad de Salamanca.

Y para que así conste, a efectos legales, expide el presente certificado en Salamanca a 26 de Abril de 2010.

Fdo. Pedro A. Lazo-Zbikowski 

Esta memoria ha sido realizada siendo Inmaculada López Sánchez beneficiaria de una beca de Formación de Personal Investigador (FPI) del Ministerio de Educación y Ciencia para la realización de la tesis doctoral (2005-2009).

La investigación en el laboratorio ha sido financiada por proyectos de:

- Ministerio de Educación y Ciencia (SAF2004-02900; SAF2007-60242 y CSD2007-0017)

- Junta de Castilla y León, Consejería de Educación (CSI05A05; CSI14A08 y GR15)

- Junta de Castilla y León, Consejería de Sanidad (SAN/1052/SA04/05; SAN/673/SA05/08)

- Federación Cajas de Ahorro de Castilla y León.

- Fundación de Investigación Médica MM. 

La ciencia es siempre una búsqueda, jamás un descubrimiento real.

Es un viaje, nunca una llegada.

KARL POPPER

A mis padres, a mis hermanos

y a Antonio 

Îndice 



\section{Introducción}

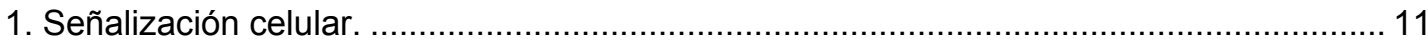

2. Plataformas de señalización en orgánulos subcelulares. .............................................. 11

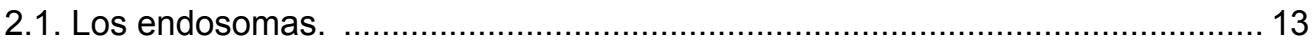

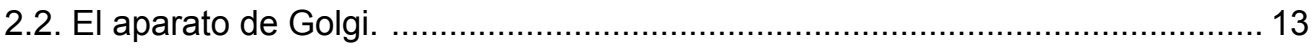

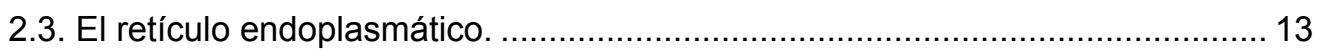

3. El quinoma humano: familias de quinasas VRK y Plk. ............................................... 14

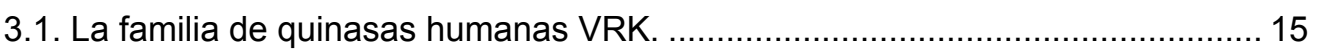

3.1.1. Motivos estructurales de las quinasas humanas VRK .................................. 17

3.1.2. Estructura del dominio catalítico de la familia VRK...................................... 19

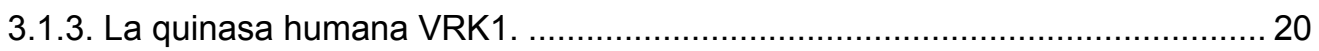

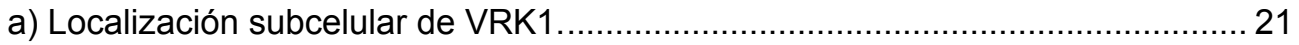

b) Sustratos de VRK1: factores de transcripción. ............................................... 21

c) Implicación de VRK1 en proliferación y división celular...................................... 23

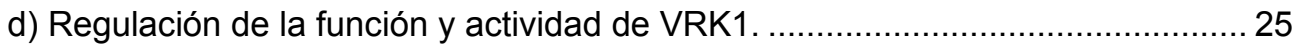

e) VRK1 y su relación con enfermedades humanas............................................. 26

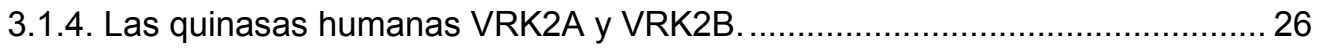

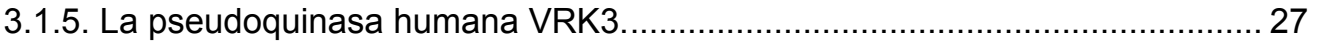

3.2. La familia de quinasas humanas Plk ............................................................. 27

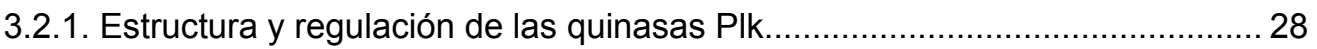

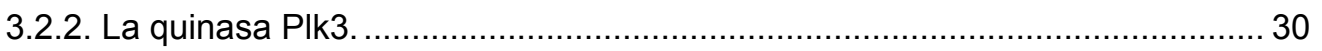

a) Expresión, actividad y localización de Plk3 .................................................. 30

b) Función de Plk3 en respuesta a estrés genotóxico. .......................................... 31

c) Implicación de Plk3 en proliferación y división celular. ..................................... 33

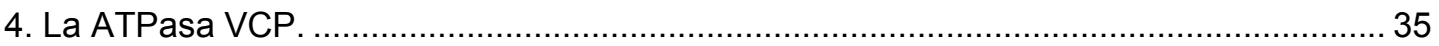

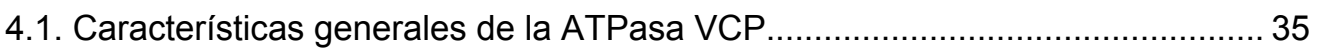

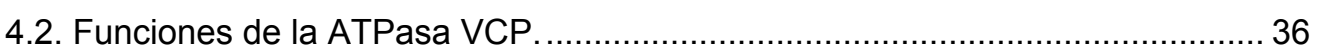

4.2.1. Implicación de VCP en la fusión de membranas. .......................................... 38

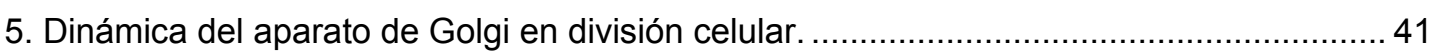

5.1. Organización y función del aparato de Golgi. ............................................... 41

5.2. Fragmentación del aparato de Golgi en la transición G2/mitosis....................... 42

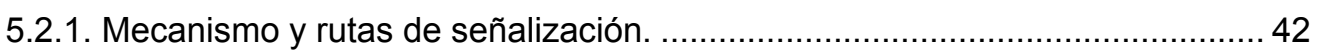

a) Rotura de las uniones laterales de las cisternas (fase I). ................................. 42

b) Desensamblaje de las cisternas (fase II). ................................................... 45

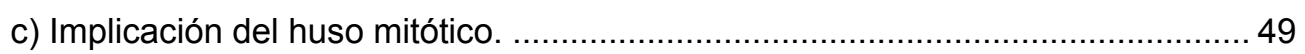

5.3. Reensamblaje del aparato de Golgi en telofase. .......................................... 50 


\section{Resultados}

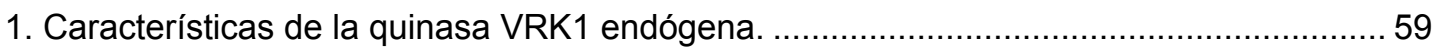

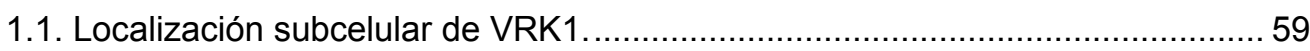

1.2. El anticuerpo $1 F 6$ identifica una subpoblación de VRK1 en el

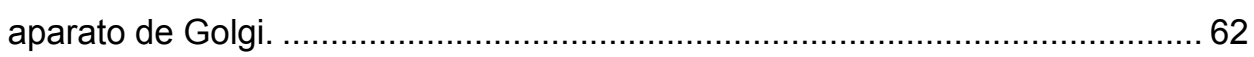

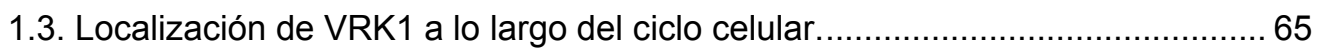

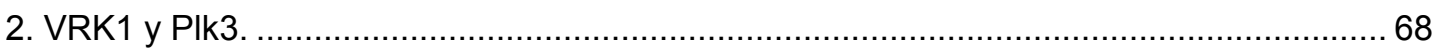

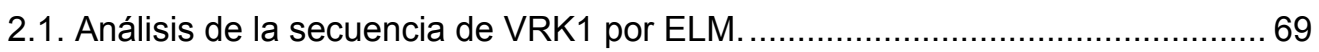

2.2. Identificación de Plk3 como proteína candidata a interaccionar con VRK1 mediante técnicas proteómicas...................................................... 71

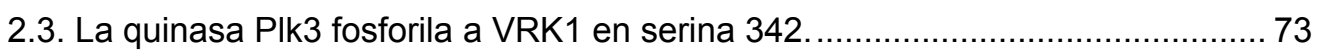

2.4. Plk3 no fosforila a otras proteínas VRK. ................................................... 75

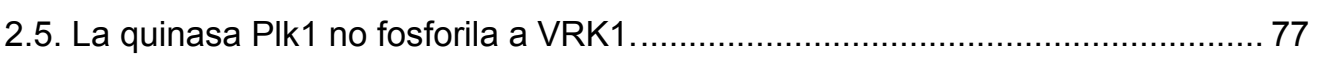

2.6. La sobreexpresión de Plk3 provoca un incremento de la

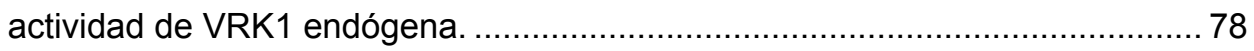

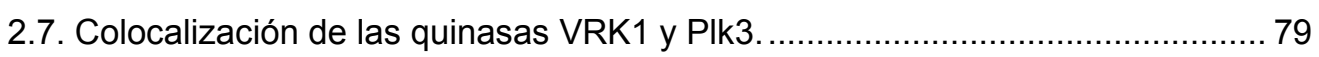

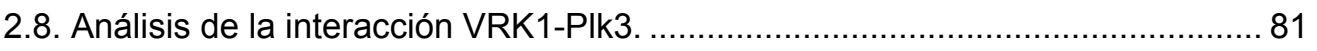

2.8.1. VRK1 no forma complejos proteicos de alto peso molecular......................... 81

2.8.2. Interacción de las proteínas VRK1 y Plk3 in vivo........................................... 82

2.8.3. Determinación de la zona de interacción de VRK1 con Plk3 ......................... 85

2.9. Implicación de VRK1 en la fragmentación del aparato de

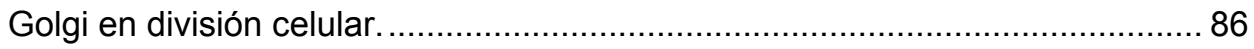

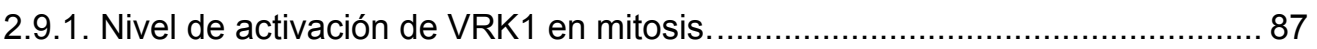

2.9.2. Correlación de los niveles de activación de MEK1, Plk3 y

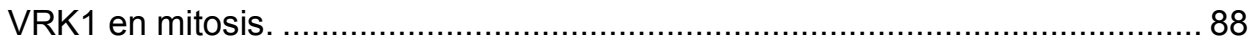

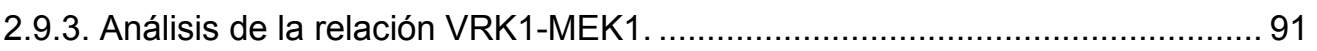

a) La sobreexpresión de MEK1 provoca un aumento de la

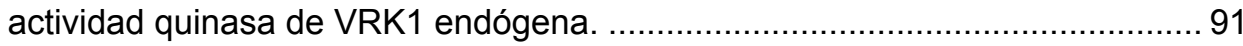

b) Efecto del inhibidor PD98059 sobre la actividad de VRK1 ............................... 92

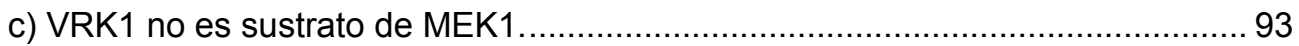

2.9.4. Comportamiento de la proteína VRK1 asociada al aparato de

Golgi tras el tratamiento con nocodazol, brefeldina A y ácido okadaico. 94

2.9.5. VRK1 es necesaria para la fragmentación del aparato de

Golgi inducida por MEK1 y Plk3.

2.10. Identificación de un posible sustrato de VRK1 en la ruta de

fragmentación del aparato de Golgi en división celular. 104

2.10.1. Identificación de VCP como proteína candidata a interaccionar con VRK1 mediante técnicas proteómicas. 
2.10.2. Validación de la interacción VRK1-VCP ............................................. 106

2.10.3. Análisis de la función de la interacción VRK1-VCP................................ 109

a) VRK1 no fosforila a VCP en un ensayo quinasa in vitro............................ 109

b) Efecto de VCP sobre la actividad de VRK1 in vitro. ................................... 110

c) El cofactor p47 tampoco es sustrato de VRK1 in vitro............................. 112

d) VRK1 precipitada de células es capaz de fosforilar a VCP. ....................... 112

e) La depleción de VRK1 evita la fosforilación de VCP en mitosis..................... 115

\section{Discusión}

1. Localización subcelular de VRK1 ............................................................. 119

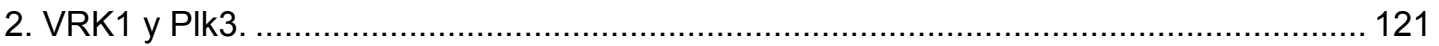

2.1. Análisis de la relación de VRK1 con la quinasa Plk3.............................. 121

2.2. Implicación de VRK1 en la dinámica del aparato de Golgi en

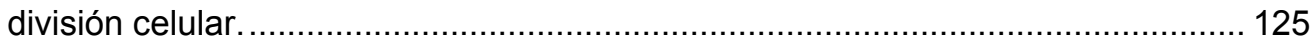

\section{Conclusiones ........}

\section{Materiales y Métodos}

1. Técnicas de manipulación de ácidos nucleicos.

1.1. Obtención de ADN codificante y generación de vectores recombinantes.

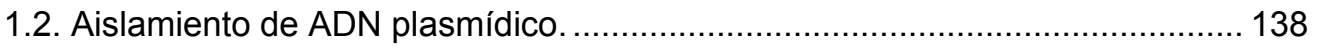

1.3. Determinación de la concentración de ácidos nucleicos. ............................... 138

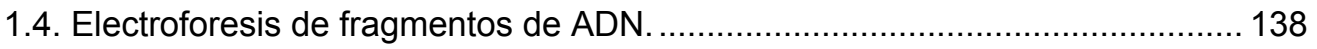

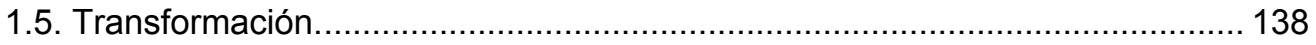

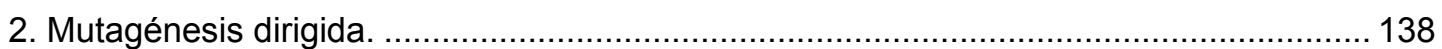

3. Purificación de proteínas de fusión. ............................................................ 139

3.1. Purificación de proteínas de fusión unidas a GST. ................................ 139

3.2. Purificación de proteínas de fusión unidas al epítopo $6 x H i s . . . \ldots \ldots \ldots \ldots \ldots \ldots \ldots . . . . . . . . . . . .140$

4. Tinción con azul de Coomassie. ................................................................ 140

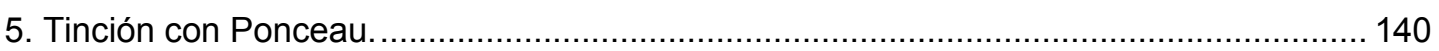

6. Ensayos de actividad quinasa in vitro. ...................................................... 141

6.1. Ensayos de actividad quinasa in vitro para VRK1................................ 141

6.2. Ensayos de actividad quinasa in vitro para las proteínas Plk....................... 141

6.3. Ensayos de actividad quinasa in vitro para MEK1 ............................... 142

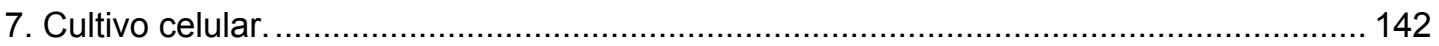

8. Transfecciones transitorias de ADN en células de mamífero en cultivo

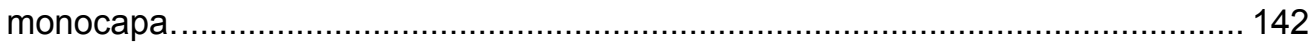

9. Transfecciones transitorias de ARNi en células de mamífero en cultivo monocapa. 
10. Electroforesis en geles SDS-PAGE e inmunoblot de extractos proteicos.

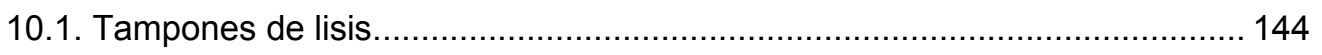

11. Precipitación de proteínas mediante tricloroacético. ............................................... 145

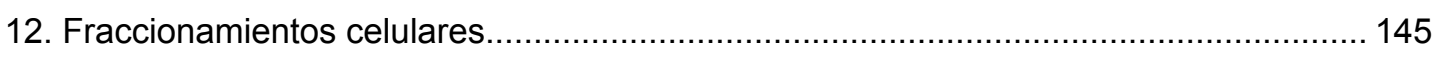

12.1. Aislamiento del aparato de Golgi de células de mamífero en cultivo monocapa según Balch (1984) por gradiente de sacarosa.................................. 145

12.2. Fraccionamiento membranas-citoplasma. ........................................... 146

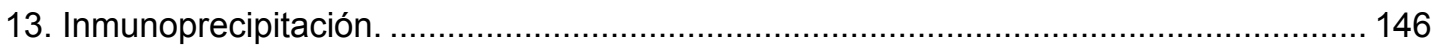

14. Ensayos de interacción por precipitación de proteínas de fusión

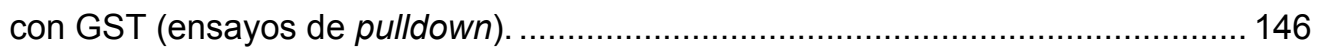

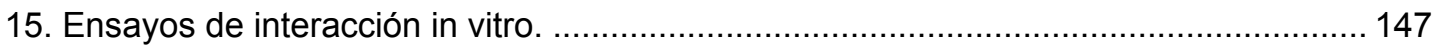

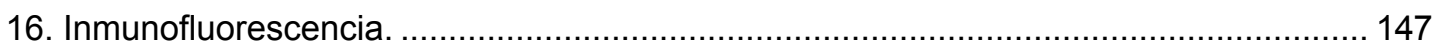

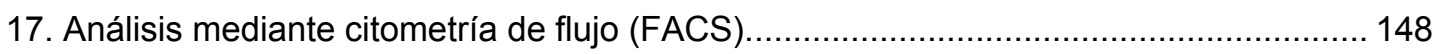

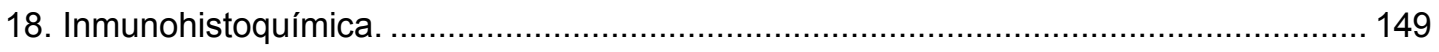

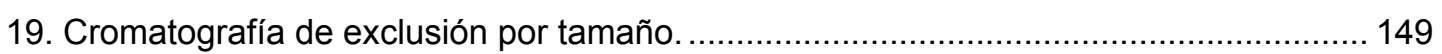

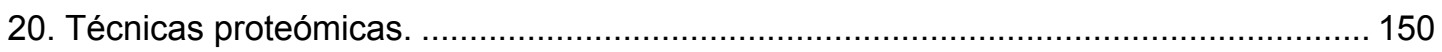

20.1. Puldown a gran escala para la purificación e identificación de proteínas asociadas a VRK1 ........................................................................ 150

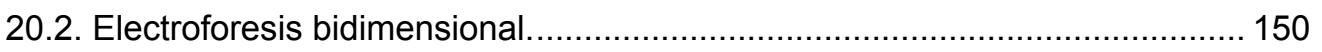

20.3. Digestión de los spots, determinación de las masas de los péptidos por MALDI-TOF e identificación con MASCOT.................................................... 151

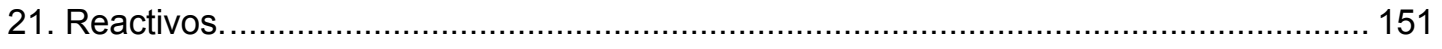

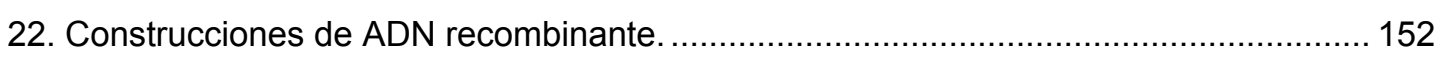

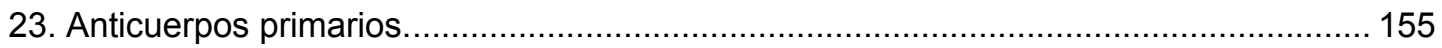

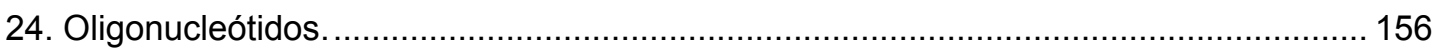

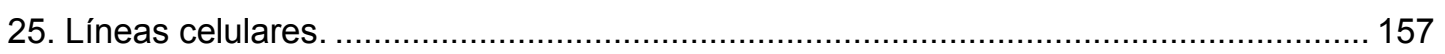

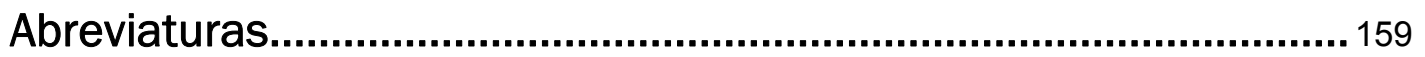

$\begin{array}{lr}\text { Bibliografía } & 167\end{array}$

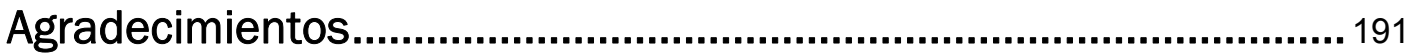






\section{Introducción}





\section{Señalización celular.}

La comunicación celular con el entorno se realiza a través de numerosas rutas de señalización, que reciben y procesan diferentes señales, no sólo del medio extracelular sino también de distintos microambientes intracelulares (Jordan et al., 2000). Estas vías no son lineales, sino que forman parte de una intrincada red que permite a la célula regular múltiples funciones de un modo muy preciso, tanto en el espacio como en el tiempo. Uno de los mecanismos básicos para la transmisión de la información es a través del ensamblaje regulado de complejos proteicos, que lleva a la activación o inhibición de actividades enzimáticas y, en último término, desencadena cambios en las funciones celulares $y$, por tanto, da lugar a una respuesta celular específica.

La fosforilación es una modificación postraduccional que juega un papel determinante en casi todos los aspectos de la célula, controlando propiedades como la actividad enzimática del sustrato, su localización subcelular, su interacción con otras moléculas o su degradación (Hanks et al., 1988; Hanks and Hunter, 1995; Yaffe and Elia, 2001; Johnson and Lapadat, 2002). Por tanto, las proteínas quinasas regulan rutas de señalización que median procesos como el metabolismo, la transcripción génica, la progresión del ciclo celular, la diferenciación, la organización del citoesqueleto, la apoptosis, la comunicación intercelular y las funciones neuronales y del sistema inmune. Por todo ello, la desregulación de proteínas quinasas es la causa de muchas enfermedades humanas (Manning et al., 2002).

\section{Plataformas de señalización en orgánulos subcelulares.}

Tradicionalmente, cuando se hablaba de señalización, los patrones de referencia eran la membrana plasmática, el citoplasma y el núcleo. Hoy en día esta visión es mucho más amplia y compleja. De hecho, la membrana plasmática ya no se considera un orgánulo homogéneo sino un denso mosaico de dominios de señalización (Laude and Prior, 2004) donde se localizan clusters de proteínas y lípidos que facilitan la señalización de determinadas rutas, concentrando sus componentes en microdominios. Como ejemplo de los orgánulos subcelulares como plataformas de señalización, se tomará la superfamilia de las MAP quinasas. Las MAP quinasas se 
caracterizan porque son activadas por señales mitogénicas (MAPK- Mitogen Activated Protein Kinases) y, dentro de estas, se encuentra la ruta de señalización de ERK (Extracelular signal-Related Kinase).

Las MAP quinasas son una superfamilia de serina/treonina quinasas que se activan por gran variedad de estímulos extracelulares como factores de crecimiento, hormonas, citoquinas y diferentes tipos de estrés. En mamíferos se expresan cuatro grupos de MAP quinasas: ERK1/2, JNK1/2/3 (c-Jun N-terminal Kinase), p38 $\alpha / \beta / \gamma / \delta$ y ERK5 (Chang and Karin, 2001; Johnson and Lapadat, 2002), que son activadas por MAP quinasa quinasas específicas (MAPKK). A su vez, cada MAP quinasa quinasa puede ser activada por más de una MAP quinasa quinasa quinasa (MAPKKK) (Figura 1).

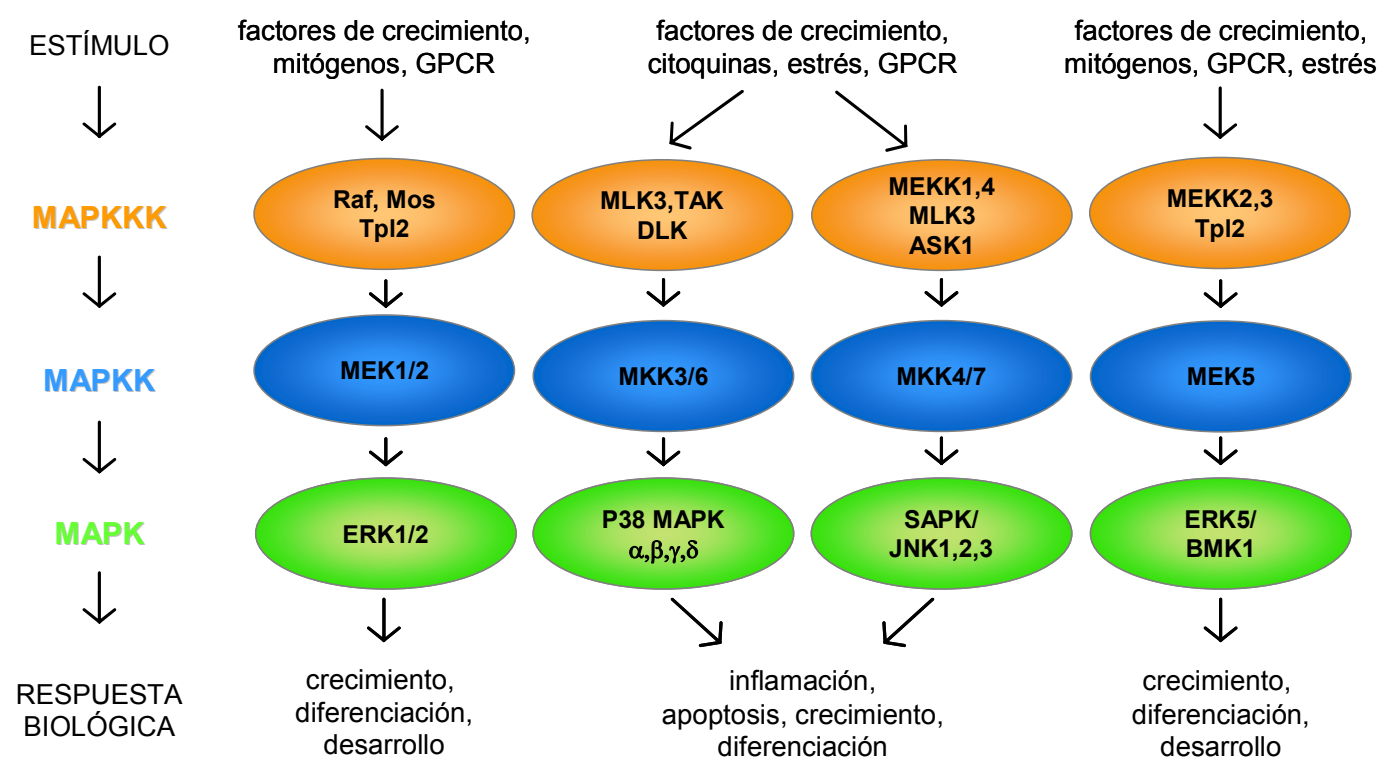

Figura 1. Distintas vías de señalización de las proteínas quinasas activadas por mitógenos.

La vía de transducción de señales mejor estudiada es la formada por el módulo Ras-Raf-MEK-ERK. Ras es activado por GEFs, que facilitan el intercambio de GDP por GTP (GEF- Guanine nucleotide Exchange Factor). Una vez activo, Ras-GTP, interacciona con diversas proteínas efectoras, entre ellas, Raf. A continuación, se activan MEK1/2 y, finalmente ERK1/2, todo ello por fosforilación.

En esta vía de señalización, muchos de sus componentes son regulados por compartimentación subcelular (Harding et al., 2005; Mor and Philips, 2006). Los compartimentos subcelulares de los que se va a citar algún ejemplo son los endosomas, el aparato de Golgi y el retículo endoplasmático. 


\subsection{Los endosomas.}

Las proteínas $\beta$-arrestinas participan en la señalización celular mediante el anclaje de complejos proteicos en vesículas de endocitosis. Esto ocurre, por ejemplo, con la $\beta$-arrestina-2 y el receptor de siete hélices AT1aR tras el estímulo con angiotensina. En este caso, se observa una activación de ERK2 en los endosomas tempranos. Así, la célula logra un pool de ERK2 activo en una zona muy concreta del citoplasma (Luttrell et al., 2001).

\subsection{El aparato de Golgi.}

Como ejemplo de la señalización en este orgánulo se encuentra la proteína transmembrana RTKG (Raf Kinase Trapping to Golgi) que se caracteriza por secuestrar a Raf-1 bloqueando su interacción con MEK/ERK. En este contexto RTKG no actúa como proteína de anclaje o scaffold, ya que solamente interacciona con Raf1, pero de este modo, inhibe la activación de la ruta por EGF (Epidermal Growth Factor) a través de una regulación espacial de la quinasa Raf-1 (Feng et al., 2007). Otro ejemplo es el de la proteína scaffold Sef, que localizada en el aparato de Golgi, sirve como plataforma de señalización de la ruta Ras/MAPK. Aquí, el secuestro de ERK por Sef bloquea la activación de sus dianas nucleares, como Elk-1, mientras permanece completamente activo para fosforilar sustratos citosólicos como RSK2 (Torii et al., 2004). Por último se citará un ejemplo sobre MEK1, proteína quinasa de la que existe una subpoblación en el aparato de Golgi. En este orgánulo, además de establecerse el módulo clásico MEK-ERK de señalización, parte de la señal que desencadena la fragmentación del aparato de Golgi iniciada por MEK1 en mitosis es transmitida por la quinasa PIk3 (Xie et al., 2004; Feinstein and Linstedt, 2007).

\subsection{El retículo endoplasmático.}

La GTPasa Ras se observa en su conformación activa (GTP-Ras) en diversos orgánulos subcelulares, entre ellos, el retículo endoplasmático. Se ha visto que la estimulación con EGF, en concreto de la isoforma H-Ras, la activa y desencadena la ruta de señalización MEK/ERK desde este compartimento (Chiu et al., 2002).

En resumen, tomando como referencia la ruta de ERK, se ha descrito cómo diferentes orgánulos subcelulares sirven de plataformas de señalización. De este modo, la célula logra especificidad en la señalización mediante una regulación espacial y temporal 
haciendo uso de los mismos complejos proteicos, parcial o completamente, en distintos compartimentos subcelulares.

\section{El quinoma humano: familias de quinasas VRK y Plk.}

Las proteínas quinasas son enzimas que catalizan la unión covalente de un grupo fosfato ( $\gamma$-fosfato del ATP) a residuos de serina, treonina o tirosina en proteínas celulares específicas. Las quinasas se encuentran en un estado activo o inactivo, regulado por diferentes mecanismos como son la fosforilación, la unión de otras subunidades y la interacción proteína-proteína. En humanos, la fosforilación en serina, treonina y tirosina es aproximadamente un $86,4 \%, 11,8 \%$ y $1,8 \%$ del total de fosforilaciones celulares, respectivamente (Olsen et al., 2006).

Tras la secuenciación del genoma humano, el grupo de Manning, catalogó las quinasas humanas en lo que se denominó el "quinoma humano", haciendo uso de las bases de datos genómicas disponibles, los ADNc y las EST (Expressed Sequence Tags) (Manning et al., 2002) (Figura 2A).

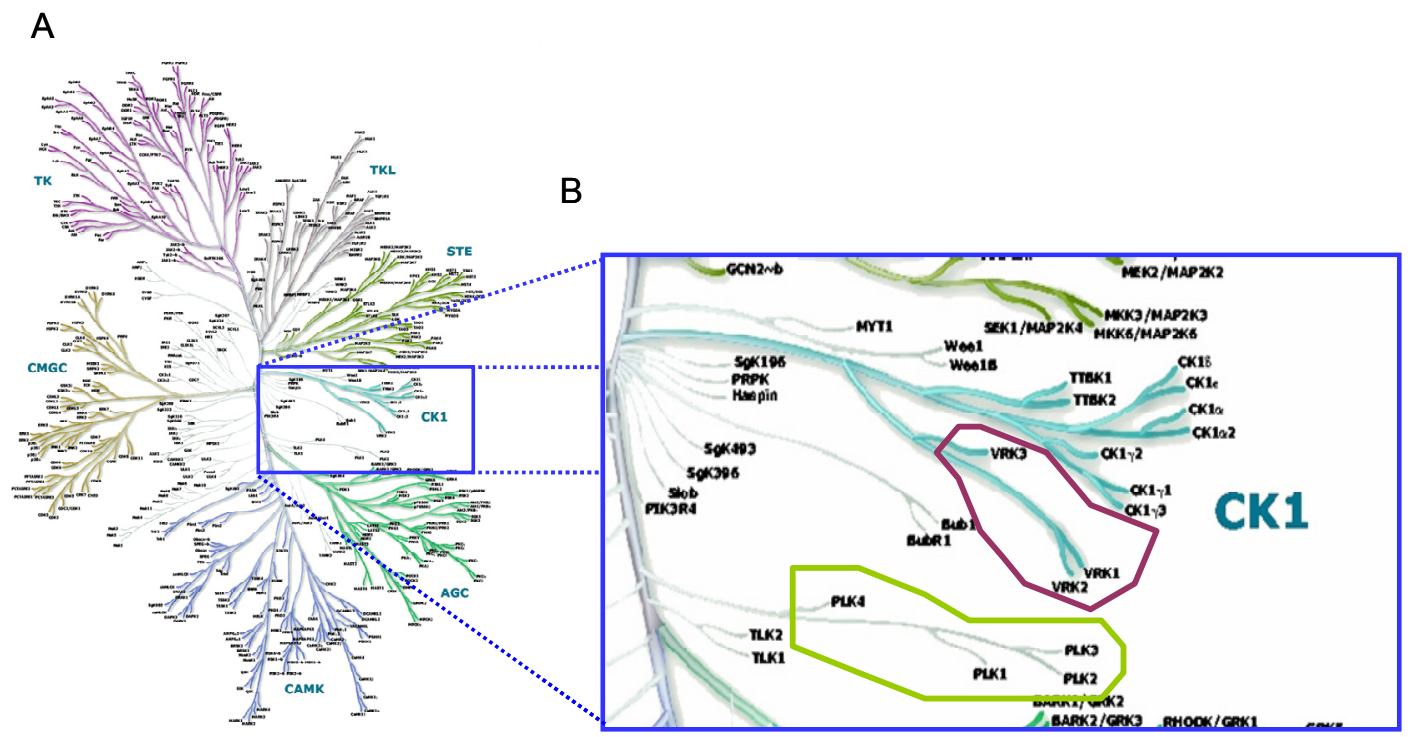

Figura 2. El quinoma humano. A) Clasificación en grupos de las familias de quinasas humanas (Manning et al., 2002). B) Las familias VRK y Plk dentro del quinoma humano. 
De este modo, se identificaron 518 proteínas quinasas clasificadas filogenéticamente en ocho grupos en función de la similitud de secuencia de sus dominios catalíticos. Cada grupo está dividido, a su vez, en varias subfamilias. Además de estos ocho grupos, existen varias familias de quinasas que no se encuadran en ningún grupo en concreto.

En esta clasificación, la familia de quinasas VRK (Vaccinia Related Kinase) (Figura 2B, en violeta) se localiza dentro del grupo de las caseínas quinasas de tipo I $(\mathrm{CKI})$ y formando parte de aquellas que no constituyen ningún grupo en concreto, se encuentra la familia de quinasas Plk (Polo like kinase) (Figura 2B, en verde). Estas dos familias de serina/treonina quinasas serán el eje central del presente trabajo y se hablará de ellas en mayor detalle en los siguientes apartados.

\subsection{La familia de quinasas humanas VRK.}

Las quinasas humanas VRK se encuentran dentro del grupo de las CKI, aunque solamente comparten homología en el dominio catalítico con estas (Lopez-Borges and Lazo, 2000) ya que divergieron pronto en la evolución.

La familia de quinasas humanas VRK consta de tres miembros: VRK1, VRK2 con dos isoformas (VRK2A y VRK2B) resultado de la maduración alternativa de su ARN mensajero (Blanco et al., 2006) y VRK3, catalíticamente inactiva debido a sustituciones en aminoácidos clave en su dominio quinasa (Nichols and Traktman, 2004; Scheeff et al., 2009). Las quinasas VRK1 y VRK2 fueron identificadas por su homología con la quinasa del virus Vaccinia B1 (Nezu et al., 1997), quinasa de expresión temprana en la infección viral e imprescindible para la replicación del ADN del virus (Banham and Smith, 1992; Lin et al., 1992). VRK1 tiene un 40\% de identidad sobre 305 aminoácidos de B1 y VRK2 un 38,7\% sobre 300 aminoácidos (Nezu et al., 1997). Además, la expresión ectópica de VRK1 es capaz de complementar parcialmente la deficiencia en la replicación del ADN viral que presenta el mutante sensible a temperatura ts 2 del virus Vaccinia (Boyle and Traktman, 2004). El tercer miembro de la familia, VRK3, fue identificado más tarde mediante la comparación de las secuencias de VRK1 y VRK2 con las bases de datos que había disponibles (Vega et al., 2003).

Existen ortólogos de las proteínas VRK humanas en otros organismos, aunque solamente hay tres miembros en los vertebrados como el ratón ( $M$. musculus), la rana (X. tropicalis) o el pez cebra (D. rerio). En invertebrados como moscas $(D$. melanogaster y $D$. pseudoobscura) y nematodos (C. elegans y C. briggsae) existe un 
único miembro (Figura 3) (Klerkx et al., 2009b). De hecho, esta situación podría ser un reflejo de cómo tuvo lugar la evolución de la familia VRK. Así, parece posible que un único gen ancestral de VRK se duplicara dos veces en el momento en que la rama de los vertebrados evolucionó, dejando a los invertebrados con un único gen y a los vertebrados con tres (Klerkx et al., 2009b). En levaduras no se han descrito ortólogos. No obstante hay proteínas que podrían ser los ancestros de la actual familia VRK, como es el caso de la proteína HRR25 de S. cerevisiae que codifica para una isoforma de caseína quinasa tipo I implicada en división celular y respuesta a daño al ADN (Hoekstra et al., 1991; Ho et al., 1997; Mehlgarten and Schaffrath, 2003).

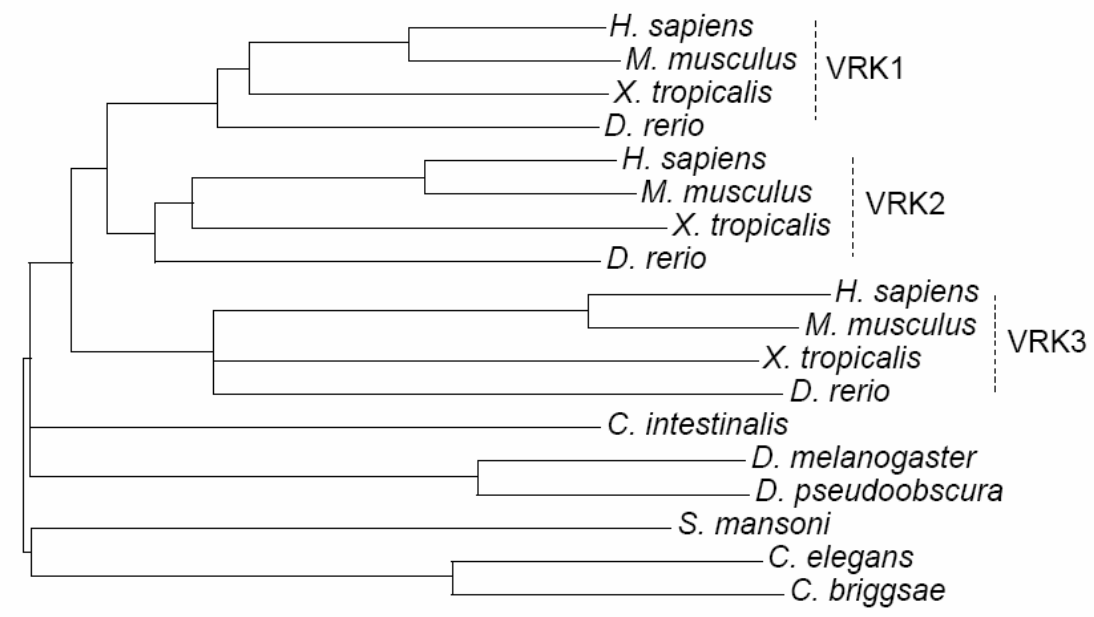

Figura 3. Relaciones filogenéticas entre las proteínas VRK humanas y los distintos ortólogos en otros organismos. Existen tres miembros en organismos vertebrados y un único miembro en organismos invertebrados (Klerkx et al., 2009b).

Existen algunos datos sobre las funciones de las proteínas VRK en los diferentes ortólogos debido en la mayoría de los casos a mutaciones o pérdida de las proteínas VRK.

En el nematodo Caenorhabditis elegans existe un ortólogo de VRK1 (CeVRK1) cuyo silenciamiento por ARN de interferencia da lugar a un fenotipo letal embrionario con gránulos citoplasmáticos grandes y problemas en la formación del pro-núcleo (Piano et al., 2000; Kamath et al., 2003). También se han descrito defectos en la fragmentación de la envuelta nuclear en mitosis y problemas en la formación de la envuelta y de los poros nucleares tras mitosis (Gorjanacz et al., 2007; Klerkx et al., 2009b), además de un fenotipo en adultos de crecimiento lento (Simmer et al., 2003). 
En el caso de la mosca Drosophila melanogaster (Morrison et al., 2000), la quinasa ortóloga se denomina NHK-1 (Nucleosomal Histone Kinase) y es capaz de fosforilar a la histona H2A en el residuo Thr119, cuya fosforilación es clave en la progresión del ciclo celular (Aihara et al., 2004). Además, mutaciones en el gen nhk-1 han revelado su participación en la correcta organización de los cromosomas en la meiosis de oocitos (Cullen et al., 2005; Ivanovska et al., 2005). El fenotipo de dichas mutaciones se caracteriza por la esterilidad de las moscas. También se han encontrado funciones en mitosis, ya que $\mathrm{NKH}-1$ es necesaria para la organización del huso mitótico (Cullen et al., 2005). De hecho, como otras quinasas implicadas en mitosis y/o meiosis, NHK-1 es regulada por fosforilación en diferentes fases de ambos procesos (Cullen et al., 2005).

La proteína ortóloga de ratón (Mus musculus) fue inicialmente denominada 51PK y se caracteriza por su alta autofosforilación en residuos de serina y por su localización nuclear (Zelko et al., 1998). En cuanto a sus funciones, se ha demostrado su importancia en proliferación celular y se ha confirmado su participación en gametogénesis, mediante ratones hipomórficos para VRK1 (Wiebe et al., 2009). Estos ratones, con un nivel de expresión de mVRK1 silvestre del $15 \%$, son viables, pero tanto las hembras como los machos son infértiles. Estos datos están en relación con otros resultados obtenidos para mVRK2 (Lu and Bishop, 2003). Así, los ratones gcd (germ cell deficient) son infértiles y presentan defectos muy severos en proliferación de células germinales. Estos ratones son el resultado de una mutación por inserción en la que se eliminaron los exones 2-11 de vrk2 y los exones 4-14 de pog (proliferation of germ cell) debido a que ambos genes solapan en el genoma aunque se transcriben en direcciones opuestas (Agoulnik et al., 2002). En un estudio posterior, se compararon estos ratones $\mathrm{gcd}$ con ratones $\mathrm{Pog}^{-/-}$y se determinó que el defecto severo en proliferación de células germinales debía ser por la ausencia de mVRK2 ya que en los ratones $\mathrm{Pog}^{-/-}$el defecto era menos drástico (Lu and Bishop, 2003).

\subsubsection{Motivos estructurales de las quinasas humanas VRK.}

Las quinasas humanas VRK1 y VRK2 (VRK2A y VRK2B) tienen un 44\% de homología en su secuencia, llegando al $53 \%$ si solamente se tienen en cuenta los dominios catalíticos (Nichols and Traktman, 2004). Tanto VRK1 como ambas isoformas de VRK2 tienen en su región amino terminal un dominio quinasa que incluye el sitio de unión al ATP y el dominio quinasa activo (Figura 4). La isoforma VRK2B es resultado de la maduración alternativa del ARN mensajero de VRK2, que da lugar a una proteína 
de 397 aminoácidos. VRK2B es exactamente igual en secuencia a VRK2A hasta el aminoácido 394. La diferencia está en los últimos tres aminoácidos que son reemplazados por valina-glutámico-alanina (VEA). Por otro lado, la isoforma VRK2A se caracteriza por presentar en su extremo carboxilo una región transmembrana $(R T)$. De este modo, la isoforma VRK2A se encuentra anclada a membranas de retículo endoplasmático, envuelta nuclear y mitocondrias, mientras que VRK2B se localiza en el núcleo y en el citoplasma (Nichols and Traktman, 2004; Blanco et al., 2006).

La quinasa VRK1 presenta en su extremo carboxilo una secuencia de localización nuclear (NLS) y una posible secuencia de exportación nuclear (NES). En este extremo también tiene el motivo BAB (BAB-Basic-Acid-Basic), que se caracteriza por tener una región de aminoácidos ácidos flanqueada por una región de aminoácidos básicos (Aihara et al., 2004).
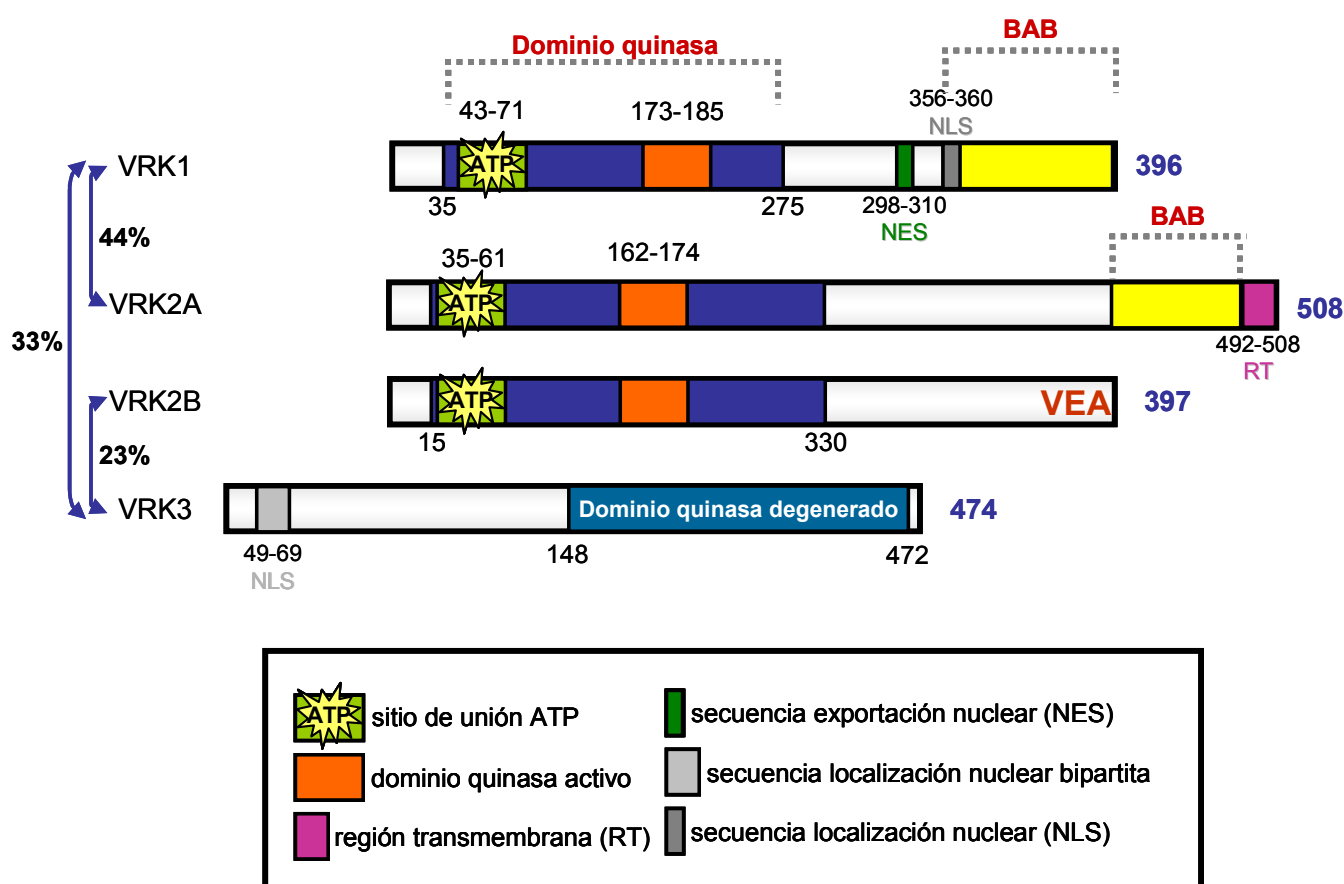

Figura 4. Representación esquemática de la estructura de las quinasas humanas de la familia VRK alineadas según identidad de secuencia de aminoácidos.

El motivo BAB también ha sido descrito en organismos ortólogos de las proteínas VRK humanas. Así, la quinasa VRK en D. melanogaster (NHK-1) tiene un motivo BAB en su extremo carboxilo, la quinasa VRK en $C$. elegans (CeVRK1) tiene tres motivos $B A B$ en su extremo carboxilo y la quinasa VRK2 de $X$. laevis tiene dos motivos BAB. La isoforma humana VRK2A tiene un doble motivo BAB solapado en su extremo carboxilo, a diferencia de la isoforma VRK2B, que lo tiene truncado. 
Se desconoce la función del motivo $B A B$, pero el hecho de que se haya conservado en la evolución, y de que sea característico de las quinasas VRK, hace pensar que tiene una función importante y común en todas ellas. Así, se piensa que la región carboxilo de las proteínas VRK tiene una función reguladora (Lopez-Borges and Lazo, 2000).

Por último, la pseudoquinasa VRK3 es el miembro más divergente de la familia. Posee una homología de un $33 \%$ con VRK1 y solamente de un $23 \%$ con VRK2. Esta proteína se caracteriza por una secuencia bipartita de localización nuclear (NLS) en su extremo amino y un dominio quinasa degenerado en su extremo carboxilo. Carece, por tanto, de actividad quinasa debido a sustituciones en aminoácidos clave en su dominio catalítico (Nichols and Traktman, 2004; Scheeff et al., 2009).

\subsubsection{Estructura del dominio catalítico de la familia VRK.}

La estructura tridimensional del dominio catalítico de VRK2 (aminoácidos 15-330) y VRK3 (aminoácidos 148-472) revela una conformación bien estructurada y activa (Scheeff et al., 2009). La fosforilación directa en el loop de activación es el método habitual para regular la actividad de una quinasa, aunque existen casos en los que no tiene lugar dicha fosforilación y la quinasa es activa. Este es el caso de las proteínas VRK, que consiguen una conformación activa debido a una $\alpha$-hélice adicional $(\alpha C 4)$ en el segmento de activación, lo que sugiere que todas las quinasas VRK son constitutivamente activas (Scheeff et al., 2009).

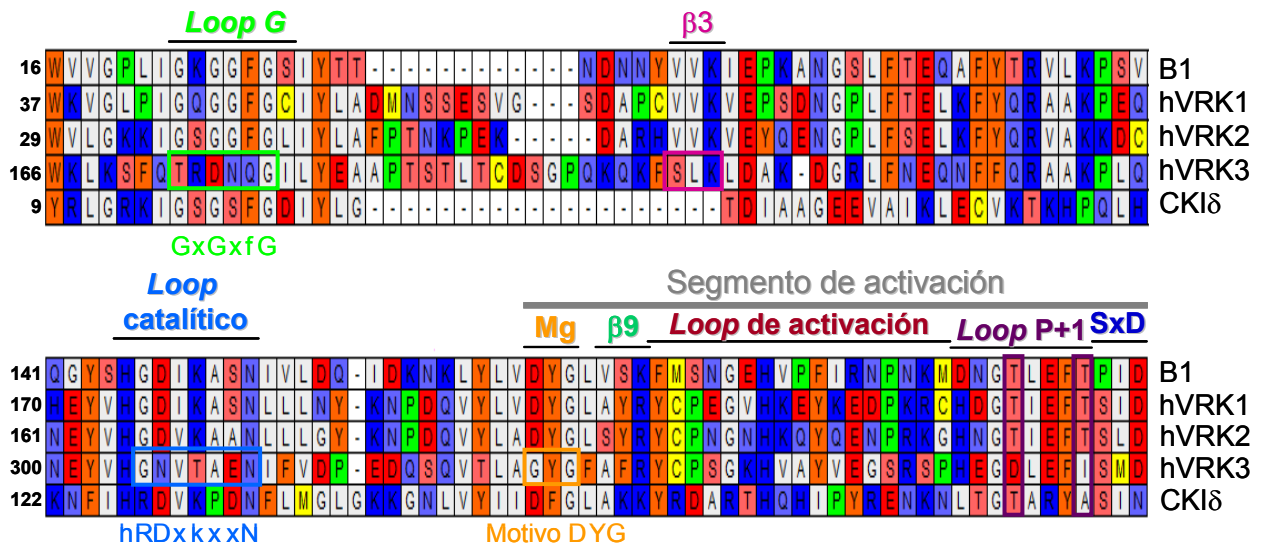

Figura 5. Alineamiento del sitio de unión de ATP y dominio quinasa de la familia VRK. Se llevó a cabo un alineamiento de las secuencias de aminoácidos de las proteínas quinasas B1, hVRK1, hVRK2, hVRK3 y CKI $\delta$ mediante el programa Accelrys DS Gene 1.5, utilizando ClustalW. 
La pseudoquinasa VRK3 contiene múltiples cambios en su secuencia que son necesarios para la actividad quinasa. Así, tiene sustituciones importantes en el loop G (GxGxfG), el loop catalítico, también denominado RD pocket (hRDxkxxN), y el motivo DYG (dominio de unión a magnesio) (Figura 5, hVRK3). La función del loop G es la de situar el ATP correctamente y, en este motivo, las glicinas (G) son imprescindibles. En VRK3 estas glicinas se han sustituido por aminoácidos de mayor tamaño. Además, los dos aminoácidos valina $(\mathrm{V})$ que preceden a una lisina en $\beta 3(\mathbf{V V K})$ también han sido reemplazados en VRK3, en este caso, por serina y leucina (SLK) (Nichols and Traktman, 2004). El loop catalítico se encarga de orientar el grupo hidroxilo del sustrato y, en este dominio, el aminoácido aspartato (D) es sustituido en VRK3 por asparragina (N). Por último, el aspartato del motivo DYG (DYG), que es necesario para la transferencia del fosfato del ATP, ha sido sustituido en VRK3 por una glicina (GYG). La sustitución de los aminoácidos clave para la correcta colocación del ATP, la orientación del sustrato y la transferencia del fosfato del ATP hacen que VRK3 carezca de actividad quinasa. Así, VRK3, al igual que otras pseudoquinasas, podría tener función de proteína de anclaje o scaffold (Boudeau et al., 2006).

El segmento de activación es una región de 20-40 aminoácidos situada en el dominio catalítico de las proteínas quinasas. Muchas quinasas son activadas mediante fosforilación o autofosforilación de residuos clave en el segmento de activación (Nolen et al., 2004). En el caso de las proteínas VRK, no se conoce la función del segmento de activación con respecto a la regulación de la actividad quinasa, pero existen ciertas características que son propias de ellas. Así, el motivo DfG cambia a DYG y el motivo APE cambia a SxD en las quinasas VRK (Figura 5) (Nichols and Traktman, 2004; Scheeff et al., 2009). Además, las proteínas VRK con actividad quinasa conservan dos treoninas $(\mathrm{T})$ en el loop $\mathrm{P}+1$ lo que sugiere que estas podrían ser importantes para la actividad de las quinasas (Scheeff et al., 2009).

\subsubsection{La quinasa humana VRK1.}

El gen de vrk1 se localiza en el cromosoma 14q32 y codifica para una proteína de 396 aminoácidos (Nezu et al., 1997). La quinasa humana VRK1 se caracteriza por presentar una alta actividad de autofosforilación en residuos serina y treonina, propiedad que comparte con las caseínas quinasas. A diferencia de las quinasas CKI, la quinasa VRK1 fosforila tanto proteínas ácidas (fosvitina y caseína) como básicas (histona 2b) (Lopez-Borges and Lazo, 2000). En cuanto a sus propiedades enzimáticas, VRK1 es activa en presencia de los cationes $\mathrm{Mn}^{2+}, \mathrm{Mg}^{2+}$ y $\mathrm{Zn}^{2+}$ y puede 
utilizar como donador de fosfato tanto el ATP como el GTP in vitro, aunque este último con menor afinidad (Barcia et al., 2002).

\section{a) Localización subcelular de VRK1.}

VRK1 fue inicialmente descrita como una proteína nuclear (Lopez-Borges and Lazo, 2000) aunque estudios posteriores también la han observado en el núcleo excluida o no del nucleolo (Vega et al., 2004; Andersen et al., 2005) y en el citoplasma asociada al aparato de Golgi (Valbuena et al., 2007a; Lopez-Sanchez et al., 2009). Este último dato será parte de la presente tesis. Por último, también se ha encontrado que la quinasa VRK1 se localiza en el nucleoplasma asociada a la cromatina (Shiio et al., 2003; Kang et al., 2007) e incluso se ha detectado en la cromatina asociada a complejos implicados en el inicio de la transcripción (Guermah et al., 2006).

Esta gran variedad de subpoblaciones de VRK1 implica una precisa regulación de la quinasa y una amplia variedad de funciones celulares.

\section{b) Sustratos de VRK1: factores de transcripción.}

La mayoría de los sustratos conocidos para VRK1 son factores de transcripción. Entre ellos están ATF-2 (Sevilla et al., 2004b), c-Jun (Sevilla et al., 2004a), CREB (Kang et al., 2008) y p53 (Lopez-Borges and Lazo, 2000). Además, también son sustratos la proteína BAF (Barrier to Autointegration Factor) (Nichols et al., 2006) y la histona H3 (Kang et al., 2007). De estos dos últimos se hablará en el próximo apartado.

El factor de transcripción ATF-2 (Activating Transcription Factor-2) pertenece a la familia de proteínas ATF/CREB (Cyclic AMP Response Element), implicadas en respuesta a diferentes tipos de estrés celular. Se conocen múltiples quinasas capaces de fosforilarlo como son las MAP quinasas p38, JNK y ERK (Morton et al., 2004), además de la quinasa PKA (Protein Kinase $A$ ) y la quinasa CaMK-IV (Calmodulin Kinase IV). Una vez activo forma homodímeros o heterodímeros, que se unen específicamente a secuencias de su promotor diana. La quinasa VRK1 fosforila a ATF2 en su región amino terminal (residuos Thr73 y Ser62) lo que induce su acumulación y activación transcripcional (Sevilla et al., 2004b).

En cuanto a c-Jun, se trata de un factor transcripción regulado en respuesta a citoquinas, factores de crecimiento y estrés oxidativo, que se activa por fosforilación en su extremo amino. Las quinasas descritas en su regulación son ERK y JNK (Chang and Karin, 2001). VRK1 fosforila a c-Jun en los residuos serina 63 y serina 73 , lo que 
induce su acumulación y activación transcripcional. Estos residuos son los mismos que JNK fosforila, por lo que existe un efecto cooperativo de ambas quinasas en la activación de c-Jun (Sevilla et al., 2004a).

Por último, se hablará de p53. De este factor de transcripción existe una mayor cantidad de datos respecto a VRK1. El supresor de tumores p53 se ha denominado el "guardián del genoma" debido a su importancia en el mantenimiento de la homeostasis celular (Levine, 1997). El factor de transcripción p53 se encuentra en la célula en unos niveles basales, estrictamente controlados, y solamente se produce un aumento en sus niveles en respuesta a distintos tipos de estrés. Para que se produzca la acumulación, estabilización y activación de p53 tienen lugar modificaciones postraduccionales como fosforilaciones y acetilaciones. Ya en el núcleo, se une a sus genes diana específicos y se desencadenan diferentes respuestas como parada del ciclo celular, reparación del ADN o apoptosis entre otras. Dentro de estos genes están sus reguladores negativos, como Mdm2. Así, una vez producida la respuesta biológica inducida por p53, este es enviado a degradación por ubiquitinación y se reestablecen sus niveles basales.

La quinasa VRK1 fosforila a p53 en treonina 18 (Lopez-Borges and Lazo, 2000), residuo clave en la interacción de p53 con su regulador negativo Mdm2 (Kussie et al., 1996; Schon et al., 2002). Esta fosforilación impide la interacción de p53 con Mdm2 y promueve el reclutamiento de p300 y la estabilización de p53 (Vega et al., 2004). La activación de p53 induce a su vez la expresión de un gen, hasta el momento desconocido, que promueve la degradación de VRK1 (su activador) por la vía lisosomal (Valbuena et al., 2006). De este modo, se establece un circuito de autorregulación VRK1-p53. Además, se ha determinado que en carcinoma de pulmón con mutaciones que inactivan transcripcionalmente a p53, los niveles de VRK1 son muy elevados (Valbuena et al., 2007b). Por último, el cofactor p300, que también participa en la activación de p53 (por acetilación), protege a VRK1 de la degradación inducida por p53, cambiando la especificidad de sus dianas de transcripción (Valbuena et al., 2008a).

En cuanto al papel biológico de la relación VRK1-p53, se ha propuesto que la activación de p53 por VRK1, y posterior degradación, funcionan en condiciones de crecimiento normal para mantener los niveles basales de activación de p53. Bajo una situación de estrés, se provoca un cambio en el balance VRK1-p53 lo que resulta en una acumulación y respuesta celular dependiente de p53 (Vega et al., 2004). 


\section{c) Implicación de VRK1 en proliferación y división celular.}

Existen diversos datos que sugieren varios mecanismos por los cuales VRK1 está implicada en el control de la progresión del ciclo celular (Figura 6).

En primer lugar, el ARN mensajero de VRK1 se expresa en todos los tejidos que han sido analizados, siendo sus niveles de expresión especialmente altos en tejidos con alta tasa de proliferación celular como hígado fetal, testículos y timo fetal. Además, también se han encontrado altos niveles de expresión en líneas celulares tumorales (Nezu et al., 1997) y, en el desarrollo embrionario de ratón, la mayor expresión de VRK1 coincide con la expansión de las células hematopoyéticas (Vega et al., 2003). Dentro de los propios tejidos, se ha determinado que su expresión coincide con la zona de mayor proliferación tanto en epitelios normales como tumorales. Así, la expresión de VRK1 en la capa basal es máxima y va disminuyendo progresivamente a medida que las células epiteliales se van diferenciando (Santos et al., 2006; Valbuena et al., 2008b). De hecho, su expresión correlaciona en carcinoma de cabeza y cuello con marcadores de proliferación (antígeno Ki67, CDK2, CDK6, survivina, Cdc2 y ciclina A) y presenta una correlación inversa con $\mathrm{p} 16$, un inhibidor de ciclo celular. En carcinoma de pulmón, VRK1 también correlaciona positivamente con marcadores de proliferación (Valbuena et al., 2007b).

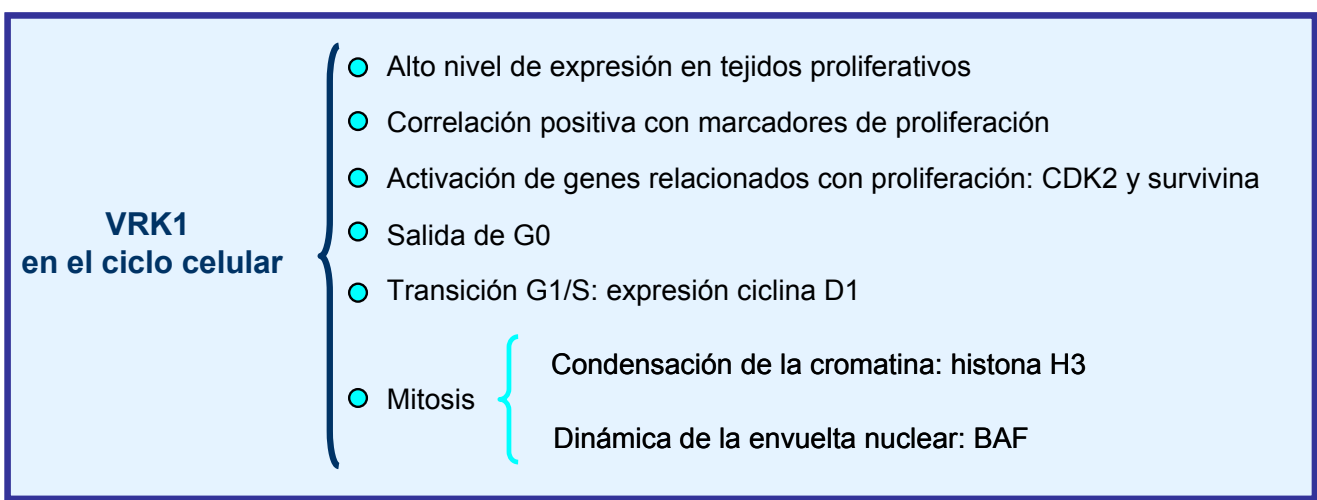

Figura 6. VRK1 en el ciclo celular. Se resumen los distintos datos que relacionan a la quinasa VRK1 con funciones en la progresión del ciclo celular y la división celular.

Además, la quinasa VRK1 induce la activación transcripcional de genes relacionados con proliferación como CDK2 y survivina (Santos et al., 2006). También se ha descrito que E2F1 (factor de transcripción esencial en la fase G1/S) regula positivamente la expresión de VRK1, mientras que p16 y Rb no fosforilado la reducen 
(Vernell et al., 2003; Santos et al., 2006). De hecho, se predice un sitio de unión de E2F en el promotor de VRK1 (Semizarov et al., 2004).

Asimismo, se han encontrado funciones de VRK1 en distintas fases del ciclo celular. Se ha determinado que VRK1 es necesaria en la transición G0/G1 ya que la retirada de suero de células en cultivo, que provoca una parada del ciclo celular en la fase G0, induce una disminución en los niveles del ARN mensajero de VRK1 y, por tanto, en los niveles de proteína. Además, la expresión del promotor de la quinasa VRK1 también se regula por suero. Así, la activación del gen de VRK1 es temprana y paralela a otros genes de expresión temprana como myc y fos (Valbuena et al., 2008b).

VRK1 también participa en la transición G1/S del ciclo celular induciendo la expresión de la ciclina D1 (Kang et al., 2008). La ciclina D1 es la primera que se induce cuando células en G0 se estimulan para entrar en ciclo celular (Sherr, 1994). Se ha descrito que VRK1 fosforila al factor de transcripción CREB en la serina 133, residuo implicado en la activación de CREB (Johannessen et al., 2004). Esta fosforilación promueve la unión de CREB al elemento de respuesta a AMP cíclico (CRE) en el promotor del gen de la ciclina D1, activando la expresión de esta. Por lo tanto, la quinasa VRK1 promueve la progresión de la fase $\mathrm{G} 1$ a $\mathrm{S}$ a través de la inducción de la ciclina D1 (Kang et al., 2008).

Se ha observado que una de las funciones de VRK1 en mitosis es la fosforilación de la histona $\mathrm{H} 3$ en los residuos treonina 3 y serina 10 (Kang et al., 2007). Las modificaciones postraduccionales en las colas de las histonas son esenciales para procesos como la transcripción y la mitosis (Berger, 2007). La fosforilación de la histona H3 (Ser10) en mitosis es responsable de la condensación de la cromatina, lo que es crítico para la correcta compactación de los cromosomas (Johansen and Johansen, 2006). Esta fosforilación en serina 10, además de observarse en mitosis, también se detecta en interfase. En este caso, en fracciones muy reducidas de nucleosomas y relacionada con la transcripción de promotores específicos (Berger, 2007). Por lo tanto, VRK1 participa en la dinámica de la cromatina en mitosis, papel también asociado a su quinasa ortóloga en $D$. melanogaster NHK-1, que fosforila a la histona H2A durante mitosis (Kang et al., 2008).

Por último, VRK1 participa en la dinámica de la envuelta nuclear en mitosis mediante la fosforilación de BAF en la serina $4 \mathrm{y}$, en menor medida, en las treoninas 2 y 3 (Nichols et al., 2006). La proteína BAF se encarga del anclaje de la cromatina a la envuelta nuclear en interfase. En mitosis, se localiza de un modo difuso y tiene una 
función esencial al final de anafase en el ensamblaje de la envuelta nuclear (Haraguchi et al., 2001). Se propone que la fosforilación de BAF por VRK1 ocurre en profase e induce la liberación de BAF de la cromatina, permitiendo la condensación de esta y la fragmentación de la envuelta nuclear. Al final de telofase, BAF se desfosforila, permitiendo de nuevo el ensamblaje de la envuelta y la organización de la cromatina. Esta función se conserva en organismos ortólogos de VRK1. Así, la quinasa VRK de C. elegans fosforila a BAF y tiene un papel fundamental en el ensamblaje de la envuelta tras mitosis (Gorjanacz et al., 2007) y NHK-1 fosforila a BAF en relación a la formación del cariosoma en oocitos (Lancaster et al., 2007). Por ultimo, B1 también fosforila a BAF, para favorecer la infección viral (Wiebe and Traktman, 2007).

\section{d) Regulación de la función y actividad de VRK1.}

Hasta el momento los datos que existen en cuanto a la regulación de la quinasa VRK1 son principalmente acerca de su expresión. También se conocen diversos sustratos de la quinasa como, por ejemplo, p53, ATF-2, c-Jun, BAF, CREB e histona H3. De hecho, con casi todos ellos la quinasa interacciona. Sin embargo, poco es conocido en cuanto a reguladores de su localización, función y actividad. La quinasa VRK1 posee una alta tasa de autofosforilación en residuos de serina y treonina (Barcia et al., 2002). Muchos de estos residuos se localizan en su extremo carboxilo, fuera del dominio quinasa, aunque solamente dos parecen aportar algo de información (Thr355 y Thr390), ya que mutantes no fosforilables en esos residuos provocan cambios en el patrón de péptidos obtenidos en ensayos quinasas in vitro. Además, sus características estructurales indican que la región carboxilo es flexible y se predice un posible papel de esta región en la regulación de la quinasa (Lopez-Borges and Lazo, 2000) ya sea por modificaciones postraduccionales o mediante interacción. De hecho, recientemente se han descrito dos reguladores de VRK1. Uno de ellos, Ran, regula la actividad quinasa de VRK1 in vitro por interacción (Sanz-Garcia et al., 2008), y el otro, Plk3 (Polo like kinase 3), fosforila a VRK1 activándola (Lopez-Sanchez et al., 2009). La relación establecida entre VRK1 y Plk3 será el tema central a desarrollar en la presente tesis.

La GTPasa Ran (Ras-related Ran GTPase) interacciona con VRK1 (también con los otros miembros de la familia VRK) y regula negativamente su autofosforilación y la fosforilación de su sustrato histona H3 in vitro (Sanz-Garcia et al., 2008). Esta inhibición de la actividad sólo tiene lugar con Ran-GDP y, aunque la función biológica de la interacción se desconoce, se piensa que la asociación de VRK1 con Ran en el núcleo puede ser importante en la regulación de factores de transcripción. 
En cuanto a otra posible regulación por fosforilación, la treonina 378 de VRK1 fue identificada como posible diana de las quinasas ATM (Ataxia Telangiectasia Mutated) y ATR (ATM and Rad3-related) en respuesta al daño por luz UV (Stokes et al., 2007).

e) VRK1 y su relación con enfermedades humanas.

Existen evidencias de que VRK1 se pueda considerar un marcador pronóstico en cáncer de mama. En los estudios de Fournier y Martin (Fournier et al., 2006; Martin et al., 2008), la selección de marcadores pronósticos se realizó utilizando un modelo de cultivo en 3D de células epiteliales mamarias no malignas. Se identificaron 22 genes en un primer estudio y se validaron más tarde comparando su expresión en microarrays con tres bases de datos distintas (Fournier et al., 2006). La quinasa VRK1 fue uno de los genes identificados. Así, un nivel elevado de VRK1 fue asociado con un mal pronóstico en tumores de mama $\mathrm{ER}^{+}$(Estrogen Receptor) (Martin et al., 2008).

En cuanto a la existencia de alguna enfermedad relacionada directamente con un defecto o mutación en VRK1, recientemente se ha descrito la primera mutación en su gen que tiene como consecuencia una atrofia muscular espinal con hipoplasia pontocerebelosa (SMA-PCH). La mutación R358X en la secuencia de localización nuclear provoca un codón de parada, que es la causa de la enfermedad. La identificación de VRK1 en relación con esta enfermedad implica un posible papel de la quinasa en el desarrollo y mantenimiento del sistema nervioso (Renbaum et al., 2009).

\subsubsection{Las quinasas humanas VRK2A y VRK2B.}

El gen vrk2 se localiza en el cromosoma 2p16, contiene 13 exones y codifica para dos isoformas denominadas VRK2A y VRK2B. La isoforma VRK2A se caracteriza por tener una secuencia hidrofóbica que la ancla a membranas del retículo endoplasmático, mitocondrias y núcleo. Por su parte, la isoforma VRK2B es más corta, carece de dicha secuencia y su localización es citoplasmática y nuclear (Nichols and Traktman, 2004; Blanco et al., 2006).

En cuanto a los sustratos conocidos para VRK2, existe cierta redundancia con VRK1. De hecho, tanto VRK2A como VRK2B fosforilan in vitro al factor de transcripción p53 en treonina 18. Sin embargo, solamente VRK2B induce su estabilización y activación transcripcional in vivo (Blanco et al., 2006). VRK2 también fosforila a BAF al igual que VRK1 (Nichols et al., 2006). Además, ambas isoformas se han descrito como moduladores de respuesta a estrés desencadenado por 
interleuquina-1 $\beta$ (Blanco et al., 2008) e hipoxia (Blanco et al., 2007) a través de la ruta de MAP quinasas TAK1-MKK7-JNK. Este módulo de señalización es ensamblado por la proteína scaffold JIP1 (JNK Interacting Protein 1), que recluta a JNK para ser fosforilada que, a su vez, fosforila a c-Jun y este activa la transcripción de AP1. Ambas isoformas interaccionan establemente con JIP1, TAK1 y MKK7, impidiendo la unión al complejo de JNK y evitando la activación de c-Jun (Blanco et al., 2007; Blanco et al., 2008).

\subsubsection{La pseudoquinasa humana VRK3.}

El gen vrk3 se localiza en el cromosoma 19q13 y codifica para una proteína de 472 aminoácidos. Este miembro de la familia VRK se caracteriza por ser catalíticamente inactivo, aspecto que ya se describió en detalle en el apartado 3.1.2. En cuanto a su función, se piensa que actúa como proteína scaffold, participando en el ensamblaje de complejos multiproteicos (Boudeau et al., 2006; Scheeff et al., 2009). De hecho, la única función hasta el momento estudiada es su participación en la regulación de ERK en el núcleo (Kang and Kim, 2006, 2008). VRK3 interacciona con una fosfatasa de MAP quinasas denominada VHR (Vaccinia H1 Related) y, como consecuencia, VHR se activa desfosforilando a ERK e inhibiendo la ruta. Además, se ha descrito que el propio ERK, una vez activo, induce la expresión de VRK3. De este modo, se establece una retroalimentación negativa de la ruta de ERK activada por VRK3 (Kang and Kim, 2006). VRK3 establece un complejo ternario con ERK y VHR, creando un sitio de interacción para ERK, ya que VHR carece del dominio de unión de MAP quinasas característico de otras fosfatasas de la familia (Kang and Kim, 2008).

\subsection{La familia de quinasas humanas PIk.}

Las proteínas Plk (Polo like kinase) son una familia de serina/treonina quinasas con funciones clave en la progresión del ciclo celular y en respuesta a daño al ADN (Barr et al., 2004).

Estas quinasas conservan una fuerte homología entre especies tanto a nivel estructural como funcional, tomando su nombre del gen polo de D. melanogaster. Este gen codifica una proteína necesaria para una correcta mitosis y segregación de los cromosomas (Sunkel and Glover, 1988; Llamazares et al., 1991).

Existen ortólogos de la proteína Polo de la mosca en otros organismos, aunque solamente las levaduras S. cerevisiae (Cdc5) (Kitada et al., 1993) y S. pombe (Plo1) 
(Ohkura et al., 1995) tienen un único miembro, ya que en humanos, ratón, rana y nematodo hay como mínimo tres, denominados Plk1/Plx1/Plc1, Plk2/PIx2/Plc2 y Plk3/Plx3/PIc3, respectivamente. Más tarde, se incluyó dentro de la familia Plk un cuarto miembro denominado Sak o Plk4 (Fode et al., 1994).

\subsubsection{Estructura y regulación de las quinasas PIk.}

En humanos existen cuatro proteínas Plk: Plk1, Plk2, Plk3 y Plk4. De todos los miembros de la familia, la quinasa Plk1 es la mejor estudiada y de la que existen más datos.

Todas las quinasas Plk tienen una estructura similar, con un dominio quinasa en la zona amino y un dominio Polo Box (PBD) en la región carboxilo (Figura 7). El dominio quinasa se caracteriza por un sitio típico de unión al ATP y una treonina altamente conservada que es clave para la activación de la quinasa (Nolen et al., 2004). En la proteína PIk3, la treonina es la 219 (localizada en el loop de activación). El dominio Polo Box está formado por dos secuencias Polo Box, la región entre ellas y la zona de la proteína hasta el dominio quinasa en Plk1, Plk2 y Plk3 (Figura 7). Sin embargo, Plk4 presenta solamente un dominio Polo Box que, en su caso, contribuye en la formación de homodímeros (Leung et al., 2002). Se ha propuesto que este dominio, característico de la familia Plk, tiene un papel clave en la regulación de la actividad, función y localización subcelular de estas quinasas (Nigg, 1998; Jang et al., 2002a). Así, mutaciones en residuos clave del domonio Polo Box de Plk1 provocan la deslocalización de la quinasa de estructuras mitóticas (Lee et al., 1998; Seong et al., 2002) y, en el caso de Plk3, se ha descrito que este dominio determina su correcta localización en los centrosomas y en los polos del huso mitótico (Jiang et al., 2006).

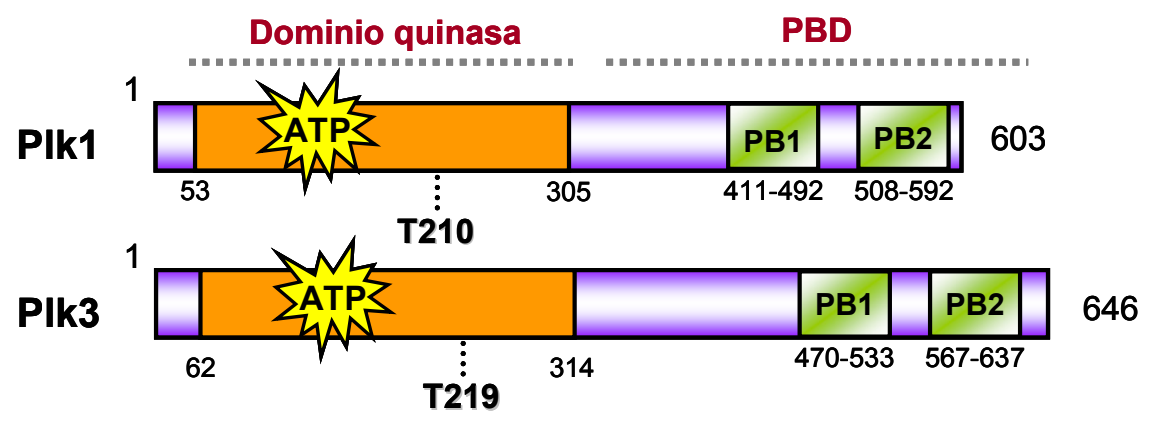

Figura 7. Representación esquemática de la estructura de la quinasas humanas Plk1 y PIk3. Se indica la posición del dominio quinasa y del dominio Polo Box (PBD) formado por dos Polo Box (PB1 y PB2), la región entre ellos y la zona de la proteína hasta el dominio quinasa. 
Por otro lado, según unos estudios realizados por Yaffe y colaboradores (Elia et al., 2003a; Elia et al., 2003b), el dominio Polo Box de Plk1 funciona como un módulo de unión a serina/treonina fosforiladas. Este descubrimiento no es ninguna novedad, ya que está demostrado el ensamblaje de complejos específicos de señalización dependientes de fosforilación (Pawson and Nash, 2003). La secuencia reconocida por el motivo Polo Box es Ser-[pSer/pThr]-[Pro/X], lo que sugiere que Cdks, MAP quinasas u otras quinasas mitóticas pueden producir una primera fosforilación en determinados sustratos (de acoplamiento), que, una vez fosforilados, son reconocidos por el dominio Polo Box y esto sitúa a las proteínas Plk cerca de sus proteínas diana susceptibles de ser fosforiladas (Figura 8A).

En cuanto a la actividad de las quinasas Plk, está regulada a varios niveles. Por un lado, se ha descrito que el dominio Polo Box inhibe la actividad quinasa de las Plks por interacción intramolecular (Jang et al., 2002a). Así, mutantes de deleción en el dominio Polo Box provocan un incremento en la actividad quinasa de Plk1 (Lee and Erikson, 1997; Mundt et al., 1997; Jang et al., 2002a). Por otro lado, Plk1 se regula por fosforilación directa en el loop de activación y esta fosforilación lleva a la activación de la quinasa (Jang et al., 2002b; Nolen et al., 2004). De hecho, esta fosforilación activa a Plk1 debido a que evita su interacción con el dominio Polo Box (Jang et al., 2002a).

A

B

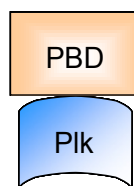

quinasas
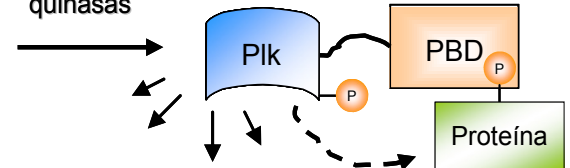

proteínas diana
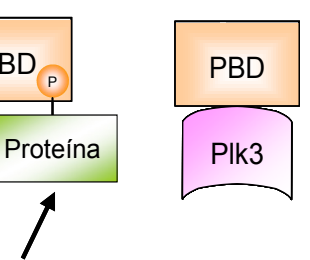

quinasas

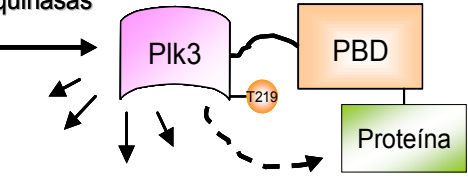

proteínas diana

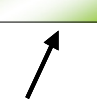

Proteína

Proteína

fosforilación inicial

Proteína

Figura 8. A) Activación de las quinasas Plk y fosforilación de sus proteínas diana. El dominio Polo Box (PBD) interacciona con proteínas diana tras una fosforilación inicial realizada por otra quinasa (Elia et al., 2003b). Esta interacción con el fosfopéptido conlleva la activación de la proteína Plk, debido a la liberación del PBD autoinhibitorio. La actividad de Plk también aumenta debido a una fosforilación en el loop de activación realizada por quinasas upstream (Jang et al., 2002b). Adaptado de Barr et al., 2004. B) La actividad de Plk3 aumenta tras su fosforilación en Thr219. La interacción del PBD tiene lugar con secuencias consenso no fosforiladas de sus proteínas de acoplamiento.

En el caso de la quinasa Plk3, el sitio predicho para la fosforilación en su loop de activación, y el consecuente incremento en su actividad quinasa, es la treonina 219. 
Por otro lado, en un principio se postuló que los dominios Polo Box de las Plks funcionaban como un módulo de unión a serina/treonina fosforiladas (Elia et al., 2003b). En el caso concreto de Plk3, estudios más recientes han demostrado que la interacción de su dominio Polo Box es mayor con secuencias no fosforiladas (van de Weerdt et al., 2008). Esto implicaría que la unión de Plk3 mediante su dominio Polo Box a proteínas (de acoplamiento) sería independiente de la fosforilación de estas (Figura 8B). Sin embargo, esta hipótesis no ha sido demostrada in vivo.

\subsubsection{La quinasa Plk3.}

a) Expresión, actividad quinasa y localización de Plk3.

La proteína quinasa Plk3, también conocida como Prk (Proliferation related kinase), se identificó como un gen de expresión temprana (Donohue et al., 1995; Li et al., 1996), ya que su ARN mensajero comienza a detectarse en la fase G1 del ciclo celular (Donohue et al., 1995; Chase et al., 1998; Anger et al., 2003).

En cuanto a la expresión a nivel de proteína, existe cierta controversia. Algunos autores describen un nivel constante de proteína a lo largo del ciclo celular (Chase et al., 1998; Bahassi el et al., 2002; Winkles and Alberts, 2005). Sin embargo, otro trabajo demuestra que el nivel de proteína se regula en el ciclo celular siendo máximo en la fase G1 (Zimmerman and Erikson, 2007b).

A nivel de tejido, se observa expresión de su ARN mensajero en todos los tejidos examinados de ratones recién nacidos. Sin embargo, en ratones adultos, se detecta una expresión moderada en tejidos como cerebro, intestino, pulmón y ovario y una alta expresión en piel (Donohue et al., 1995). En otros estudios se detectaron niveles apreciables en placenta, ovario y pulmón (Li et al., 1996) y, en cerebro adulto, además de una clara expresión de su ARN mensajero, se encontró que la actividad sináptica neuronal inducía la expresión tanto de su ARN mensajero como de la proteína (Kauselmann et al., 1999; Seeburg et al., 2005).

La actividad quinasa de Plk3 está regulada a lo largo del ciclo celular y en respuesta a diferentes tipos de estrés. De este modo, células sincronizadas mediante nocodazol en mitosis presentan un incremento de la actividad quinasa de Plk3 (Chase et al., 1998; Bahassi el et al., 2002). Otros datos indican que es más activa en fase S y G2 (Ouyang et al., 1997). Además, Plk3 se activa en respuesta a estrés oxidativo, inducido por peróxido de hidrógeno (Xie et al., 2001a; Xie et al., 2002) y adriamicina (Xie et al., 2001b). Otros estímulos que incrementan la actividad de esta quinasa son 
la luz UV (Wang et al., 2007), la radiación ionizante (Bahassi el et al., 2002) y la hipoxia (Wang et al., 2008a). De la función de la quinasa Plk3 en respuesta a daño al ADN, se hablará en mayor profundidad en el apartado siguiente.

La localización subcelular de Plk3 es muy diversa. Inicialmente, se describió en el córtex celular (adyacente a la membrana plasmática) y el surco de segmentación en citocinesis (Conn et al., 2000). Además, se encuentra en los centrosomas a lo largo del ciclo celular colocalizando con $\gamma$-tubulina (Dai et al., 2002b; Wang et al., 2002) y, en mitosis, asociada al huso mitótico y los polos de este (Wang et al., 2002; Xie et al., 2004). Por otro lado, se ha descrito en el nucleolo (Zimmerman and Erikson, 2007a, b) y en el núcleo (Wang et al., 2007). Por último, la quinasa Plk3 también se localiza en el citoplasma y asociada al aparato de Golgi, tanto en interfase como en mitosis (Dai et al., 2002b; Ruan et al., 2004; Xie et al., 2004).

En cuanto a la regulación directa del promotor de Plk3 se han descrito, hasta el momento, sitios de unión para los factores de transcripción E2F y NF-kB (Li et al., 2005; Tategu et al., 2008). El factor de transcripción NF-kB induce la expresión de Plk3 a través de una ruta activada por doxiciclina que lleva a la activación de p53 y provoca apoptosis ( $\mathrm{Li}$ et al., 2005). Por otro lado, la identificación del sitio de unión a E2F se realizó mediante el estudio de la región promotora de Plk3 utilizando un programa de análisis denominado TRANSFAC. En este caso, tanto E2F1 como E2F3 inducen la expresión del promotor de PIk3 (Tategu et al., 2008).

\section{b) Función de Plk3 en respuesta a estrés genotóxico.}

La ruta de señalización que lleva a una respuesta tras daño al ADN (estrés genotóxico) está constituida por las moléculas que detectan el daño (sensores), las moléculas que amplifican dicha señal (mediadores y transductores) y, finalmente, los efectores. Es bien conocida la función de las quinasas ATM y ATR, que actúan como sensores y amplificadores de la respuesta. Otros amplificadores son Chk1 (Checkpoint Kinase 1) y Chk2 (Checkpoint Kinase 2) y, como efectores, están el factor de transcripción p53 y las fosfatasas Cdc25, entre otros (Sancar et al., 2004). Una vez activada la ruta, se induce la expresión de diferentes genes que desencadenan una respuesta celular concreta. Dentro de las posibles respuestas, están la parada del ciclo celular, la reparación del daño al ADN y la apoptosis o senescencia. Finalmente, tiene lugar la atenuación de la respuesta (Figura 9A). Plk3 ha sido descrita como posible transductor de la señal en respuesta a distintos tipos de estrés genotóxicos (Xie et al., 2001b). 
La actividad quinasa de Plk3 se incrementa en respuesta a estrés oxidativo y daño al ADN producido por radiación ionizante o drogas miméticas de esta como adriamicina o MMS (Metil Metano Sulfonato) (Xie et al., 2001a; Xie et al., 2001b; Bahassi el et al., 2002). De hecho, esta activación es dependiente de ATM, ya que en presencia de cafeína (un inhibidor de ATM/ATR) o en líneas celulares $A^{-1}{ }^{\top}$ no se observa la activación de Plk3 (Xie et al., 2001b). Plk3 interacciona y fosforila a p53 en serina 20 (Xie et al., 2001a; Xie et al., 2001b) y, al menos en respuesta a estrés oxidativo, se ha demostrado que la fosforilación es parcialmente dependiente de Plk3. Así, en células PIk3\% o tras el uso de ARN de interferencia específico para PIk3, la fosforilación de p53 (Ser20) es menor (Xie et al., 2001a; Xie et al., 2005). De hecho, el tratamiento con wortmanina (inhibidor genérico de proteínas PIk) reduce la fosforilación en serina 20 de p53 in vivo (Liu et al., 2007). Además, la quinasa Plk3 interacciona con Chk2 y la fosforila en las serinas 62 y 73 . Esta fosforilación parece necesaria para la completa activación de Chk2 por ATM en respuesta a daño al ADN (Bahassi el et al., 2002; Bahassi el et al., 2006) (Figura 9B).

A
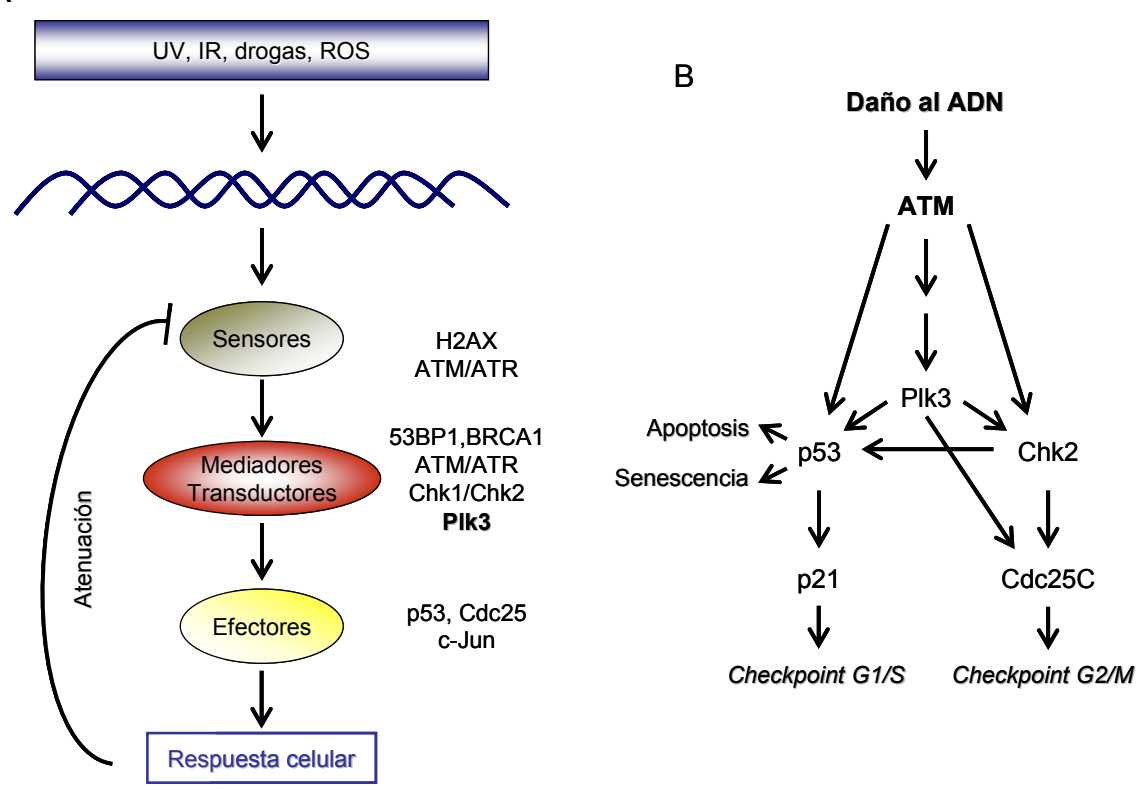

Figura 9. A) Esquema general de la respuesta celular a estrés genotóxico. La luz ultravioleta (UV), la radiación ionizante (IR), diferentes tipos de drogas y especies radicales de oxígeno (ROS) pueden provocan daño al ADN. Este es detectado por sensores que señalizan a través de proteínas transductoras ayudadas por mediadoras (53BP1, BRCA1) hasta los distintos efectores. Finalmente, se activa un mecanismo de atenuación para controlar la respuesta. Adaptado de Yang et al., 2004. B) PIk3 en relación a daño al ADN. Diferentes tipos de estrés terminan activando a Plk3, situada por debajo de ATM. Plk3 fosforila e interacciona con p53 y Chk2. Esta activación lleva a distintos tipos de respuesta a través de los efectores Cdc25C y p53. Adaptado de Bahassi el et al., 2002. 
Tanto la luz UV como la hipoxia inducen la activación de Plk3, lo que da lugar a la fosforilación del factor de transcripción c-Jun (Ser63 y Ser73), activando, en ambos casos, una respuesta de apoptosis (Wang et al., 2007; Wang et al., 2008a). Además, en respuesta a hipoxia, Plk3 también regula el factor HIF-1 $\alpha$ (Hipoxia Inducible Factor $1 \alpha$ ), provocando la desestabilización y exclusión nuclear de este (Yang et al., 2008).

Plk3 también se activa en respuesta a cisplatino (fármaco utilizado en quimioterapia) y, tras su activación, fosforila al factor de transcripción p73 provocando la inhibición de la actividad proapoptótica de este (Sang et al., 2009). Además, los niveles de ARN mensajero de Plk3 también aumentan tras tratamiento con cisplatino (Ando et al., 2004).

Aparte de estas funciones como transductor de la señal, Plk3 participa en la reparación del ADN dañado. Así, Plk3 fosforila a la subunidad p125 de la polimerasa $\delta$ (Ser60), lo que podría regular su localización subcelular ya que el residuo diana está cerca de la secuencia de localización nuclear de la polimerasa (Xie et al., 2005).

c) Implicación de PIk3 en proliferación y división celular.

La quinasa Plk3 tiene funciones clave a lo largo del ciclo celular (Figura 10). Se ha descrito que es necesaria en la transición G1/S, ya que su depleción por ARN de interferencia lleva a una parada en fase G0/G1 y a una disminución en el nivel de proteína de la ciclina $\mathrm{E}$, lo que sugiere una regulación de esta a nivel postraduccional (Zimmerman and Erikson, 2007b). Teniendo en cuenta que la fosfatasa Cdc25A regula la entrada en fase $S$ mediante la desfosforilación y activación del complejo CDK2/ciclina $\mathrm{E}$ y que Cdc25A ha sido identificada como sustrato de Plk3 in vitro, podría ser que Plk3 estuviera regulando la estabilidad de la ciclina $\mathrm{E}$ a través de la activación de Cdc25A (Myer et al., 2005; Zimmerman and Erikson, 2007b).

La entrada en mitosis depende de la fosforilación y activación de la fosfatasa Cdc25C, que desfosforila y activa el complejo Cdc2/ciclina B. Durante interfase, Cdc25C se localiza en el citoplasma y cuando entra en el núcleo, se activa y regula la transición G2/mitosis. La quinasa Plk3 participa en este proceso de acumulación de Cdc25C en el núcleo a través de su fosforilación en serina 191. De hecho, el mutante Cdc25C (S191A) no se acumula en el núcleo y, la depleción de Plk3 por ARN de interferencia, también inhibe dicha acumulación (Bahassi el et al., 2004). Sin embargo, en un estudio anterior, se identificó la serina 216 de Cdc25C como el residuo sustrato de Plk3 aunque no se llegó a determinar la función in vivo de dicha fosforilación (Ouyang et al., 1999). Plk3 también fosforila a la topoisomerasa Il $\alpha$ (Thr1342), que es 
esencial para la condensación y segregación de los cromosomas en mitosis (lida et al., 2008). Así, aunque no se ha demostrado todavía la función biológica de esta fosforilación, cabría pensar que Plk3 participe en la condensación y segregación de los cromosomas en mitosis, ya que esta función se ha descrito para otros miembros de la familia Plk (Kang et al., 2006; Godinho and Tavares, 2008). De hecho, la sobreexpresión de Plk3 provoca condensación de la cromatina (Conn et al., 2000). Otro estudio que implica a Plk3 en funciones mitóticas se realizó utilizando una RPLC (Reversed-Phase Liquid Chromatography) acoplada a un espectrómetro de masas. En este trabajo, se identificaron fosfopéptidos y complejos fosfoproteicos relacionados con el complejo CPC (Chromosomal Passenger Complex) que es un regulador de los cromosomas, el citoesqueleto y la dinámica de membranas en mitosis (Adams et al., 2001). Dentro de los motivos fosforilados detectados se encontró la serina 284 de Plk3. La fosforilación de Plk3 en este residuo lleva a esta quinasa a una localización en estructuras mitóticas como los centrosomas, los polos del huso mitótico y el surco de segmentación en citocinesis, colocalizando aquí con el CPC (Yang et al., 2007).

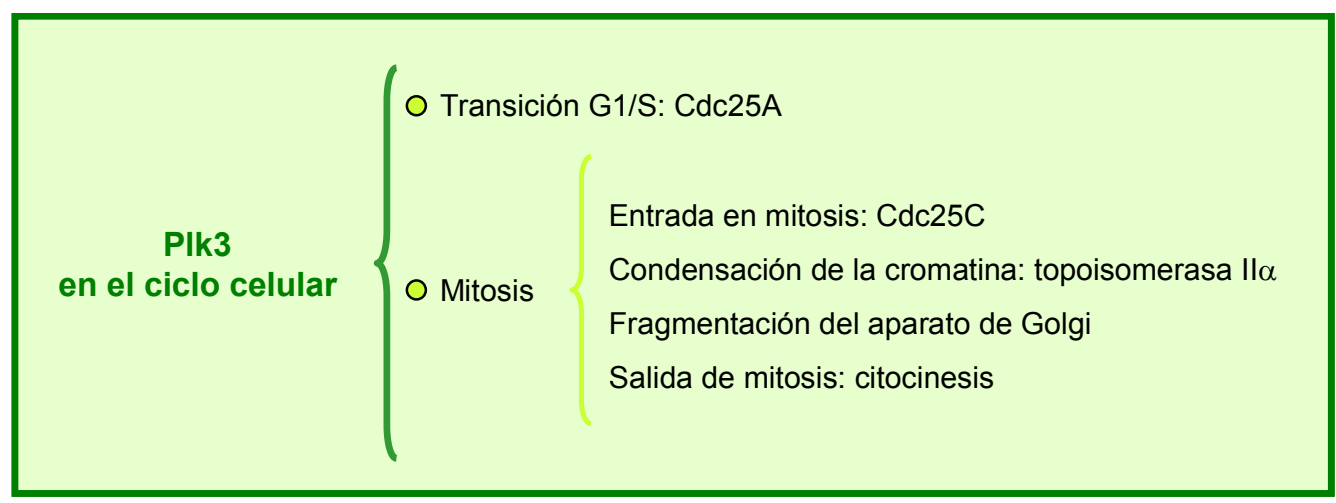

Figura 10. PIk3 en el ciclo celular. Se resumen algunos de los datos que relacionan a la quinasa Plk3 con funciones en la progresión del ciclo celular y la división celular.

Aparte de las funciones ya descritas, la localización subcelular de PIk3 en centrosomas y en el aparato de Golgi (Dai et al., 2002b) determina funciones relacionadas con estos dos orgánulos. En el primer caso, Plk3 se localiza asociada a los centrosomas a lo largo del ciclo celular (Dai et al., 2002b). De hecho, se postula un posible papel de Plk3 en la dinámica de microtúbulos y en la salida de mitosis, debido a los problemas observados en citocinesis. Así, la utilización de diferentes tipos de construcciones de Plk3 (Plk3 constitutivamente activa, Plk3 sin dominio quinasa o Plk3 inactiva) inducen cambios morfológicos en las células que pueden terminar en 
apoptosis (Wang et al., 2002; Jiang et al., 2006). Por otro lado, existe una subpoblación de Plk3 en el aparato de Golgi que colocaliza con Giantina (utilizada como marcador de dicho orgánulo) a lo largo del ciclo celular (Ruan et al., 2004). Se ha descrito que Plk3 participa en la dinámica del aparato de Golgi en mitosis debido a que su sobreexpresión induce fragmentación de este orgánulo (Ruan et al., 2004). Además, se ha llegado a determinar que en esta señalización se sitúa por debajo de la quinasa MEK1 (Xie et al., 2004). Por su parte, la sobreexpresión de MEK1 provoca un incremento en la actividad quinasa de Plk3, mientras que el tratamiento con inhibidores de MEK1, reducen dicha actividad. Esto indica que la ruta de señalización de la fragmentación del aparato de Golgi iniciada por MEK1 señaliza, en parte, a través de Plk3 (Xie et al., 2004; Feinstein and Linstedt, 2007). Como el proceso de fragmentación del aparato de Golgi en mitosis es parte de la presente tesis, se hablará en más detalle en el apartado 5 (página 41).

En cuanto a la relación de Plk3 con tumorigénesis, se ha detectado que en carcinoma de cabeza y cuello (HNSCC) (Dai et al., 2000), en cáncer de colon en ratas (Dai et al., 2002a), en carcinoma de pulmón (Li et al., 1996) y en tumores primarios de útero y vejiga (Ando et al., 2004), su expresión está reprimida. Además, se determinó que, al menos en carcinoma de pulmón, no había polimorfismos o mutaciones inactivadoras en el gen de plk3 (Wiest et al., 2001). Por otro lado, Plk3 se encuentra sobreexpresada en cáncer de ovario (Weichert et al., 2004) y cáncer de mama (Weichert et al., 2005). En estos tumores, la sobreexpresión de Plk3 está asociada, de manera significativa, con un mal pronóstico en los pacientes.

\section{La ATPasa VCP.}

\subsection{Características generales de la ATPasa VCP.}

La proteína denominada VCP (Valosin-Containing Protein) pertenece a la familia de ATPasas AAA tipo II (AAA- ATPases Associated with a variety of Activities), que se caracterizan por la gran variedad de funciones celulares que llevan a cabo.

La estructura de VCP cuenta con cuatro dominios: el dominio amino terminal (N), dos dominios ATPasa (D1 y D2) y un dominio carboxilo terminal (C) (Wang et al., 2004a) (Figura 11). 
Cada uno de los dominios de la ATPasa VCP tiene una función concreta. El dominio amino terminal $(\mathrm{N})$ interacciona con cofactores como, por ejemplo, p47 (Dreveny et al., 2004), con sustratos ubiquitinados (Dai and Li, 2001) y con lípidos (Shiozawa et al., 2006). De los dos dominios ATPasa, la actividad enzimática principal la presenta el dominio D2, mientras que el dominio D1 es responsable de la oligomerización de la proteína para formar hexámeros (Song et al., 2003; Wang et al., 2003a). El dominio carboxilo terminal (C) es la zona más flexible de la proteína y, además de interaccionar con cofactores, se han identificado algunas quinasas que fosforilan a VCP en este dominio (Livingstone et al., 2005; Vandermoere et al., 2006). De hecho, en un estudio realizado recientemente utilizando técnicas proteómicas, se detectaron un gran número de posibles dianas de fosforilación y de acetilación en VCP, muchas de ellas en el extremo carboxilo, sugiriendo una regulación muy precisa para esta ATPasa (Mori-Konya et al., 2009).

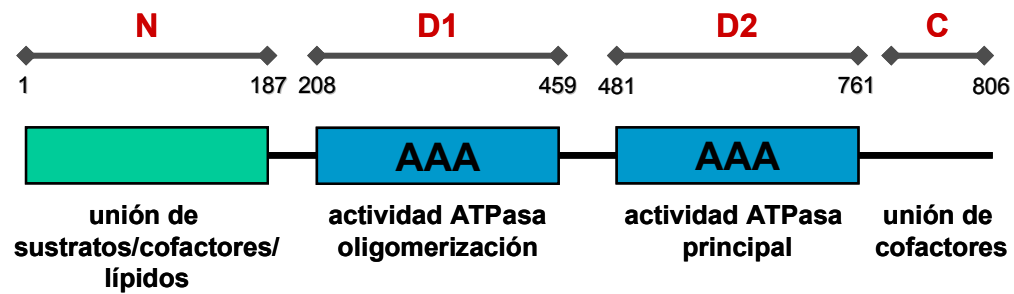

Figura 11. Resumen de la estructura y función de los dominios de la ATPasa VCP humana. La ATPasa VCP tiene 806 aminoácidos. En el esquema se indica la posición de los dominios que configuran la estructura de la proteína VCP. Los números indican la posición en aminoácidos de cada dominio.

La ATPasa VCP es una proteína abundante, constituyendo aproximadamente un $1 \%$ del contenido total de proteína en las células. Existen ortólogos de la ATPasa VCP en otros organismos como $D$. melanogaster (TER94), $X$. laevis (p97) y $S$. cerevisiae (Cdc48), con los que comparte muchas de las funciones descritas. Su localización es principalmente citoplasmática con subpoblaciones asociadas a las membranas del retículo endoplasmático y del aparato de Golgi. También se ha detectado, en menor grado, en el núcleo y en el nucleolo (Acharya et al., 1995; Latterich et al., 1995; Rabouille et al., 1995; Partridge et al., 2003).

\subsection{Funciones de la ATPasa VCP.}

La ATPasa VCP tiene diversas funciones, todas relacionadas directa o indirectamente con el sistema de ubiquitinación y degradación por el proteasoma. Entre estas funciones están, por ejemplo, la regulación del ciclo celular, la activación 
transcripcional, la fusión de membranas, la respuesta a daño al ADN y la degradación de proteínas asociada al retículo endoplasmático (ERAD- Endoplasmatic Reticulum Associated Degradation) (Wang et al., 2004a) (Figura 12). De estas funciones, se citarán algunos ejemplos.

Funciones relacionadas directamente/indirectamente con el sistema Ub-Pr
1. Proteólisis.

2. Degradación de proteínas asociada al RE (ERAD): Ufd1-Np14.

3. Ciclo celular (p. ej., ciclina E).

4. Regulación transcripcional (p. ej., NF-kB).

5. Fusión de membranas:

envuelta nuclear: Ufd1-Np14, p47 retículo endoplasmático: $\mathrm{p} 47, \mathrm{VCIP} 135$ aparato de Golgi: p47, VCIP135

6. Respuesta a daño al ADN (p. ej., ATR, ATM, DNA-PK).

Figura 12. Resumen de las funciones de la ATPasa VCP. Se muestran algunas de las funciones descritas para la ATPasa VCP. En algunos casos se reflejan los ejemplos expuestos (entre paréntesis) y los cofactores que participan (en verde). Todas estas funciones están relacionadas de un modo directo o indirecto con el sistema de ubiquitinación y degradación por el proteasoma (Ub-Pr). RE- retículo endoplasmático.

Las proteínas que son degradadas por el proteasoma son marcadas con ubiquitina (mediante poliubiquitinación debida a cadenas de ubiquitina unidas entre ellas a través de la lisina 48), lo que hace que sean específicamente reconocidas por toda la maquinaria de degradación. Pero hay que tener en cuenta que la ubiquitinación también regula procesos independientes del proteasoma. En estos casos, los sustratos se modifican con una única molécula de ubiquitina (monoubiquitinación) o con cadenas de ubiquitina que se unen entre ellas a través de la lisina 63 o la lisina 6 (Schnell and Hicke, 2003; Ikeda and Dikic, 2008). La relación de la ATPasa VCP con la proteólisis es directa ya que interacciona con proteínas poliubiquitinadas y con distintos componentes del sistema de degradación como la subunidad $26 \mathrm{~S}$ del proteasoma (Dai et al., 1998; Dai and Li, 2001). La conexión del resto de las funciones de la ATPasa con el sistema ubiquitina-proteasoma en muchos casos es más difusa. De hecho, en la actualidad se piensa que algunas de sus funciones están relacionadas exclusivamente con el sistema de ubiquitinación (monoubiquitinación) sin la posterior degradación (Ye, 2006).

El sistema de degradación asociado al retículo endoplasmático (ERAD) se caracteriza porque las proteínas mal plegadas son llevadas a la cara citosólica del retículo endoplasmático para marcarlas con ubiquitina (poliubiquitinación) y enviarlas a degradación. La ATPasa VCP participa en este proceso asociada a los cofactores 
Ufd1-Np14. El complejo VCP-Ufd1-Np14 se une a la proteína poliubiquitinada y la hidrólisis del ATP empuja dicha proteína al citoplasma para que finalmente sea degradada por el proteasoma (Ye et al., 2003).

La implicación de VCP con el ciclo celular tiene una relación directa con el sistema ubiquitina-proteasoma, ya que muchas de las proteínas que participan en la progresión del ciclo celular ( $p$. ej., ciclinas) son degradadas cuando ya no son necesarias. Así, la ATPasa VCP ha sido implicada directamente con la degradación de la ciclina $\mathrm{E}$ in vivo e in vitro (Dai and Li, 2001).

Otra de las funciones asociadas a VCP es la activación de factores de transcripción, que está directamente relacionada con el sistema ubiquitinaproteasoma. Uno de los factores regulados por VCP es el factor NF-kB, que se encuentra inactivo en el citoplasma debido a su interacción con la proteína inhibidora $\mid \kappa-B \alpha$. Cuando las células reciben el estímulo adecuado, el factor $I_{\kappa}-B \alpha$, además de fosforilarse, se poliubiquitina. VCP reconoce la proteína $I_{\kappa}-\mathrm{B} \alpha$ ubiquitinada y la disocia del factor NF-кB que es capaz de ir al núcleo y regular sus genes diana. Por su parte, el inhibidor $\mid \kappa-B \alpha$ es degradado por el proteasoma (Dai et al., 1998).

La función exacta de VCP en respuesta a daño al ADN no es conocida. Lo que se ha descrito hasta ahora es su fosforilación en serina 784 tras daño al ADN por las quinasas ATM, ATR y DNA-PK. De hecho, tras el daño al ADN, se observa cómo la proteína VCP del núcleo se localiza en las zonas de rotura de la cadena de ADN, lo que sugiere su participación en reparación (Livingstone et al., 2005). Además, también se ha descrito que proteínas relacionadas con la reparación del ADN como BRCA1 y la helicasa WRN interaccionan con VCP (Zhang et al., 2000; Partridge et al., 2003). Cabe añadir que cuando se desencadena la respuesta de daño al ADN tienen lugar modificaciones postraduccionales por fosforilación y por ubiquitinación (monoubiquitinación o poliubiquitinación a través de Lys63), lo que implicaría directamente a VCP en este proceso (Hofmann, 2009).

\subsubsection{Implicación de VCP en la fusión de membranas.}

La división celular implica un drástico remodelamiento de las membranas ya que las células tienen que dividir su material genético y repartir sus orgánulos entre las dos células hijas. La envuelta nuclear, el retículo endoplasmático y el aparato de Golgi existen como una única copia y, para repartirse, se fragmentan al inicio de mitosis. En telofase, los orgánulos se reensamblan de nuevo. La ATPasa VCP participa en la fusión de las membranas de estos tres orgánulos en telofase y, en el caso del aparato 
de Golgi, también se ha demostrado su implicación en la fragmentación de este al inicio de la mitosis. De la señalización en la dinámica del aparato de Golgi en división celular se hablará en mayor detalle en el apartado siguiente.

La participación de VCP en el reensamblaje de la envuelta nuclear tiene lugar a dos niveles: en la formación de la envuelta nuclear continua asociada a la cromatina y en la expansión de esta (Hetzer et al., 2001). Para cada fase requiere cofactores distintos y excluyentes (Meyer et al., 2000; Bruderer et al., 2004). Así, para el primer paso se asocia con el dímero Ufd1-Np14 y para el posterior crecimiento se asocia con el cofactor p47. El mecanismo exacto de cómo lleva a cabo estas funciones no se conoce (Hetzer et al., 2001).

La fusión de membranas (p. ej., en el caso de las vesículas de transporte con su membrana de destino) es un proceso muy específico donde la correcta fusión entre dos membranas viene determinada, entre otras cosas, por la interacción específica de marcadores en ambas membranas denominados SNAREs (Soluble NSF Attachment protein Receptor). En el caso de una fusión entre una vesícula y su membrana diana, se establece una interacción tipo v/t-SNARE (vesicle/target-SNARE), mientras que cuando la fusión ocurre entre dos membranas la interacción es de tipo t/t-SNARE (target/target-SNARE) (Rothman and Warren, 1994) (Figura 13).

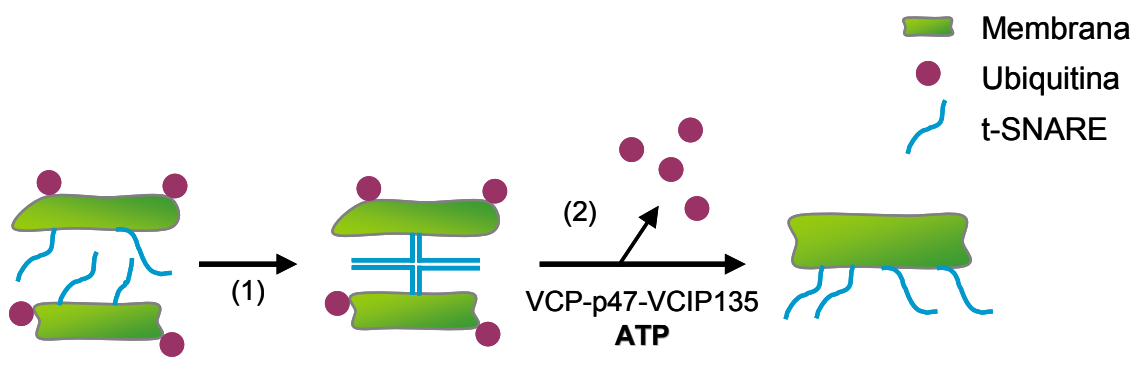

Figura 13. Fusión de membranas del AG y del RE mediada por VCP. El mecanismo de fusión que tiene lugar en las membranas del AG y del RE mediado por VCP es similar. Las proteínas tSNARE de cada membrana interaccionan formando un complejo que se estabiliza por interacciones hidrofóbicas (1). A este complejo se unen VCP-p47-VCIP135. La hidrólisis del ATP provoca la fusión y que VCIP135 desestabilice el complejo formado (2). El AG sufre además un ciclo de ubiquitinación/deubiquitinación en mitosis. AG- aparato de Golgi. RE- retículo endoplasmático.

La formación de complejos SNARE y su posterior liberación da lugar a la fusión de las membranas y permite la reutilización de los SNAREs en nuevos ciclos de fusión. Este proceso requiere de energía en forma de ATP y, por tanto, de la participación de enzimas ATPasas (Sollner et al., 1993). 
La fusión de las membranas del retículo endoplasmático y del aparato de Golgi llevada a cabo por VCP sigue un mecanismo similar, haciendo uso de los mismos cofactores: p47 y VCIP135 (VCP [p97]/p47 Complex Interacting Protein, p135) (Uchiyama et al., 2002; Kano et al., 2005). En ambos procesos la modificación de sustratos por monoubiquitinación parece jugar un papel fundamental. De hecho, tanto p47 como VCIP135 están directamente relacionados con la ubiquitinación. El cofactor p47 tiene un dominio UBA de unión a ubiquitina (UBA- Ubiquitin-Associated domain) y el cofactor VCIP135 es una enzima deubiquitinasa, de modo que la presencia de sustratos monoubiquitinados parece clave en el mecanismo de actuación del complejo VCP-p47-VCIP135 en la fusión de membranas (Meyer et al., 2002; Wang et al., 2004b). De hecho, al menos en el caso del aparato de Golgi, la ubiquitinación durante el proceso de fragmentación al inicio de mitosis es necesaria para que tenga lugar la fusión de membranas en telofase. Así, se piensa que determinadas proteínas en las membranas de aparato de Golgi, hasta el momento desconocidas, se ubiquitinan durante la fragmentación y son deubiquitinadas durante la fusión de las membranas donde tendría un papel clave la enzima deubiquitinasa VCIP135 (Wang et al., 2004b). La proteína t-SNARE que participa en la fusión de membranas mediada por el complejo VCP-p47-VCIP135 es la proteína Syntaxin-5, en el caso del aparato de Golgi, y la proteína Syntaxin-18, en el caso del retículo endoplasmático (Rabouille et al., 1998; Kano et al., 2005). Para que tenga lugar la fusión de membranas, primero se deben formar complejos t/t-SNARE mediante interacciones hidrofóbicas (Figura 13, en azul), a los que, a continuación, se uniría el complejo VCP-p47-VCIP135. En el caso del aparato de Golgi, se ha demostrado que tanto p47 como VCIP135 interaccionan con la proteína t-SNARE Syntaxin-5 (Rabouille et al., 1998; Uchiyama et al., 2002). Así, se establece un complejo transitorio que VCIP135 disocia tras la hidrólisis del ATP por la ATPasa VCP, permaneciendo la interacción VCP-VCIP135 (Uchiyama et al., 2002).

Para el aparato de Golgi también ha sido demostrada la implicación del complejo VCP-p47 en la fragmentación de dicho orgánulo al inicio de mitosis (Uchiyama et al., 2003). De este proceso se hablará específicamente en el apartado siguiente. 


\section{Dinámica del aparato de Golgi en división celular.}

\subsection{Organización y función del aparato de Golgi.}

El aparato de Golgi en mamíferos está compuesto por una serie de cisternas apiladas y conectadas lateralmente entre sí formando un sistema continuo de membranas que se localiza en la región perinuclear cerca del centrosoma (Figura 14A) (Ladinsky et al., 1999). Su organización, función y localización requiere de la participación de proteínas estructurales del aparato de Golgi denominadas golgins (p.ej., GM130) y GRASPs (GRASP- Golgi ReAssembly Protein) y del citoesqueleto de microtúbulos y de actina (Figura 14B) (Valderrama et al., 1998; Thyberg and Moskalewski, 1999; Ramirez and Lowe, 2009). Además, su estructura y su orientación son clave para la direccionalidad del transporte y para la polaridad celular y, por tanto, para procesos relacionados como la migración celular (Bisel et al., 2008; Yadav et al., 2009).

El aparato de Golgi lleva a cabo funciones esenciales para el crecimiento, homeostasis y división celular. Dentro de estas funciones están la modificación de lípidos y proteínas (Farquhar and Palade, 1998), el transporte de proteínas desde el retículo endoplasmático hasta la membrana plasmática u otras localizaciones intracelulares (Rothman, 1994) y su función de scaffold para la señalización celular (Donaldson and Lippincott-Schwartz, 2000; Torii et al., 2004; Feinstein and Linstedt, 2007; Feng et al., 2007).

A

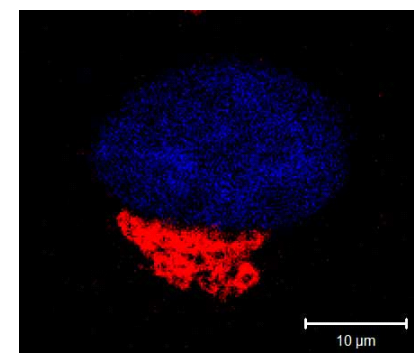

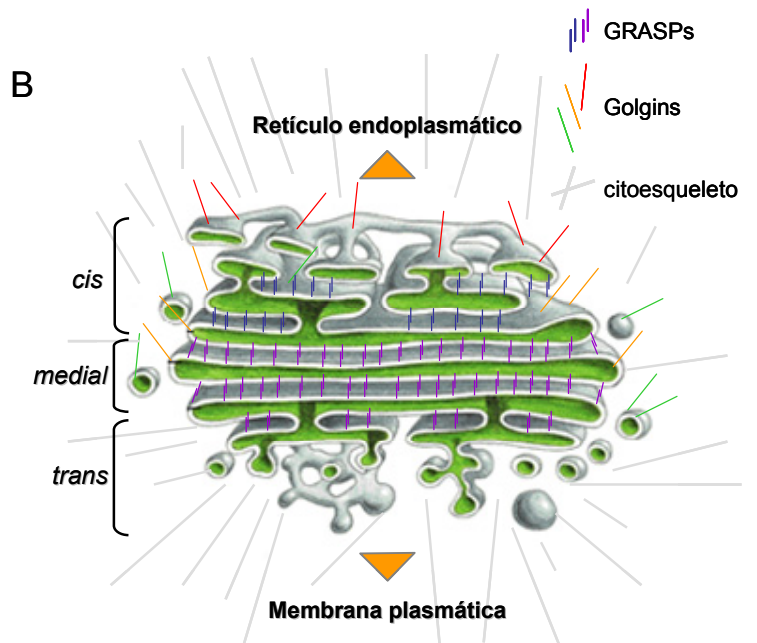

Figura 14. Localización y estructura del aparato de Golgi. A) Inmunofluorescencia de una célula A549 que muestra la localización del aparato de Golgi marcado con Giantina (en rojo) respecto del núcleo marcado con DAPI (en azul). La barra indica $10 \mu \mathrm{m}$. B) Esquema de los distintos componentes que mantienen la estructura y organización del aparato de Golgi en interfase. Entre estos elementos se encuentran las golgins (p.ej., GM130), las GRASPs (GRASP55 y GRASP65) y el citoesqueleto de microtúbulos y de actina. 
Durante la división celular, el aparato de Golgi sufre un ciclo de fragmentación/reensamblaje necesario para su reparto entre las dos células hijas que es estrictamente regulado y coordinado con la progresión de la mitosis.

\subsection{Fragmentación del aparato de Golgi en la transición G2/ mitosis.}

El aparato de Golgi es un sistema continuo de membranas que se reparte entre las dos células hijas en mitosis. Para ello, lo primero es la rotura de las uniones laterales entre las cisternas para, a continuación, fragmentarse en múltiples vesículas y túbulos. Al mismo tiempo que los cromosomas se segregan, las membranas mitóticas del aparato de Golgi, se reparten entre las dos células hijas. En telofase, las membranas se fusionan y se reensambla de nuevo el aparato de Golgi (Shorter and Warren, 2002). Además, se ha descrito que su fragmentación no es solamente necesaria para su reparto, sino también para la entrada en mitosis (Sutterlin et al., 2002; Hidalgo Carcedo et al., 2004).

\subsubsection{Mecanismo y rutas de señalización.}

Se han encontrado diversas proteínas relacionadas con el desensamblaje y reensamblaje del aparato de Golgi en mitosis. Muchas de ellas son quinasas, ya que es un proceso en el que la regulación por fosforilación es clave. Las quinasas hasta el momento descritas en este proceso son Cdc2, Raf-1, MEK1, ERK1c, ERK2, Plk1 y Plk3 (Acharya et al., 1998; Kano et al., 2000; Sutterlin et al., 2001; Colanzi et al., 2003b; Xie et al., 2004; Shaul and Seger, 2006). También participan proteínas de la matriz del aparato de Golgi como GM130, GRASP65 y GRASP55 (Lowe et al., 1998; Lin et al., 2000; Jesch et al., 2001a), complejos proteicos relacionados con la fusión de membranas como VCP (Uchiyama et al., 2003) y la proteína de fisión CtBP3/BARS (BARS) (Hidalgo Carcedo et al., 2004).

El proceso de fragmentación ocurre en dos fases: la rotura lateral de las uniones entre cisternas (fase I) y el desensamblaje de estas hasta su total dispersión por el citoplasma (denominado Golgi mitotic haze) (fase II) (Shorter and Warren, 2002; Colanzi et al., 2003a; Axelsson and Warren, 2004; Persico et al., 2009) (Figura 15).

a) Rotura de las uniones laterales de las cisternas (fase I).

Hay varias proteínas clave en la rotura de las uniones laterales entre las cisternas (también denominadas zonas no compactas del aparato de Golgi): la quinasa MEK1, 
la proteína de fisión CtBP3/BARS, GRASP55 y GRASP65. Este proceso ocurre al final de la fase G2 del ciclo celular y lleva al aislamiento de las cisternas (Figura 15, fase I).

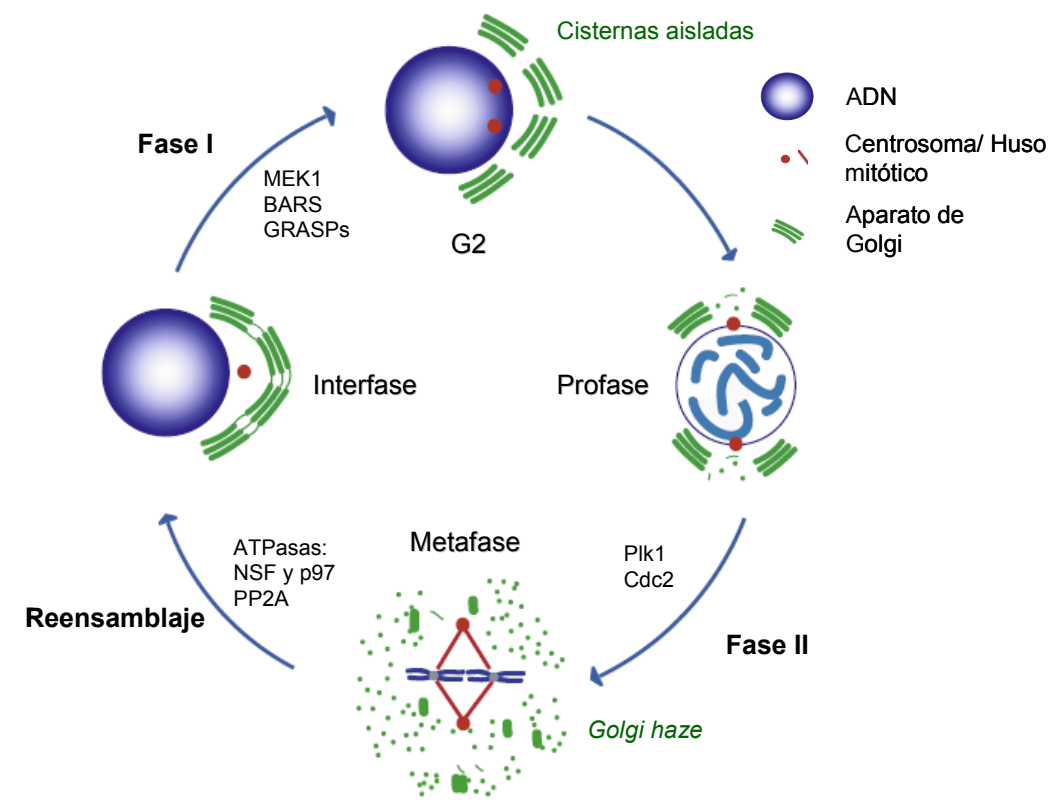

Figura 15. Representación esquemática del proceso de desensamblaje/reensamblaje del aparato de Golgi en mitosis. En interfase, el aparato de Golgi forma un sistema continuo de membranas localizado en la región perinuclear cerca del centrosoma (en rojo). Al final de la fase $\mathrm{G} 2$, se rompen las uniones laterales dando lugar a cisternas aisladas (fase I) y, ya en mitosis, se fragmenta completamente (fase II). En telofase, las membranas del aparato de Golgi vuelven a reensamblarse de nuevo. Adaptado de Persico et al., 2009.

Las funciones de la ruta de las MAP quinasas son regular la proliferación, la diferenciación y la apoptosis (Chang and Karin, 2001). Sin embargo, se ha descrito que no solamente se activan por señales mitogénicas para sus funciones en el ciclo celular sino también específicamente en mitosis para regular diversos procesos, entre ellos, la fragmentación del aparato de Golgi (Shapiro et al., 1998; Laird et al., 1999). La participación de la quinasa MEK1 fue descrita por primera vez utilizando un sistema de células NRK de riñón de rata permeabilizadas (NRK-Normal Rat Kidney), que, al incubarse con extractos mitóticos, sufrían fragmentación del aparato de Golgi (Acharya et al., 1998). Se determinó que MEK1 era responsable de la rotura de las uniones laterales de las cisternas y que su papel era minoritario en el posterior desensamblaje (Acharya et al., 1998; Colanzi et al., 2000; Kano et al., 2000; Feinstein and Linstedt, 2007). La quinasa MEK1 se activa específicamente en mitosis y su quinasa upstream Raf-1 es necesaria aunque no suficiente para dicha activación y, por tanto, Raf-1 también participa en la fragmentación del aparato de Golgi en mitosis (Shapiro et al., 
1998; Colanzi et al., 2000; Colanzi et al., 2003b). Además, se ha demostrado que la depleción de MEK1 por ARN de interferencia o la sobreexpresión de un mutante dominante negativo de MEK1 provocan retraso en la transición G2/mitosis del ciclo celular (Wright et al., 1999; Feinstein and Linstedt, 2007). Las proteínas descritas por debajo de MEK1 son ERK1c, ERK2 y Plk3. Así, existe una subpoblación de ERK1c localizada en el aparato de Golgi cuya actividad quinasa aumenta en mitosis y tras la sobreexpresión de MEK1 (Aebersold et al., 2004; Shaul and Seger, 2006). Por otro lado, un trabajo más reciente especifica que la activación de ERK1c es mediada por la isoforma MEK1b (Shaul et al., 2009). En cuanto a ERK2, se ha determinado que fosforila a GRASP55 (Thr222, Thr225, Ser245 y Thr249) downstream de MEK1 en mitosis (Jesch et al., 2001a; Feinstein and Linstedt, 2007). Plk3, por su parte, también se localiza en el aparato de Golgi y su sobreexpresión en células HeLa no sincronizadas induce la fragmentación de este (Ruan et al., 2004). Plk3 se sitúa por debajo MEK1 en este proceso, ya que células previamente tratadas con un inhibidor específico de MEK1, no fragmentan el aparato de Golgi tras la sobreexpresión de Plk3. Además, la sobreexpresión de MEK1 induce la activación de la actividad quinasa de Plk3. Por lo tanto, Plk3 participaría en la primera fase de la fragmentación por debajo de MEK1, aunque su función exacta está por determinar (Xie et al., 2004) (Figura $16 A)$.

GRASP55 y GRASP65 son proteínas periféricas de membrana de la matriz del aparato de Golgi implicadas tanto en el mantenimiento de las conexiones laterales entre las cisternas como entre las propias cisternas (Barr et al., 1997; Shorter et al., 1999; Puthenveedu et al., 2006; Feinstein and Linstedt, 2008; Tang et al., 2010). Tanto GRASP55 como GRASP65 forman homodímeros y se ha propuesto que dímeros localizados en cisternas adyacentes pueden oligomerizar en trans y configurar la estructura del aparato de Golgi. La oligomerización en trans es interrumpida en mitosis por la fosforilación en su dominio Ser/Pro (SPR), localizado en su extremo carboxilo, lo que llevaría a la rotura de las uniones laterales de las cisternas (Wang et al., 2003b; Wang et al., 2005; Wang et al., 2008b; Xiang and Wang, 2010). Ambas proteínas son fosforiladas en mitosis por diversas quinasas. Así, GRASP65 es fosforilada por Cdc2 y Plk1 (Lin et al., 2000; Wang et al., 2003b; Wang et al., 2005; Yoshimura et al., 2005) y GRASP55 por ERK2 (Jesch et al., 2001a; Feinstein and Linstedt, 2007). Considerando la diferente localización de GRASP55 y GRASP65 (medial/trans-Golgi y cis-Golgi, respectivamente), se piensa que estas proteínas son responsables del mantenimiento de las conexiones entre las cisternas y de la consecuente rotura en mitosis en esas 
regiones del aparato de Golgi (Shorter et al., 1999; Duran et al., 2008; Feinstein and Linstedt, 2008; Xiang and Wang, 2010).

La proteína de fisión BARS tiene dos funciones principales. Por un lado, actúa como correpresor transcripcional en el núcleo y, por otro, está implicada en procesos de fisión de membranas en el aparato de Golgi (Yang et al., 2005; Corda et al., 2006). Se ha demostrado que es una proteína clave en la fragmentación del aparato de Golgi porque su depleción por ARN de interferencia o el uso de anticuerpos bloqueadores específicos evitan la rotura lateral de las cisternas en células permeabilizadas NRK tratadas con extracto mitótico (Hidalgo Carcedo et al., 2004; Colanzi et al., 2007). Además, BARS es fosforilada en mitosis (Boyd et al., 1993).

A

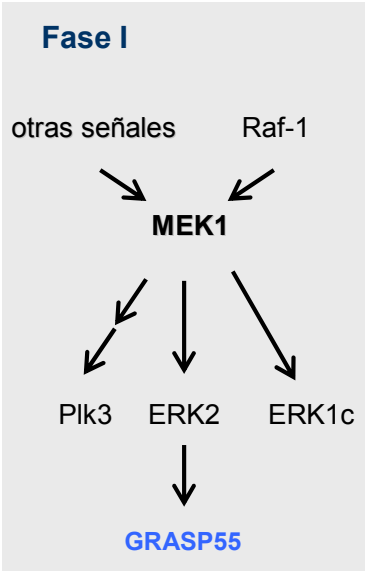

B

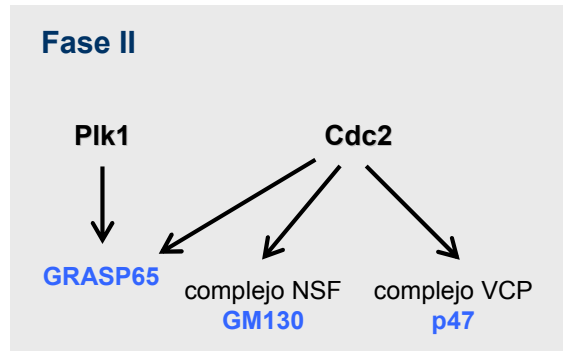

Figura 16. Resumen de las quinasas y sus sustratos implicados en la fragmentación del aparato de Golgi en mitosis. A) La quinasa mejor establecida por su función en la fase I de la fragmentación del AG es MEK1. Se muestra su quinasa upstream y sus quinasas downstream con los sustratos conocidos (en azul). B) Plk1 y Cdc2 son las quinasas implicadas en la fase II de la fragmentación del AG. Se muestran sus sustratos conocidos (en azul). AG- aparato de Golgi.

\section{b) Desensamblaje de las cisternas (fase II).}

En profase, el aparato de Golgi sufre una fragmentación continua hasta metafase dando lugar a gran número de vesículas y túbulos que se localizan alrededor de los polos del huso mitótico (Figura 15, fase II). Estudios in vivo muestran que, además de fragmentarse, se producen varios movimientos de dispersión (Shima et al., 1998). Así, los fragmentos del aparato de Golgi perinucleares sufren un movimiento centrípeto al mismo tiempo que tiene lugar la rotura de la envuelta nuclear. A continuación, estos fragmentos se distribuyen en dos poblaciones alrededor de los polos del huso mitótico (Shima et al., 1998; Wei and Seemann, 2009b). 
En este proceso participan quinasas como Plk1 y Cdc2, proteínas de la matriz del aparato de Golgi como GM130, complejos proteicos de ATPasas como VCP y GTPasas como ARF-1 (Figura 16B).

La quinasa Plk1 participa en diversos procesos de la división celular como la entrada en mitosis, la formación del huso mitótico y la citocinesis (Barr et al., 2004). De modo que tratando de identificar nuevas proteínas relacionadas con Plk1, se realizó un screening utilizando un ensayo de doble híbrido y así se identificó la proteína GRASP65 (Lin et al., 2000). GRASP65 interacciona y es sustrato de Plk1 in vitro e in vivo (Lin et al., 2000; Sutterlin et al., 2001; Wang et al., 2003b). Además, se demostró mediante ensayos in vivo la implicación directa de la quinasa en el proceso de fragmentación. Así, la sobreexpresión de un mutante de Plk1 inactivo o su depleción por ARN de interferencia inhiben la fragmentación del aparato de Golgi en un sistema de células NRK incubadas con extracto mitótico. Sin embargo, en este mismo sistema, Plk1 por sí sola, no es capaz de inducir el desensamblaje de las cisternas (Sutterlin et al., 2001). Sin embargo, utilizando un sistema de cisternas de aparato de Golgi de rata, se demostró que Plk1 es capaz de inducir, por sí sola, el desensamblaje de estas (Wang et al., 2003b).

La quinasa Cdc2 es clave para diversos procesos mitóticos como la condensación de los cromosomas, la formación del huso mitótico y el desensamblaje de la envuelta nuclear (Nigg, 1995). Aparte de haberse descrito que fosforila a GRASP65 (Lin et al., 2000; Wang et al., 2003b; Wang et al., 2005), participa en el bloqueo de los procesos de fusión de membranas, lo que es necesario para que el desensamblaje de las cisternas del aparato de Golgi en vesículas y túbulos ocurra en mitosis. El proceso de fusión de membranas requiere de energía en forma de ATP y, por lo tanto, la participación de ATPasas. Se han descrito dos rutas de ATPasas en la fusión de membranas: NSF ( $N$-ethylameimide-Sensitive Factor) y VCP (Rabouille et al., 1995). La quinasa Cdc2 está relacionada con ambas rutas ya que fosforila a proteínas esenciales como GM130 y p47 (Lowe et al., 1998; Uchiyama et al., 2003).

El transporte de vesículas se lleva a cabo utilizando distintos tipos de proteínas de revestimiento que facilitan la deformación de las membranas. Dentro de estas están las vesículas revestidas tipo COPI y tipo COP II (COP- Coat Protein). Las vesículas revestidas COPI están implicadas en el transporte a través del aparato de Golgi y el transporte retrógrado al retículo endoplasmático. Por su parte, las vesículas revestidas COPII participan en el transporte desde el retículo endoplasmático al aparato de Golgi (Figura 17A). Una vez formadas las vesículas, pierden su envoltura y se fusionan con 
sus membranas diana mediante un proceso de anclaje y la posterior formación de los complejos SNARE específicos (Rothman and Warren, 1994). A continuación, la hidrólisis del ATP por la ATPasa NSF provocaría la fusión (Sollner et al., 1993). Se ha descrito que la ATPasa NSF interacciona con complejos SNARE formados por la proteína v-SNARE denominada GOS-28 y la proteína t-SNARE denominada Syntaxin5 (Rabouille et al., 1998). Previo a la formación del complejo SNARE, se produce un proceso de anclaje de la vesícula con su membrana diana. En este punto del proceso, participan las golgins denominadas p115 y GM130. La proteína GM130 está anclada a las membranas del aparato de Golgi por su extremo carboxilo e interacciona por su extremo amino con la proteína p115 (Nakamura et al., 1995; Nakamura et al., 1997). La proteína p115 funciona como anclaje inicial entre las vesículas revestidas COPI (a través de la Giantina) y las cisternas (a través de GM130), formando un complejo p115-GM130-Giantina (Sonnichsen et al., 1998). En mitosis, Cdc2 fosforila a la proteína GM130 (Ser25), lo que impide su interacción con p115 y, por tanto, evita la formación del anclaje inicial, lo que lleva a que las vesículas no se fusionen y da lugar a una continua formación de vesículas sin su posterior fusión. Este fenómeno consume aproximadamente un $60 \%$ de las membranas del aparato de Golgi in vitro y explicaría cómo tiene lugar el proceso en mitosis (Misteli and Warren, 1994; Lowe et al., 1998; Lowe et al., 2000; Seemann et al., 2000b).

A

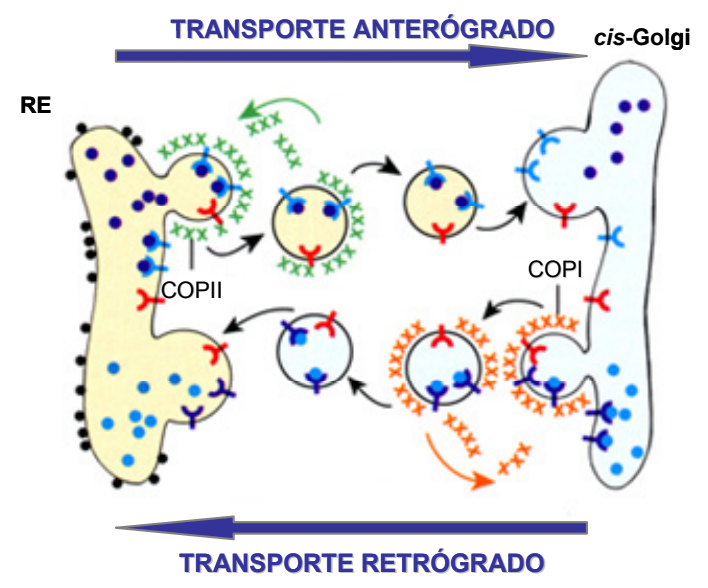

B

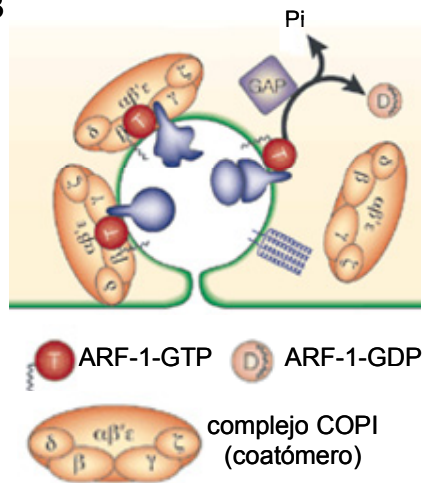

Figura 17. A) Transporte de vesículas mediado por COPI y COPII. Las vesículas COPI están implicadas en el transporte a través del AG y el transporte retrógrado al RE, mientras que las vesículas COPIl participan en el transporte del RE al AG. RE- retículo endoplasmático. AGaparato de Golgi. B) Implicación de la GTPasa ARF-1 en la formación de vesículas tipo COPI. La forma activa de ARF-1 (ARF-1-GTP) recluta subunidades proteicas para formar los complejos COPI y las vesículas de este tipo. Adaptado de Kirchhausen, 2000. 
La ATPasa VCP hace uso de distintos cofactores para llevar a cabo sus funciones. En el caso de la fusión de membranas del aparato de Golgi, VCP funciona asociada a tres cofactores, p47, p37 y VCIP135, formando dos tipos de complejos: VCP-p47-VCIP135 y VCP-p37-VCIP135. Sin embargo, solamente se ha descrito la regulación de p47 en relación con la fragmentación del aparato de Golgi en mitosis (Kondo et al., 1997; Uchiyama et al., 2002; Uchiyama et al., 2003; Uchiyama et al., 2006). El cofactor p47 interacciona con la proteína t-SNARE denominada Syntaxin-5, lo que la sitúa en las membranas del aparato de Golgi y, probablemente, sea responsable de la localización allí de la ATPasa VCP (Rabouille et al., 1998). En mitosis, la quinasa Cdc2 fosforila a p47 (Ser140) y esta fosforilación tiene como consecuencia la deslocalización del complejo proteico VCP-p47 lo que impide los procesos de fusión (Uchiyama et al., 2003).

Otro elemento importante es la GTPasa ARF-1 (ADP-Ribosylation Factor-1). La forma activa de ARF-1 (GTP-ARF-1) se ancla a las membranas del cis/medial-Golgi y se encarga de reclutar las subunidades proteicas que forman el complejo COPI (coatómero) para formar las vesículas de este tipo (Figura 17B). Su función en la fragmentación del aparato de Golgi es controvertida ya que algunos estudios sugieren que es necesaria su inactivación en mitosis (Altan-Bonnet et al., 2003; Altan-Bonnet et al., 2006), mientras que otros aseguran que es clave que permanezca activa para una continua formación de vesículas COPI y la consecuente fragmentación de las membranas en mitosis (Xiang et al., 2007; Tang et al., 2008). En un sistema in vitro que simula el proceso de desensamblaje/reensamblaje de las cisternas del aparato de Golgi, se determinó que ARF-1 y el complejo COPI eran clave para la formación de vesículas. Sin embargo, para reproducir un desensamblaje completo eran también necesarias las quinasas Cdc2 y Plk1 (Tang et al., 2008). De este modo, parece que las quinasas se encargan del desensamblaje de las cisternas y que la GTPasa ARF-1 y el complejo COPI se encargan de la fragmentación en vesículas (Misteli and Warren, 1994; Tang et al., 2008).

En metafase, el aparato de Golgi está completamente fragmentado y disperso por la célula (Figura 18) (Shima et al., 1998). Se han propuesto dos modelos para tratar de explicar el mecanismo que lleva al reparto de los fragmentos del aparato de Golgi entre las dos células hijas. Uno de ellos propone que el aparato de Golgi está en equilibrio dinámico con el retículo endoplasmático y asume que las membranas del aparato de Golgi son absorbidas y segregadas con el retículo endoplasmático de un 
modo similar a la envuelta nuclear durante la mitosis (Zaal et al., 1999; Altan-Bonnet et al., 2006). Por otro lado, se encuentra el modelo que considera que el aparato de Golgi se fragmenta en vesículas y túbulos que se reparten independientemente del retículo endoplasmático (Pelletier et al., 2000; Jesch et al., 2001b; Shorter and Warren, 2002; Axelsson and Warren, 2004; Barr, 2004). Esto implica que los túbulos y vesículas generados de la fragmentación del aparato de Golgi permanecen independientes de las membranas del retículo endoplasmático durante la mitosis (Jesch et al., 2001b; Jokitalo et al., 2001; Axelsson and Warren, 2004; Pecot and Malhotra, 2004). Además, en relación con este último modelo, se piensa que es el huso mitótico el que regula el reparto del aparato de Golgi en mitosis (Shima et al., 1998; Jokitalo et al., 2001; Wei and Seemann, 2009b).

c) Implicación del huso mitótico.

La acumulación de los fragmentos y vesículas del aparato de Golgi alrededor de los polos del huso mitótico (Shima et al., 1998; Seemann et al., 2002; Axelsson and Warren, 2004; Wei and Seemann, 2009b) y la exclusión del retículo endoplasmático de esta región (Jesch et al., 2001b; Axelsson and Warren, 2004) apoyan el modelo de reparto independiente del aparato de Golgi. Además, la hipótesis de que el huso mitótico juega un papel fundamental en el reparto del aparato de Golgi en mitosis se sustenta, por un lado, en que el reparto es preciso en un modo comparable a la segregación de los cromosomas, que utiliza el huso mitótico para este fin, y, por otro, en la localización de los fragmentos y vesículas del aparato de Golgi alrededor de los polos del huso mitótico en metafase (Shima et al., 1998; Seemann et al., 2002; Bartz et al., 2008; Wei and Seemann, 2009d). De este modo, los fragmentos mitóticos del aparato de Golgi se distribuyen asociados al huso mitótico a lo largo de la mitosis (Shima et al., 1998; Seemann et al., 2002; Wei and Seemann, 2009b).

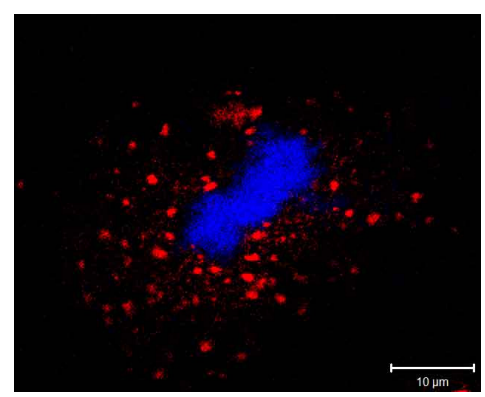

Figura 18. Inmunofluorescencia de una célula A549 en metafase. El aparato de Golgi se detecta con un anticuerpo para Giantina (rojo) y el ADN se detecta con DAPI (azul). Se observan los fragmentos mitóticos del aparato de Golgi alrededor de la placa metafásica. La barra indica $10 \mu \mathrm{m}$. 
A pesar de que existían indicios del papel del huso mitótico en el reparto de los fragmentos del aparato de Golgi en mitosis, el trabajo clave que los relaciona directamente se ha llevado a cabo recientemente por Wei y Seemann que desarrollaron un método capaz de inducir una división celular asimétrica, consiguiendo que sólo una de las células hijas adquiera el huso mitótico, aunque ambas reciben fragmentos del aparato de Golgi (Wei and Seemann, 2009a). Los aparatos de Golgi de ambas células tienen función secretora. Sin embargo, en ausencia del huso mitótico las cisternas del aparato de Golgi permanecen dispersas por el citoplasma y no se llegan a conectar lateralmente (Wei and Seemann, 2009b). Esto implica que existen dos tipos de reparto y que, al menos, los elementos necesarios para un correcto reensamblaje del aparato de Golgi se reparten entre las dos células hijas asociados al huso mitótico (Wei and Seemann, 2009b). Además, hay que tener en cuenta que, a pesar de que ambas células hijas mantienen la función secretora intacta, otras funciones asociadas con la correcta estructura y orientación del aparato de Golgi podrían estar afectadas. Así, aunque Wei y Seemann no lo hayan medido en el trabajo realizado mediante la técnica de la división asimétrica (Wei and Seemann, 2009b), otros investigadores han demostrado la importancia de la estructura y localización del aparato de Golgi en mamíferos para funciones como, por ejemplo, la migración celular (Bisel et al., 2008; Yadav et al., 2009).

\subsection{Reensamblaje del aparato de Golgi en telofase.}

El reensamblaje del aparato de Golgi es esencialmente el proceso inverso al desensamblaje. En el reensamblaje del aparato de Golgi al final de la mitosis, tienen lugar dos fenómenos: la activación de la fusión de membranas y el reensamblaje de las cisternas. Además, en este proceso juegan un papel fundamental las fosfatasas, que son necesarias para que se reensamblen las nuevas cisternas formadas.

Los procesos de fusión de membranas que llevan al crecimiento de estas son llevados a cabo de modo secuencial por los complejos proteicos de las ATPasas NSF y VCP (Acharya et al., 1995; Rabouille et al., 1995; Rabouille et al., 1998).

En la fusión dependiente de la ATPasa NSF participan las golgins p115 y GM130 y los complejos SNARE (GOS-28/Syntaxin-5). La proteína p115 es clave tanto para el crecimiento de las membranas como para el posterior reensamblaje de las cisternas a través de la formación de complejos GM130-p115-Giantina (Rabouille et al., 1995; Rabouille et al., 1998; Sonnichsen et al., 1998; Shorter and Warren, 1999). 
En el caso de la ruta de la ATPasa VCP, se han descrito tres cofactores que están implicados en la fusión de membranas del aparato de Golgi en telofase: p47, p37 y VCIP135 (Kondo et al., 1997; Uchiyama et al., 2002; Uchiyama et al., 2006). En la fusión de las membranas del aparato de Golgi dependiente del cofactor p47, se forma un complejo transitorio VCP-p47-VCIP135 que se une a la proteína t-SNARE denominada Syntaxin-5. Este complejo se disocia tras la hidrólisis del ATP por VCP, permaneciendo la interacción VCP-VCIP135 (Rabouille et al., 1998; Uchiyama et al., 2002). Además, en la dinámica del aparato de Golgi en mitosis, hay un nivel más de regulación por monoubiquitinación en los que p47, que une monoubiquitina, y VCIP135, que es una enzima deubiquitinasa, están directamente implicados (Meyer et al., 2002; Wang et al., 2004b). Así, se piensa que el grado de ubiquitinación del aparato de Golgi sirve como señal para el desensamblaje/reensamblaje de este en mitosis y se propone que determinadas proteínas, hasta el momento desconocidas, son ubiquitinadas durante la fragmentación y deubiquitinadas durante el reensamblaje (Wang et al., 2004b) (Figura 19). El otro cofactor que participa en los procesos de fusión dependientes de VCP es p37. El complejo VCP-p37-VCIP135 interacciona con la proteína t-SNARE denominada GS-15. Además, al igual que en la ruta de NSF, en este proceso participa la proteína $\mathrm{p} 115$. En este caso, la actividad deubiquitinasa no es necesaria, ya que p37 carece de un dominio UBA. Por tanto, la actividad del complejo VCP-p37 no está relacionada con la ubiquitinación (Uchiyama et al., 2006).

En cuanto a los procesos de desfosforilación, se ha demostrado que la fosfatasa PP2A $(\mathrm{B} \alpha)$ (Protein Phosphatase $2 A$ ) es responsable de la desfosforilación de las proteínas GM130 y GRASP65 (Lowe et al., 2000; Tang et al., 2008). PP2A funciona como un trímero in vivo que se caracteriza por su complejo catalítico (AC) y la unión de una subunidad reguladora. Así, se ha encontrado que la subunidad reguladora $\mathrm{B} \alpha$ se localiza en el aparato de Golgi y es la responsable de la desfosforilación de las proteínas localizadas allí (Lowe et al., 2000). Las proteínas GM130 y GRASP65 sufren un ciclo de fosforilación/desfosforilación que regula la dinámica del aparato de Golgi en división celular (Lowe et al., 2000; Wang et al., 2003b; Tang et al., 2008). Además, se ha propuesto que otras proteínas también sufren este ciclo. Así, por ejemplo, p47 es fosforilada al inicio de mitosis por Cdc2 y se supone que se desfosforila en telofase, aunque no existen datos sobre la fosfatasa responsable (Uchiyama et al., 2003).

Una vez que las membranas han crecido lo suficiente por mecanismos de fusión se tiene que producir el reensamblaje de las cisternas para establecer el 
sistema continuo y apilado de membranas que es el aparato de Golgi en interfase. En el proceso de reensamblaje de las cisternas participan las proteínas p115, GM130, Giantina, GRASP55 y GRASP65 (Rabouille et al., 1995; Shorter and Warren, 1999; Shorter et al., 1999; Wang et al., 2008b; Xiang and Wang, 2010). p115 inicia el reensamblaje mediante su interacción con la proteína GM130 (una vez desfosforilada) y la proteína Giantina de otra cisterna (Sonnichsen et al., 1998). Además, la fosforilación de p115 (Ser941) por la quinasa CKII (Casein Kinase II) o CKII-Like kinase favorece la interacción Giantina-GM130 y, por tanto, el reensamblaje (DiracSvejstrup et al., 2000). Por último, se produciría la oligomerización de GRASP65 en trans, para lo que es necesario que se haya desfosforilado por la fosfatasa PP2A (B $\alpha$ ) y posiblemente ocurra lo mismo con GRASP55 aunque no existen datos sobre su desfosforilación (Wang et al., 2003b; Wang et al., 2008b).

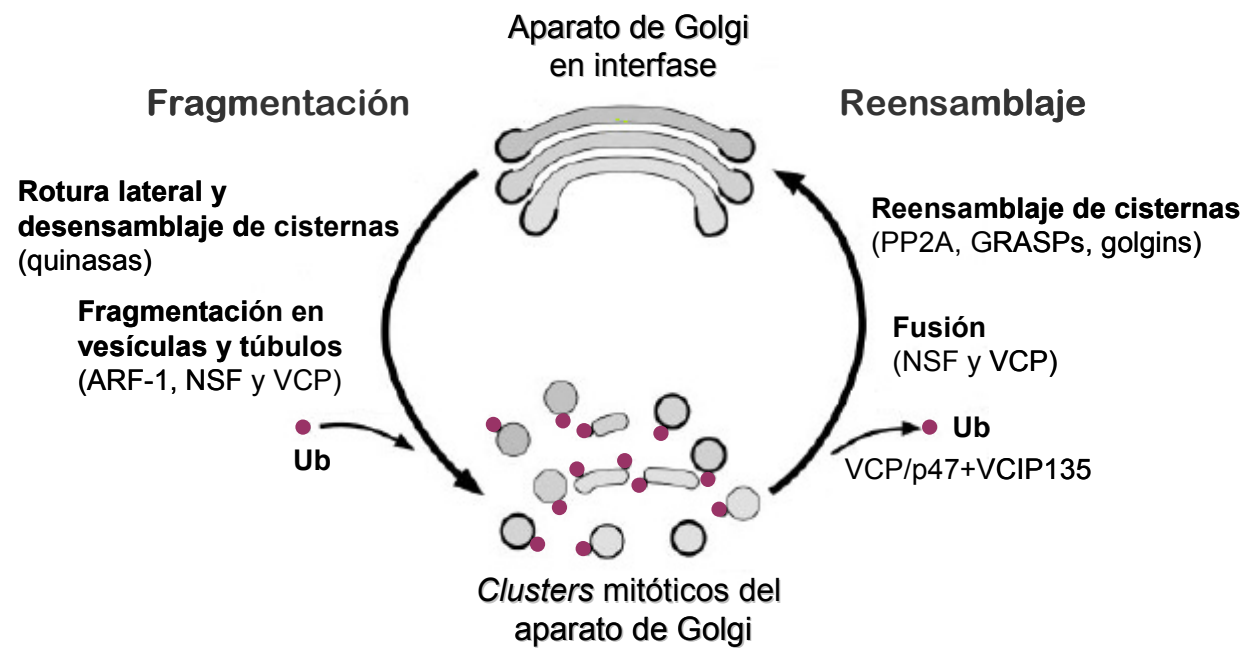

Figura 19. Ilustración que resume los procesos y proteínas implicadas en el desensamblaje/reensamblaje del aparato de Golgi en mitosis. En el proceso de fragmentación del aparato de Golgi tienen lugar varios acontecimientos: la rotura de las uniones laterales, el desensamblaje de las cisternas y la fragmentación de estas hasta dar lugar a vesículas y túbulos. Aquí participan varias quinasas (p. ej., MEK1, Plk1 y Cdc2), la GTPasa ARF-1 y las ATPasas NSF y VCP. En telofase, las membranas del aparato de Golgi se fusionan y se reensamblan. En estos procesos participan las ATPasas NSF y VCP, la fosfatasa PP2A y proteínas de la matriz del AG. Además, el AG sufre un ciclo de ubiquitinación/deubiquitinación (Ub) en mitosis. AG- aparato de Golgi. Adaptado de Tang et al., 2008.

La dinámica del aparato de Golgi en división celular es un proceso muy regulado y coordinado con la progresión de la mitosis y necesita de la cooperación de diversos elementos moleculares que incluyen quinasas, proteínas estructurales del aparato de Golgi, GTPasas y ATPasas, entre otros. Uno de los mecanismos clave en la 
regulación de la dinámica de este orgánulo es la fosforilación. Tal es la situación, que se han descrito diversas proteínas del aparato de Golgi que sufren un ciclo de fosforilación/desfosforilación que señaliza la dinámica del aparato de Golgi en división celular. Hasta el momento se han encontrado algunas de las quinasas implicadas, aunque posiblemente haya muchas más. Así, el establecimiento y caracterización de nuevos elementos en estas rutas de señalización ayudará a una mejor comprensión de los mecanismos de regulación que ocurren en este proceso.

En la figura 19 se resumen los fenómenos que tienen lugar en la fragmentación y el reensamblaje del aparato de Golgi en mitosis. 



\section{Objetivos}

$\sum$ Identificar y caracterizar subpoblaciones intracelulares de la quinasa humana VRK1.

$\sum$ Estudiar la relación de la quinasa Plk3 con VRK1 y analizar su implicación en la dinámica del aparato de Golgi en división celular. 

Resultados 



\section{Características de la quinasa VRK1 endógena.}

\subsection{Localización subcelular de VRK1.}

La quinasa VRK1 se caracteriza por una expresión ubicua en todos los tejidos y líneas celulares analizadas, tal y como muestran los datos de expresión de ARN mensajero (Nezu et al., 1997). En cuanto a su localización subcelular, inicialmente fue descrita como una proteína nuclear, excluida o no del nucleolo (Lopez-Borges and Lazo, 2000; Vega et al., 2004). Estudios posteriores aportaron datos sobre la localización de VRK1 en tejidos donde se determinó que era nuclear en carcinoma de cabeza y cuello y en carcinoma de pulmón, utilizando un anticuerpo policlonal (VC) para la tinción (Santos et al., 2006; Valbuena et al., 2007b). Para analizar más en detalle la localización subcelular de la quinasa VRK1, se tiñeron diferentes cortes de tejidos epiteliales normales, provenientes de biopsias humanas, mediante inmunohistoquímica utilizando dos anticuerpos diferentes, uno policlonal (VC) y otro monoclonal (1F6). En algunos de estos tejidos, como esófago y testículo, se observó una localización prácticamente nuclear, indistintamente del anticuerpo utilizado (Figura 20).

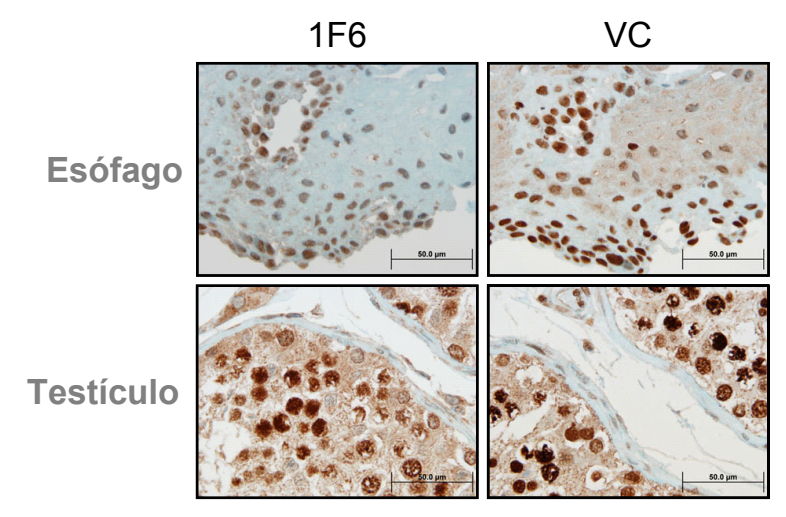

Figura 20. Localización de VRK1 humana en tejidos de esófago y testículo. Se realizó tinción inmunohistoquímica de cortes de tejido de esófago y testículo con dos anticuerpos distintos para VRK1, uno monoclonal (1F6) y otro policlonal (VC). La barra indica $50 \mu \mathrm{m}$.

Sin embargo, en la mayoría de los tejidos estudiados, se obtuvieron diferentes resultados según el anticuerpo utilizado. Así, el anticuerpo policlonal (VC) muestra una tinción principalmente nuclear, mientras que, el anticuerpo monoclonal (1F6) detecta a la quinasa VRK1 en el citoplasma y en algunos de los tejidos la tinción no es homogénea, sino que determina un agregado cercano al núcleo (Figura 21). Así, por ejemplo, en tejidos de cérvix e intestino delgado se puede observar dicho agregado 
localizado en la zona perinuclear (Figura 21, indicado con flechas rojas), mientras que en tejidos de mama y riñón el citoplasma se tiñe por completo.

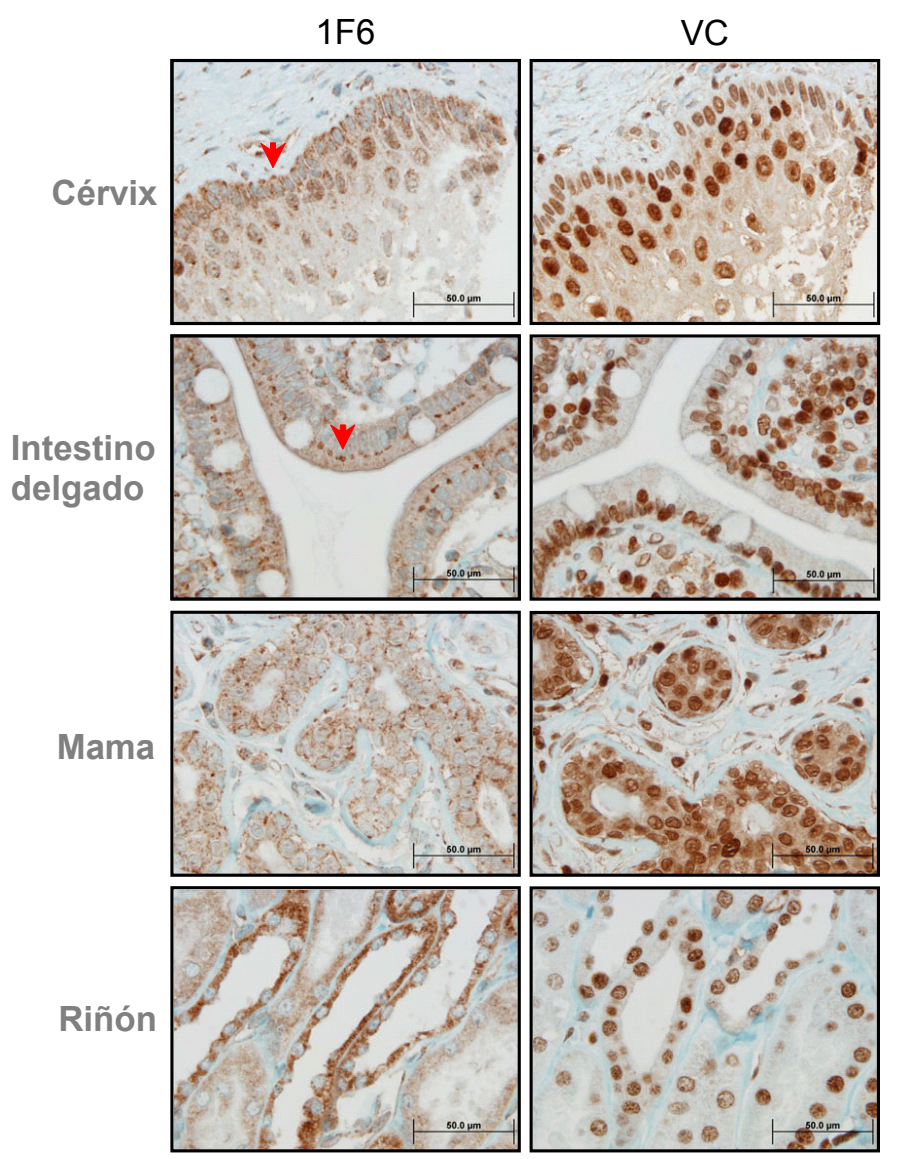

Figura 21. La localización de VRK1 varía según el anticuerpo utilizado en diversos tejidos. Se realizó tinción inmunohistoquímica de diferentes cortes de tejido con dos anticuerpos distintos para VRK1, uno monoclonal (1F6) y otro policlonal (VC). Las flechas rojas señalan un agregado perinuclear. La barra indica $50 \mu \mathrm{m}$.

Una vez determinada la localización de VRK1 a nivel de tejido, se analizó mediante inmunofluorescencia si en células en cultivo se observaban también distintas subpoblaciones de la quinasa VRK1 utilizando estos mismos anticuerpos. Para ello, se hicieron dobles tinciones con los anticuerpos 1F6 (en verde) y VC (en rojo) en las líneas celulares HeLa (adenocarcinoma de cérvix), MCF-7 (adenocarcinoma de mama) y H1299 (cáncer de pulmón de célula no pequeña) (Figura 22). El anticuerpo policlonal VC identifica en las líneas celulares HeLa y H1299 una subpoblación principalmente nuclear, confirmando lo descrito con anterioridad (Vega et al., 2004). Sin embargo, el anticuerpo 1F6 detecta a VRK1 en el citoplasma en todas las líneas celulares analizadas y, además, en HeLa y H1299 determina un agregado en la zona perinuclear. Cabe resaltar que en el caso de la línea celular MCF-7, pese a que ambos anticuerpos identifican a la proteína VRK1 en el citoplasma, sus señales no solapan. 
Por tanto, la quinasa humana VRK1 se encuentra tanto en el núcleo como en el citoplasma y las distintas subpoblaciones se detectan utilizando diferentes anticuerpos, lo que sugiere que estos reconocen epítopos distintos. Además, la presencia de VRK1 en dos contextos tan diferentes tiene importantes implicaciones biológicas en cuanto a sus dianas de fosforilación y las rutas de señalización en las que puede estar involucrada, lo que implica que su localización debe estar estrictamente regulada aunque los factores o el mecanismo son desconocidos.

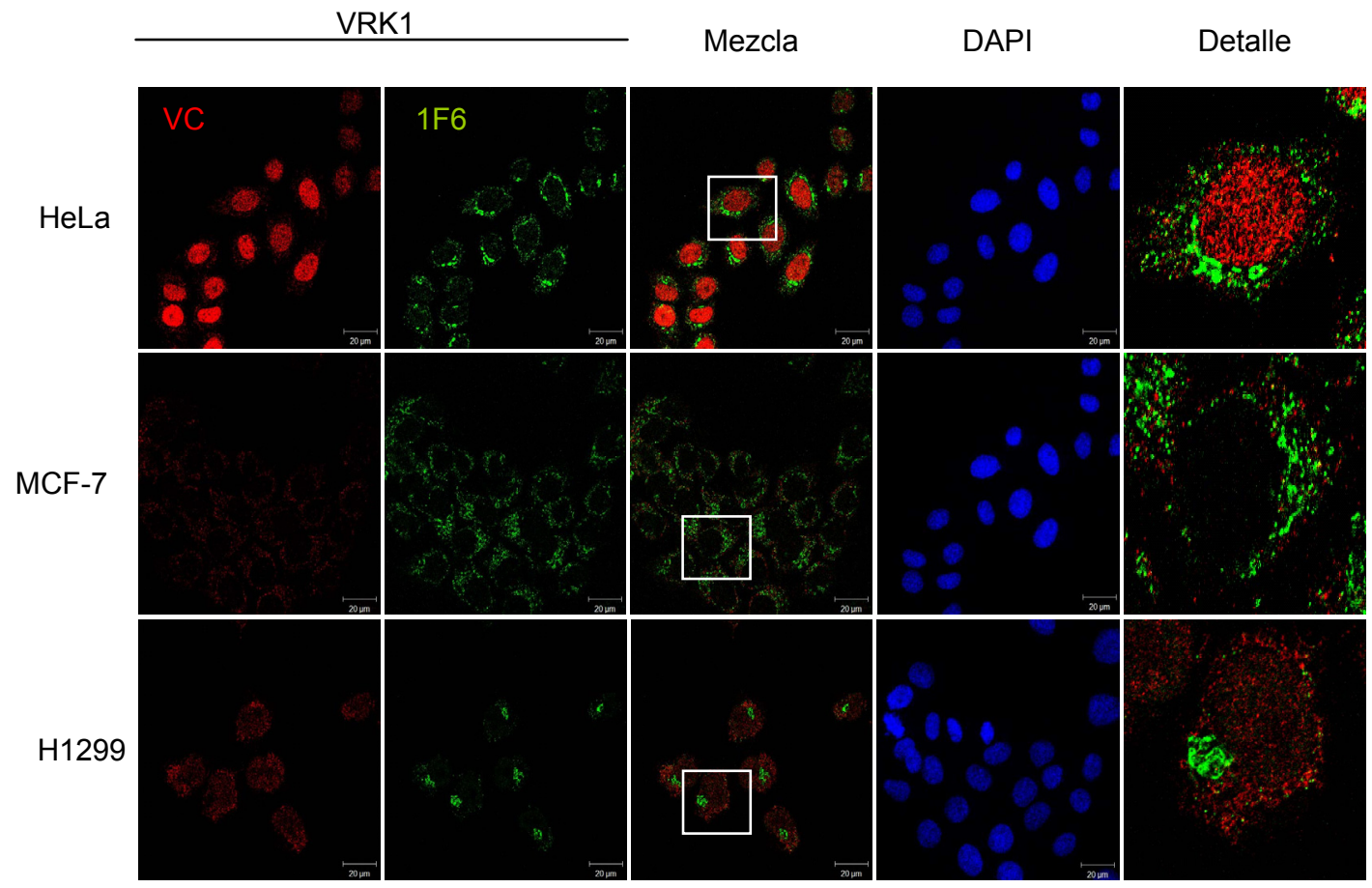

Figura 22. Localización de VRK1 en tres líneas celulares distintas. VRK1 es detectó con dos anticuerpos, uno policlonal (VC- rojo) y otro monoclonal (1F6- verde). El ADN se tiñó con DAPI (azul). Se muestra en detalle una célula para ver el solapamiento de las señales de ambos anticuerpos. La barra indica $20 \mu \mathrm{m}$.

En algunos casos, se observa a VRK1 en el nucleolo que es un orgánulo localizado en el núcleo cuya función es la biogénesis de los ribosomas, lo que está estrechamente relacionado con el crecimiento celular, la proliferación e incluso con la regulación del ciclo celular (Vega et al., 2004; Andersen et al., 2005; Sirri et al., 2008). Para analizar en más detalle esta subpoblación de VRK1, se transfectaron células HeLa con oligonucleótidos de ARN de interferencia específicos para VRK1 (siVRK1) u oligos sin diana específica como control negativo (siControl) con el fin de disminuir el nivel de expresión de VRK1 y comprobar el efecto sobre distintas subpoblaciones de la quinasa. La eficiencia de los oligos para VRK1 había sido demostrada con anterioridad 
(Vega et al., 2004). A continuación, las células se fijaron y se tiñeron para inmunofluorescencia (Figura 23).

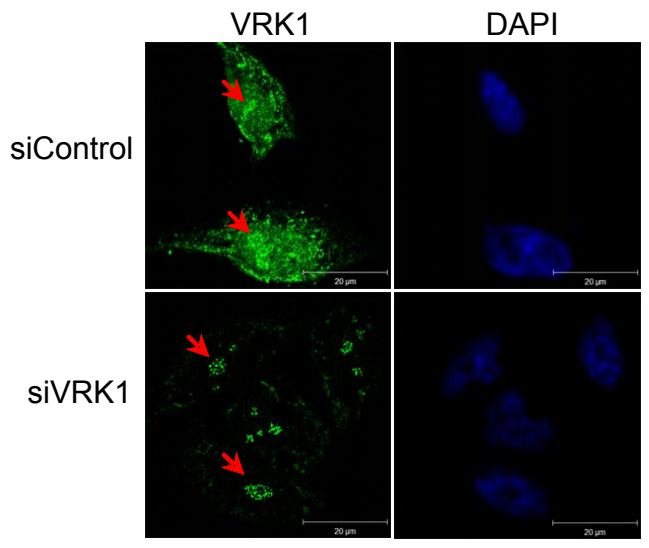

Figura 23. Localización de VRK1 respecto al nucleolo. Localización de VRK1 (H1verde) y el ADN (DAPI- azul) en la línea celular HeLa. Las células fueron tratadas con siControl o ARN de interferencia específico para VRK1 durante 4 días. Las flechas rojas señalan el nucleolo. La barra indica $20 \mu \mathrm{m}$.

Bajo estas condiciones, se detectó la subpoblación del nucleolo con un anticuerpo policlonal denominado $\mathrm{H} 1$, tanto en células tratadas con siControl como en células tratadas con siVRK1 (Figura 23, indicado con flechas). Sin embargo, de las subpoblaciones de VRK1 detectadas con el anticuerpo $\mathrm{H} 1$, la población que permanece intacta tras cuatro días de tratamiento con siVRK1 es aquella localizada en el nucleolo. Esto parece indicar que la subpoblación de VRK1 asociada al nucleolo es más estable (al menos al tratamiento con ARN de interferencia) que las subpoblaciones localizadas en el nucleoplasma y en el citoplasma. La posible función y regulación de la quinasa VRK1 asociada al nucleolo es por el momento desconocida.

\subsection{El anticuerpo 1F6 identifica una subpoblación de VRK1 en el aparato de Golgi.}

De todas las localizaciones subcelulares encontradas para la quinasa VRK1, se decidió centrar el estudio en aquella detectada con el anticuerpo monoclonal 1F6 que determina una estructura en la zona perinuclear. Teniendo en cuenta las características del agregado, se pensó que podría tratarse del aparato de Golgi ya que este orgánulo se caracteriza en interfase por constituir un sistema continuo de membranas localizado en la región perinuclear del citoplasma cerca del centrosoma (Ladinsky et al., 1999).

Para determinar si este era el caso, se realizaron ensayos de colocalización en varias líneas celulares utilizando como marcador del aparato de Golgi la proteína Giantina, que se caracteriza por ser una proteína integral de membrana de unos 375 
$\mathrm{KDa}$ con un gran dominio citoplasmático y una localización en cis/medial-Golgi (Linstedt and Hauri, 1993; Linstedt et al., 1995).

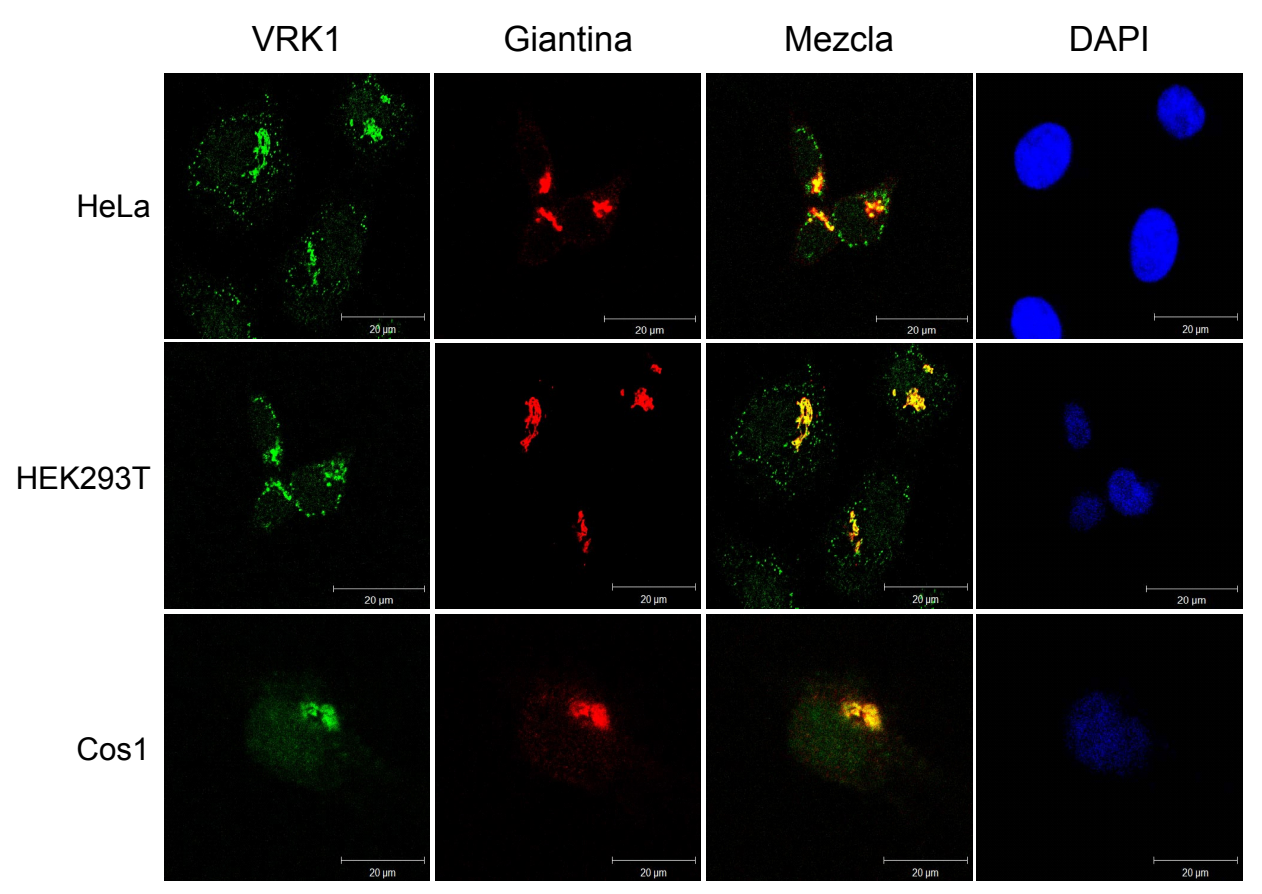

Figura 24. Localización de VRK1 con respecto al aparato de Golgi en varias líneas celulares. VRK1 se detectó con un anticuerpo monoclonal (1F6- verde) que marca la subpoblación en el aparato de Golgi y dicho orgánulo se detectó con un anticuerpo policlonal para Giantina (rojo). El ADN se tiñó con DAPI (azul). La barra indica $20 \mu \mathrm{m}$.

En la figura 24, se aprecia cómo en todas las líneas celulares existe colocalización (señal amarilla) de la subpoblación de VRK1 (en verde) y el cis/medialGolgi identificado por la proteína Giantina (en rojo). A pesar de que existe un alto grado de colocalización, también se detecta cierta proporción de VRK1 en el citoplasma fuera de lo marcado como aparato de Golgi.

Para confirmar que, efectivamente, existe una proporción de VRK1 asociada al aparato de Golgi se realizaron dos tipos de fraccionamiento subcelular. En un primer ensayo, se llevó a cabo un fraccionamiento citoplasma-membranas en el que se obtuvieron tres fracciones: el lisado total $(\mathrm{L})$, la fracción citoplasmática $(C)$ y la fracción de membranas (M) (Figura 25A). Como marcador del aparato de Golgi se usó una proteína de menor tamaño denominada GM130, cuyo peso molecular son $130 \mathrm{KDa}$. Se hizo de este modo con objeto de poder detectar ambas proteínas bajo las mismas condiciones de electroforesis y transferencia. Al analizar por inmunoblot la presencia de VRK1 en las distintas fracciones, se detectó en todas ellas, mientras que la proteína GM130 quedó restringida a la fracción de membranas (M). 
En un segundo ensayo, se realizó un fraccionamiento específico para el aislamiento de membranas del aparato de Golgi. Para ello, el lisado de células A549 (carcinoma de pulmón) se sometió a un gradiente discontinuo de sacarosa (1,4 M-1,2 $\mathrm{M}-0,8 \mathrm{M}$ ) del que se recogieron fracciones de $2 \mathrm{ml}$ en torno a la zona correspondiente a la densidad del aparato de Golgi (zona 1,2 M-0,8 M de sacarosa) (Balch et al., 1984). A continuación, se precipitaron las fracciones y se llevó a cabo un inmunoblot para analizar las proteínas contenidas en las fracciones. Como se observa en la figura 25B, la quinasa VRK1 y la proteína K58, utilizada como marcador de las membranas del aparato de Golgi, son detectadas juntas en varias fracciones (fracciones 3, 4, 5, 6, 7, y 8), que se corresponden con membranas del aparato de Golgi. Además, VRK1 también se observa en otras fracciones, tal y como se espera debido a sus diferentes localizaciones subcelulares.

B

A

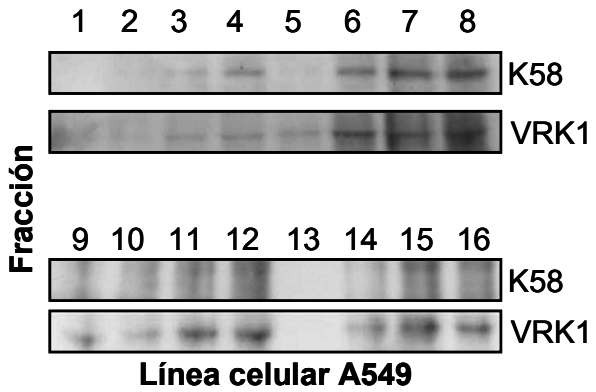

Figura 25. Aislamiento de la población de VRK1 asociada al aparato de Golgi. A) Fraccionamiento subcelular citoplasma-membranas. Se detectó VRK1 con un anticuerpo policlonal (VC) y las membranas del aparato de Golgi con un anticuerpo monoclonal para GM130. L- Lisado total; C- Fracción citoplasmática; M- Fracción de membranas. B) Aislamiento del aparato de Golgi por gradiente discontinuo de sacarosa. VRK1 fue detectada con el anticuerpo 1F6 y las membranas del aparato de Golgi con un anticuerpo frente a la proteína K58.

Puesto que el retículo endoplasmático se localiza en la zona perinuclear y está estrechamente relacionado con el aparato de Golgi, se analizó si la subpoblación de VRK1 identificada por el anticuerpo 1F6 tenía o no exclusivamente una localización asociada a membranas del aparato de Golgi. Para ello, se tiñeron células A549 con el anticuerpo 1F6 (en verde) y el retículo endoplamático se marcó con un anticuerpo frente a la proteína Calreticulina (en rojo). Como se aprecia en la figura 26, no existe solapamiento en la señal, lo que confirma que la localización de VRK1 observada mediante el anticuerpo 1F6 es del aparato de Golgi.

Por tanto, se puede concluir que el anticuerpo 1F6 identifica por inmunofluorescencia una subpoblación de VRK1 asociada al aparato de Golgi y que 
esta subpoblación, se detecta junto con membranas del aparato de Golgi mediante técnicas de fraccionamiento subcelular.

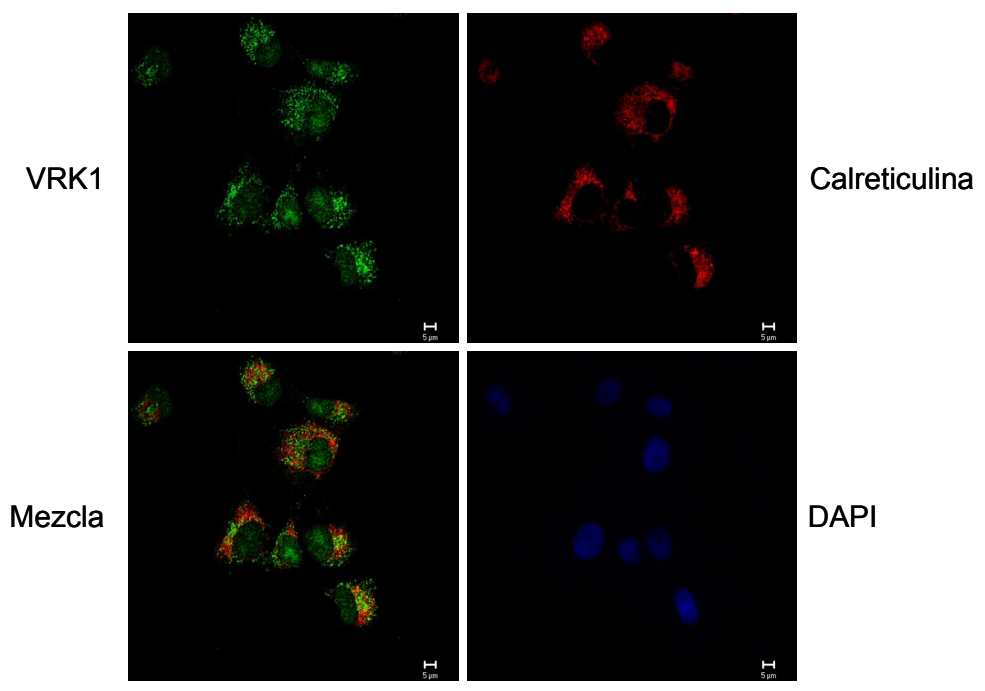

Figura 26. Localización de VRK1 respecto al retículo endoplasmático. Localización de VRK1 (1F6- verde), el retículo endoplasmático (Calreticulina- rojo) y el ADN (DAPI- azul) en la línea celular A549. La barra indica $5 \mu \mathrm{m}$.

\subsection{Localización de VRK1 a lo largo del ciclo celular.}

La división celular implica un reparto entre las dos células hijas tanto del material genético como de los orgánulos citoplasmáticos. Aquellos orgánulos que existen en la célula como una única copia (como es el caso del aparato de Golgi) se fragmentan al inicio de la mitosis para repartirse entre las dos células hijas y se reensamblan de nuevo en telofase (Shorter and Warren, 2002).

Tratando de ir más allá en la caracterización de esta quinasa y, más concretamente, con respecto a la subpoblación asociada al aparato de Golgi, se llevó a cabo un seguimiento de su localización a lo largo de la mitosis.

En un primer ensayo, se tiñeron células HeLa con el anticuerpo monoclonal 1F6 para VRK1 (en verde) y un anticuerpo policlonal para Giantina (en rojo). La identificación de cada fase del ciclo celular se hizo utilizando el DAPI que tiñe el ADN (en azul). Se decidió utilizar la línea celular HeLa ya que gran parte de los estudios relacionados con el aparato de Golgi y la división celular se han realizado en esta línea celular.

El aparato de Golgi sufre la primera modificación al final de la fase G2, pero esta rotura lateral de las cisternas no es detectable por inmunofluorescencia. Ya en profase, las cisternas del aparato de Golgi empiezan a desensamblarse y a fragmentarse en vesículas y túbulos dando lugar a 35-45 fragmentos de un tamaño 
aproximado de 1-3 $\mu \mathrm{m}$ en HeLa (Shima et al., 1998). La fragmentación continúa hasta alcanzar su máximo en metafase, donde el tamaño de las vesículas y de los túbulos varía entre 0,25-1 $\mu \mathrm{m}$ (Shima et al., 1997) y da lugar a lo que se denomina el Golgi mitotic haze, que se podría traducir como "neblina del aparato de Golgi en mitosis", y que se llama así porque el grado de fragmentación de las membranas es tal, que las proteínas se detectan como una "neblina" alrededor de la placa metafásica (Jokitalo et al., 2001). A partir de aquí, al iniciarse la segregación de los cromosomas en anafase, las membranas del aparato de Golgi comienzan a crecer y fusionarse. Ya en telofase, se pueden detectar dos subpoblaciones de membranas, cada una de ellas asociada a uno de los polos del huso mitótico (Shima et al., 1998; Seemann et al., 2002; Wei and Seemann, 2009c).

Como se observa en la figura $27 \mathrm{~A}$ en el panel de interfase, la señal de la proteína VRK1 identificada con el anticuerpo 1F6 solapa casi completamente con las membranas del aparato de Golgi marcadas con Giantina, como se determinó en ensayos anteriores. Además, a lo largo de las distintas fases de la mitosis también se detecta colocalización. Es decir, a medida que el aparato de Golgi va fragmentándose desde profase hasta metafase, se observa solapamiento de la señal que va desde un único agregado hasta el Golgi mitotic haze, donde la dispersión de VRK1 es máxima. En anafase-telofase, VRK1 comienza a reagruparse en dos claras subpoblaciones que rodean los polos del huso mitótico, al igual que las membranas del aparato de Golgi, para terminar dando lugar a un único agregado.

Para analizar en mayor profundidad el grado de colocalización de VRK1 respecto al aparato de Golgi, se realizó su cuantificación utilizando el programa ImageJ (http: rsb.info.nih.gov/ii). Se usaron tres métodos distintos: el coeficiente de correlación de Pearson ( $R r$, con valores entre $-1 \mathrm{y}+1)$, el coeficiente de Mander $(R$, con valores entre cero y +1) y el grado de correlación de la intensidad (ICQ, con valores entre $-0,5 y+0,5)$. Ya que ninguno de los métodos es perfecto, se deben tener en cuenta en su conjunto. En todos los casos, una buena correlación viene dada por un valor máximo positivo de cada coeficiente. Como se puede ver en la figura $27 \mathrm{~B}$, en todos los casos, los valores son positivos y, en su conjunto, demuestran que la correlación que existe entre la distribución de VRK1 y las membranas del aparato de Golgi no es aleatoria.

Posteriormente, se llevó a cabo un segundo ensayo donde se tiñeron células HeLa con un anticuerpo policlonal para VRK1 (VC- verde) y las membranas del aparato de Golgi con un anticuerpo monoclonal para la proteína GM130 (en rojo). 
A

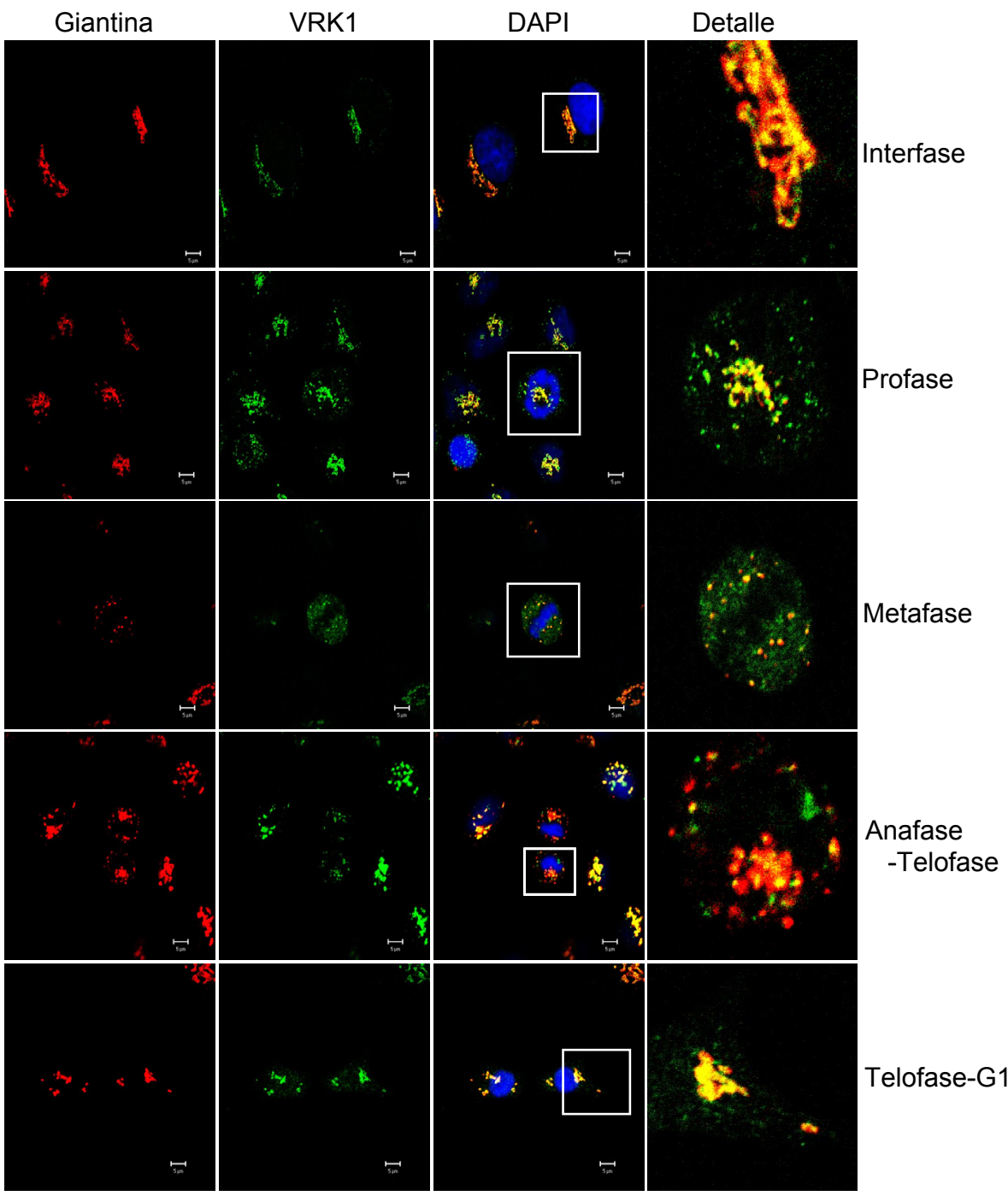

B

\begin{tabular}{|c|c|c|c|}
\hline $\begin{array}{c}\text { Fase del } \\
\text { ciclo }\end{array}$ & $\mathbf{R r}$ & $\mathbf{R}$ & $\mathbf{I C Q}$ \\
\hline Interfase & 0,742 & 0,854 & 0,375 \\
\hline Profase & 0,644 & 0,749 & 0,317 \\
\hline Metafase & 0,256 & 0,429 & 0,188 \\
\hline $\begin{array}{c}\text { Anafase- } \\
\text { Telofase }\end{array}$ & 0,402 & 0,569 & 0,239 \\
\hline Telofase- G1 & 0,762 & 0,866 & 0,386 \\
\hline
\end{tabular}

Figura 27. Localización de la subpoblación de VRK1 en el aparato de Golgi en el ciclo celular. A) Localización de VRK1 (1F6- verde), el aparato de Golgi (Giantina- rojo) y el ADN (DAPI- azul) en las distintas fases de la mitosis. La barra indica $5 \mu \mathrm{m}$. B) Medida cuantitativa del grado de colocalización de VRK1 y el aparato de Golgi a lo largo de la mitosis. Rr- coeficiente de correlación de Pearson; R- coeficiente de Mander; ICQ- grado de correlación de la intensidad. Se indican los valores obtenidos para las imágenes del apartado $A$. 
Como se puede observar en la figura 28, la subpoblación de VRK1 detectada con el anticuerpo VC en interfase es nuclear (Vega et al., 2004) y no solapa su señal con el aparato de Golgi ni en interfase ni a lo largo de la mitosis. De hecho, en metafase, tanto VRK1 como la señal de las membranas del aparato de Golgi están completamente difuminadas y, aún así, no colocalizan. En telofase, se vuelve a distinguir VRK1 en su localización nuclear, mientras que el aparato de Golgi se va reensamblando de nuevo.

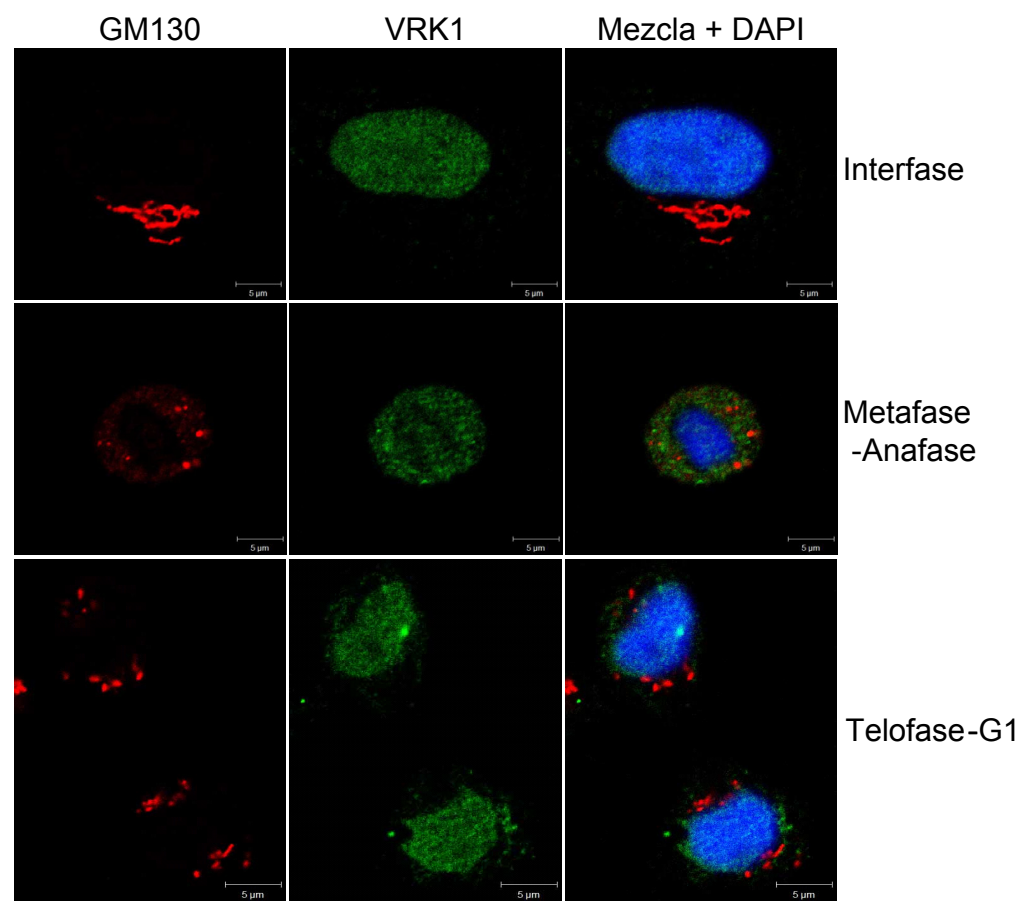

Figura 28. Localización de la subpoblación de VRK1 nuclear respecto al aparato de Golgi en mitosis. Localización de VRK1 (VC- verde), el aparato de Golgi (GM130- rojo) y el ADN (DAPIazul) en distintas fases del ciclo celular. La barra indica $5 \mu \mathrm{m}$.

\section{VRK1 y PIk3.}

Hasta ahora se han descrito proteínas diana de VRK1 que la sitúan en diferentes rutas de señalización. Dentro de estos sustratos están, por ejemplo, p53, ATF-2, c-Jun y BAF (Lopez-Borges and Lazo, 2000; Sevilla et al., 2004a; Sevilla et al., 2004b; Nichols et al., 2006). Sin embargo, para una mejor comprensión de la función biológica de esta quinasa, además de conocer sus sustratos, es necesario identificar sus reguladores. Además, considerando los diferentes patrones de localización subcelular observados, quizás la determinación de proteínas upstream de VRK1, permita la identificación de funciones asociadas a dichas localizaciones. Por ello, uno de los objetivos de este 
trabajo fue la búsqueda de proteínas situadas por encima de VRK1 susceptibles de regularla e implicarla en nuevas rutas de señalización. Por esta razón, se decidió hacer uso de un programa de predicción de secuencias consenso denominado ELM (Eukaryotic Linear Motif) (Puntervoll et al., 2003).

\subsection{Análisis de la secuencia de VRK1 por ELM.}

El programa ELM es una herramienta bioinformática que identifica posibles motivos funcionales no globulares de secuencia corta. Este tipo de motivos son clave en las proteínas para determinar interacciones proteína-proteína, regulación por fosforilación, acetilación y otras modificaciones postraduccionales. Cuenta con una serie de filtros para disminuir el número de falsos positivos. Uno de ellos es un filtro de dominios globulares identificados mediante las bases de datos SMART y Pfam (Bateman et al., 2002; Letunic et al., 2002). Así, todas aquellas secuencias identificadas dentro del dominio globular de la proteína analizada son descartadas, ya que la posibilidad de que sean funcionales es baja (Puntervoll et al., 2003).

En la figura 29 se muestra un resumen de los resultados obtenidos del análisis de la secuencia de aminoácidos de VRK1 mediante el programa ELM.

Dentro de los motivos consenso obtenidos hay dominios de interacción de proteínas, como, por ejemplo, una secuencia de unión a ciclinas (LIG_CYCLIN1). Sin embargo, para tener en consideración este motivo funcional se tendría que haber identificado también una secuencia de fosforilación por CDKs (MOD_CDK). También hay dos tipos de secuencia consenso de ligando que interaccionan con dominios $\mathrm{SH} 2$ (LIG_SH2_GRB2 y LIG_SH2_STAT5). Los dominios SH2 se caracterizan por reconocer e interaccionar con pequeñas secuencias consenso de proteínas ligando que tienen tirosinas fosforiladas. Por último, se predicen dos secuencias consenso de ligando más: LIG_PDZ3 y LIG_FHA. La primera es reconocida por dominios PDZ (clase III) y la segunda por dominios FHA-1. En este último caso, aquellas proteínas que contienen dominios FHA-1 reconocen e interaccionan con secuencias consenso de proteínas ligando que tienen una treonina fosforilada.

El análisis de VRK1 también predijo dos secuencias señal (TRG ENDOCYTIC 2 y TRG LysEnd APsAcLL1) y varias secuencias consenso de modificaciones postraduccionales (MOD_CK2_1, MOD_PKA_2, MOD_PLK y MOD_SUMO).

Teniendo en cuenta que se buscaban posibles reguladores de VRK1, se consideraron de especial interés las secuencias consenso obtenidas para modificaciones postraduccionales. Además, resultados obtenidos por proteómica, que 
se explicarán más adelante, junto con los resultados relacionados con el patrón de localización de la quinasa VRK1, hicieron posible restringir el estudio en torno a la familia de quinasas Plk.

\begin{tabular}{|c|c|c|c|}
\hline Nombre ELM & Secuencia & Posición & Descripción \\
\hline LIG_CYCLIN_1 & $\begin{array}{l}\text { KLLDY } \\
\text { KPLY }\end{array}$ & $\begin{array}{l}307-311 \\
314-317\end{array}$ & sitio funcional de interacción con ciclinas \\
\hline LIG_FHA_1 & $\begin{array}{l}\text { TDMA } \\
\text { TVKL } \\
\text { TEEA }\end{array}$ & $\begin{array}{c}30-33 \\
305-308 \\
380-383\end{array}$ & $\begin{array}{l}\text { dominio de interacción } \mathrm{FHA}-1 \text { que } \\
\text { requiere fosforilación en treonina }\end{array}$ \\
\hline LIG_PDZ_3 & $\begin{array}{l}\text { GEII } \\
\text { YENL } \\
\text { RDIL } \\
\text { EEAI }\end{array}$ & $\begin{array}{c}26-29 \\
317-320 \\
321-324 \\
381-384\end{array}$ & dominio de unión PDZ clase III \\
\hline LIG_SH2_GRB2 & YENL & $317-320$ & $\begin{array}{l}\text { dominio de unión GRB2-like Src } \\
\text { Homology } 2(\mathrm{SH} 2)\end{array}$ \\
\hline MOD_CK2_1 & $\begin{array}{l}\text { LDLSVVE } \\
\text { WSNTQTE }\end{array}$ & $\begin{array}{l}339-345 \\
375-381\end{array}$ & sitio de fosforilación por CK2 \\
\hline MOD_PKA_2 & GRQSSAK & $10-16$ & sitio de fosforilación por PKA \\
\hline MOD_PLK & LDLSVVE & $339-345$ & sitio de fosforilación de quinasas Plk \\
\hline $\begin{array}{l}\text { TRG_ENDOCYTIC } \\
2\end{array}$ & YENL & $317-320$ & $\begin{array}{l}\text { señal basada en tirosina de proteínas de } \\
\text { membrana responsable de la interacción } \\
\text { con la subunidad mu del complejo } \\
\text { adaptador AP que marca la ruta de } \\
\text { transporte intracelular y su destino final }\end{array}$ \\
\hline $\begin{array}{l}\text { TRG_LysEnd } \\
\text { APsAcLL_1 }\end{array}$ & ETVKLL & $304-309$ & $\begin{array}{l}\text { señal de internalización de proteínas } \\
\text { transmembrana tipo I responsable de la } \\
\text { interacción con complejos de proteínas } \\
\text { adaptadoras tipo AP o GGAs }\end{array}$ \\
\hline LIG_SH2_STAT5 & YTEK & $311-314$ & $\begin{array}{l}\text { dominio de unión STAT5 Src Homology } 2 \\
(\mathrm{SH} 2)\end{array}$ \\
\hline MOD_SUMO & AKKE & $33-34$ & $\begin{array}{l}\text { secuencia de reconocimiento para } \\
\text { sumoilación por SUMO-1 }\end{array}$ \\
\hline
\end{tabular}

Figura 29. Análisis de la secuencia de la quinasa humana VRK1 mediante el programa ELM. La secuencia de aminoácidos de VRK1 fue analizada mediante el programa ELM (http://elm.eu.org/). En la tabla se resumen los resultados obtenidos indicando el nombre específico en ELM, la posición de la secuencia consenso en VRK1, la secuencia consenso y una breve descripción del motivo funcional.

La familia de quinasas humanas Plk es bien conocida por sus diversas funciones en proliferación y ciclo celular (Barr et al., 2004). Está formada por cuatro miembros: Plk1, Plk2, Plk3 y Plk4. De todos ellos, se decidió centrar el estudio en Plk3, principalmente, por dos motivos: la identificación de Plk3 como proteína candidata a interaccionar con VRK1 mediante técnicas proteómicas y la existencia de una subpoblación de Plk3 asociada al aparato de Golgi tanto en interfase como en mitosis (Dai et al., 2002b; Ruan et al., 2004; Xie et al., 2004), tal y como ocurre con 
VRK1. De hecho, se pensó que quizás la quinasa Plk3 podría aportar alguna clave sobre la posible función de VRK1 en el aparato de Golgi.

En el análisis de la secuencia de VRK1, además de la secuencia consenso para la familia Plk mostrada en la figura 29, se identificó otra que se descartó por localizarse dentro del dominio globular de VRK1, que abarca aproximadamente lo que es el dominio quinasa de la proteína VRK1 (aminoácidos 35-275).

\subsection{Identificación de Plk3 como proteína candidata a interaccionar con VRK1 mediante técnicas proteómicas.}

En paralelo a este estudio, se estaba llevando a cabo en el laboratorio una aproximación experimental basada en la purificación de complejos de proteínas e identificación de las proteínas asociadas mediante espectrometría de masas (Monti et al., 2005). Para ello, se utilizó un vector de expresión en eucariotas pCEFL-GST-VRK1 que expresa la proteína VRK1 fusionada a GST y como control del ensayo el correspondiente vector vacío pCEFL-GST $\varnothing$. Los dos vectores fueron transfectados en la línea celular HEK293T (carcinoma de riñón) y, a continuación, se precipitaron (Pulldown) los complejos proteicos asociados a VRK1 mediante la resina Glutathion Sepharose, que se caracteriza por su afinidad por la GST de las proteínas de fusión. Este precipitado de proteínas se resolvió mediante electroforesis bidimensional. Para la separación de la mezcla de proteínas en la primera dimensión, se utilizó el isoelectroenfoque, usando un gradiente de $\mathrm{pH}$ 3-10 no lineal $\mathrm{y}$, en la segunda dimensión, un gel SDS-PAGE al $10 \%$ de acrilamida. Como resultado de la electroforesis bidimensional, las proteínas aparecen en el gel en forma de manchas circulares o spots. La selección de los spots se hizo comparando el gel de la muestra de interés (pCEFL-GST-VRK1) respecto del control (pCEFL-GSTØ). La identificación de los spots seleccionados, que serían posibles proteínas candidatas a interaccionar con VRK1, se realizó mediante el análisis de su huella peptídica (conjunto de péptidos generados mediante la digestión del spot con una proteasa), por espectrometría de masas utilizando un espectrómetro de masas MALDI-TOF.

Uno de los spots seleccionados $\left(n^{0} 17\right)$, se identificó mediante su huella peptídica como la quinasa humana Plk3. En la figura 30A se muestra el fragmento de gel correspondiente a la región del spot seleccionado que se identificó como Plk3 (panel derecho). Como se puede apreciar, este spot existe en el gel de la muestra de interés (GST-VRK1) y no se detecta en el control correspondiente (GSTØ). Este spot fue digerido con tripsina, lo que generó un conjunto de péptidos (huella peptídica) que 
se analizó mediante MALDI-TOF, generando un espectro de valores de masa experimentales (m/z) (Figura 30B). De los valores obtenidos, nueve fueron utilizados para la identificación de la proteína mediante el buscador MASCOT y solamente cuatro (número mínimo requerido para una asignación) fueron asignados a valores de masa de péptidos teóricos de Plk3. En el espectro (Figura 30B) se indica a qué picos corresponden los valores de masa $(\mathrm{m} / \mathrm{z})$ asignados. También se muestra la secuencia y posición de los péptidos. Los péptidos asignados corresponden a un $10 \%$ de la secuencia de Plk3 (Figura 30C). Para esta asignación se obtuvo un score de 39.

B

A

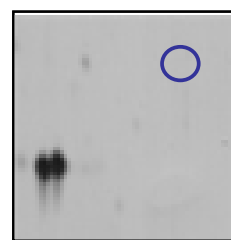

GSTØ

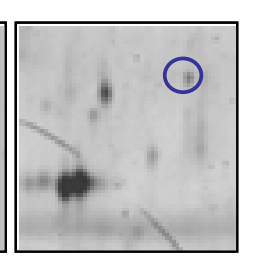

GST-VRK1

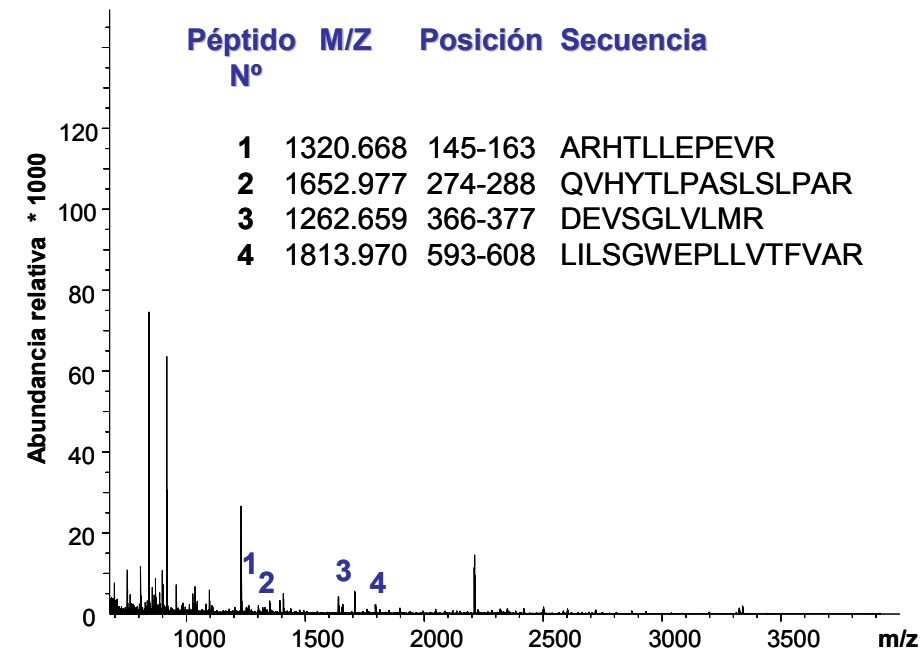

C

MEPAAGFLSP RPFQRAAAAP APPAGPGPPP SALRGPELEM LAGLPTSDPG RLITDPRSGR TYLKGRLLGK GGFARCYEAT DTETGSAYAV KVIPQSRVAK PHQREKILNE IELHRDLQHR HIVRFSHHFE DADNIYIFLE LCSRKSLAHI WKARHTLLEP EVRYYLROIL SGLKYLHORG ILHRDLKLGN FFITENMELK VGDFGLAARL EPPEQRKKTI CGTPNYVAPE VLLRQGHGPE ADVWSLGCVM YTLLCGSPPF ETADLKETYR CIKQVHYTLP ASLSLPARQL LAAILRASPR DRPSIDQILR HDFFTKGYTP DRLPISSCVT VPDLTPPNPA RSLFAKVTKS LFGRKKKSKN HAQERDEVSG LVSGLMRTSV GHQDARPEAP AASGPAPVSL VETAPEDSSP RGTLASSGDG FEEGLTVATV VESALCALRN CIAFMPPAEO NPAPLAOPEP LVWVSKWVDY SNKFGFGYOL SSRRVAVLFN DGTHMALSAN RKTVHYNPTS TKHFSFSVGA VPRALQPQLG ILRYFASYME QHLMKGGDLP SVEEVEVPAP PLLLQWVKTD QALLMLFSDG TVQVNFYGDH TKLILSGWEP LLVTFVARNR SACTYLASHL RQLGCSPDLR QRLRYALRLL RDRSPA

Figura 30. Identificación de PIk3 mediante técnicas proteómicas. A) Pulldown de proteínas asociadas a VRK1. Se transfectaron células HEK293T con $8 \mu \mathrm{g}$ de pCEFL-GST-VRK1 y $2 \mu \mathrm{g}$ de pCEFL-GST $\varnothing$ como control. 48 horas después, se precipitaron las proteínas asociadas a VRK1 con la resina Glutathion Sepharose. Este precipitado se resolvió por electroforesis bidimensional. El spot seleccionado (en azul) fue más tarde identificado como Plk3. B) Espectro de masas y péptidos asignados del spot seleccionado. Se muestra el espectro de masas obtenido y se señalan los péptidos del espectro que fueron asignados como péptidos teóricos de Plk3. Se indica el valor de la masa experimental $(\mathrm{m} / \mathrm{z})$, la secuencia de aminoácidos y la posición de los péptidos. C) Cobertura de la secuencia de PIk3. Se indica la posición exacta de los péptidos obtenidos en la secuencia de aminoácidos de Plk3 (subrayado y en azul).

En este estudio proteómico el buscador utilizado para la identificación de spots fue MASCOT (Perkins et al., 1999) y los parámetros establecidos asignaron que un 
score inferior a 54 no es estadísticamente significativo. Es decir, la identificación de Plk3 como proteína que interacciona con VRK1, bajo estas condiciones experimentales y metodológicas, no es estadísticamente significativa.

Sin embargo, teniendo en cuenta los datos obtenidos en el análisis de la secuencia de VRK1 por el programa ELM y las similitudes en la localización subcelular de Plk3 con respecto a VRK1, se decidió continuar con el estudio de la posible relación entre las quinasas VRK1 y PIk3.

\subsection{La quinasa PIk3 fosforila a VRK1 en serina 342.}

Tanto VRK1 como Plk3 son serina/treonina quinasas con una alta tasa de autofosforilación (Lopez-Borges and Lazo, 2000; Bahassi el et al., 2002). Además, la predicción de una secuencia consenso de fosforilación en VRK1 para proteínas Plk hizo pensar que la manera más inmediata de determinar si existía alguna relación entre ambas quinasas sería realizando un ensayo quinasa in vitro en presencia de $[\gamma$ $\left.{ }^{32} \mathrm{P}\right]$ ATP y proteínas purificadas unidas a GST.

Para ello, se utilizaron proteínas purificadas silvestres y mutantes sin actividad quinasa de ambas proteínas. Además, se incluyó un mutante no fosforilable en la serina $342\left(\mathrm{VRK}^{\mathrm{K} 179 \mathrm{E} / \mathrm{S} 342 \mathrm{~A}}\right)$, ya que ese es el residuo predicho como diana de la familia Plk en la secuencia consenso fuera del dominio globular de VRK1 (ver figura 32).

En la figura $31 \mathrm{~A}$ (panel superior), se muestra la autorradiografía $\left({ }^{32} \mathrm{P}\right)$ donde se detecta la autofosforilación de las quinasas silvestres (carriles 1 y 2) y la ausencia de actividad quinasa de los mutantes inactivos (carriles 6 y 7 ). Estos mutantes deben su inactividad a la sustitución de una lisina clave para la funcionalidad del dominio de unión al ATP típico de las proteínas quinasas (Hanks and Hunter, 1995). Mediante este ensayo quinasa, se determinó que, por un lado, VRK1 no fosforila a Plk3 (carril 3), ya que no se detecta señal a la altura de la quinasa Plk3 inactiva (Plk3 ${ }^{\mathrm{K} 52 R}$ ) en presencia de VRK1, y que, sin embargo, la quinasa VRK1 es sustrato de Plk3 (carril 4). Además, se identificó el residuo diana, que resultó ser la serina 342 (carril 5), ya que la señal de fosforilación a la altura de VRK1 desaparece al sustituir la serina en esa posición por una alanina. En la figura 31B se muestra la cuantificación de la fosforilación de VRK1 por Plk3 normalizada respecto al nivel de proteína de VRK1 en el Coomassie de la figura 31A.

A continuación, se realizó un ensayo específico para comprobar que, efectivamente, la quinasa PIk3 no era sustrato de VRK1 (Figura 31C). Se usaron 
varias cantidades del mutante inactivo de Plk3 $\left(\mathrm{Plk}^{\mathrm{K} 52 \mathrm{R}}\right)$, frente a una cantidad constante de VRK1 silvestre. Como control positivo del ensayo se utilizó la proteína p53, que es un sustrato bien establecido de VRK1 (Lopez-Borges and Lazo, 2000; Vega et al., 2004). En ningún caso se detecta fosforilación de Plk3 por VRK1, mientras que se observa claramente cómo VRK1 fosforila a p53 (Figura 31C, primer carril). Los niveles de proteína se comprobaron por inmunoblot (IB) y Ponceau.

A

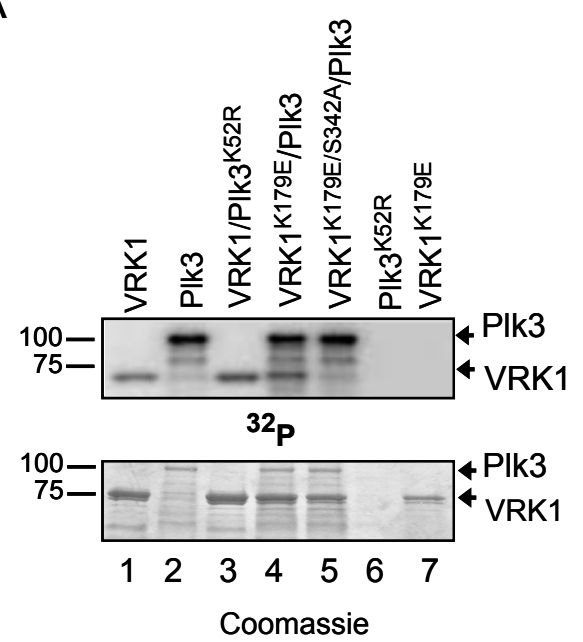

B

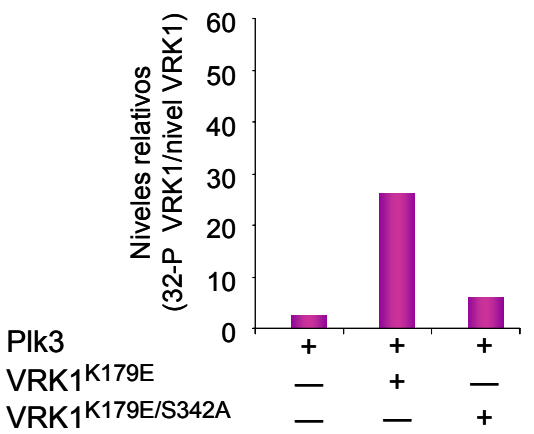

C

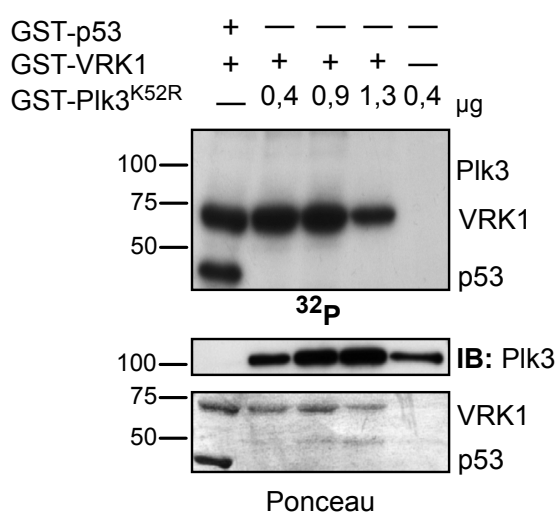

D

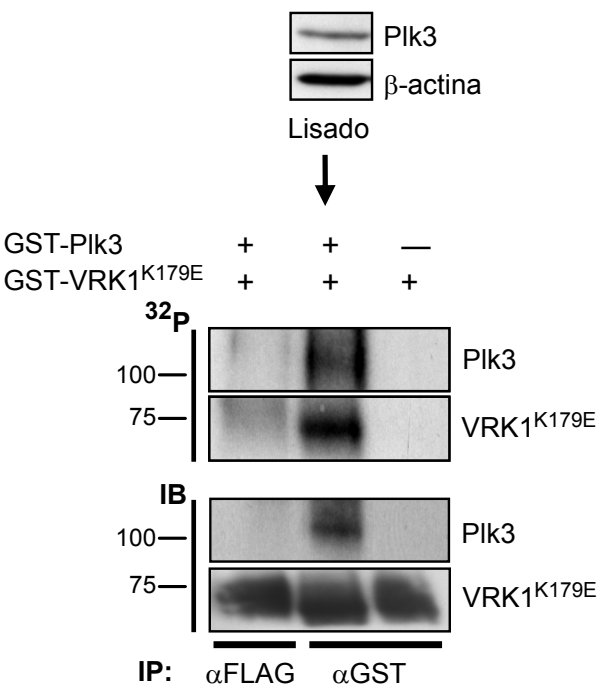

Figura 31. Fosforilación de VRK1 en S342 por Plk3. A) Ensayo quinasa in vitro para determinar el orden de fosforilación entre VRK1 y PIk3. Se utilizaron proteínas de fusión de GST-VRK1, VRK1 sin actividad quinasa (VRK1 ${ }^{\mathrm{K} 179 \mathrm{E}}$ ) o el doble mutante $\mathrm{VRK} 1^{\mathrm{K} 179 \mathrm{I} / \mathrm{S} 342 \mathrm{~A}}$ incapaz de ser fosforilado en serina 342. La proteína GST-PIk3 se usó silvestre o un mutante simple sin actividad quinasa $\left(P I k 3^{\mathrm{K} 52 \mathrm{R}}\right)$. B) Cuantificación de la fosforilación relativa de VRK1. Se realizó para los puntos clave en el apartado A (carriles 2, 4 y 5). C) VRK1 no fosforila a PIk3. Ensayo quinasa in vitro dosis creciente de la proteína de fusión GST-PIk $3^{\mathrm{K} 2 \mathrm{R}}$ y VRK1 silvestre constante. Como control positivo del ensayo se utilizó GST-p53 (aa 1-85). D) Plk3 transfectada e inmunoprecipitada fosforila a VRK1. Se transfectaron células HEK293T con $5 \mu \mathrm{g}$ de pCEFL-GST-PIk3. Se realizó una inmunoprecipitación con un anticuerpo específico para GST y se llevó a cabo un ensayo quinasa in vitro usando como sustrato la proteína de fusión GST-VRK1 ${ }^{\mathrm{K} 179 \mathrm{E}}$. IB- inmunoblot; IPinmunoprecipitación. 
Por último, se realizó un ensayo quinasa utilizando la proteína Plk3 inmunoprecipitada (IP) de células y como sustrato VRK1 ${ }^{\mathrm{K} 179 \mathrm{E}}$ purificada (Figura 31D). Para ello, se transfectó la línea celular HEK293T con una construcción de GST-PIk3. Esta proteína fue inmunoprecipitada con un anticuerpo frente a GST y se utilizó en el ensayo quinasa in vitro. La quinasa GST-PIk3 es activa, como muestra su señal de autofosforilación y es capaz de fosforilar a VRK1 ${ }^{\mathrm{K} 179 \mathrm{E}}$ (Figura 31D, ${ }^{32} \mathrm{P}$ ). Como control del ensayo se realizó una inmunoprecipitación inespecífica con un anticuerpo monoclonal anti-FLAG donde no se detecta fosforilación de VRK1 ${ }^{\mathrm{K} 179 \mathrm{E}}$. Los niveles de proteína se comprobaron por inmunoblot.

Estos resultados indican que VRK1 es fosforilada en la serina 342 por la quinasa Plk3. Este residuo se encuentra en la región carboxilo terminal de VRK1, que se predice como una región flexible y con una posible función reguladora de la quinasa (Lopez-Borges and Lazo, 2000). Por lo tanto, cabe pensar que dicha fosforilación puede inducir un cambio sobre la actividad de la quinasa VRK1.

\subsection{PIk3 no fosforila a otras proteínas VRK.}

El análisis de la secuencia del resto de las proteínas VRK mediante el programa de predicción de posibles motivos funcionales (ELM) identificó sitios de fosforilación para la familia Plk en el resto de las quinasas VRK (Figura 32).

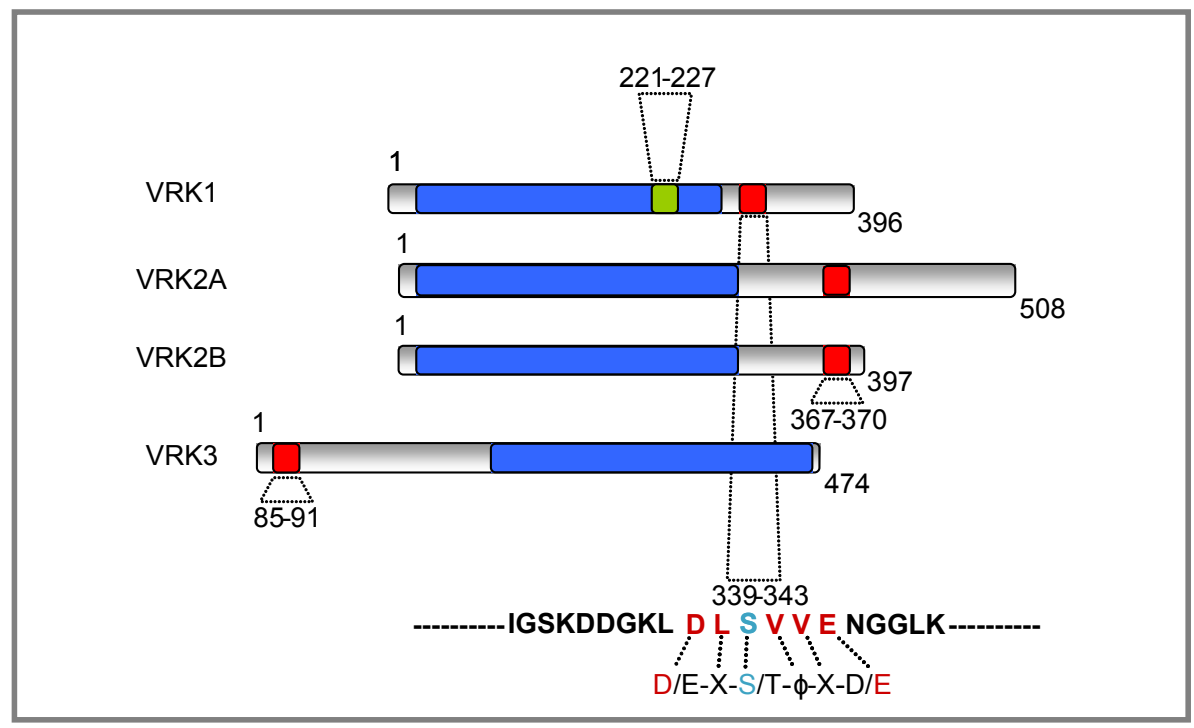

Figura 32. Esquema que muestra los motivos consenso de fosforilación por la familia Plk en las proteínas VRK. Las secuencias de aminoácidos de las proteínas VRK1 (AA19108), VRK2 (AB000450) y VRK3 (BC095449) fueron analizadas mediante el programa ELM. En todas ellas se encontraron motivos consenso para la familia Plk. Se muestran las secuencias consenso fuera del dominio globular (rojo) y también la descrita dentro de él para VRK1 (verde). En azul se representa el dominio quinasa. Además, para VRK1 se especifica la secuencia de aminoácidos con respecto a la secuencia consenso para la familia Plk. X-cualquier aminoácido; $\phi$ - aminoácido hidrofóbico. 
Como se muestra en el esquema, todas las proteínas VRK podrían ser susceptibles de ser sustrato de la familia Plk, ya que tanto las dos isoformas de VRK2 (VRK2A y VRK2B) como la pseudoquinasa VRK3 presentan en su secuencia un posible motivo funcional de fosforilación por las quinasas Plk accesible a estas, ya que se encuentran fuera del dominio globular de cada una de ellas que abarca aproximadamente, lo que es el dominio quinasa (Figura 32, en azul).

Para determinar si alguna otra proteína VRK era sustrato de Plk3, se realizaron ensayos quinasa in vitro en presencia de $\left[\gamma^{3}{ }^{32} \mathrm{P}\right]$ ATP, Plk3 y cada una de las proteínas VRK purificadas (Figura 33).

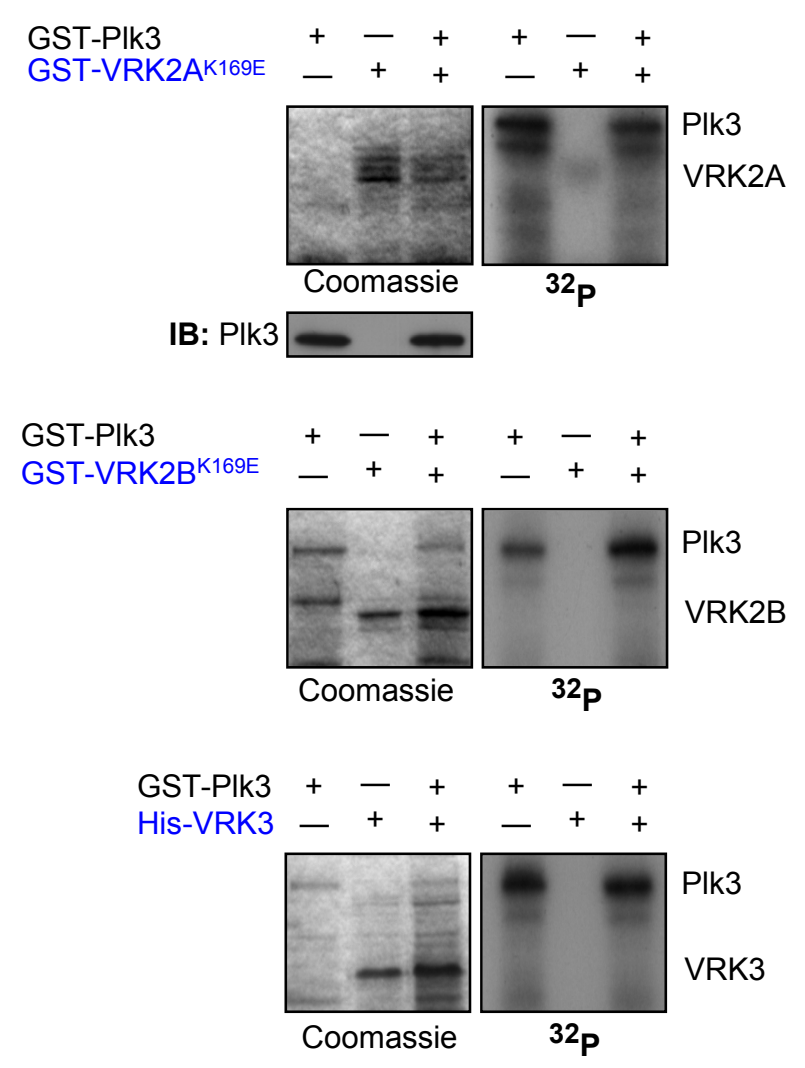

Figura 33. PIk3 no fosforila a VRK2A, VRK2B ni VRK3. Se realizó un ensayo quinasa in vitro utilizando como sustratos de Plk3 las proteínas sin actividad quinasa GST-VRK2A ${ }^{\mathrm{K} 169 \mathrm{E}}$ (panel superior) y GST-VRK2B ${ }^{\mathrm{K} 169 \mathrm{E}}$ (panel intermedio). En el caso de VRK3, al tratarse de una pseudoquinasa, no fue necesaria la utilización de un mutante inactivo (panel inferior). La incorporación de la radiactividad se muestra en las autorradiografías $\left({ }^{32} \mathrm{P}\right)$. Se muestran los niveles de proteína en el Coomassie y/o inmunoblot (IB).

Como se aprecia en los distintos ensayos de la figura 33, en ninguno de los casos se observa incorporación de radiactividad a la altura de las distintas proteínas utilizadas como sustrato: VRK2A ${ }^{\mathrm{K} 169 \mathrm{E}}, \mathrm{VRK}^{\mathrm{B}} \mathrm{B}^{\mathrm{K} 169 \mathrm{E}}$ y VRK3. Tanto de VRK2A como de VRK2B se utilizaron mutantes sin actividad quinasa, ya que, al igual que VRK1, se 
caracterizan por una alta tasa de autofosforilación (Nichols and Traktman, 2004). En el caso de VRK3 no fue necesaria la utilización de un mutante sin actividad quinasa ya que debido a la sustitución de aminoácidos clave en su dominio quinasa es inactiva (Nichols and Traktman, 2004; Scheeff et al., 2009).

De estos ensayos, se puede concluir que Plk3 no es capaz de fosforilar a ningún otro miembro de la familia VRK y que, por lo tanto, la quinasa Plk3 fosforila específicamente a la quinasa VRK1, situándose upstream de ella.

\subsection{La quinasa Plk1 no fosforila a VRK1.}

La quinasa Plk1 también tiene funciones asociadas a una localización subcelular relacionada con el aparato de Golgi (Lin et al., 2000; Sutterlin et al., 2001). Por ello, se quiso descartar que Plk1 fuera también una quinasa upstream de VRK1.

Se llevó a cabo un ensayo quinasa in vitro en presencia de $\left[\gamma^{32}-\mathrm{P}\right]$ ATP, la quinasa Plk1 inmunoprecipitada de células y como sustrato VRK1 ${ }^{\mathrm{K} 179 \mathrm{E}}$ purificada (Figura 34). Para ello, se transfectó la línea celular HEK293T con una construcción constitutivamente activa de Plk1 (Plk1 ${ }^{\top 210 D}$ ), donde su treonina 210 fue sustituida por aspártico, lo que mimetiza la fosforilación de dicho residuo. Para muchas quinasas, la fosforilación directa en el loop de activación provoca su activación (Nolen et al., 2004). En el caso de Plk1, dicho residuo es la treonina 210 (Jang et al., 2002b).

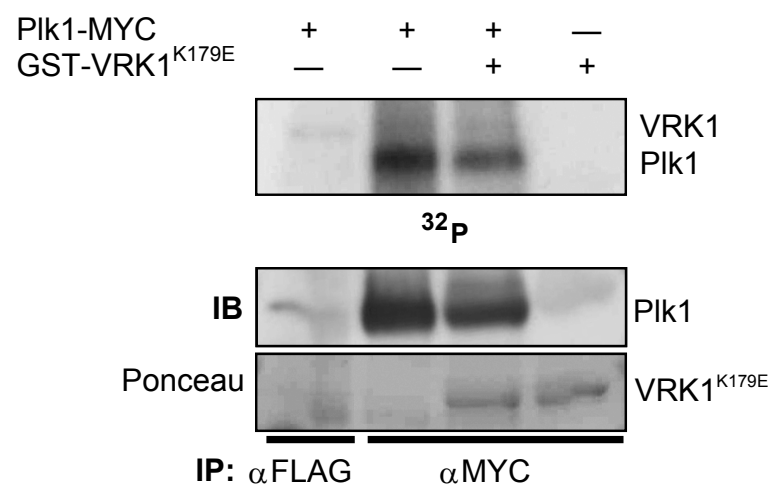

Figura 34. La quinasa PIk1 no fosforila a VRK1. La línea celular HEK293T fue transfectada con $1 \mu \mathrm{g}$ de pRc-CMV-Plk1 ${ }^{\mathrm{T210D}}$. $36 \mathrm{~h}$ después, Plk1 fue inmunoprecipitada con un anticuerpo específico anti-MYC y se realizó un ensayo quinasa in vitro utilizando como sustrato la proteína purificada GST-VRK1 ${ }^{\mathrm{K} 179 \mathrm{E}}$.La proteína PIk1 inmunoprecipitada se detectó por inmunoblot (IB) y la proteína de fusión mediante tinción de Ponceau.

Tras la transfección, se inmunoprecipitó la quinasa Plk1 con un anticuerpo específico frente al epítopo MYC y, como control del ensayo, se hizo en paralelo una 
inmunoprecipitación inespecífica con FLAG (Figura 34, primer carril). Los niveles de proteína se corroboraron por inmunoblot y tinción con Ponceau.

Como se observa en la autorradiografía $\left({ }^{32} \mathrm{P}\right)$, la quinasa Plk1 presenta una fuerte autofosforilación y, sin embargo, no se detecta fosforilación sobre VRK1 ${ }^{\mathrm{K} 179 \mathrm{E}}$.

Teniendo en cuenta todos los ensayos quinasa realizados y los resultados obtenidos, se puede concluir que la quinasa VRK1 es fosforilada únicamente por Plk3, que el residuo diana es la serina 342 y que, además, la quinasa Plk3 no tiene como sustrato a ningún otro miembro de la familia de quinasas VRK.

\subsection{La sobreexpresión de Plk3 provoca un incremento de la actividad de VRK1 endógena.}

Los resultados obtenidos identifican a Plk3 como la primera quinasa descrita upstream de VRK1. Se ha determinado que, en efecto, VRK1 es sustrato de Plk3 in vitro (Figura 31A y D). Por lo tanto, el siguiente paso sería examinar si dicha fosforilación tiene algún efecto sobre la actividad quinasa de VRK1 in vivo.

Para ello, se llevó a cabo un ensayo en el cual se transfectó Plk3 en células HEK293T. A continuación, la proteína VRK1 endógena fue inmunoprecipitada de estas y sometida a un ensayo quinasa para determinar su nivel de actividad (Figura 35).
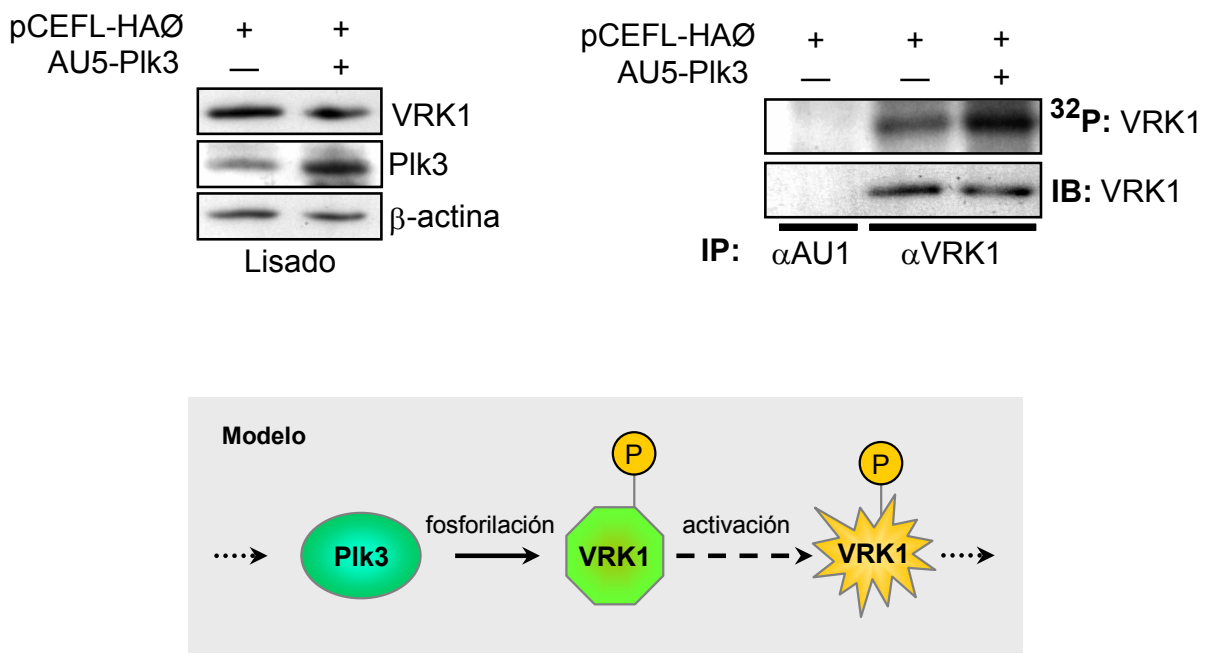

Figura 35. Actividad de VRK1 tras la sobreexpresión de PIk3. La línea celular HEK293T fue transfectada con $5 \mu \mathrm{g}$ de pCEFL-AU5-Plk3 o el vector vacío pCEFL-HA $\varnothing$. Los extractos celulares se analizaron por inmunoblot (panel izquierdo) y los niveles de proteína transfectada (Plk3) o endógena (VRK1) fueron detectados con anticuerpos específicos. Estos extractos fueron usados para inmunoprecipitar la quinasa VRK1 endógena y, a continuación, se llevó a cabo un ensayo quinasa in vitro (panel derecho). Los niveles de proteína inmunoprecipitados se detectaron por inmunoblot. Se muestra un esquema resumen de la relación PIk3-VRK1. 
Tras comprobar que los niveles de proteína de VRK1 no se veían afectados por Plk3 (Figura 35, panel izquierdo), se quiso determinar la actividad quinasa de esa VRK1 endógena. Así, se llevó a cabo una inmunoprecipitación con un anticuerpo específico para VRK1 (VC) y se realizó un ensayo quinasa con ATP radiactivo. Como se aprecia en la figura 35 (panel derecho), tras la sobreexpresión de Plk3, la actividad de VRK1, medida a través de su nivel de autofosforilación, sufre un incremento. Como control de la transfección, se usó un vector vacío (pCEFL-HAØ) y se determinó que la transfección en sí misma no tiene ningún efecto sobre la actividad de la proteína VRK1 endógena. Además, como control de la propia inmunoprecipitación se hizo en paralelo una inespecífica con el anticuerpo AU1.

Este resultado sugiere que la quinasa PIk3 regula positivamente a VRK1 in vivo $y$, dicha regulación, suponemos que sería mediante la fosforilación en la serina 342 de VRK1, como ya ha sido descrito en los apartados anteriores.

\subsection{Colocalización de las quinasas VRK1 y PIk3.}

La localización subcelular de VRK1 es muy variada: se encuentra en el núcleo, excluida o no del nucleolo y en el citoplasma, asociada o no con el aparato de Golgi. Así mismo, la localización subcelular de Plk3 también es muy diversa. Algunos autores la describen en el córtex celular y en el surco de segmentación en citocinesis (Conn et al., 2000). Otros estudios la sitúan en los centrosomas en interfase y en los polos del huso mitótico en mitosis (Dai et al., 2002b; Wang et al., 2002). Además, también se ha descrito en el núcleo, en el nucleolo y en el citoplasma, asociada o no con el aparato de Golgi (Dai et al., 2002b; Wang et al., 2007; Zimmerman and Erikson, 2007b).

Para comprobar si existía colocalización de las proteínas VRK1 y Plk3, se analizó la localización subcelular de ambas. Para ello, se realizaron dobles tinciones utilizando las líneas celulares HEK293T y A549, dos anticuerpos distintos para VRK1 (VE1 y 1F6) que identifican dos subpoblaciones citoplasmáticas diferentes $y$, en ambos casos, la quinasa Plk3 transfectada (Figura 36).

La línea celular HEK293T se transfectó con HA-PIk3 (Figura 36A), detectándose Plk3 con un anticuerpo monoclonal para el epítopo HA (rojo), mientras que VRK1 se identificó con un anticuerpo policlonal (VE1-verde). Por otro lado, la línea celular A549 (Figura 36B) se transfectó con FLAG-Plk3, detectándose esta con un anticuerpo policlonal para el epítopo FLAG (rojo), mientras que para la proteína VRK1 endógena se utilizó el anticuerpo monoclonal 1F6 (verde), que identifica principalmente la subpoblación asociada al aparato de Golgi. 
Tanto en HEK293T como en A549 se observa cierto grado de colocalización. En el caso de la línea celular HEK293T, VRK1 se observa en el núcleo y en el citoplasma en forma de gránulos y es ahí donde solapa la señal de ambas quinasas. En la línea celular A549, el patrón es distinto. VRK1 se detecta homogénea en el núcleo y en un agregado perinuclear (aparato de Golgi) en el citoplasma. Aquí también colocalizan ambas quinasas en los gránulos citoplasmáticos. Estos datos sugieren que, al menos una subpoblación de ambas proteínas, puede estar formando un complejo intracelular particulado.

En la tabla se muestra la cuantificación del grado de colocalización para ambas proteínas en las dos líneas celulares. Dados los valores obtenidos, se puede concluir que la correlación que existe en la distribución de ambas quinasas no es aleatoria.

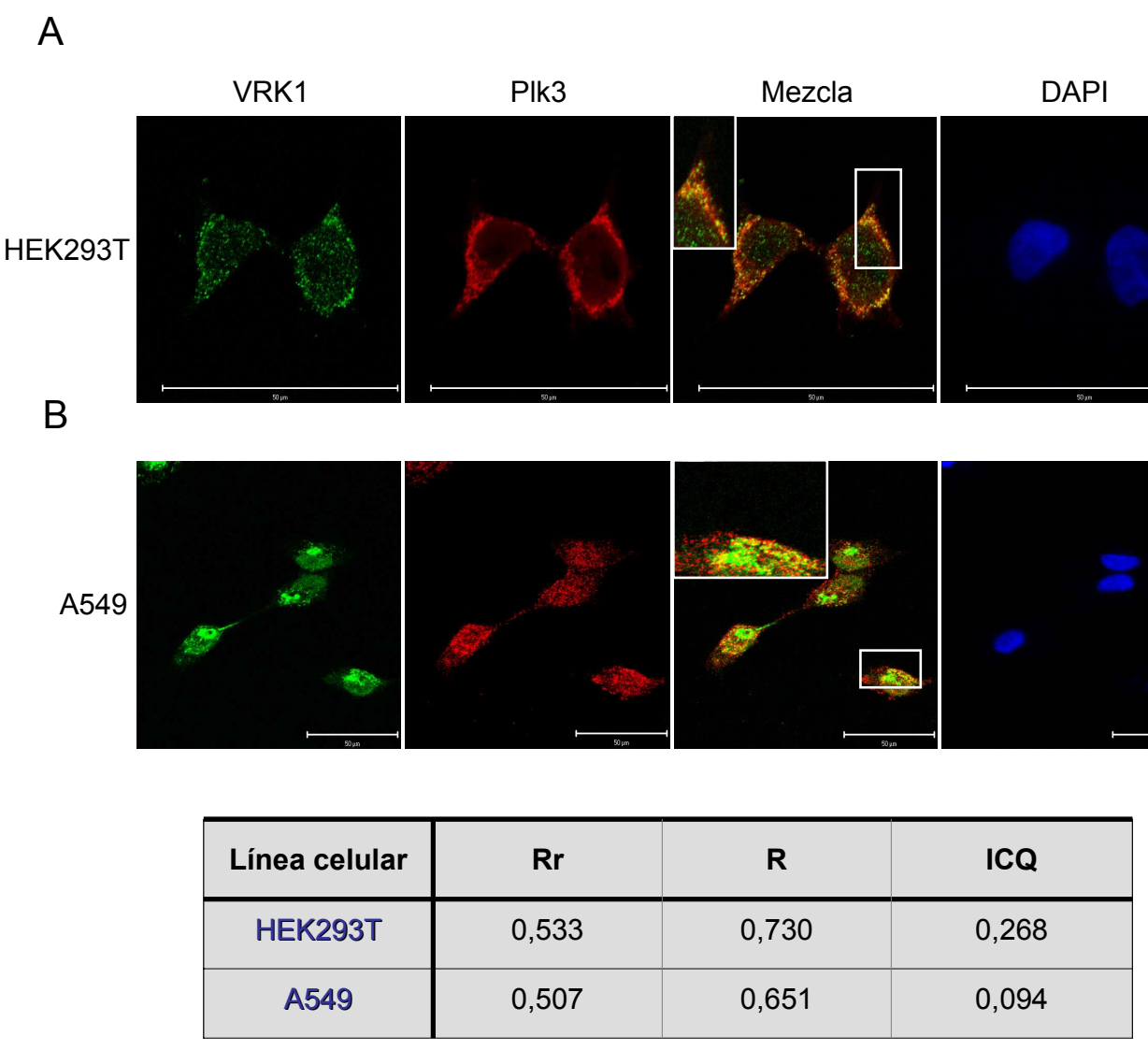

Figura 36. Colocalización de VRK1 endógena y Plk3 sobreexpresada. A) Colocalización específica de HA-PIk3 (3 $\mu \mathrm{g})$ expresada exógenamente en HEK293T, detectada con un anticuerpo monoclonal anti-HA (rojo) y la proteína VRK1 endógena detectada con un anticuerpo policlonal (verde). B) Colocalización específica de FLAG-PIk3 (3 $\mu \mathrm{g})$ expresada exógenamente en A549, detectada con un anticuerpo policlonal anti-FLAG (rojo) y la proteína VRK1 endógena detectada con un anticuerpo monoclonal (verde). El ADN se tiñó con DAPI (azul). La barra indica $50 \mu \mathrm{m}$. Se muestra una tabla con los datos cuantitativos de la colocalización. Rr-coeficiente de correlación de Pearson; R- coeficiente de Mander; ICQ- grado de correlación de la intensidad. 


\subsection{Análisis de la interacción VRK1-PIk3.}

\subsubsection{VRK1 no forma complejos proteicos de alto peso molecular.}

Los resultados obtenidos por proteómica (Figura 30) apuntaban la posibilidad de que VRK1 y Plk3 pudieran interaccionar. Por otro lado, tratando de profundizar en las características específicas de la quinasa VRK1 y considerando que en otros estudios del laboratorio se había identificado VRK2 como parte de complejos de alto peso molecular (Blanco et al., 2007; Blanco et al., 2008), se quiso analizar si VRK1, bajo las mismas condiciones experimentales que VRK2, también formaba parte de complejos proteicos de medio y alto peso molecular. Para ello, se realizó una cromatografía de exclusión por tamaño, utilizando células HEK293T y analizando la distribución de la proteína VRK1 endógena. Además, también se comprobó la distribución de Plk3 (Figura 37).

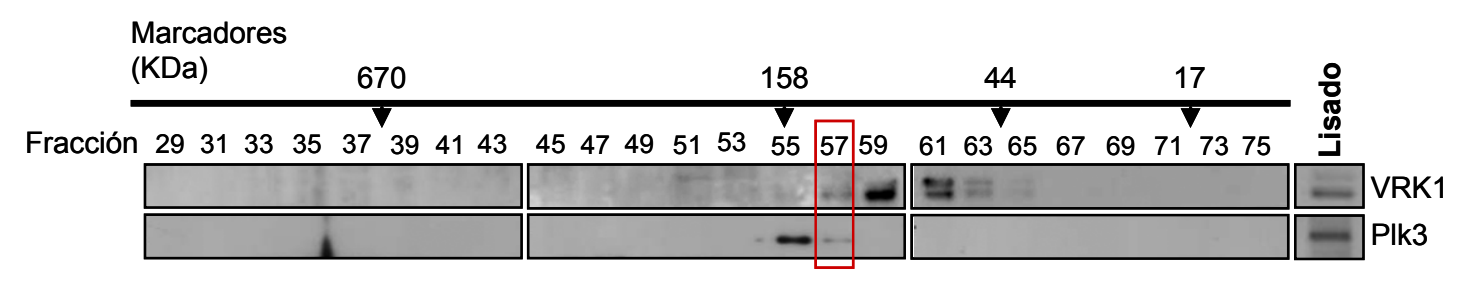

Figura 37. La quinasa VRK1 aparece en fracciones de medio-bajo peso molecular. Se utilizaron $3 \mathrm{mg}$ de extracto de células HEK293T. Este extracto fue sometido a un ensayo de cromatografía de exclusión por tamaño, en el que se recogieron fracciones de $200 \mu$ l. Las proteínas se detectaron mediante inmunoblot con anticuerpos específicos para VRK1 y Plk3. Se muestra el lisado total (panel derecho).

En el ensayo se recogieron fracciones de $200 \mu \mathrm{l}$ y las proteínas presentes en ellas se precipitaron mediante tricloroacético. A continuación, se cargaron las fracciones impares en geles SDS-PAGE del $10 \%$ al acrilamida. Como se muestra en la figura 37, se utilizó una mezcla de marcadores de peso molecular de 17-670 KDa, aunque las fracciones muestran un rango más amplio.

La quinasa VRK1 tiene un peso molecular de $49 \mathrm{KDa}$. Por lo tanto, las fracciones de bajo peso molecular (fracciones 61, 63 y 65) en las que se observa corresponderían a monómeros de VRK1 y/o a complejos de VRK1 con proteínas de muy bajo peso molecular. Además, también se detecta en fracciones intermedias (fracciones 57 y 59) en torno a 100-120 KDa, que podrían corresponder a dímeros. Por su parte, la quinasa Plk3, bajo estas condiciones, solamente se detecta en fracciones intermedias (fracciones 53,55 y 57 ), pese a haberse descrito en algunos estudios en 
fracciones de hasta $600 \mathrm{KDa}$ (Bahassi el et al., 2002; Bahassi el et al., 2004). El peso molecular de Plk3 son $70 \mathrm{KDa}$, por tanto, parece que la proteína Plk3 que se está detectando en estas fracciones no es en forma de monómero. Tanto VRK1 como Plk3, eluyen juntas en la fracción 57, lo que podría estar indicando que forman un heterodímero de unos $120 \mathrm{KDa}$.

A diferencia de lo descrito para VRK2 (Blanco et al., 2007; Blanco et al., 2008), la quinasa VRK1 no forma complejos de alto peso molecular, ya que en las fracciones correspondientes (fracciones 29-43) no se detecta señal de VRK1.

\subsubsection{Interacción de las proteínas VRK1 y Plk3 in vivo.}

Una vez que se determinó que, efectivamente, hay una subpoblación de ambas quinasas colocalizando en el citoplasma (Figura 36) y que eluyen juntas (Figura 37), se quiso comprobar si las proteínas endógenas interaccionaban in vivo. Lo primero fue analizar los niveles de expresión de ambas proteínas en un panel de líneas celulares (Figura 38A). Para ello, se utilizaron cultivos asincrónicos y anticuerpos específicos para VRK1 y Plk3. Se determinó que en H1299, A549, HEK293T, MCF-7 y WS1 (fibroblasto normal de piel) los niveles de expresión son semejantes para ambas proteínas. Sin embargo, en U-2OS (osteosarcoma) es mayor el nivel de expresión de Plk3, mientras que en las líneas celulares HeLa, Jurkat (leucemia linfoide T aguda) y Cos1 (fibroblasto de riñón de mono verde) es la quinasa VRK1 la que se expresa en mayor medida.

Para confirmar la interacción de ambas quinasas se realizó un ensayo de coinmunoprecipitación de las proteínas endógenas utilizando extracto de células HEK293T. La proteína VRK1 se inmunoprecipitó con un anticuerpo monoclonal (1F6) y la proteína Plk3 precipitada fue detectada por inmunoblot con un anticuerpo específico policlonal (Figura 38B). Como control se realizó una inmunoprecipitación con un anticuerpo inespecífico del mismo isotipo sin ninguna diana endógena ( $\alpha-F L A G)$. Como se aprecia en la figura 38B, Plk3 se detectó en el precipitado de VRK1 pero no en el control con el anticuerpo anti-FLAG. La proporción de Plk3 que interacciona con VRK1 es aproximadamente un 4\%, lo que implica que la interacción tiene lugar entre subpoblaciones de ambas quinasas. No se pudo realizar una inmunoprecipitación recíproca porque los anticuerpos para Plk3 no funcionan en esta técnica.

Para demostrar firmemente la interacción entre VRK1 y Plk3 se realizaron dos aproximaciones más. En primer lugar, teniendo en consideración los problemas técnicos para inmunoprecipitar la quinasa Plk3 endógena, se realizaron 
inmunoprecipitaciones recíprocas utilizando proteínas transfectadas en células HEK293T (Figura 39A). De este modo, se transfectaron los vectores pCEFL-HA-VRK1, pCEFL-FLAG-PIk3 o ambos. Una vez comprobados los niveles de expresión de las proteínas, se llevaron a cabo inmunoprecipitaciones recíprocas usando para precipitar VRK1 un anticuerpo monoclonal anti-HA (Figura 39A, panel izquierdo) y, para precipitar Plk3, un anticuerpo policlonal anti-FLAG (Figura 39A, panel derecho). Las proteínas asociadas al precipitado se detectaron, en cada caso, con el anticuerpo recíproco. En los dos ensayos se observó la interacción VRK1-PIk3.

A

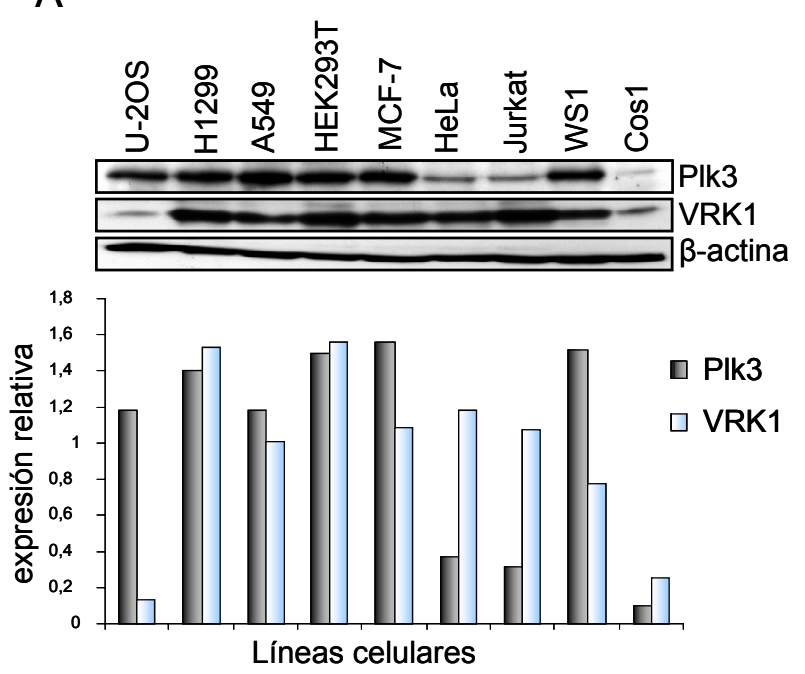

B

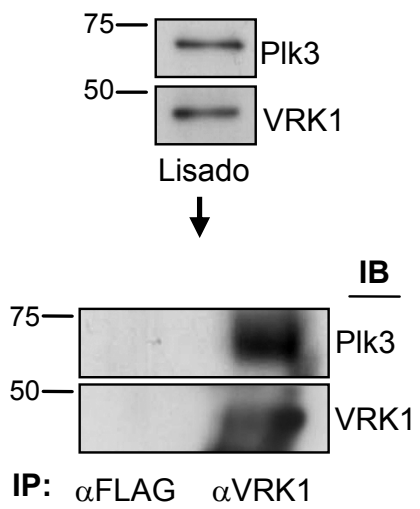

Figura 38. Interacción de VRK1 y Plk3. A) Expresión de VRK1 y Plk3 en líneas distintas celulares. Detección de VRK1 y Plk3 endógenas con anticuerpos específicos en diferentes líneas celulares. Se muestra una gráfica de la expresión relativa normalizada respecto a $\beta$-actina. B) Interacción de VRK1 y PIk3 endógenas. En la parte superior se muestran los extractos celulares totales de células HEK293T. Estos extractos $(2 \mathrm{mg}$ ) fueron usados para inmunoprecipitar VRK1 con un anticuerpo monoclonal específico (1F6) y se detectó la presencia de Plk3 con un anticuerpo policlonal. Como control del ensayo se realizó una inmunoprecipitación inespecífica con un anticuerpo anti-FLAG monoclonal. IP- inmunoprecipitación; IB- inmunoblot.

En segundo lugar, se utilizaron construcciones de VRK1 y Plk3 silvestres y mutantes sin actividad quinasa fusionadas a GST para llevar a cabo ensayos de precipitación con la resina Glutathion Sepharose (PD-pulldown) (Figura 39B). Para ello, se transfectaron los vectores pCEFL-GST-PIk3, pCEFL-GST-PIk3 ${ }^{\mathrm{K} 52 \mathrm{R}}$ y pCEFLGSTØ. Estos extractos se incubaron con $20 \mu \mathrm{l}$ de la resina y, tras los lavados correspondientes, se realizó un inmunoblot para detectar la proteína VRK1 endógena asociada (Figura 39B, panel izquierdo en azul). La proteína endógena VRK1 interacciona tanto con Plk3 silvestre como con la quinasa inactiva pero no con el control de pCEFL-GSTØ. Sin embargo, la interacción es más estable en presencia de 
su quinasa upstream sin actividad quinasa $\left(P l k 3^{K 52 R}\right)$. En el ensayo recíproco, se transfectaron los vectores pCEFL-GST-VRK1, pCEFL-GST-VRK1 $1^{\mathrm{K} 179 \mathrm{E}}$ y pCEFLGSTØ. En este pulldown, se analizó si la proteína Plk3 endógena también precipitaba asociada a VRK1 (Figura 39B, panel derecho en azul). En este caso, la quinasa Plk3 interacciona establemente tanto con VRK1 silvestre como con la quinasa inactiva, pero no con el control (pCEFL-GSTØ).

A

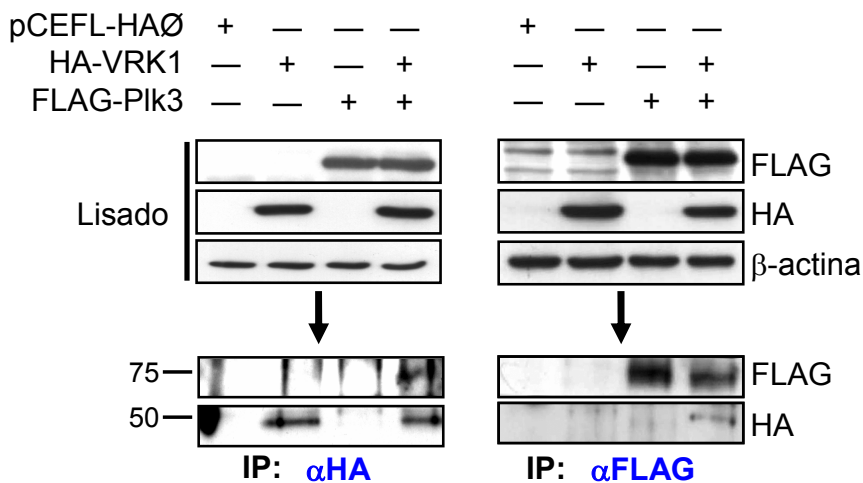

B
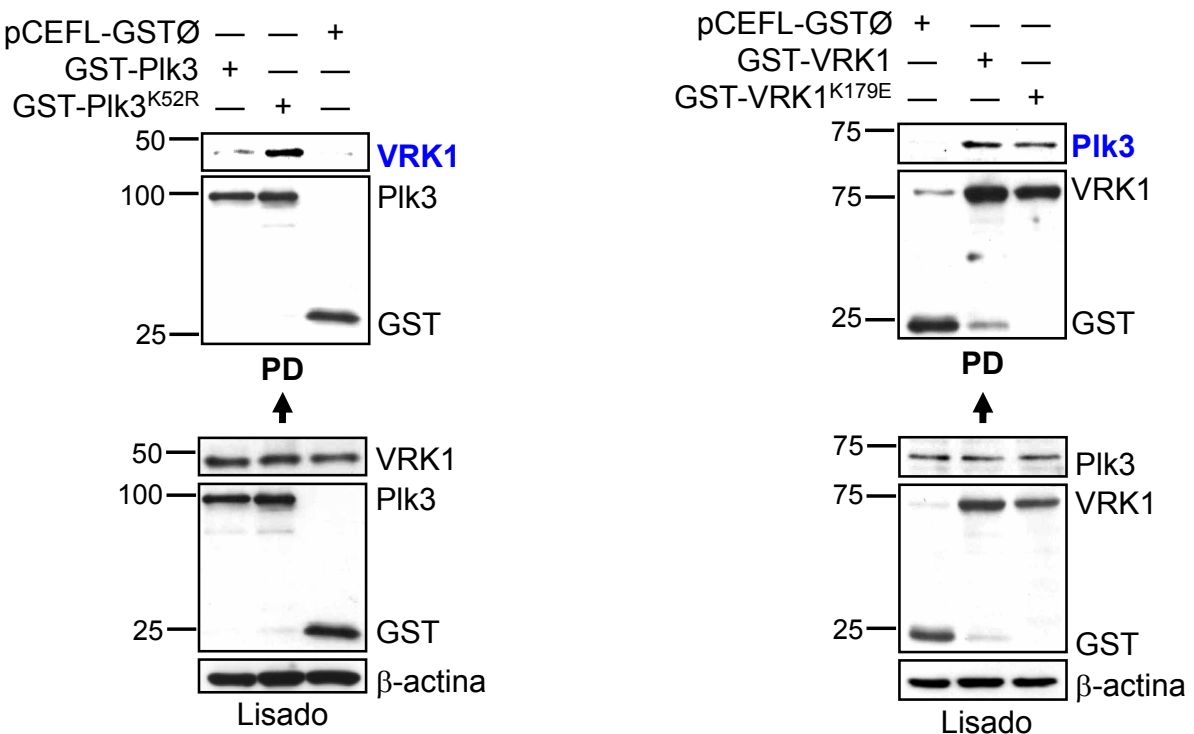

Figura 39. A) Ensayos de inmunoprecipitación para determinar la interacción VRK1-PIk3. Se transfectaron células HEK293T con vector vacío pCEFL-HAØ, pCEFL-HA-VRK1 (5 $\mu \mathrm{g})$, pCEFLFLAG-PIk3 $(5 \mu \mathrm{g})$ y ambas. En la parte superior se muestra el inmunoblot de los extractos celulares totales. Estos extractos $(1 \mathrm{mg}$ ) fueron usados para inmunoprecipitaciones recíprocas y en ambos casos se detectó por inmunoblot la otra proteína. Las inmunoprecipitaciones fueron realizadas con anticuerpos comerciales específicos para los epítopos HA y FLAG. B) Ensayos de pulldown (PD). Se realizaron ensayos de pulldown recíprocos. En el panel izquierdo, se transfectaron pCEFL-GST-PIk3 $(6 \mu \mathrm{g})$, pCELF-GST-PIk3 ${ }^{\mathrm{K} 52 \mathrm{R}}(6 \mu \mathrm{g})$ o vector vacío $(2 \mu \mathrm{g})$ y se detectó VRK1 endógena con el anticuerpo 1F6. En el panel derecho, se transfectaron pCEFLGST-VRK1 $(4 \mu \mathrm{g})$, pCEFL-GST-VRK1 ${ }^{\mathrm{K} 179 \mathrm{E}}(8 \mu \mathrm{g})$ o vector vacío $(2 \mu \mathrm{g})$ y se detectó Plk3 endógena con un anticuerpo monoclonal específico. 
De toda esta serie de ensayos de interacción, se puede concluir que, a pesar de que los datos iniciales no estimaban una interacción significativa, parece que ambas quinasas forman un complejo relativamente estable in vivo y este se detecta mediante coinmunoprecipitaciones y pulldowns de proteínas endógenas y/o transfectadas.

\subsubsection{Determinación de la zona de interacción de VRK1 con PIk3.}

Una vez confirmada la interacción VRK1-Plk3 in vivo, se continuó con la identificación de la región implicada en dicha interacción.

A

B

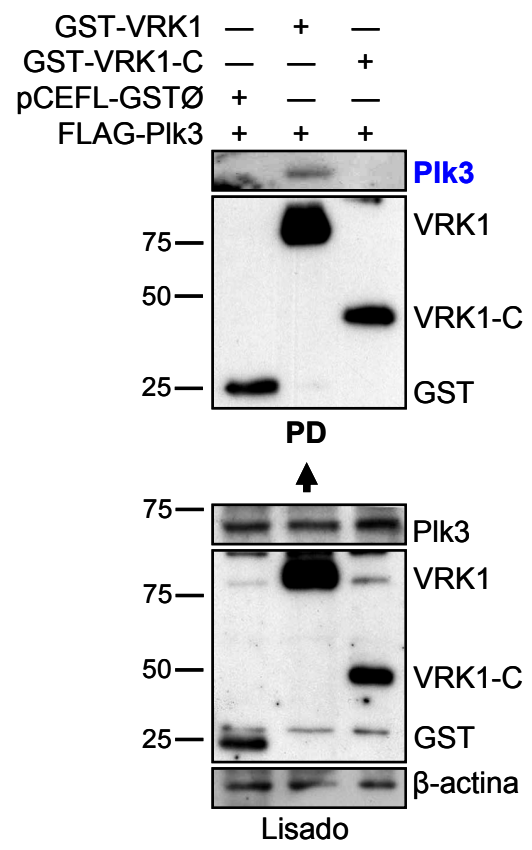

$\begin{array}{rcccc}\text { GST-PIk3 } & - & + & + & + \\ \text { pCEFL-GST } & + & - & - & - \\ \text { VRK1 } & + & + & - & - \\ \text { VRK1-NL } & - & - & + & - \\ \text { VRK1-Nc } & - & - & - & +\end{array}$

C
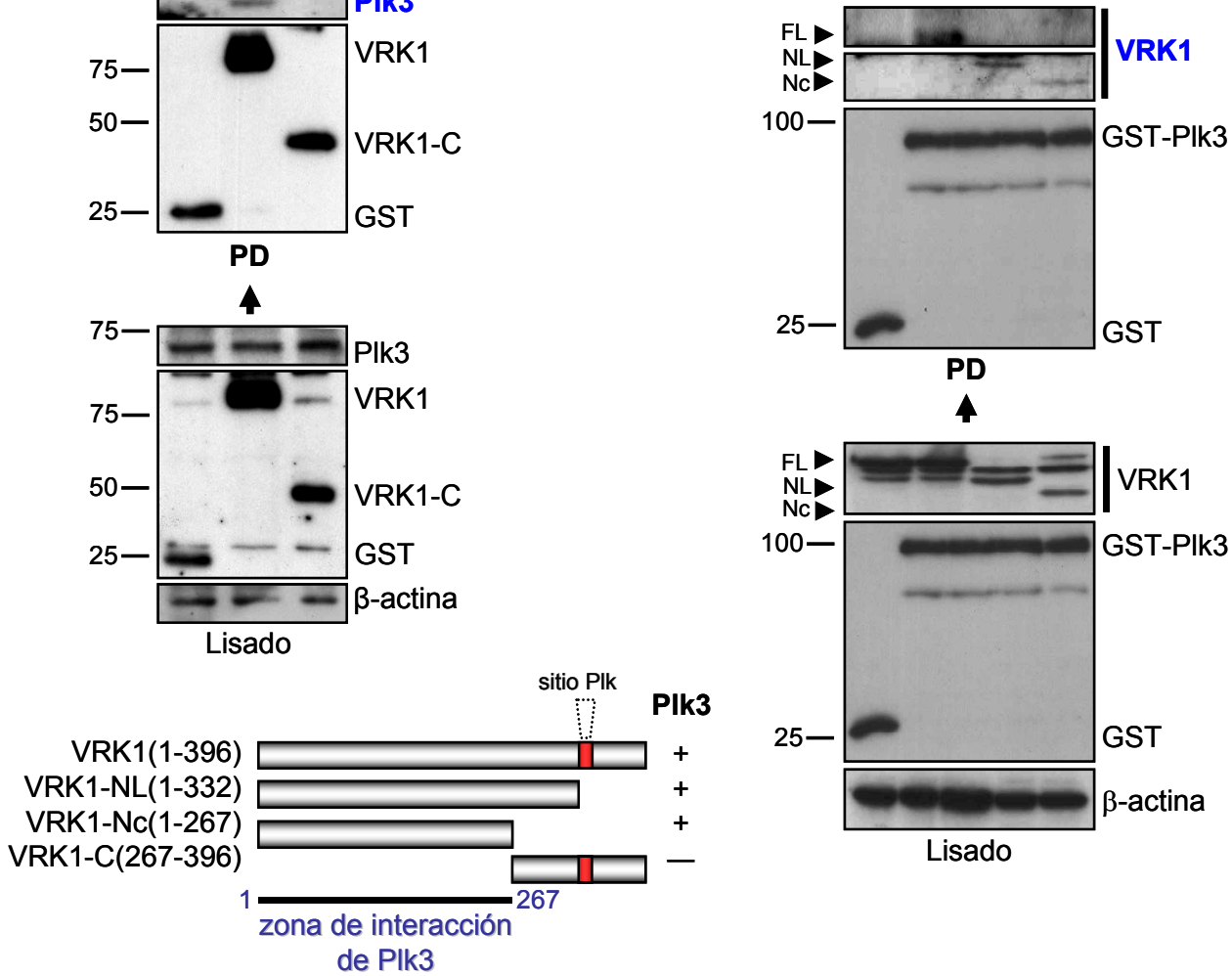

4

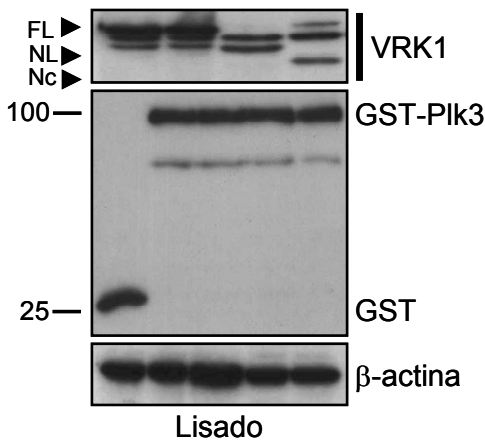

Figura 40. PIk3 interacciona por la región $\mathbf{N}$-terminal de VRK1. A) Se transfectaron células HEK293T con pCEFL-FLAG-PIk3 (3 $\mu \mathrm{g})$, pCEFL-GST-VRK1 $(4 \mu \mathrm{g})$, pCEFL-GST-VRK1-C $(6 \mu \mathrm{g})$ y vector vacío pCEFL-GST $\varnothing(2 \mu \mathrm{g})$. Se realizó un ensayo de pulldown con la resina Glutathion Sepharose y las proteínas se detectaron con anticuerpos específicos anti-FLAG y anti-GST. B) Las células HEK293T fueron transfectadas con pCDNA-VRK1-MYC $(5 \mu \mathrm{g})$, pCDNA-VRK1-(NL)-MYC (5 $\mu \mathrm{g})$, pCDNA-VRK1-(Nc)-MYC $(9 \mu \mathrm{g})$, pCEFL-GST-PIk3 $(6 \mu \mathrm{g})$ y vector vacío pCEFL-GST $\varnothing(2 \mu \mathrm{g})$. Se precipitaron las proteínas y se analizaron por inmunoblot con anticuerpos específicos para VRK1 (VE1) y para GST. C) Esquema de las distintas construcciones de VRK1 usadas y la zona de interacción con Plk3. 
Se realizaron ensayos de pulldown utilizando plásmidos de VRK1 que codifican distintas regiones de la proteína: VRK1 completa (GST-VRK1, aa 1-396), VRK1 carboxilo (GST-VRK1-C, que comprende la región carboxilo terminal, aa 267-396), VRK1 amino corta (VRK1-Nc, que comprende la región amino terminal, aa 1-267) y VRK1 amino larga (VRK1-NL, que comprende una región amino terminal más larga, aa 1-322) (Figura 40C).

En un primer ensayo, se utilizaron las construcciones de VRK1 completa y VRK1 carboxilo fusionadas a GST para precipitar la proteína Plk3 transfectada (Figura 40A). Tras la incubación de los extractos con la resina Glutathion Sepharose, se analizó el precipitado para detectar la presencia de Plk3 con un anticuerpo frente al epítopo FLAG (Figura 40A, panel superior en azul). Se comprobó que la quinasa Plk3 solamente se precipitaba con la construcción de la proteína VRK1 completa.

A continuación, se realizó un ensayo de pulldown utilizando, en este caso, Plk3 fusionada a GST y las construcciones de VRK1 completa, amino larga y amino corta (Figura 40B). Tras la precipitación de las proteínas asociadas a Plk3, se determinó qué construcciones de VRK1 interaccionaban con Plk3 (Figura 40B, panel superior en azul). En todos los casos, se observó la presencia de VRK1, lo que indica que la zona común a las construcciones de la proteína VRK1 completa, VRK1 amino corta y VRK1 amino larga, pero ausente en la construcción de VRK1 carboxilo, es la zona implicada en la interacción con Plk3. Es decir, la región que interacciona con Plk3 es aquella comprendida entre los aminoácidos 1-267 (Figura 40C).

\subsection{Implicación de VRK1 en la fragmentación del aparato de Golgi en división celular.}

La quinasa VRK1 ha sido desde el principio relacionada con proliferación y división celular debido a sus altos niveles de expresión tanto en tejidos proliferativos como en líneas celulares tumorales y normales (Nezu et al., 1997; Santos et al., 2006). De hecho, su expresión correlaciona positivamente con marcadores de proliferación (Santos et al., 2006; Valbuena et al., 2007b). Más recientemente, se le han asignado funciones específicas en distintas fases del ciclo celular. Así, por ejemplo, en mitosis participa en la condensación de la cromatina mediante la fosforilación de la histona H3 y en la dinámica de la envuelta nuclear mediante la fosforilación de la proteína BAF (Nichols et al., 2006; Kang et al., 2007). Teniendo en cuenta la relación establecida entre las quinasas PIk3 y VRK1 y considerando, por un lado, las funciones descritas para Plk3 y, por otro, la localización subcelular de ambas, se pensó en la hipótesis de 
que VRK1 fuera la quinasa situada por debajo de Plk3 en la ruta de la fragmentación del aparato de Golgi en mitosis en la que se había implicado a la quinasa Plk3 por debajo de MEK1 (Xie et al., 2004). De este modo, se decidió analizar esta nueva posible función de VRK1 en mitosis y, para ello, lo primero que se hizo fue determinar el nivel de activación de VRK1 en mitosis bajo nuestras condiciones experimentales.

\subsubsection{Nivel de activación de VRK1 en mitosis.}

No existen demasiados datos sobre el nivel de actividad de la quinasa VRK1 a lo largo del ciclo celular, aunque en un estudio realizado por Kang se apuntaba a un aumento de la actividad de VRK1 en la fase G2/M del ciclo celular medido a través del grado de fosforilación de su sustrato histona H3 (Kang et al., 2007). En este estudio, además, se propone que el nivel de proteína de VRK1 varía en las distintas fases del ciclo celular, e incluso se muestra que VRK1 es prácticamente indetectable a partir de anafase observado mediante inmunofluorescencia (Kang et al., 2007). Dada la discrepancia con los resultados aquí mostrados, al menos respecto a los niveles de proteína a lo largo de las distintas fases de la mitosis detectados mediante inmunofluorescencia (Figuras 27 y 28), y teniendo en cuenta lo relevante de esta posible activación de la quinasa VRK1 en mitosis, se decidió confirmar si, en efecto, VRK1 se activaba en esa fase del ciclo celular. Para ello, se inmunoprecipitó la proteína VRK1 endógena con un anticuerpo policlonal específico (VC) a partir de células HeLa no sincronizadas, de células HeLa bloqueadas en G2/M con nocodazol y de células HeLa liberadas del bloqueo en dos tiempos distintos. La parada del ciclo celular de las células HeLa se comprobó mediante citometría de flujo y, como se puede observar en la figura 41A, la eficiencia de la parada en fase G2/M por nocodazol a una concentración de $83 \mathrm{nM}$ durante $15 \mathrm{~h}$ es buena, alcanzando prácticamente un 95\% de células en fase G2/M. Una vez comprobada la parada y liberación de las células, se determinó el nivel de proteína de VRK1 por inmunoblot en cada circunstancia. Como se puede ver en la figura 41B (panel superior), la cantidad de VRK1 es constante en cada uno de los puntos que incluyen, células asincrónicas, células en mitosis y células en fase G1 (a las dos horas de la liberación hay un $73 \%$ de células HeLa en fase G1). Además, como se puede observar en la autorradiografía (Figura 41B, panel inferior), la actividad de VRK1 medida a través de su autofosforilación y la fosforilación de su sustrato histona $\mathrm{H} 3$ es máxima en mitosis. Como control del ensayo, se realizó una inmunoprecipitación inespecífica con un anticuerpo anti-HA. La cantidad de VRK1 
inmunoprecipitada se detectó por inmunoblot con una anticuerpo monoclonal (1F6) y el nivel de histona $\mathrm{H} 3$ recombinante por tinción con Ponceau.
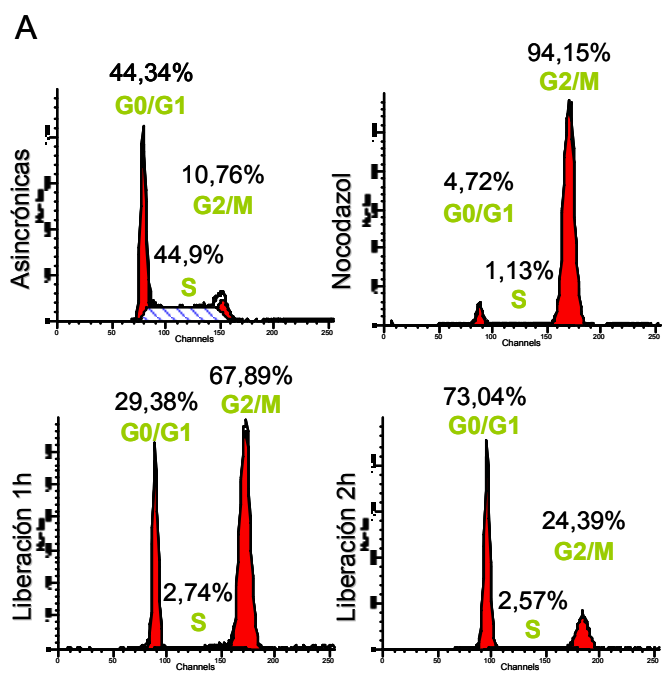

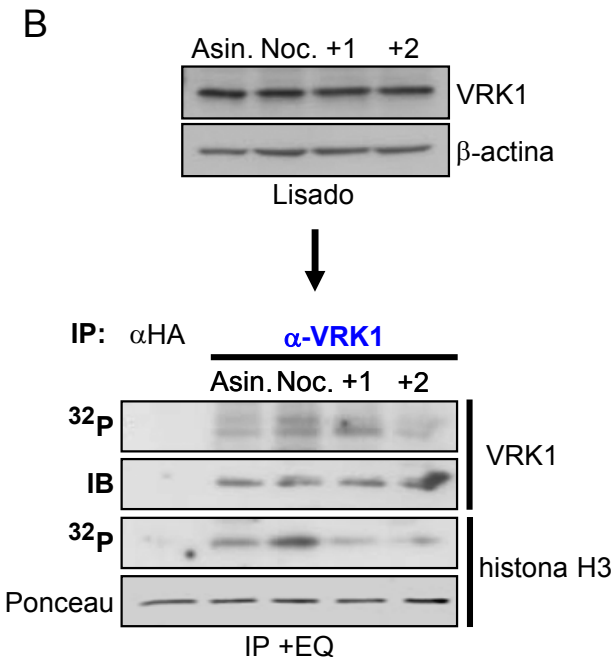

Figura 41. VRK1 es más activa en mitosis. A) Perfil de ciclo de células HeLa asincrónicas, en mitosis (nocodazol $83 \mathrm{nM}, 15 \mathrm{~h}$ ) y liberadas a $1 \mathrm{~h}$ y $2 \mathrm{~h}$. B) Inmunoblot de células tratadas como en el apartado A. Se detectó el nivel de proteína de VRK1 con un anticuerpo policlonal (VC) (panel superior). Estos extractos se utilizaron para inmunoprecipitar VRK1 endógena (VC) y realizar un ensayo quinasa in vitro (IP+EQ). Se muestra la autofosforilación de VRK1 y la fosforilación de histona H3 $\left({ }^{32} \mathrm{P}\right)$. La cantidad de VRK1 inmunoprecipitada se detectó por inmunoblot y la cantidad de proteína histona H3 mediante tinción con Ponceau. Asin.- asincrónicas; Noc.- nocodazol; +1,+21 hora y 2 horas tras la liberación del tratamiento con nocodazol.

De este ensayo se puede concluir que, efectivamente, la quinasa VRK1 se activa en mitosis y que esta activación decae tras entrar en la fase G1 del ciclo celular. Sin embargo, a diferencia de lo descrito por Kang (Kang et al., 2007), no se detectan variaciones en los niveles de proteína de VRK1 ni por inmunoblot ni por inmunofluorescencia (ver figuras 27 y 28 ).

\subsubsection{Correlación de los niveles de activación de MEK1, PIk3 y} VRK1 en mitosis.

Aparte de las funciones descritas para la ruta de las MAP quinasas en el ciclo celular dependientes de la activación por señales mitogénicas, estas quinasas también se activan específicamente en mitosis y este es el caso, por ejemplo, de MEK1 (Shapiro et al., 1998; Laird et al., 1999; Chang and Karin, 2001; Colanzi et al., 2003b). De hecho, la quinasa MEK1 tiene funciones clave en la transición G2/M del ciclo celular (Shapiro et al., 1998; Wright et al., 1999; Feinstein and Linstedt, 2007) y el tratamiento con inhibidores específicos de esta lleva a un retraso de la entrada en mitosis (Wright 
et al., 1999; Roberts et al., 2002). Por su parte, algunos datos determinan que la quinasa Plk3 también se activa en la transición G2/M del ciclo celular y, además, se ha demostrado que MEK1 y Plk3 forman parte de una misma ruta de señalización que funciona en mitosis (Chase et al., 1998; Bahassi el et al., 2002; Xie et al., 2004). Puesto que existe una correlación positiva en el grado de activación de MEK1 y Plk3 en mitosis y, como se ha demostrado en este trabajo, VRK1 se sitúa por debajo de Plk3 (Figura 31), se decidió analizar si, en efecto, correlacionaban los niveles de activación de MEK1 y Plk3 con los de VRK1 en mitosis.

El nivel de activación de la proteína Plk3 endógena no se pudo medir en paralelo al de la quinasa VRK1 debido a que los anticuerpos para Plk3 no funcionan en inmunoprecipitación y no hay anticuerpos fosfoespecíficos. Por eso, se decidió analizar el nivel de activación sobre la quinasa Plk3 transfectada.

Para determinar el grado de activación de la quinasa VRK1 respecto al de MEK1, se utilizaron células HeLa de cultivos asincrónicos frente a células HeLa en mitosis, resultado del tratamiento con nocodazol como en experimentos anteriores (Figura 41). Tras comprobar mediante citometría de flujo el perfil de ciclo de las células HeLa que se iban a utilizar en el ensayo (Figura 42A) y corroborar que, en efecto, se habían parado en mitosis, se procedió a analizar el nivel de activación de MEK1 con un anticuerpo fosfoespecífico (Figura 42B, panel superior). Como se observa en el inmunoblot del lisado celular, el nivel de activación de MEK1, medido por su grado de fosforilación en residuos específicos (Ser217/221), es mayor en células en mitosis que en células asincrónicas. A continuación, estos extractos se utilizaron para inmunoprecipitar la quinasa VRK1 endógena con un anticuerpo monoclonal (1F6) y llevar a cabo un ensayo quinasa in vitro en presencia de $\left[{ }^{32} \gamma-P\right]$ ATP (IP+EQ) (Figura 42B, panel inferior). Como se aprecia en la autorradiografía $\left({ }^{32} \mathrm{P}\right)$, la actividad de VRK1 endógena, medida a través de su autofosforilación, es mayor en células en mitosis respecto al de células asincrónicas. La cantidad de VRK1 inmunoprecipitada se comprobó por inmunoblot con un anticuerpo policlonal (VC). Como control de la inmunoprecipitación se hizo una en paralelo con un anticuerpo anti-HA monoclonal.

Por último, se comprobó el nivel de actividad de la quinasa Plk3 transfectada (pCEFL-GST-PIk3) en células HeLa, tratadas o no con nocodazol para pararlas en mitosis. Tras determinar que los niveles de proteína eran correctos (Figura 42C, lisado), se inmunoprecipitó la quinasa Plk3 con un anticuerpo anti-GST. En paralelo, se hizo como control una inmunoprecipitación inespecífica con un anticuerpo anti-AU5. El nivel de autofosforilación se observa en la autorradiografía (Figura $42 \mathrm{C},{ }^{32} \mathrm{P}$ ) y los 
niveles de proteína inmunoprecipitada se detectaron por inmunoblot. Se comprobó que la actividad de la quinasa Plk3, al igual que la actividad de MEK1 y de VRK1, era mayor en células en mitosis.

A
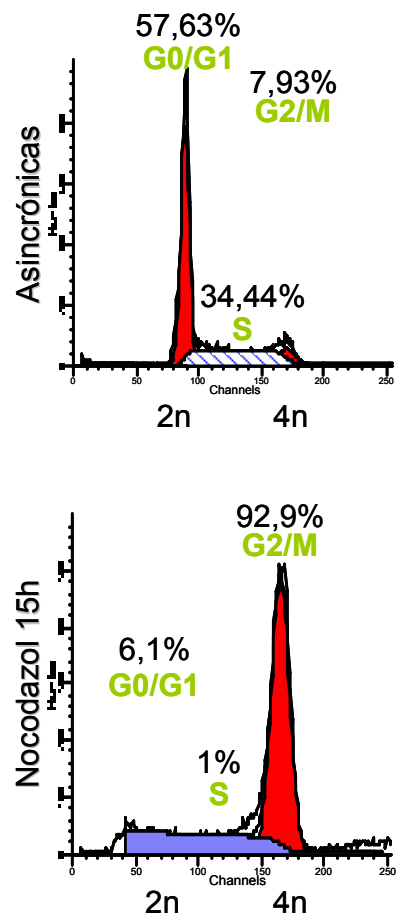

C
B

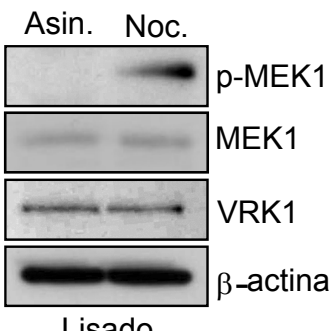

Lisado<smiles>CCOC</smiles>

IP: $\alpha-\mathrm{HA} \quad \alpha-\mathrm{VRK} 1$

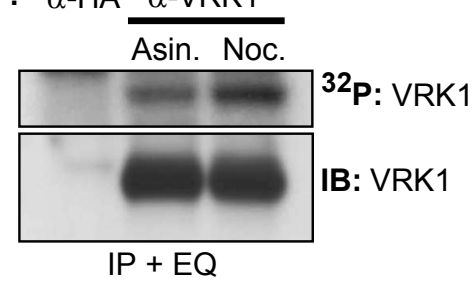

Asin. Noc.

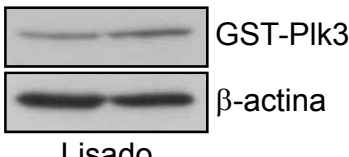

IP: $\alpha$-AU5 $\alpha-G S T$ Asin. Noc.

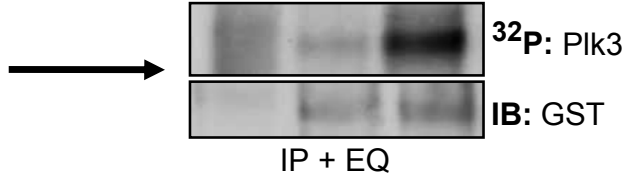

Figura 42. Correlación de los niveles de actividad de las quinasas MEK1, Plk3 y VRK1 en mitosis. A) Perfil de ciclo de células HeLa asincrónicas y en mitosis (nocodazol $83 \mathrm{nM}, 15 \mathrm{~h}$ ). B) Inmunoblot de células tratadas como en el apartado A. Se detectó el nivel de fosforilación de MEK1 (residuos Ser217/221) y el nivel de proteína de VRK1 y MEK1 (panel superior). Estos extractos se utilizaron para inmunoprecipitar VRK1 endógena (1F6) y realizar un ensayo quinasa in vitro (IP+EQ). Se muestra la autorradiografía $\left({ }^{32} \mathrm{P}\right)$ y el inmunoblot (IB) de VRK1. C) Se transfectó pCEFL-GST-PIk3 $(4 \mu \mathrm{g})$ en células HeLa y $24 \mathrm{~h}$ después se trataron con nocodazol (83 nM, $15 \mathrm{~h})$. La quinasa Plk3 se inmunoprecipitó y se sometió a un ensayo quinasa in vitro (IP+EQ). Se muestra la autofosforilación de Plk3 $\left({ }^{32} \mathrm{P}\right)$ y el nivel de proteína inmunoprecipitada por inmunoblot (IB). Asin.- asincrónicas; Noc.- nocodazol.

Para descartar que la activación de la quinasa VRK1 en mitosis fuera una consecuencia indirecta del tratamiento con nocodazol, y no debido a encontrarse en mitosis, se llevó a cabo un ensayo quinasa a una dosis alta de nocodazol y un tiempo 
corto de tratamiento ( $1 \mu \mathrm{g} / \mathrm{ml}, 150$ minutos) (Figura 43). Bajo estas condiciones, se produce un fuerte estrés en los microtúbulos que desencadena, por ejemplo, la fragmentación del aparato de Golgi (Figura 47) (Rogalski and Singer, 1984). Sin embargo, en estas condiciones la actividad quinasa de la proteína VRK1 endógena no se ve afectada (Figura $43,{ }^{32} \mathrm{P}$ ).

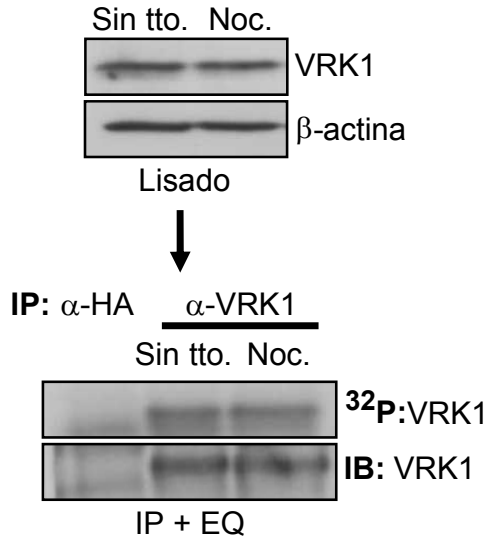

Figura 43. El tratamiento con nocodazol en sí, no afecta a la actividad quinasa de VRK1. Células HeLa fueron tratadas o no con nocodazol a $1 \mu \mathrm{g} / \mathrm{ml}$ durante 150 minutos. A continuación, se inmunoprecipitó la proteína VRK1 endógena con el anticuerpo $1 \mathrm{~F} 6$ y se hizo un ensayo quinasa in vitro con $\left[{ }^{32} \gamma-P\right]$ ATP (IP+EQ). Como control se hizo una inmunoprecipitación inespecífica con un anticuerpo anti-HA. Se comprobó la cantidad de VRK1 inmunoprecipitada con un anticuerpo policlonal (VC). Sin tto.- sin tratamiento; Noc.tratadas con nocodazol ( $1 \mu \mathrm{g} / \mathrm{ml}, 150$ minutos).

Este resultado, junto con el análisis de la actividad de VRK1 en mitosis y en fase G1 del ciclo celular indican, que, al menos, los niveles de proteína de VRK1 no varían entre mitosis y la fase $\mathrm{G} 1$, aunque su nivel de actividad sí lo hace. Además, su pico de activación en mitosis correlaciona con la activación de su quinasa upstream Plk3 y, a su vez, con la activación de MEK1 (Chase et al., 1998; Bahassi el et al., 2002). La ruta de señalización para la que se ha descrito a la quinasa Plk3 por debajo de MEK1 es la fragmentación del aparato de Golgi en mitosis (Xie et al., 2004). De este modo, más adelante se analizará directamente dicha ruta in vivo, pero por ahora, se demostrará si, efectivamente, VRK1 se sitúa downstream del módulo de señalización MEK1-Plk3.

\subsubsection{Análisis de la relación VRK1-MEK1.}

a) La sobreexpresión de MEK1 provoca un aumento de la actividad quinasa de VRK1 endógena.

La activación de la quinasa Plk3 consecuencia de la sobreexpresión de MEK1 ha sido demostrada (Xie et al., 2004). Además, en este trabajo se ha determinado que la sobreexpresión de Plk3, a su vez, induce la activación de la quinasa VRK1 endógena (Figura 35). De modo que, si Plk3 está situada bajo MEK1 y VRK1 está situada bajo 
Plk3, entonces la sobreexpresión de MEK1 debería activar también en cierta medida a VRK1.

Para determinar si este era el caso, se transfectó la proteína MEK1 silvestre, que es activa (ver figura 46), en la línea celular HeLa y se inmunoprecipitó la proteína VRK1 endógena con un anticuerpo policlonal (VC) (Figura 44). Al comparar el nivel de autofosforilación de VRK1 en la autorradiografía $\left({ }^{32} \mathrm{P}\right)$, se detectó un incremento en su actividad tras la sobreexpresión de la quinasa MEK1 con respecto a la actividad tras la transfección con un vector vacío (pCEFL-HAØ). La cantidad de proteína VRK1 inmunoprecipitada se corroboró por inmunoblot con un anticuerpo monoclonal (1F6).

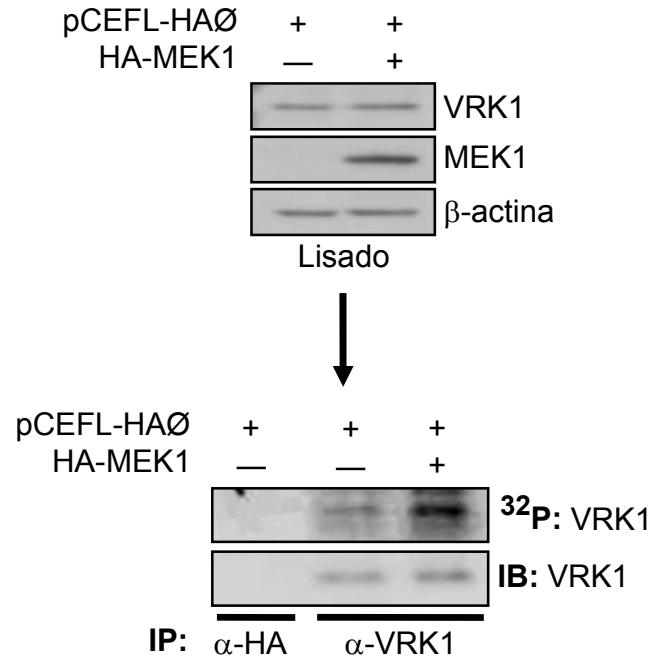

Figura 44. Actividad de VRK1 tras la sobreexpresión de MEK1. La línea celular HeLa fue transfectada con $5 \mu \mathrm{g}$ de pCEFLHA-MEK1 o de vector vacío pCEFL-HAØ. La expresión de HA-MEK1 y VRK1 endógena se comprobó por inmunoblot con los anticuerpos anti-HA y 1F6, respectivamente (panel superior). Estos extractos fueron usados para inmunoprecipitar VRK1 endógena con un anticuerpo policlonal (VC) y, a continuación, se llevó a cabo un ensayo quinasa in vitro en presencia de $\left[{ }^{32} \gamma\right.$-P] ATP (panel inferior). Como control se realizó una inmunoprecipitación inespecífica con un anticuerpo anti-HA.

\section{b) Efecto del inhibidor PD98059 sobre la actividad de VRK1.}

Teniendo en cuenta que la sobreexpresión de MEK1 parece activar a la quinasa VRK1 (Figura 44), se pensó que una forma diferente de abordar la hipótesis de la ruta MEK1PIk3-VRK1 sería utilizar un inhibidor específico de MEK1 y determinar qué le ocurre a la actividad de VRK1. Uno de los inhibidores mejor caracterizados de MEK1 es el denominado PD98059. Este inhibidor se caracteriza por ser no competitivo con el ATP y bloquear la activación de MEK1 por sus quinasas upstream (Alessi et al., 1995; Dudley et al., 1995). Así, se realizaron dos ensayos respecto a VRK1, uno in vitro y otro in vivo. En el primero, se llevó a cabo un ensayo quinasa in vitro utilizando VRK1 purificada en presencia de dos concentraciones del inhibidor (Figura 45A). Como se puede apreciar en la autorradiografía $\left({ }^{32} \mathrm{P}\right)$, la autofosforilación de VRK1 no se ve afectada por el inhibidor en el ensayo in vitro (Figura 45A). Sin embargo, al tratar células HeLa en cultivo con una concentración no tóxica de $25 \mu \mathrm{M}$ del inhibidor y 
analizar la actividad quinasa de la proteína VRK1 endógena inmunoprecipitada, se detectó una inhibición parcial de la actividad (Figura 45B).

Estos datos sugieren que la quinasa VRK1 se sitúa por debajo de MEK1 y que un inhibidor específico de esta como el PD98059, al igual que inhibe la actividad de Plk3 (Xie et al., 2004), tiene un ligero efecto sobre la actividad de VRK1 in vivo pero no in vitro, lo que indicaría que el inhibidor no actúa directamente sobre VRK1 sino sobre un activador suyo situado upstream (ver modelo en la figura 45C).

A

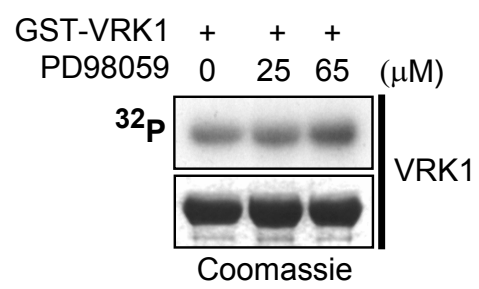

C

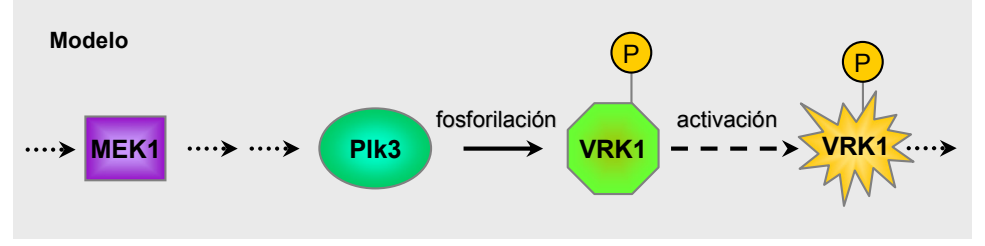

B

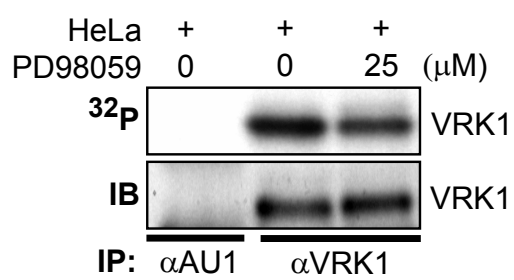

IP: $\alpha \mathrm{AU1} \quad \alpha \mathrm{VRK} 1$

Figura 45. El inhibidor PD98059 inhibe parcialmente la actividad de VRK1 in vivo pero no in vitro. A) Ensayo quinasa in vitro. Se llevó a cabo un ensayo quinasa in vitro con proteína purificada de VRK1. Se hizo en ausencia o presencia del inhibidor PD98059 y se detectó la actividad de autofosforilación de VRK1. El grado de autofosforilación se muestra en la autorradiografía $\left({ }^{32} \mathrm{P}\right)$ y el nivel de proteína en la tinción con azul de Coomassie. B) Efecto del inhibidor PD98059 sobre VRK1 de células HeLa. Se crecieron células HeLa en ausencia o presencia del inhibidor PD98059 (25 $\mu \mathrm{M}, 12 \mathrm{~h})$. A continuación, se inmunoprecipitó VRK1 con un anticuerpo monoclonal (1F6) y se llevó a cabo un ensayo quinasa in vitro. El grado de autofosforilación de VRK1 se muestra en la autorradiografía $\left({ }^{32} \mathrm{P}\right)$ y el nivel de proteína inmunoprecipitada en un inmunoblot. C) Esquema resumen de la relación entre las quinasas MEK1, Plk3 y VRK1.

\section{c) VRK1 no es sustrato de MEK1.}

Para descartar que la regulación de VRK1 in vivo en relación con MEK1 no era la consecuencia directa de una fosforilación, sino que era un efecto indirecto debido a su posición downstream respecto de ella, se realizó un ensayo quinasa in vitro utilizando MEK1 inmunoprecipitada de células y VRK1 ${ }^{\mathrm{K} 179 \mathrm{E}}$ purificada (Figura 46). La quinasa MEK1 se inmunoprecipitó con un anticuerpo monoclonal frente al epítopo HA y se utilizó en un ensayo quinasa en presencia de $\left[{ }^{32} \gamma\right.$-P] ATP. En la autorradiografía $\left({ }^{32} \mathrm{P}\right)$ se observa la autofosforilación de MEK1 y, sin embargo, no se detecta señal a la altura 
de la proteína VRK1 ${ }^{\mathrm{K} 179 \mathrm{E}}$. Los niveles de las proteínas del ensayo se comprobaron por inmunoblot usando anticuerpos anti-GST y anti-HA.

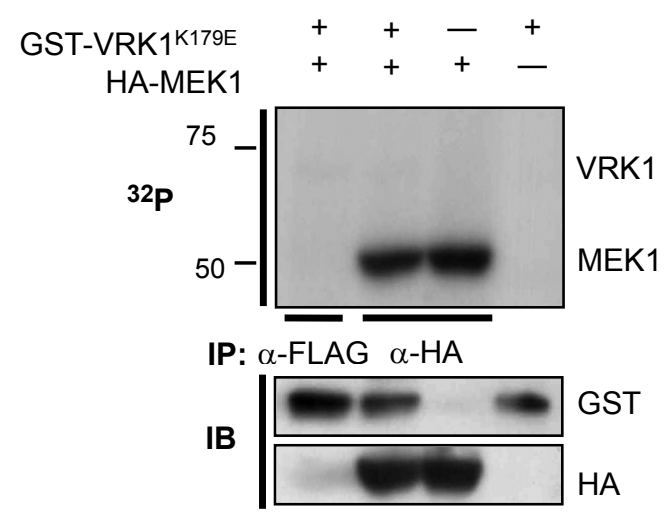

Figura 46. La quinasa MEK1 no fosforila a VRK1. Células HEK293T fueron transfectadas con $3 \mu \mathrm{g}$ de pCEFL-HA-MEK1. 36h después, MEK1 fue inmunoprecipitada (IP) con un anticuerpo monoclonal anti-HA y se realizó un ensayo quinasa in vitro utilizando como sustrato la proteína $\mathrm{VRK} 1^{\mathrm{K} 179 \mathrm{E}}$ purificada. Se muestra la autorradiografía $\left({ }^{32} \mathrm{P}\right)$ y los niveles de proteína inmunoprecipitada y de sustrato (IB). Como control se hizo una inmunoprecipitación inespecífica con un anticuerpo anti-FLAG.

A la vista de los resultados se puede concluir que VRK1 no es sustrato de MEK1 pero se sitúa downstream de esta y de la quinasa Plk3 estableciéndose el módulo de señalización MEK1-Plk3-VRK1 (ver modelo en la figura 45C).

\subsubsection{Comportamiento de la proteína VRK1 asociada al aparato de}

\section{Golgi tras el tratamiento con nocodazol, brefeldina A y ácido okadaico.}

Una de las herramientas más usadas en el estudio de la biología del aparato de Golgi ha sido la utilización de agentes farmacológicos como, por ejemplo, el nocodazol, la brefeldina $A(B F A)$ y el ácido okadaico (AO), que a través de distintos mecanismos llevan a la fragmentación del aparato de Golgi de células en interfase (Dinter and Berger, 1998). El nocodazol provoca la fragmentación del aparato de Golgi debido a que desensambla los microtúbulos (Rogalski and Singer, 1984). La brefeldina A, por su parte, bloquea el transporte de vesículas lo que termina en el colapso de las enzimas del aparato de Golgi en el retículo endoplasmático, mientras que las proteínas de la matriz del aparato de Golgi se dispersan por el citoplasma (Lippincott-Schwartz et al., 1989; Seemann et al., 2000a; Seemann et al., 2002). Por último, el ácido okadaico es un inhibidor de serina-treonina fosfatasas tipo 1, 2A y $2 \mathrm{~B}$ que también provoca el colapso del aparato de Golgi, aunque su mecanismo de acción no se conoce (Lucocq et al., 1995). En todos los casos, este fenómeno de fragmentación es reversible en tiempos relativamente cortos.

La quinasa VRK1 localizada en el aparato de Golgi permanece asociada a sus fragmentos durante la mitosis, fenómeno que se identificó en la figura 27 (pág. 67). Por 
su parte, Plk3 también forma un complejo estable con el aparato de Golgi tanto en interfase como en mitosis e incluso tras el tratamiento con nocodazol o brefeldina $\mathrm{A}$ presumiblemente a través de su interacción con la proteína Giantina (Ruan et al., 2004). Con todos estos antecedentes, se quiso determinar si la subpoblación de VRK1 asociada al aparato de Golgi, que se comporta de un modo similar a la quinasa Plk3 en mitosis, también seguía un patrón similar tras el tratamiento con distintos agentes que desorganizan el sistema continuo de membranas que es el aparato de Golgi en interfase.

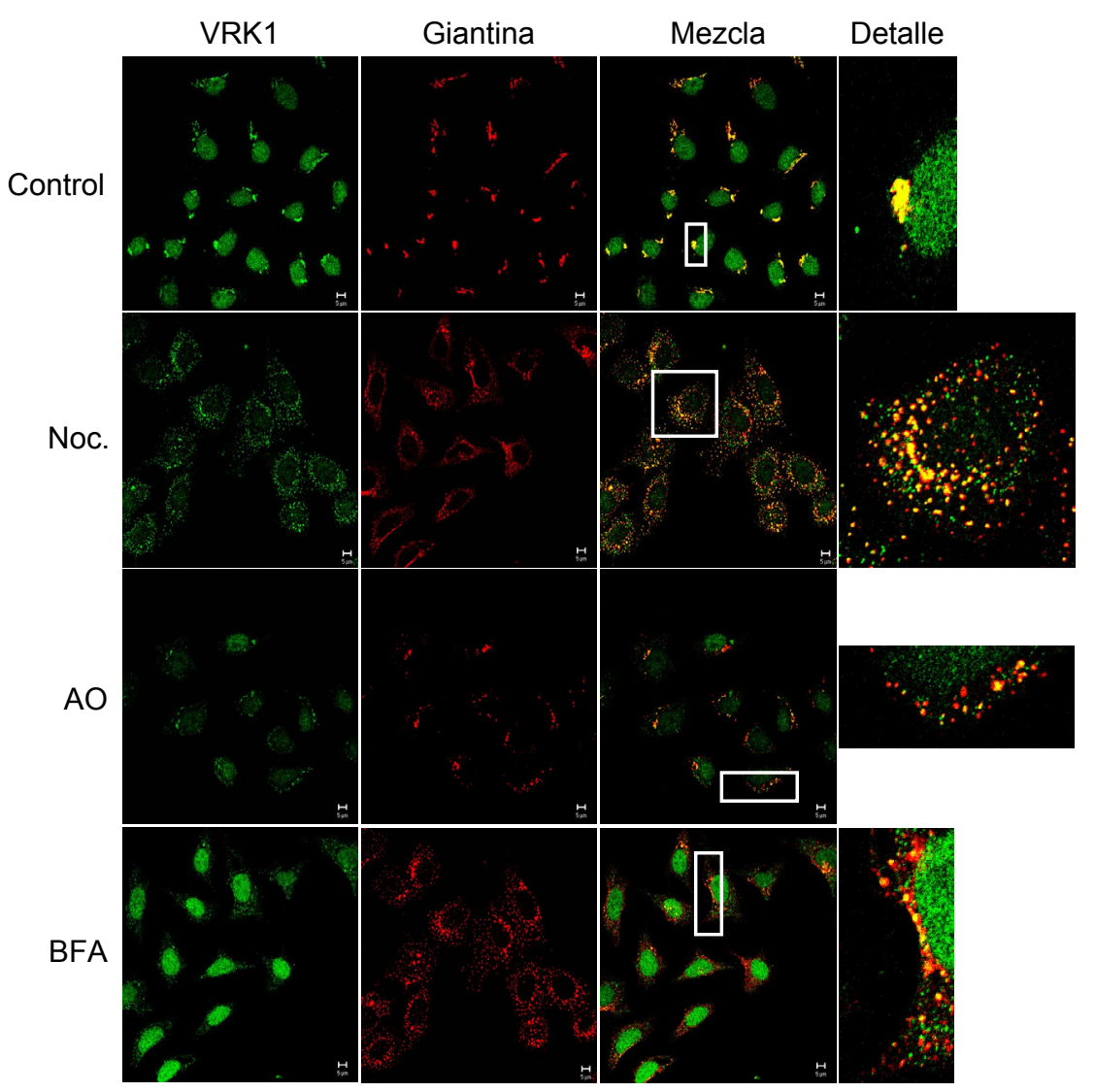

Figura 47. Fenotipo del aparato de Golgi tras el tratamiento con nocodazol (Noc.), ácido okadaico (AO) y brefeldina A (BFA) en células HeLa. Las células fueron tratadas con nocodazol $(1 \mu \mathrm{g} / \mathrm{ml}, 150 \mathrm{~min}$.), ácido okadaico $(1 \mu \mathrm{M}, 60 \mathrm{~min}$.) o brefeldina $\mathrm{A}(5 \mu \mathrm{g} / \mathrm{ml}, 90 \mathrm{~min}$.). La quinasa VRK1 fue detectada con un anticuerpo monoclonal (1F6- verde) y el aparato de Golgi con uno policlonal (Giantina- rojo). El ADN se tiñó con DAPI (azul). La barra indica $5 \mu \mathrm{m}$. Se muestra detalle de una célula para ver el solapamiento de la señal de ambos anticuerpos.

Para ello, se hicieron dos aproximaciones. Por un lado, se analizó la población de VRK1 utilizando el anticuerpo monoclonal 1F6 (verde) respecto a un marcador del aparato de Golgi (Giantina- rojo) tras el tratamiento con nocodazol, ácido okadaico y brefeldina A (Figura 47) y, por otro lado, se realizó un experimento de wash-out y se 
observó cómo se recuperaba la estructura del aparato de Golgi tras la eliminación, en este caso, del nocodazol (Figura 48). Se pudo comprobar que VRK1, tanto en células HeLa como, por ejemplo, en células WS1 (datos no mostrados), permanece asociada a los fragmentos del aparato de Golgi tras el tratamiento con los distintos agentes farmacológicos (Figura 47).

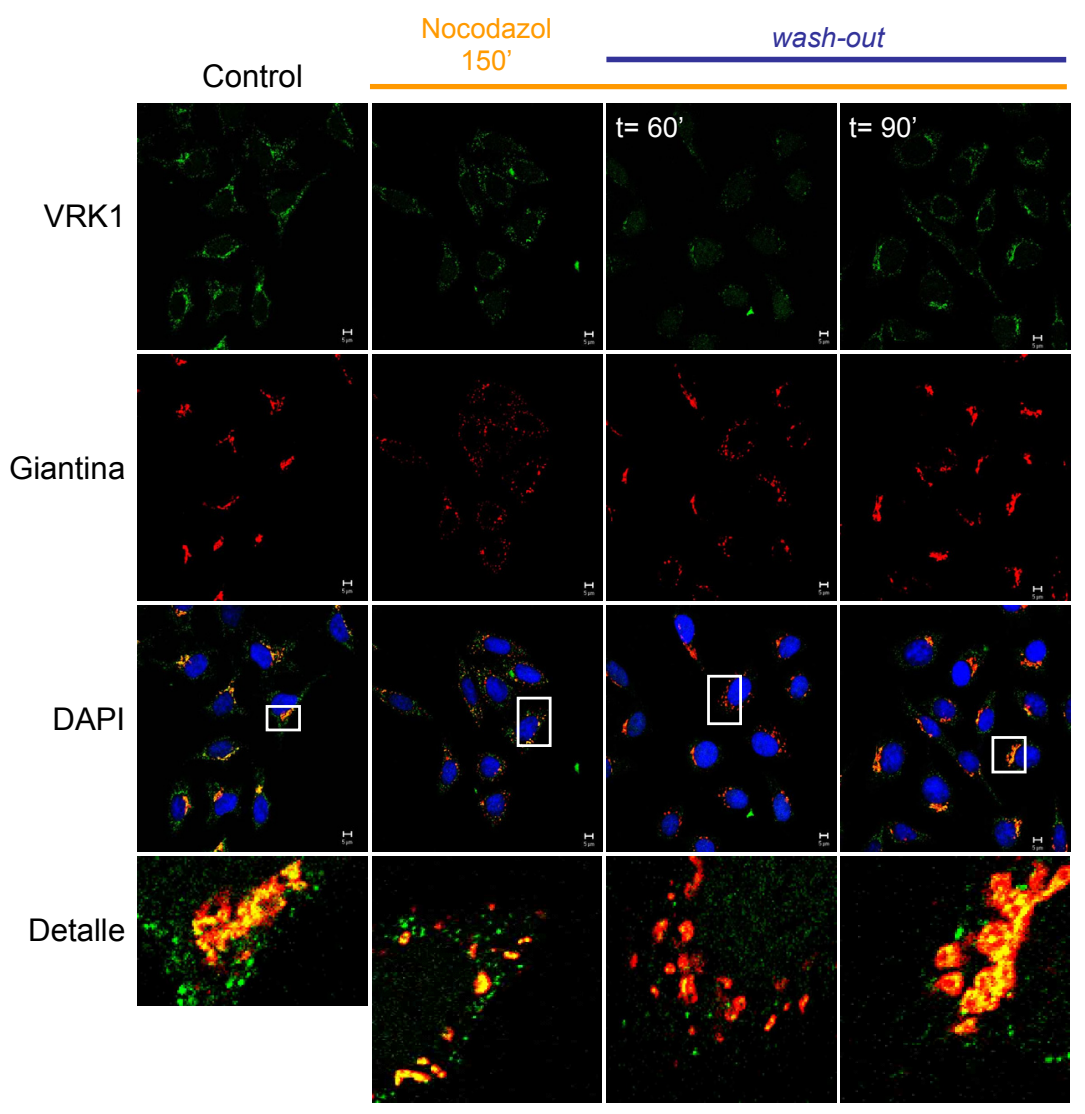

Figura 48. El aparato de Golgi recupera su estructura 90 minutos después de la retirada del nocodazol. Se realizó un experimento de wash-out en el que células HeLa fueron tratadas con nocodazol (1 $\mu \mathrm{g} / \mathrm{ml}, 150$ '). A continuación, las células fueron lavadas varias veces con PBS y se les añadió medio fresco, recogiendo puntos a distintos tiempos $\left(30^{\prime}, 60^{\prime}, 90^{\prime}\right.$ y $\left.120^{\prime}\right)$. Se muestran los resultados para 60' y 90'. Se detectó VRK1 con un anticuerpo monoclonal (1F6- verde) y el aparato de Golgi con uno policlonal (Giantina- rojo). El ADN se tiñó con DAPI (azul). Se muestra detalle de una célula para ver el solapamiento de la señal de ambos anticuerpos. La barra indica 5 $\mu \mathrm{m}$.

En el caso del ensayo de wash-out, las células HeLa fueron tratadas con nocodazol $(1 \mu \mathrm{g} / \mathrm{ml})$ durante 150 minutos y, tras lavarlas varias veces, se les añadió medio fresco y se recogieron puntos a distintos tiempos. Las células fueron teñidas para inmunofluorescencia con un anticuerpo monoclonal para VRK1 (1F6- verde) y uno policlonal para Giantina (rojo) (Figura 48). Como se puede apreciar en este ensayo, la quinasa VRK1 permanece asociada en todo momento a las membranas del 
aparato de Golgi tanto en las células control como en las células tratadas con nocodazol y los distintos tiempos de wash-out.

Estos ensayos y el análisis de la localización de VRK1 a lo largo del ciclo celular (Figura 27) sugieren que la quinasa VRK1 está asociada de un modo estable con las membranas del aparato de Golgi tanto ensambladas como fragmentadas, al igual que su quinasa upstream Plk3 (Dai et al., 2002b; Ruan et al., 2004; Xie et al., 2004).

\subsubsection{VRK1 es necesaria para la fragmentación del aparato de Golgi} inducida por MEK1 y por PIk3.

Los resultados hasta el momento obtenidos indican que, efectivamente, la quinasa VRK1 constituye un nuevo elemento en un módulo de señalización formado por MEK1-PIk3, donde VRK1 sería la quinasa situada por debajo de ambas. Sin embargo, las aproximaciones llevadas a cabo no aportan todavía datos del proceso biológico in vivo en el que estaría implicada. En concreto, las quinasas MEK1 y Plk3 son parte de la señalización que desencadena la fragmentación del aparato de Golgi en la transición G2/M del ciclo celular (Xie et al., 2004; Feinstein and Linstedt, 2007). Con todo ello, el siguiente paso fue analizar la implicación de VRK1 en dicha ruta.

Para ello, se llevaron a cabo ensayos de sobreexpresión y se analizó el fenotipo del aparato de Golgi detectándolo por inmunofluorescencia con un anticuerpo policlonal para Giantina (rojo) e identificando las células transfectadas con GFP (verde). Lo primero fue comprobar que, en efecto, se detectaba lo que ya había sido descrito: por un lado, que la sobreexpresión de MEK1 induce la fragmentación del aparato de Golgi en células en interfase y que, sin embargo, en células previamente tratadas con un inhibidor específico de MEK1 (PD98059, $20 \mu \mathrm{M}$ ) se evitaba dicha fragmentación (Figura 49A, panel b y c) (Xie et al., 2004) y, por otro, que la quinasa inactiva PIk3 ${ }^{K 52 R}$ también bloquea la fragmentación inducida por MEK1 (Figura 49A, panel d), situándola por debajo de esta en la ruta de señalización que desencadena este proceso (Xie et al., 2004). Se analizó entonces qué ocurría al cotransfectar la quinasa inactiva VRK1 ${ }^{\mathrm{K} 179 \mathrm{E}}$ con MEK1. Como se aprecia en el panel e (Figura 49A), la proteína VRK1 sin actividad quinasa bloquea el proceso en un grado similar a la quinasa Plk3 inactiva (ver gráfica de la figura 49A). 
A

Giantina

GFP
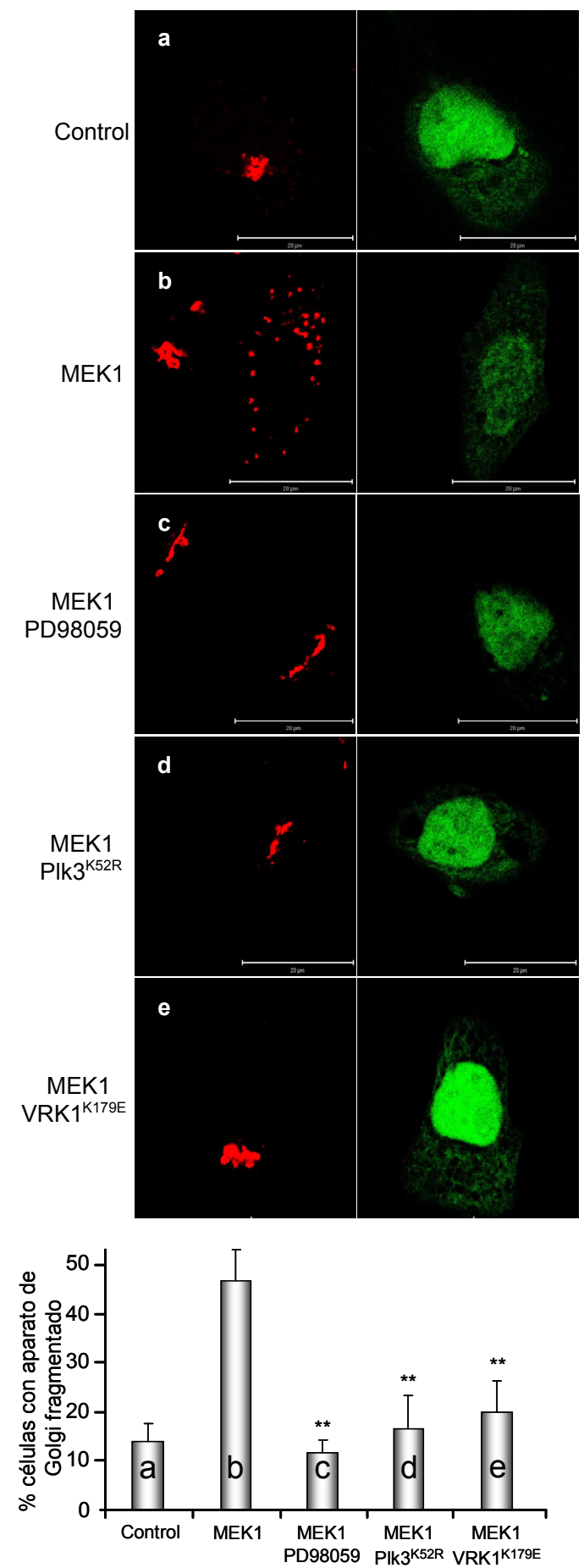

B

Giantina

GFP
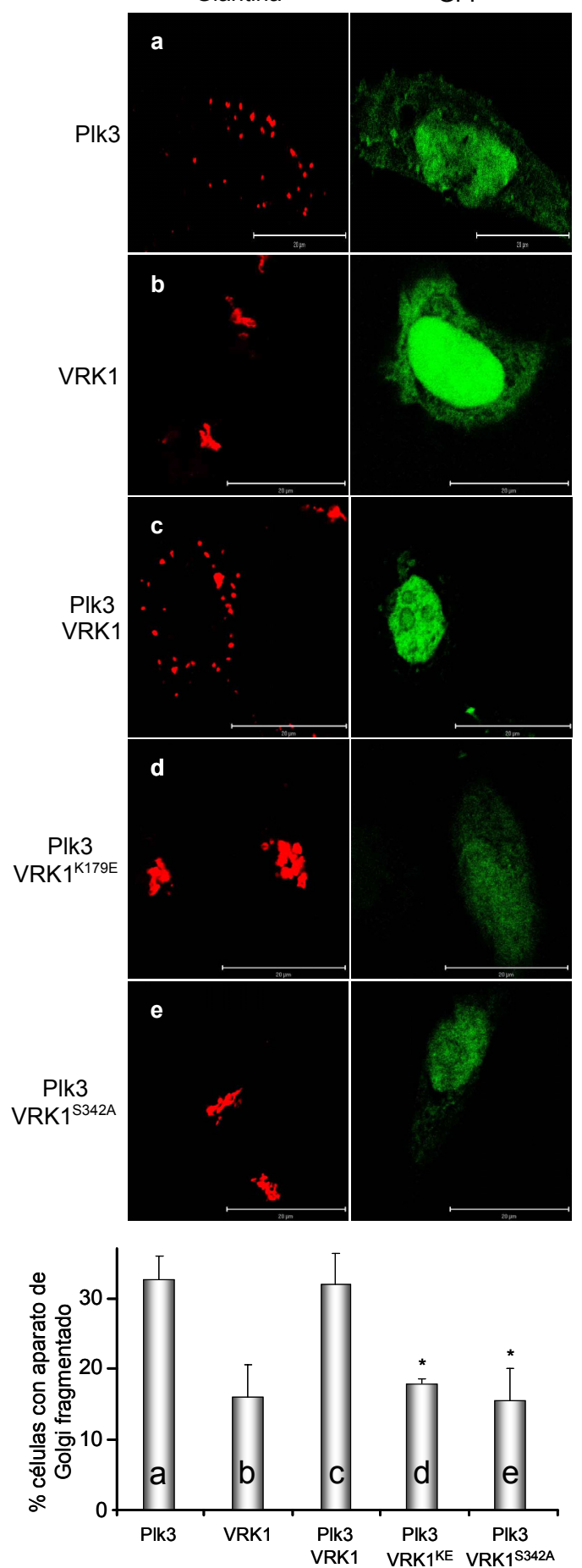

Figura 49. El mutante VRK1 ${ }^{\mathrm{K} 179 \mathrm{E}}$ evita la fragmentación del aparato de Golgi inducida por MEK1 (A) y los mutantes VRK1 ${ }^{\mathrm{K} 179 \mathrm{E}}$ y VRK1 ${ }^{3342 \mathrm{~A}}$ evitan la fragmentación del aparato de Golgi inducida por Plk3 (B). Se transfectaron células HeLa con las proteínas indicadas en cada panel. La proteína MEK1 utilizada fue un mutante constitutivamente activo. El inhibidor PD98059 se utilizó a $20 \mu \mathrm{M}$. El control del ensayo fue una transfección con vector vacío pEGFP-N1Ø. El fenotipo del aparato de Golgi se detectó por inmunofluorescencia con un anticuerpo para Giantina (rojo). Se muestra una gráfica con el porcentaje de células con el aparato de Golgi fragmentado en cada caso. Se representa la media de tres experimentos con $\mathrm{N}=100$, analizados con $\mathrm{t}$ de Student respecto al control con vector vacío. ${ }^{* *}, p<0,005 .{ }^{*}, p<0,05$. La barra indica $20 \mu \mathrm{m}$. 
Las imágenes mostradas en la figura 49 son representativas del experimento y por eso se acompañan de una gráfica que resume los resultados obtenidos para cada caso. Como se observa en la gráfica de la figura 49A, el porcentaje de células con el aparato de Golgi fragmentado aumenta drásticamente tras la sobreexpresión de MEK1 y se reduce casi a su valor de partida, respecto del control de transfeccción con un vector vacío (Figura 49A, panel a), tanto en presencia del inhibidor como de las quinasas Plk3 y VRK1 sin actividad quinasa.

A continuación, se analizó el fenotipo del aparato de Golgi tras la sobreexpresión de Plk3 silvestre y de distintas construcciones de VRK1 (Figura 49B). La sobreexpresión de Plk3 induce la fragmentación del aparato de Golgi (Xie et al., 2004), a diferencia de la quinasa VRK1 silvestre que por sí sola no tiene efecto (Figura 49B, paneles a y b). Además, la quinasa VRK1 inactiva pero no silvestre bloquea la fragmentación del aparato de Golgi inducida por Plk3 (Figura 49B, paneles c y d), lo que significa que la actividad quinasa de VRK1 es necesaria para que se transmita la señal. Por último, se decidió hacer un mutante no fosforilable del residuo diana de Plk3 $\left(\mathrm{VRK} 1^{\mathrm{S} 342 \mathrm{~A}}\right)$ y cotransfectarlo con la quinasa Plk3 silvestre. En este caso, la fragmentación provocada por Plk3 es bloqueada por el mutante VRK1 ${ }^{\mathrm{S} 342 \mathrm{~A}}$ (Figura 49B, panel e) lo que confirma que VRK1 se sitúa por debajo de Plk3 y que la fosforilación en la serina 342 parece ser clave en el proceso. Para estos experimentos de sobreexpresión también se muestra la gráfica resumen correspondiente y se observa que, efectivamente, la quinasa Plk3 induce fragmentación respecto al control con un vector vacío (Figura 49A, panel a) aunque el efecto es menos drástico, quizás porque en el caso de la quinasa MEK1 se utilizó un mutante constitutivamente activo $\left(\mathrm{MEK} 1^{\mathrm{S} 218 / 222 \mathrm{E}, \Delta 32-51}\right.$ ) y, sin embargo, de la quinasa Plk3 se usó la proteína silvestre.

El número medio máximo y tamaño mínimo de los fragmentos de aparato de Golgi en mitosis en células HeLa es de 130 fragmentos y de 0,5-1 $\mu \mathrm{m}$ (Shima et al., 1997; Shima et al., 1998). Los valores obtenidos tras la sobreexpresión de MEK1 y Plk3 (Figura 49), calculados utilizando el programa ImageJ (http://rsb.info.nih.gov/ii), son de 30-45 fragmentos con un tamaño de 1,5-2 $\mu \mathrm{m}$, lo que sugiere que se reproduce parcialmente el proceso de fragmentación, lo cual es lógico ya que existen otras rutas de señalización que participan en el proceso.

Como la quinasa VRK1 silvestre no es capaz por sí sola de inducir la fragmentación del aparato de Golgi, se decidió hacer un mutante mimético de fosforilación en la serina $342\left(\mathrm{VRK} 1^{\mathrm{S} 342 \mathrm{D}}\right)$, que es el residuo fosforilado por Plk3, y determinar si esta proteína era capaz de reproducir el efecto. Previo a los ensayos de 
sobreexpresión, se realizó un ensayo quinasa in vitro y se analizó la actividad quinasa de los mutantes VRK1 $1^{\mathrm{S} 342 \mathrm{~A}}$ y $\mathrm{VRK} 1^{\mathrm{S} 342 \mathrm{D}}$ en comparación con la quinasa silvestre para estar seguros de que la mutación puntual generada en cada caso no afectaba a la actividad de la quinasa, medida a través de su capacidad de autofosforilación (Figura 50A). Así, se transfectaron células HEK293T con las proteínas VRK1 silvestre,

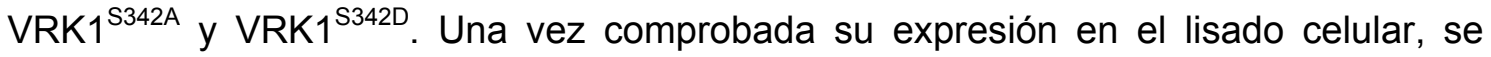
realizó una inmunoprecipitación con un anticuerpo anti-HA y un ensayo quinasa in vitro $\left(\mathrm{IP}+\mathrm{EQ}\right.$ ). Como se puede ver en la autorradiografía (Figura $50 \mathrm{~A},{ }^{32} \mathrm{P}$ ) todas las proteínas son activas. A continuación, se realizaron experimentos de sobreexpresión con las distintas proteínas en la línea celular HeLa y se observó que la quinasa VRK1 silvestre no induce fragmentación, al igual que el mutante VRK1 ${ }^{\mathrm{S} 342 \mathrm{~A}}$ (Figura 50B, paneles a y b). Sin embargo, la sobreexpresión del mutante que mimetiza la fosforilación en serina 342 por Plk3 (VRK1 ${ }^{\text {S342D }}$ ) induce dicho proceso (Figura 50B, panel c). En la figura $50 \mathrm{C}$ se muestra una gráfica resumen con las cuantificaciones de los ensayos realizados.

A

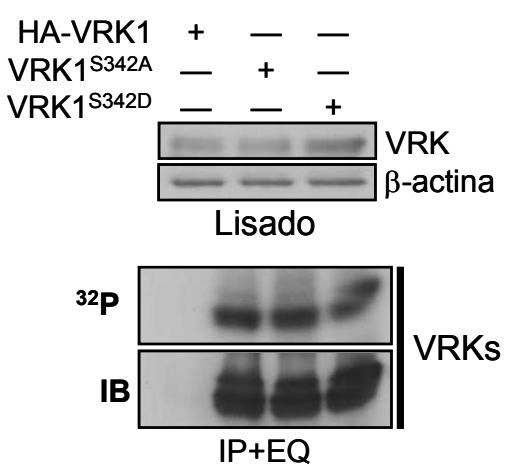

C

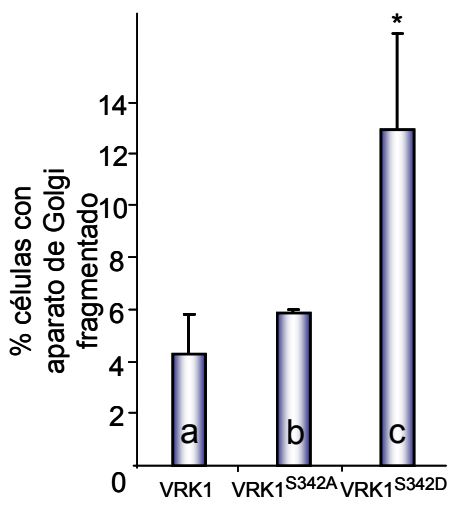

B

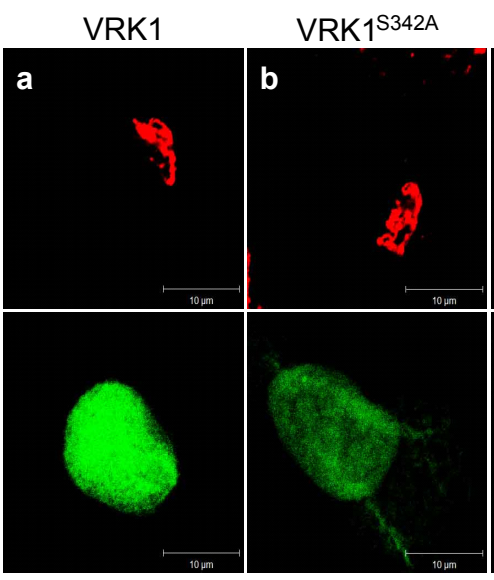

Figura 50. Efecto de la sobreexpresión de VRK1 ${ }^{5342 D}$ sobre el aparato de Golgi. A) Ensayo quinasa in vitro de cada proteína inmunoprecipitada con un anticuerpo monoclonal anti-HA. Se muestra la autorradiografía $\left({ }^{32} \mathrm{P}\right)$ y la cantidad de proteína inmunoprecipitada (IB). B) Sobreexpresión en células HeLa de pCEFL-HA-VRK1, pCEFL-HA-VRK1 $1^{\text {S342A y pCEFL-HA-VRK1 }}{ }^{\text {S342D. Se }}$ analizó el fenotipo del aparato de Golgi detectándolo con un anticuerpo para Giantina (rojo). Las células transfectadas se identificaron con GFP. C) Gráfica de la cuantificación del porcentaje de células con el aparato de Golgi fragmentado en cada caso. Se representa la media de tres experimentos con $\mathrm{N}=100$, analizados con t de student respecto a VRK1. *, $p<0,05$. 
Por lo tanto, se puede concluir que la fragmentación inducida tanto por MEK1 como por Plk3 es bloqueada por la quinasa inactiva $\mathrm{VRK} 1^{\mathrm{K} 179 \mathrm{E}}$. Esto indica que su actividad quinasa es necesaria y sugiere que, posiblemente, tiene uno o varios sustratos que desencadenan el proceso. Además, el mutante VRK $1^{\mathrm{S} 342 \mathrm{~A}}$, incapaz de fosforilarse por su quinasa upstream Plk3, también bloquea el efecto de esta, lo que sitúa a VRK1 en la ruta y a dicha fosforilación como modificación postraduccional clave. Por último, el hecho de que la sobreexpresión del mutante VRK1 ${ }^{\text {S342D }}$ sea capaz de inducir la fragmentación del aparato de Golgi, corrobora la importancia de dicha fosforilación.

Para confirmar que, en efecto, VRK1 es el componente situado al final de la ruta MEK1-PIk3 que lleva a la fragmentación del aparato de Golgi, se realizaron experimentos de sobreexpresión de MEK1 y Plk3 en células HeLa previamente deplecionadas de la quinasa VRK1 mediante dos sistemas distintos de ARN de interferencia. En uno de ellos, se utilizaron dúplex de ARN de interferencia (siVRK1) (Figura 51) y, en el otro, se usó el sistema pSUPER, que es un vector de expresión para eucariotas que dirige la síntesis de ARN de interferencia dentro de las células (shVRK1) (Figura 52).

En el primer ensayo, las células HeLa fueron transfectadas con oligonucleótidos de ARN de interferencia específicos para VRK1 (siVRK1) o con oligonucleótidos sin diana específica como control negativo (siControl). La eficiencia de los oligos de ARN de interferencia para VRK1 había sido demostrada previamente (Vega et al., 2004). En la línea celular HeLa se obtiene una bajada drástica de los niveles de la proteína VRK1 a los 4 días de transfeccción (Figura 51B). Por lo tanto, las células fueron retransfectadas 4 días después con MEK1 o Plk3 y se fijaron 15 horas o 13 horas después, respectivamente. Se observó que el aparato de Golgi, identificado por la tinción de la proteína GM130 (rojo), se fragmentaba tanto en células transfectadas con MEK1 como con Plk3 en células con siControl (Figura 51A, paneles b y d). Sin embargo, en las células deficientes en VRK1 (siVRK1), la fragmentación del aparato de Golgi, inducida por MEK1 y Plk3 era bloqueada (Figura 51A, paneles c y e).

Se muestra una imagen de las células HeLa en cultivo tras el tratamiento con el ARN de interferencia control (siControl) con respecto al ARN de interferencia específico para VRK1 (siVRK1) a los cuatro días (Figura 51C) y se puede observar cómo el número de células en ausencia de VRK1 es menor. Además, para analizar más en profundidad el efecto de la supresión de VRK1 sobre la fragmentación del aparato de Golgi inducida por MEK1 y Plk3, se procedió a la cuantificación del número 
de fragmentos de aparato de Golgi (objetos) por célula en las distintas condiciones de la figura $51 \mathrm{~A}$. Se analizaron unas 20 células por punto y por triplicado mediante el programa ImageJ, de modo que se determinó que el número medio de fragmentos inducido por la sobreexpresión de MEK1 era de 45 objetos por célula mientras que Plk3 inducía en torno a 30 objetos por célula. Sin embargo, las células transfectadas con siVRK1 presentaban una reducción en el número de objetos por célula significativo, tanto tras la activación por MEK1 como por PIk3 (representado en la figura 51D).
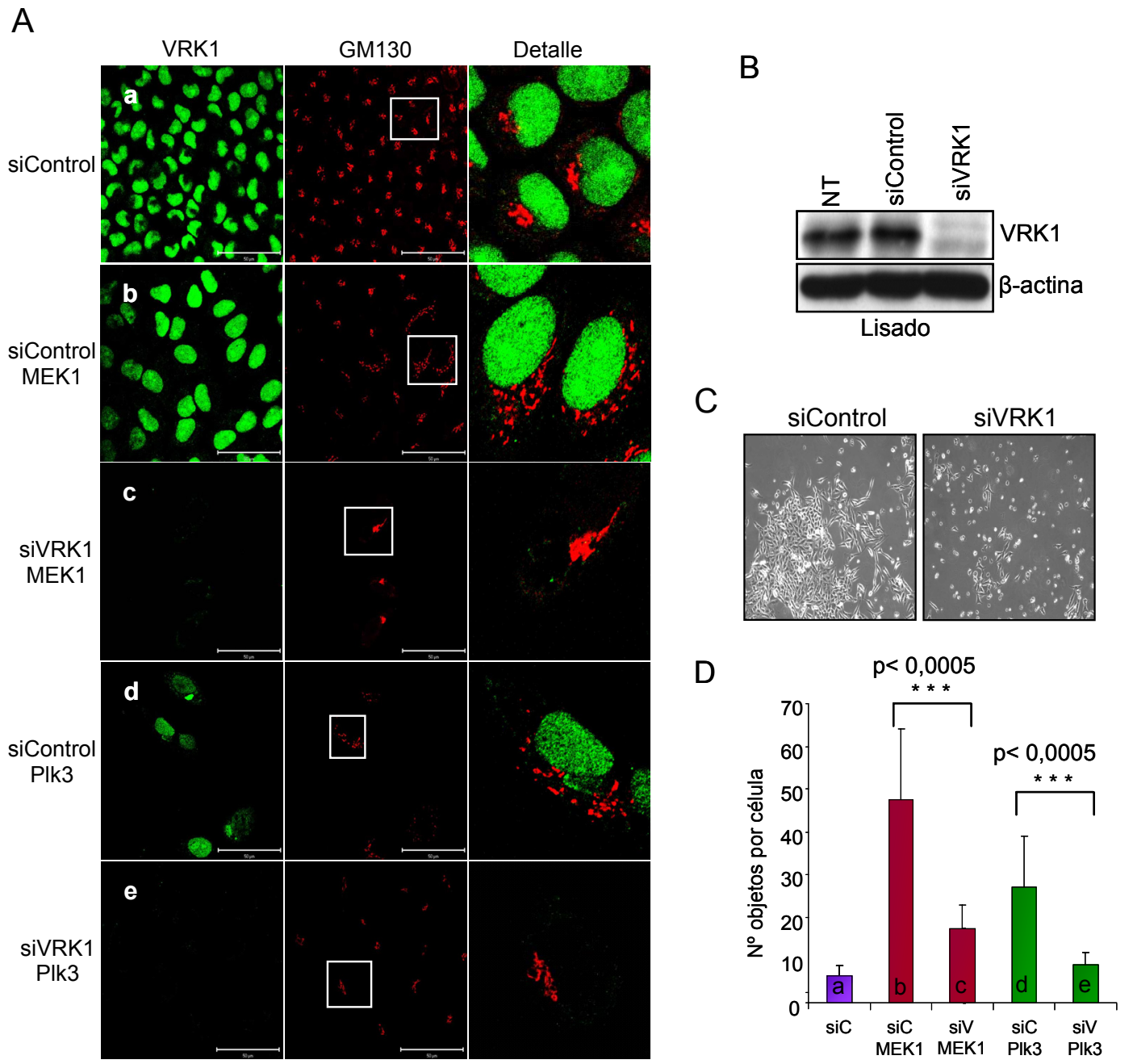

Figura 51. Efecto de la supresión de la expresión de VRK1 por ARN de interferencia. A) Fenotipo del aparato de Golgi. Se transfectaron células HeLa con ARN de interferencia específico para VRK1 (siVRK1) o ARN control (siControl). 4 días después, se retransfectaron las proteínas indicadas en la figura. VRK1 se detectó con un anticuerpo policlonal (VC- verde) y el aparato de Golgi con uno monoclonal (GM130- rojo). La barra indica $50 \mu \mathrm{m}$. B) Inmunoblot de VRK1. Se verificó la eficiencia del ARN de interferencia por inmnublot. NT, no transfectado. C) Imágenes de células HeLa en cultivo. Se hicieron fotos de células HeLa sometidas a la transfeccción con ARN de interferencia. D) Cuantificación del grado de fragmentación del aparato de Golgi (número de objetos) mediante el programa ImageJ (http://rsb.info.nih.gov/ii). Se representa la media de tres experimentos con $\mathrm{N}=20$. 


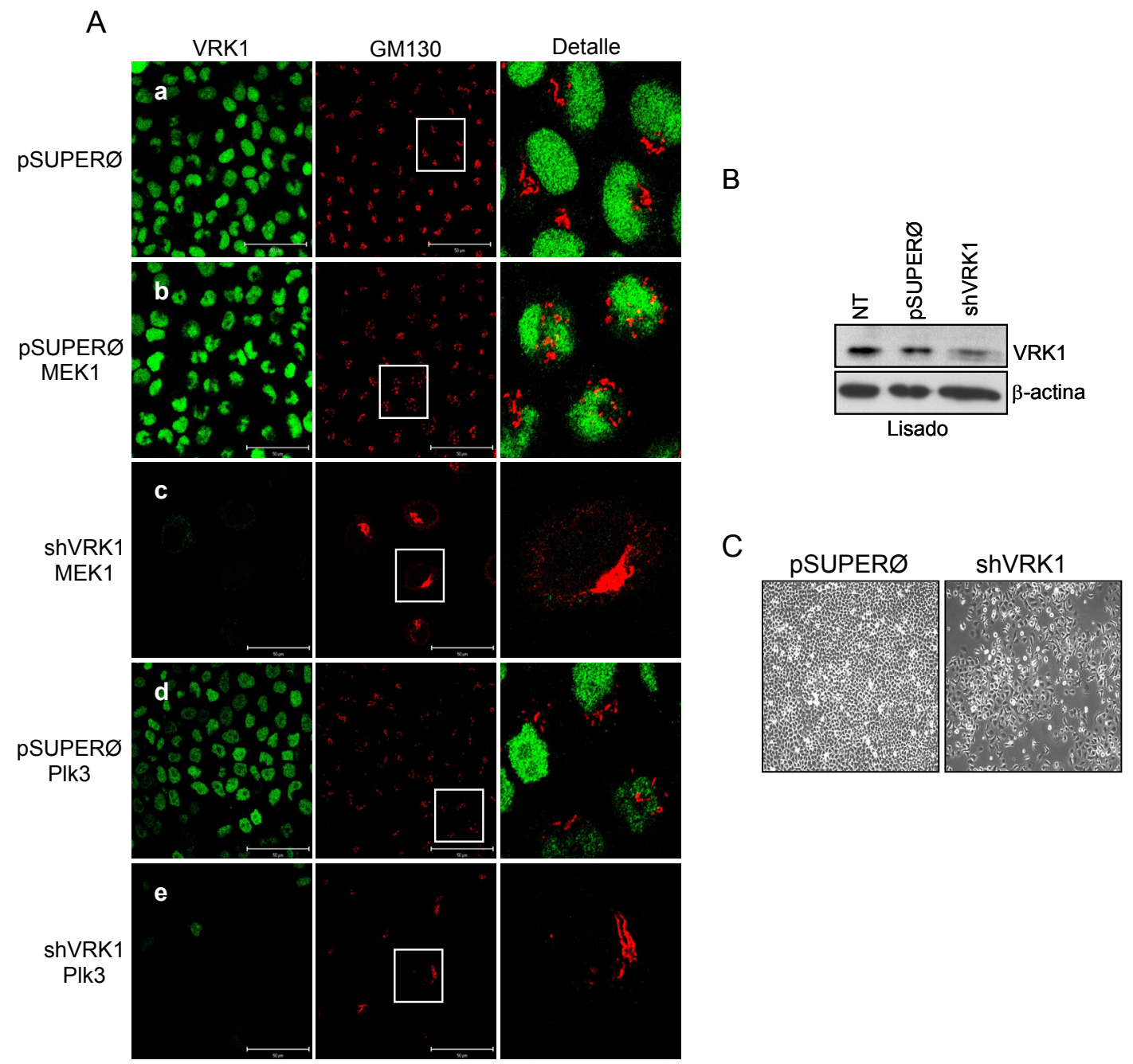

Figura 52. Efecto de la supresión de la expresión de VRK1 mediante short hairpin RNA (shRNA). A) Fenotipo del aparato de Golgi. Se transfectaron células HeLa con $3 \mu \mathrm{g}$ de vector vacío (pSUPERØ) o un vector que codifica para ARN de interferencia específico para VRK1 (shVRK1). 4 días después, se retransfectaron vectores de expresión para las proteínas indicadas en la figura. VRK1 se detectó con un anticuerpo policlonal (VC- verde) y el aparato de Golgi con uno monoclonal (GM130- rojo). La barra indica $50 \mu \mathrm{m}$. B) Inmunoblot de VRK1. Se verificó la eficiencia del ARN de interferencia por inmunoblot. NT- no transfectado. C) Imágenes de células HeLa en cultivo. Se hicieron fotos de células HeLa sometidas a la transfección con shVRK1.

Los resultados obtenidos mediante la transfección del vector que codifica para ARN de interferencia específico para VRK1 fueron los mismos (Figura 52). En este caso, las células HeLa fueron transfectadas con un vector que codificaba para ARN de interferencia para VRK1 (pSUPER-shVRK1) o el correspondiente vector vacío (pSUPERØ). La eficiencia de la depleción por este método de la proteína VRK1 a los 4 días se corroboró por inmunoblot (Figura 52B). Por tanto, después de 4 días, se retransfectaron las células con las proteínas MEK1 o Plk3 y se fijaron 15 horas o 13 horas después, respectivamente. Se observó que el aparato de Golgi, identificado por 
la tinción de la proteína GM130 (rojo) se fragmentaba tanto en células transfectadas con MEK1 como con Plk3 en células con pSUPER $\varnothing$ (Figura 52A, paneles b y d). Sin embargo, en las células deficientes en VRK1 (shVRK1), la fragmentación del aparato de Golgi, inducida por MEK1 y Plk3 era bloqueada (Figura 52A, paneles c y e).

En este ensayo también se hicieron fotos de las células HeLa en cultivo tras el tratamiento con el ARN de interferencia (Figura 52C). El resultado obtenido de los ensayos de depleción de VRK1 indica que la ausencia de la quinasa VRK1 tiene como consecuencia el bloqueo de la señal de fragmentación del aparato de Golgi iniciada por MEK1 o por PIk3, lo que sitúa a VRK1 claramente por debajo de ambas quinasas e indica que es necesaria para la transmisión de la señal.

\subsection{Identificación de un posible sustrato de VRK1 en la ruta de} fragmentación del aparato de Golgi en división celular.

Una vez establecido que la quinasa VRK1 es un nuevo componente en la ruta de señalización MEK1-Plk3 que lleva a la fragmentación del aparato de Golgi en mitosis $y$, teniendo en cuenta que la actividad quinasa de VRK1 es clave en dicho proceso, se procedió a la búsqueda de una posible diana de fosforilación.

En el proceso de fragmentación han sido identificados varios tipos de proteínas como sustratos diana de las distintas quinasas descritas (ver figura 16, pág. 45 de la introducción). Así, por ejemplo, la quinasa ERK2 fosforila a la proteína de la matriz del aparato de Golgi GRASP55, lo que lleva a la rotura de las uniones laterales de las cisternas (Jesch et al., 2001a; Feinstein and Linstedt, 2007) y Cdc2, por ejemplo, fosforila a componentes de la maquinaria de fusión de membranas, como la proteína de la matriz del aparato de Golgi denominada GM130 o el cofactor p47, inhibiendo la fusión de membranas dependiente de las ATPasas NSF y VCP, respectivamente (Lowe et al., 1998; Uchiyama et al., 2003).

En el estudio proteómico que se había llevado a cabo en el laboratorio para la identificación de proteínas asociadas a VRK1, una de ellas fue la ATPasa VCP, de modo que pareció interesante comprobar si, en efecto, existía relación entre VRK1 y VCP.

\subsubsection{Identificación de VCP como proteína candidata a} interaccionar con VRK1 mediante técnicas proteómicas.

Se realizó un ensayo de pulldown de células HEK293T transfectadas con GST-VRK1 y el correspondiente vector vacío pCEFL-GST $\varnothing$ y el precipitado de proteínas se resolvió 
mediante electroforesis bidimensional. Para la separación de la mezcla de proteínas en la primera dimensión, se utilizó el isoelectroenfoque, usando un gradiente de pH 47 no lineal y, en la segunda dimensión, un gel SDS-PAGE al 10\% de acrilamida. Uno de los spots seleccionados $\left(n^{0} 1\right)$ se identificó mediante su huella peptídica como la ATPasa VCP (Figura 53). En la figura $53 \mathrm{~A}$ se muestra el fragmento de gel correspondiente a la región del spot seleccionado que se identificó como VCP (panel derecho). Como se puede comprobar, este spot se detecta en el gel de la muestra de interés (GST-VRK1) y no se observa en el control con el vector vacío (GSTØ).

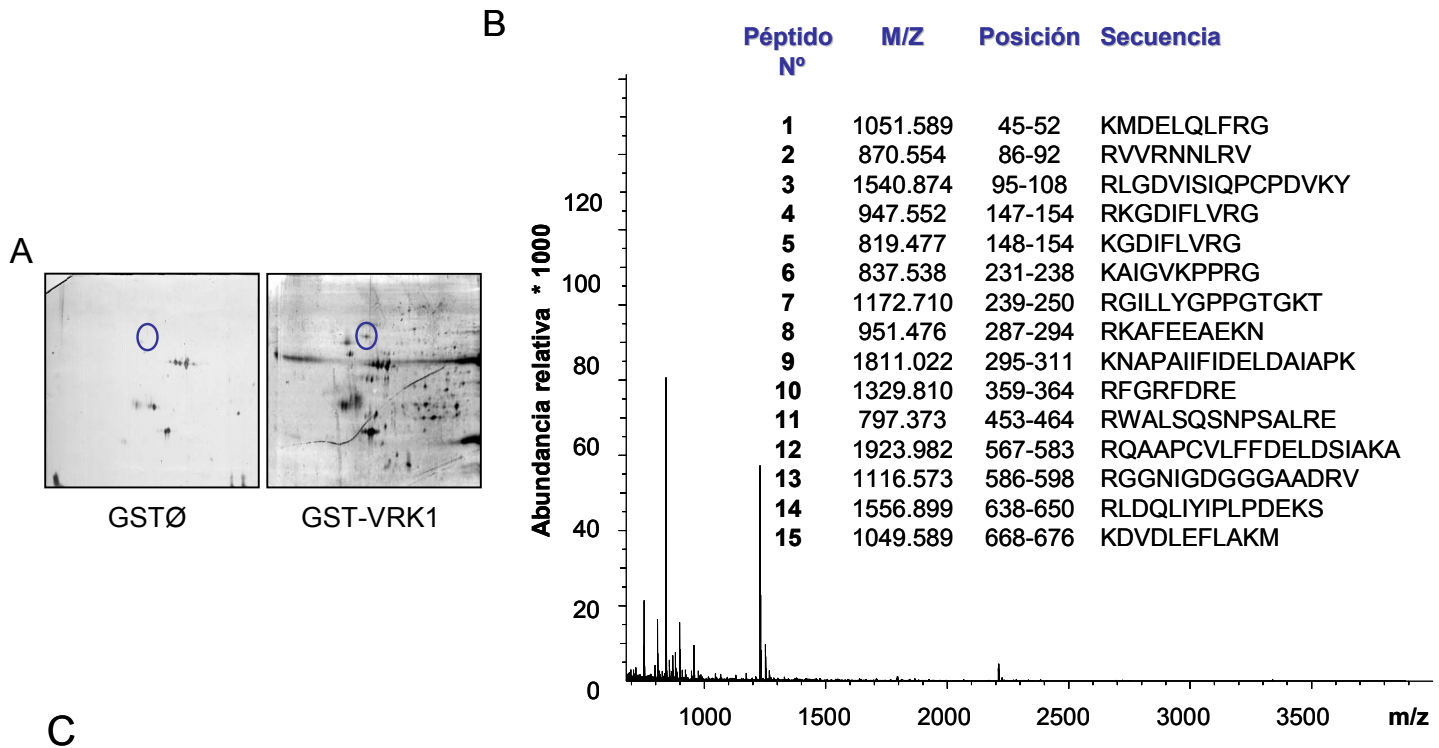

\begin{abstract}
ASGADSKGDD LSTAILKQKN RPNRLIVDEA INEDNSVVSL SQPKMDELQL FRGDTVLLKG KKRREAVCIV LSDDTCSDEK IRMNRVVRNN LRVRLGDVIS IQPCPDVKYG KRIHVLPIDD TVEGITGNLF EVYLKPYFLE AYRPIRKGDI FLVRGGMRAV EFKVVETDPS PYCIVAPDTV IHCEGEPIKR EDEEESLNEV GYDDIGGCRK OLAOIKEMVE LPLRHPALFK AIGVKPPRGI LLYGPPGTGK TLIARAVANE TGAFFFLING PEIMSKLAGE SESNLRKAFE EAEKNAPAII FIDELDAIAP KREKTHGEVE RRIVSQLLTL MDGLKQRAHV IVMAATNRPN SIDPALRRFG REDREVDIGI PDATGRLEIL QIHTKNMKLA DDVDLEQVAN ETHGHVGADL AALCSEAALQ AIRKKMDLID LEDETIDAEV MNSLAVTMDD FRWALSOSNP SALRETVVEV PQVTWEDIGG LEDVKRELQE LVQYPVEHPD KFLKFGMTPS KGVLFYGPPG CGKTLLAKAI ANECQANFIS IKGPELLTMW FGESEANVRE IFDKAROAAP CVLFFDELDS IAKARGGNIG DGGGAADRVI NQILTEMDGM STKKNVFIIG ATNRPDIIDP AILRPGRLDQ LIYIPLPDEK SRVAILKANL RKSPVAKDVD LEFLAKMTNG FSGADLTEIC QRACKLAIRE SIESEIRRER ERQTNPSAME VEEDDPVPEI RRDHFEEAMR FARRSVSDND IRKYEMFAQT LQQSRGFGSF RFPSGNQGGA GPSQGSGGGT GGSVYTEDND DDLYG
\end{abstract}

Figura 53. Identificación de VCP mediante técnicas proteómicas. A) Pulldown de las proteínas asociadas a VRK1. Se transfectaron células HEK293T con $8 \mu \mathrm{g}$ de pCEFL-GST-VRK1 y $2 \mu \mathrm{g}$ de pCEFL-GST $\varnothing$ como control. 48 horas después, se precipitaron las proteínas asociadas a VRK1 con la resina Glutathion Sepharose. Este precipitado se resolvió por electroforesis bidimensional. El spot seleccionado en azul fue más tarde identificado como VCP. B) Espectro de masas y péptidos asignados del spot seleccionado. Se muestra el espectro de masas obtenido de VCP y se indica el valor de la masa experimental $(\mathrm{m} / \mathrm{z})$, la secuencia de aminoácidos y la posición de los péptidos. C) Cobertura de la secuencia de VCP. Se indica la posición exacta de los péptidos obtenidos en la secuencia de aminoácidos de VCP (subrayado y en azul).

El spot fue digerido con tripsina, lo que generó un conjunto de péptidos (huella peptídica) que se analizó mediante un espectrómetro MALDI-TOF, generando un 
espectro de valores de masa experimentales ( $\mathrm{m} / \mathrm{z}$ ) (Figura 53B). De los valores obtenidos, 25 fueron utilizados para la identificación de la proteína mediante el buscador MASCOT (Perkins et al., 1999) y solamente 15 fueron asignados a valores de masa de péptidos teóricos de VCP. En la figura 53B se muestra el conjunto de péptidos que sirvieron para la identificación con su secuencia y posición. Los péptidos asignados corresponden a un $18 \%$ de la secuencia de VCP (Figura 53C), lo que determina un score de 133 que, según los parámetros establecidos, es estadísticamente significativo ya que es superior a 54. De modo que, en esta ocasión, la identificación de VCP como proteína candidata a interaccionar con VRK1 es una identificación de alta confianza.

Teniendo en cuenta que la identificación de VCP es estadísticamente significativa y dadas sus funciones asociadas a la dinámica del aparato de Golgi en mitosis, se decidió continuar con el estudio y se clonó la proteína VCP en diferentes vectores de expresión para bacterias y para mamíferos con distintos epítopos.

\subsubsection{Validación de la interacción VRK1-VCP.}

Antes de caracterizar la posible relación de VCP con VRK1 en una función in vivo, era necesario validar la interacción mediante diversas técnicas y experimentos, de modo que la identificación que se había obtenido por métodos proteómicos se confirmara.

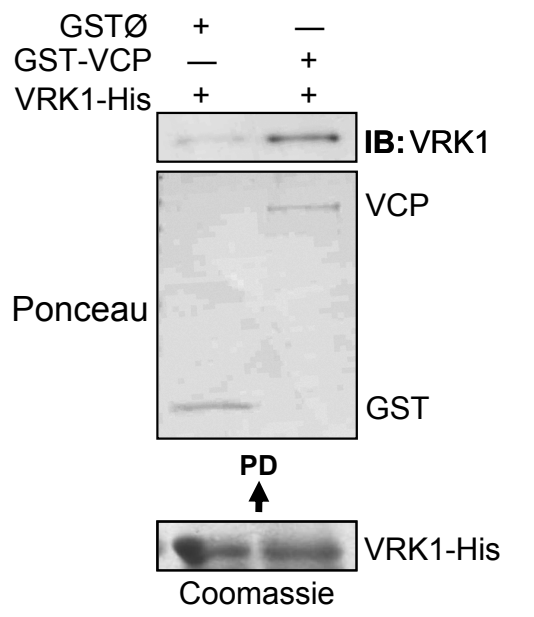

Figura 54. La quinasa VRK1 interacciona con VCP in vitro. Se llevó a cabo un ensayo de interacción in vitro utilizando pGEX-4T1-GST-VCP y pET23-VRK1-His. GST-VCP se precipitó añadiendo la resina Glutathion Sepharose a la mezcla. Se detectó la presencia de VRK1-His en los precipitados por inmunoblot con un anticuerpo para VRK1 (1F6) y la proteína VCP precipitada se detectó por tinción Ponceau. Como control del ensayo se usó el vector vacío pGEX-4T1-GSTØ.

Para ello, lo primero fue determinar la interacción de ambas proteínas in vitro utilizando las dos proteínas purificadas expresadas en E. coli con dos epítopos distintos. La proteína VCP se usó fusionada al epítopo GST y VRK1 fusionada al epítopo 6xHis (VRK1-His). La mezcla de proteínas se incubó en presencia de la resina Glutathion Sepharose que precipitó GST-VCP y GST $\varnothing$ como control del ensayo. Como 
se aprecia en el inmunoblot (Figura 54), la quinasa VRK1 es detectada en el precipitado de VCP. Por lo tanto, se puede concluir que VRK1 y VCP interaccionan directamente.

Para demostrar firmemente la interacción entre VRK1 y VCP in vivo se realizaron varias aproximaciones. En primer lugar, se realizaron ensayos de pulldown en los que construcciones de las proteínas VCP o VRK1 fusionadas a GST eran transfectadas en células HEK293T y se detectaba si la proteína endógena VRK1 o VCP se precipitaba asociada a la proteína transfectada (Figura 55).

A

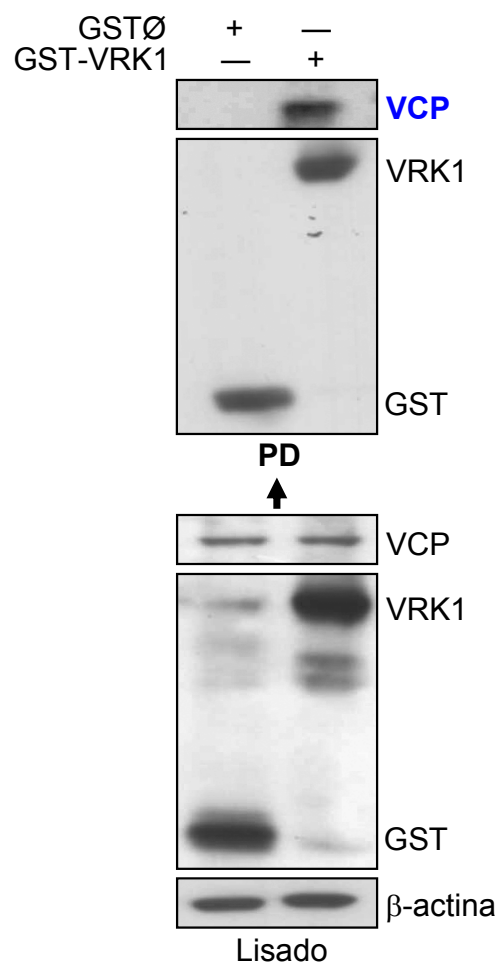

B

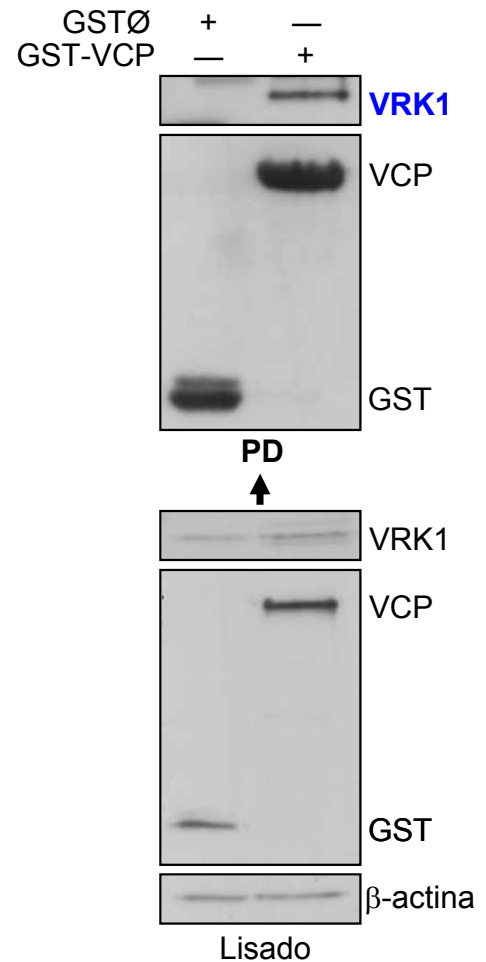

Figura 55. Pulldowns recíprocos. A) Se transfectaron células HEK293T con $2 \mu \mathrm{g}$ de pCEFLGST $\varnothing$ y $5 \mu \mathrm{g}$ de pCEFL-GST-VRK1. Se detectó la proteína VCP endógena con un anticuerpo policlonal específico y las proteínas precipitadas con un anticuerpo monoclonal anti-GST. B) Se transfectaron células HEK293T con $2 \mu \mathrm{g}$ de pCEFL-GSTØ y $5 \mu \mathrm{g}$ de pCEFL-GST-VCP. Se detectó la proteína VRK1 endógena con un anticuerpo policlonal (VC) y las proteínas precipitadas con un anticuerpo monoclonal anti-GST.

Tanto en el pulldown en el que se precipitó GST-VRK1 (Figura 55A) como en el que se precipitó GST-VCP (Figura 55B), se detectaron las proteínas endógenas VCP o VRK1, respectivamente (Figura 55, en azul). Sin embargo, estas no se detectaron en el control negativo del ensayo realizado con el correspondiente vector vacío pCEFLGST Ø. 
A continuación, se llevó a cabo un ensayo de pulldown para determinar si la interacción VRK1-VCP era más estable con la quinasa VRK1 inactiva. Para ello, se transfectaron células HEK293T con las construcciones de la proteína VRK1 silvestre (GST-VRK1), la proteína VRK1 sin actividad quinasa (GST-VRK $1^{\mathrm{K} 179 \mathrm{E}}$ ), la ATPasa VCP (AU5-VCP) y el vector vacío correspondiente (GSTØ) (Figura 56).

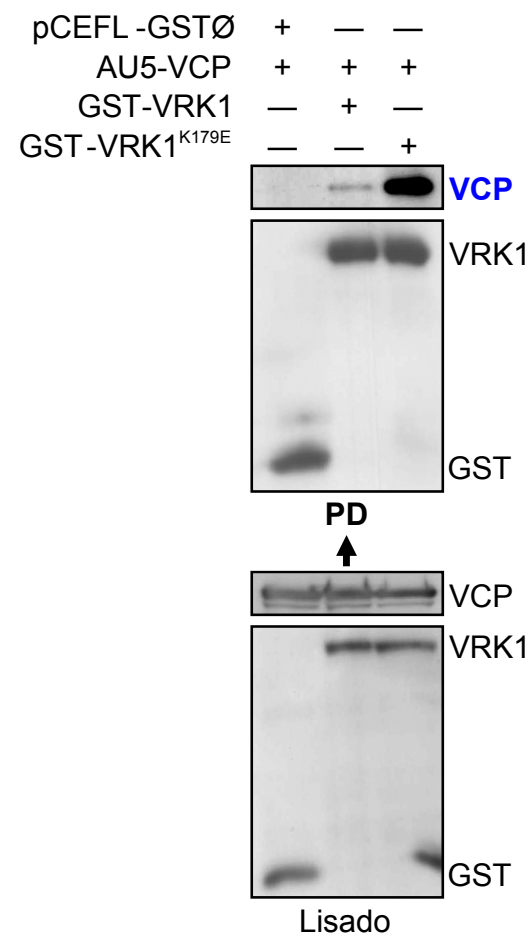

Figura 56. La interacción es más estable con la quinasa VRK1 inactiva. Se transfectaron células HEK293T con los vectores pCEFL-AU5VCP $(5 \mu \mathrm{g})$, pCEFL-GST-VRK1 $(4 \mu \mathrm{g})$, pCEFLGST-VRK1 ${ }^{\text {K179E }}(8 \mu \mathrm{g})$ y el vector vacío pCEFLGST $\varnothing(2 \mu \mathrm{g})$. La proteína VCP precipitada se detectó con un anticuerpo monoclonal para su epítopo (AU5).

Los extractos celulares se incubaron con la resina Glutathion Sepharose y, tras los lavados correspondientes, se realizó un inmunoblot para detectar la proteína VCP precipitada (Figura 56, en azul). La ATPasa interacciona tanto con VRK1 silvestre como con VRK1 sin actividad quinasa. Sin embargo, la interacción es más estable en presencia de la quinasa sin actividad, fenómeno que es habitual en interacciones con quinasas, ya que al carecer de actividad, retienen la interacción, lo que sugiere que VCP puede ser sustrato de VRK1.

Por último, se hizo un ensayo de pulldown para determinar la región de interacción de VCP en la quinasa VRK1 (Figura 57A). En este ensayo se utilizaron dos construcciones de VRK1: la proteína VRK1 completa (GST-VRK1, aa 1-396) y la proteína VRK1 carboxilo (GST-VRK1-C, aa 267-396), que comprende toda la región carboxilo de la proteína y algunos aminoácidos del dominio quinasa. Tras analizar la presencia de la proteína VCP en el precipitado resultante con anticuerpos específicos para el epítopo AU5, se pudo observar interacción de la ATPasa VCP tanto con la 
quinasa VRK1 completa como la quinasa VRK1 carboxilo, pero no con el control del vector vacío (GSTØ). Por lo tanto, se concluyó que la zona de interacción de la ATPasa VCP con la quinasa VRK1 abarca la región carboxilo de esta (aa 267-396) (Figura 57B).

A

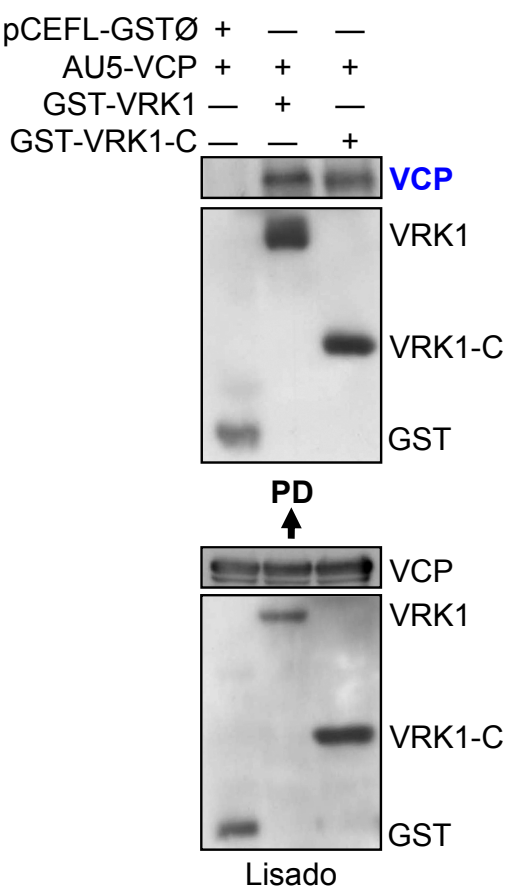

B

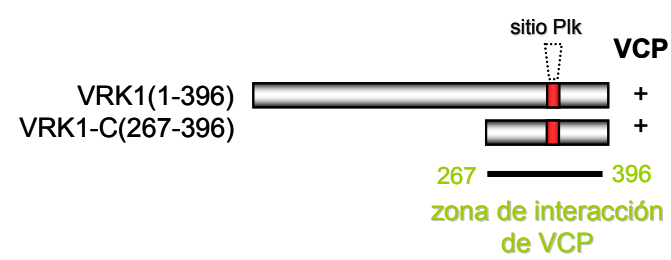

Figura 57. VCP interacciona con la región carboxilo de VRK1. A) Se transfectaron células HEK293T con los vectores PCEFL-AU5VCP $(5 \mu \mathrm{g})$, pCEFL-GST-VRK1 $(5 \mu \mathrm{g})$, pCEFLGST-VRK1-C $(3 \mu \mathrm{g})$ y vector vacío pCEFLGSTØ $(2 \mu \mathrm{g})$. Las proteínas fueron precipitadas con la resina Glutathion Sepharose y detectadas con anticuerpos frente a los epítopos AU5 y GST. B) Zona de interacción de VCP en VRK1.

\subsubsection{Análisis de la función de la interacción VRK1-VCP.}

Una vez confirmado mediante diferentes ensayos que, en efecto, la quinasa VRK1 y la ATPasa VCP interaccionan in vitro e in vivo, el siguiente paso fue el análisis de la posible función asociada a estas dos proteínas.

\section{a) VRK1 no fosforila a VCP en un ensayo quinasa in vitro.}

Una posible función de la interacción VRK1-VCP podría ser la formación de un complejo enzima-sustrato. De hecho, VCP sería una candidata idónea como posible sustrato diana en el proceso de fragmentación del aparato de Golgi en mitosis. Además, se han descrito diversas quinasas que fosforilan a la ATPasa VCP como, por ejemplo, ATM, ATR, DNA-PK y Akt (Klein et al., 2005; Livingstone et al., 2005; Vandermoere et al., 2006).

Para ello, se realizó un ensayo quinasa in vitro en presencia de $\left[{ }^{32} \gamma-P\right]$ ATP y proteínas purificadas fusionadas a GST. Se incluyeron la proteína VRK1 silvestre (GST-VRK1) y un mutante de VRK1 sin actividad quinasa (GST-VRK1 ${ }^{\mathrm{K} 179 \mathrm{E}}$ ). En la 
autorradiografía del experimento (Figura $58,{ }^{32} \mathrm{P}$ ), solamente se detecta la señal de autofosforilación de la quinasa VRK1 silvestre. Sin embargo, se puede apreciar cómo el nivel de autofosforilación de VRK1 sola (carril 1) es mayor que el de VRK1 en presencia de VCP (carril 3), mientras que los niveles de proteína, detectados mediante tinción con Coomassie, son prácticamente iguales. Se puede concluir, por un lado, que la ATPasa VCP no parece ser sustrato de VRK1 en un ensayo quinasa clásico y, por otro, que en presencia de VCP la actividad de la quinasa VRK1 medida a través de su autofosforilación es menor.

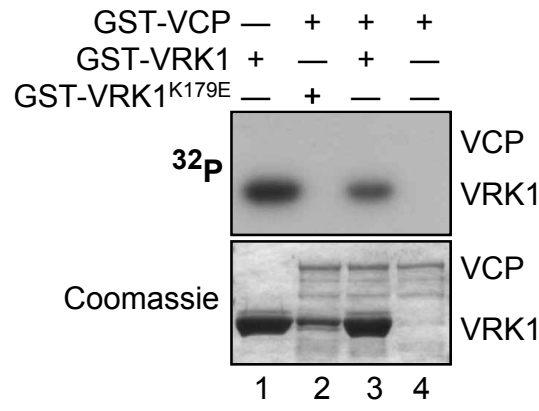

b) Efecto de VCP sobre la actividad de VRK1 in vitro.

El efecto observado en el ensayo anterior (Figura 58), llevó a plantear dos opciones: una posible regulación de la actividad de VRK1 o una posible competencia por el ATP. La primera opción se planteó debido a los antecedentes relacionados con la GTPasa nuclear Ran, que inhibe la actividad de VRK1 in vitro a través de la interacción directa con ella (Sanz-Garcia et al., 2008). Por otro lado, esta inhibición de VRK1 podría ser consecuencia de una competencia por el ATP, ya que ambas proteínas, VRK1 y VCP, unen ATP para llevar a cabo sus funciones, si bien el número de moléculas que une VCP es mayor ya que funciona como hexámero y cada monómero tiene dos dominios ATPasa (Song et al., 2003; Wang et al., 2003a).

Por ello, se llevaron a cabo dos ensayos relacionados con estas dos posibilidades. En un primer experimento, se realizó un ensayo quinasa in vitro en presencia de $\left[{ }^{32} \gamma\right.$-P] ATP y las proteínas purificadas VRK1, VCP y p53 fusionadas a GST (Figura 59A). La proteína p53 se utilizó como control del ensayo ya que es un sustrato bien establecido para VRK1 (Lopez-Borges and Lazo, 2000; Vega et al., 2004). En este ensayo, se quiso comprobar si el posible efecto de la inhibición de la actividad de VRK1 era dependiente de la dosis de VCP. Se utilizaron dosis crecientes de VRK1 con p53 y, a la dosis más alta de VRK1, se añadieron dos cantidades 
distintas de VCP. Como se puede ver en la figura 59A, la autofosforilación de VRK1 y la fosforilación de p53 son dependientes de la cantidad de VRK1. Además, la adición de cantidades crecientes de VCP produce una inhibición de la autofosforilación de VRK1 dependiente de la dosis de VCP. A la vista de estos resultados, se podría pensar que la ATPasa está ejerciendo una regulación negativa de la actividad de VRK1 mediada por una interacción proteína-proteína.

A

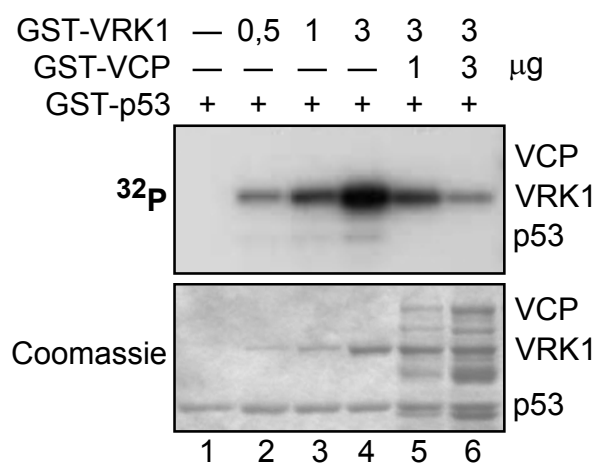

B

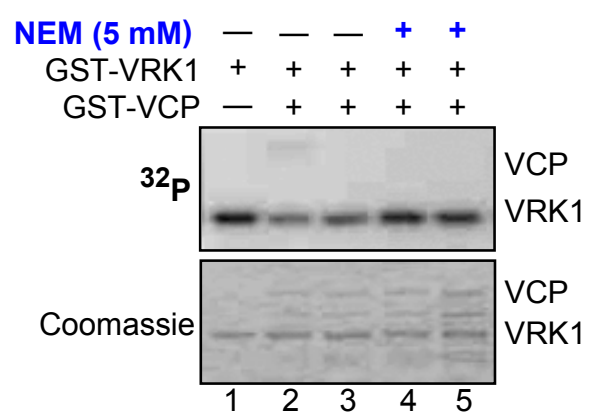

Figura 59. A) Efecto dosis de la ATPasa VCP sobre la actividad de VRK1 in vitro. Se llevó a cabo un ensayo quinasa in vitro en presencia de $\left[{ }^{32} \gamma-P\right]$ ATP con cantidades crecientes de GSTVRK1 y GST-VCP en las cantidades y combinaciones indicadas en la figura. Como control positivo se usó GST-p53 (aa 1-85). Se detectaron la autofosforilación de VRK1 y la fosforilación de p53 $\left({ }^{32} \mathrm{P}\right)$. Los niveles de proteína se muestran en el Coomassie. B) El tratamiento con NEM evita el efecto de VCP sobre la actividad de VRK1 in vitro. Se llevó a cabo un ensayo quinasa in vitro en presencia de $\left[^{32} \gamma\right.$-P] ATP con VCP pretratada o no con NEM $\left(37^{\circ} \mathrm{C}, 15\right.$ minutos) y GST-VRK1. Se muestra la autofosforilación de VRK1 $\left({ }^{32} \mathrm{P}\right)$ y los niveles de proteína en el Coomassie.

Para descartar esta posibilidad se pueden realizar varias aproximaciones. La más sencilla sería la utilización de un mutante de VCP incapaz de unir ATP. Sin embargo, no se disponía de ninguno así que se decidió usar un inhibidor denominado NEM ( $\mathrm{N}$-Etilmaleimida) que es un agente alquilante de cisteínas que bloquea los grupos tioles libres, de modo que no permite la unión de ATP. Se ha demostrado firmemente que este agente inhibe la actividad de la ATPasa VCP en un $80 \%$ a una concentración de $5 \mathrm{mM}$ (Song et al., 2003). Con algunas proteínas se ha observado que el efecto de inactivación producido por NEM es consecuencia de la desnaturalización de las proteínas y que esta desnaturalización es la que inhibe su actividad. En el caso de VCP, el tratamiento con NEM no provoca la desnaturalización de la proteína y esta sigue manteniendo su estructura de hexámero lo que implica que es perfectamente funcional (Song et al., 2003). Así, se incubó la proteína GST-VCP con $5 \mathrm{mM}$ del inhibidor NEM y, a continuación, esta VCP se utilizó en un ensayo 
quinasa in vitro en presencia de VRK1. Cada punto del ensayo se realizó por duplicado y, como se puede ver en la figura 59B, la autofosforilación de VRK1 en presencia de la ATPasa VCP pretratada con NEM (carriles 4 y 5 ) es similar a la observada con la proteína VRK1 sola (carril 1). De modo que se puede concluir que el efecto de inhibición observado en los experimentos anteriores es la consecuencia de la competencia por el ATP y no la regulación negativa de la actividad quinasa de VRK1.

\section{c) El cofactor p47 tampoco es sustrato de VRK1 in vitro.}

De los cofactores descritos para VCP, solamente p47 ha sido directamente relacionado con la fragmentación del aparato de Golgi al inicio de la mitosis, ya que es fosforilado por la quinasa Cdc2 en la serina 140, lo que lleva a la inhibición de los procesos de fusión dependientes de VCP y, por tanto, a la fragmentación de las cisternas del aparato de Golgi (Kondo et al., 1997; Uchiyama et al., 2003). Por ello, se decidió hacer un ensayo quinasa in vitro utilizando la ATPasa VCP, el cofactor p47 y la quinasa VRK1 (Figura 60).

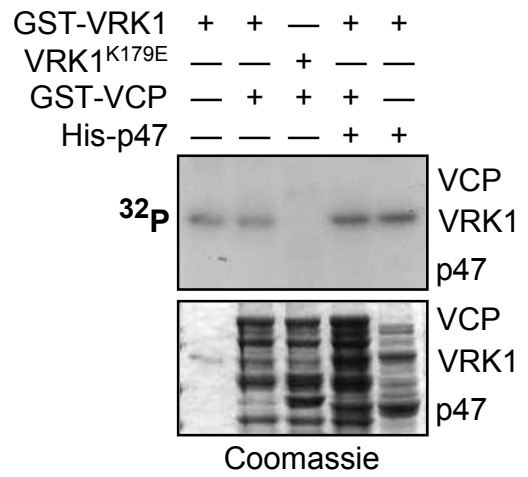

Se pensó que quizás la quinasa VRK1 interaccionaba con VCP pero que su sustrato diana pudiera ser el cofactor p47 o que quizás fuera necesaria la formación del complejo VCP-p47 para que VRK1 fosforilara a la ATPasa VCP. Como se aprecia en la figura 60, en ningún caso se detecta fosforilación por VRK1 de VCP, p47 o el complejo VCP-p47 in vitro.

\section{d) VRK1 precipitada de células es capaz de fosforilar a VCP.}

A la vista de los resultados obtenidos mediante ensayos quinasas in vitro clásicos, se decidió realizar un último tipo de ensayo quinasa para concluir definitivamente si, en 
efecto, la quinasa VRK1 no fosforila a VCP. Con este objetivo, se llevaron a cabo dos aproximaciones distintas. En un primer ensayo, se transfectaron células HEK293T con las proteínas VRK1 silvestre y VRK1 sin actividad quinasa con el epítopo HA. A continuación, se inmunoprecipitaron con un anticuerpo monoclonal frente al epítopo HA y se utilizaron en un ensayo quinasa in vitro en presencia de $\left[{ }^{32} \gamma\right.$-P] ATP y las proteínas VCP y p47 purificadas (Figura 61A). Como control del ensayo se realizó una inmunoprecipitación inespecífica con un anticuerpo anti-FLAG y, en uno de los puntos, la quinasa VRK1 silvestre se incubó con fosfatasa alcalina (CIAP).

B

A
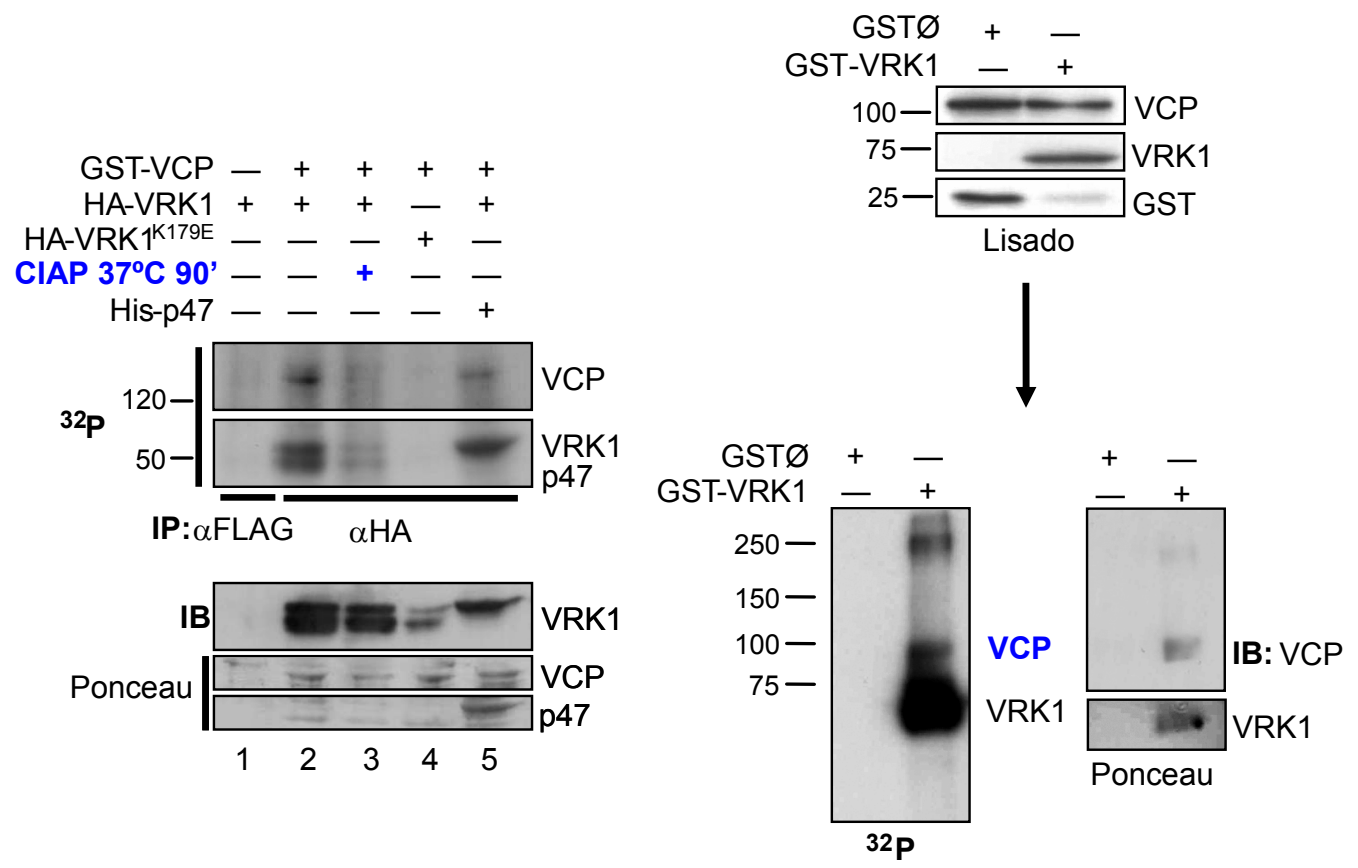

Figura 61. A) VRK1 silvestre pero no el mutante inactivo VRK1 ${ }^{\mathrm{K} 179 \mathrm{E}}$ precipitado de células fosforila a VCP. Se transfectaron células HEK293T con pCEFL-HA-VRK1 $(4 \mu \mathrm{g})$ y pCEFL-HAVRK $1^{\mathrm{K} 179 \mathrm{E}}(12 \mu \mathrm{g})$. A continuación, se inmunoprecipitaron con un anticuerpo monoclonal frente a HA y se realizó un ensayo quinasa in vitro en presencia de $\left[{ }^{32} \gamma\right.$-P] ATP con proteínas purificadas GST-VCP y His-p47. Se realizó una inmunoprecipitación inespecífica con un anticuerpo anti-FLAG. Uno de los puntos se trató con fosfatasa alcalina (CIAP) y, en todos los casos, VCP se trató con $\operatorname{NEM}\left(5 \mathrm{mM}\right.$ a $37^{\circ} \mathrm{C}$ durante 15 minutos). Se muestra la autofosforilación de VRK1 y la fosforilación de VCP $\left.{ }^{32} \mathrm{P}\right)$. Los niveles de proteína se detectaron por inmunoblot o Ponceau. B) Pulldown de VRK1 y ensayo quinasa de las proteínas asociadas. Se transfectaron células HEK293T con pCEFL-GST-VRK1 $(5 \mu \mathrm{g})$ y vector vacío [pCEFL-GST $\varnothing(2 \mu \mathrm{g})$ ]. Se realizó un pulldown de estos extractos $(5 \mathrm{mg})$ con la resina Glutathion Sepharose. A este precipitado se le realizó un ensayo quinasa in vitro y se examinó la radiactividad incorporada $\left({ }^{32} \mathrm{P}\right)$. Se corroboró la presencia de VCP endógena por inmunoblot con un anticuerpo policlonal específico. La proteína VRK1 precipitada se detectó por tinción con Ponceau.

La autofosforilación de la quinasa VRK1 silvestre se detecta en la autorradiografía (Figura $61 \mathrm{~A},{ }^{32} \mathrm{P}$, carriles 2 y 5 ) y, en estos mismos puntos, se observa 
la fosforilación de la ATPasa VCP independiente de la presencia o no del cofactor p47. La quinasa VRK1 se caracteriza por su fuerte autofosforilación in vitro (Lopez-Borges and Lazo, 2000; Barcia et al., 2002), de modo que se decidió comprobar si VRK1 requería fosforilaciones para su actividad. Para ello, la proteína VRK1 silvestre inmunoprecipitada de células se trató con la fosfatasa alcalina (CIAP) y se determinó que tras el tratamiento con la fosfatasa, se reduce su nivel de autofosforilación y la fosforilación sobre VCP (carril 3). Además, se inmunoprecipitó la quinasa VRK1 inactiva $\left(\mathrm{VRK} 1^{\mathrm{K} 179 \mathrm{E}}\right)$ y se comprobó que en ese caso tampoco se detectaba fosforilación de VCP (carril 4).

Por tanto, este resultado indica que la ATPasa VCP es sustrato de la quinasa VRK1 inmunoprecipitada de células y que esta fosforilación no ocurre en presencia de la quinasa VRK1 inactiva o la quinasa VRK1 desfosforilada con la fosfatasa alcalina, lo que sugiere que VRK1 debe estar fosforilada para ser activa. Además, el hecho de que en presencia de la quinasa VRK1 inactiva no tenga lugar la fosforilación de VCP indica que no es ninguna quinasa asociada a la proteína VRK1 precipitada de células la que está llevando a cabo dicha fosforilación. Además, ni VRK1 fosforila al cofactor p47, ni la presencia de este, afecta a la fosforilación de VCP.

El segundo ensayo consistió en la transfección de pCEFL-GST-VRK1 y el correspondiente vector vacío pCEFL-GST $\varnothing$ en células HEK293T. Se llevó a cabo un ensayo de pulldown a partir de gran cantidad de extracto celular (5 mg) y, a continuación, se realizó un ensayo quinasa in vitro de la proteína VRK1 precipitada y las proteínas asociadas a esta por interacción. En la autorradiografía $\left({ }^{32} \mathrm{P}\right)$ de la figura 61B se aprecia la señal de autofosforilación de VRK1 y otras señales a distintos pesos moleculares. De hecho, se detecta una señal relativamente fuerte a la altura de 100 $\mathrm{KDa}$, que es el peso molecular aproximado de la ATPasa VCP. Para comprobar si esa señal radiactiva podría corresponder a VCP, se realizó un inmunoblot de esa membrana con un anticuerpo específico para VCP y se determinó que, en efecto, la señal radiactiva observada en torno a $100 \mathrm{KDa}$ correspondía a VCP. La cantidad de VRK1 precipitada se detectó mediante tinción con Ponceau de la membrana.

De estos ensayos se puede concluir que VCP es sustrato de VRK1, aunque esta fosforilación no se logra detectar en un ensayo quinasa in vitro con proteínas purificadas. Sin embargo, utilizando la quinasa VRK1 inmunoprecipitada de células se logra detectar la fosforilación sobre la ATPasa VCP purificada (Figura 61A) y también sobre la ATPasa VCP endógena inmunoprecipitada en asociación con VRK1 (Figura 61B). 


\section{e) La depleción de VRK1 evita la fosforilación de VCP en mitosis.}

A continuación, se quiso analizar de un modo preliminar si, efectivamente, la relación establecida entre VRK1 y VCP tenía algún tipo de implicación en el proceso biológico de la fragmentación del aparato de Golgi al inicio de mitosis estudiado en la presente tesis. Hasta el momento, los resultados apuntan a que VRK1 se activa en mitosis y que dicha activación es debida a la fosforilación por Plk3 downstream de MEK1. Desde luego, la ATPasa VCP es una candidata idónea en dicho proceso ya que la fusión de membranas debe inhibirse para que se produzca la fragmentación de las cisternas en vesículas y túbulos y se puedan repartir entre las dos células hijas (Shorter and Warren, 2002). Además, el cofactor p47 implicado en este proceso es fosforilado por la quinasa mitótica Cdc2 en mitosis (Uchiyama et al., 2003). Así, se puede asumir que al igual que el cofactor p47 se fosforila en mitosis, quizás también sea necesaria la fosforilación de VCP para la inhibición de la fusión de membranas.

Bajo esta hipótesis se llevó a cabo un experimento en el que se incubó la ATPasa VCP purificada de bacterias (pGEX-4T1-GST-VCP) con extracto mitótico (Noc.) o con extracto de células asincrónicas (Asin.) HEK293T previo tratamiento con ARN de interferencia control (siControl) o específico para VRK1 (siVRK1) (Figura 62).

A
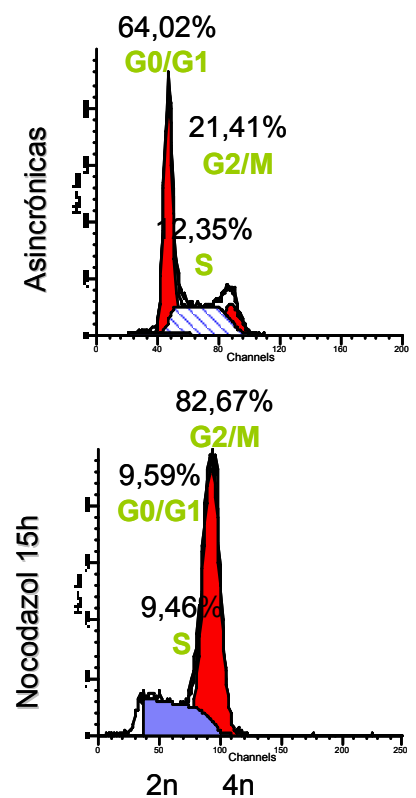

B
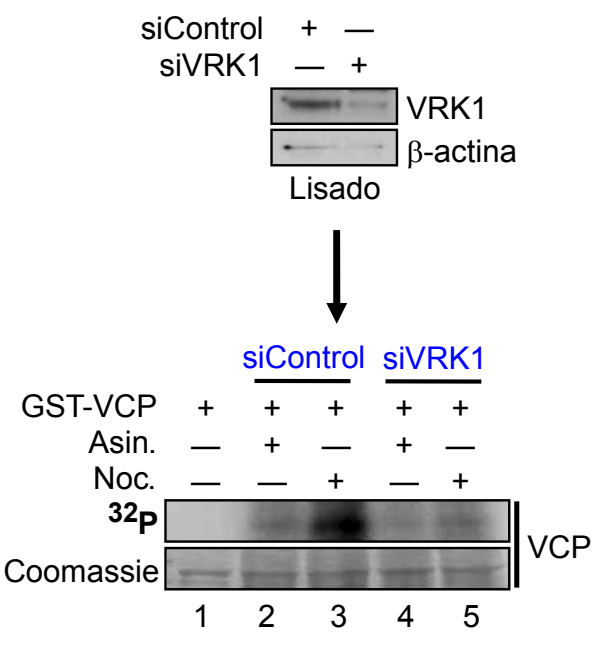

Figura 62. La depleción de VRK1 evita la fosforilación de VCP en mitosis. A) Perfil de ciclo de células HEK293T en cultivo asincrónico y células tratadas con nocodazol (83 nM, 15h). B) Células HEK293T fueron transfectadas con siControl o siVRK1. 48h después, fueron tratadas o no con nocodazol para pararlas en mitosis como en el apartado A. En el lisado celular se detectó la depleción de VRK1 (1F6). A continuación, se incubó la proteína VCP purificada con $1 \mathrm{mg}$ de cada extracto celular de HEK293T y se realizó un ensayo quinasa in vitro en presencia de ATP radiactivo. La fosforilación de VCP se detectó en la autorradiografía $\left({ }^{32} \mathrm{P}\right)$ y los niveles de proteína por tinción Coomassie. Asin.- asincrónicas; Noc. -nocodazol. 
Una vez comprobado que las células se habían parado en mitosis tras el tratamiento con nocodazol (Figura 62A), se determinó la bajada en el nivel de proteína de VRK1 mediante inmunoblot (Figura 62B, lisado). A continuación, se llevó a cabo un ensayo quinasa in vitro con los distintos tipos de extracto de células HEK293T. Como se aprecia en la autorradiografía (Figura $62 \mathrm{~B},{ }^{32} \mathrm{P}$ ), la ATPasa VCP se fosforila tanto tras la incubación con extracto asincrónico (Asin.) como con extracto de células mitóticas (Noc.). El nivel de fosforilación de VCP es máximo tras su incubación con células en mitosis en presencia del ARN de interferencia control (carril 3). Sin embargo, no se detecta esta fosforilación tras incubarse con extracto de células HEK293T deplecionadas de VRK1 y en mitosis (carril 5). También se observa una disminución en el grado de fosforilación de VCP tras la incubación con extracto asincrónico deplecionado de VRK1 (carril 4). Como control del ensayo se incubó VCP purificada con el tampón de lisis utilizado para lisar las células del ensayo (carril 1). Por tanto, la ATPasa VCP se fosforila tanto en interfase como en mitosis, si bien su nivel de fosforilación es máximo en mitosis coincidiendo con la activación de la quinasa VRK1. Teniendo en cuenta que al deplecionar VRK1 dicha fosforilación se reduce drásticamente, cabe pensar que la quinasa VRK1 es en parte responsable de de esa fosforilación.

Se ha demostrado que la ATPasa VCP y la quinasa VRK1 interaccionan in vitro e in vivo. Además, VCP es sustrato de la quinasa VRK1 y parece que es responsable de la fosforilación de esta en mitosis. Futuros experimentos tratarán de resolver si esta primera conexión establecida entre VRK1 y VCP está o no directamente relacionada con el proceso de fragmentación del aparato de Golgi en mitosis en el que VRK1 participa. 
Discusión 



\section{Localización subcelular de VRK1.}

La quinasa VRK1 se caracteriza por una expresión ubicua en todos los tejidos y líneas celulares analizadas (Nezu et al., 1997) y los datos relacionados con su localización subcelular la describen esencialmente nuclear, excluida o no del nucleolo (Vega et al., 2004). Con respecto a su localización en tejidos, lo que se había descrito hasta el momento era una localización claramente nuclear identificada con el anticuerpo policlonal VC (Santos et al., 2006; Valbuena et al., 2007b). De hecho, la quinasa VRK1 contiene en su extremo carboxilo terminal una secuencia de localización nuclear (NLSKKRKK, aminoácidos 356-360) (Zelko et al., 1998; Lopez-Borges and Lazo, 2000).

Con objeto de analizar en más detalle la localización subcelular de esta quinasa, se llevaron a cabo inmunohistoquímicas de tejidos normales e inmunofluorescencias de distintas líneas celulares utilizando dos anticuerpos específicos para VRK1, uno monoclonal (1F6) y otro policlonal (VC). Los resultados obtenidos muestran distintas subpoblaciones de VRK1, identificando en la mayoría de los casos el anticuerpo VC una subpoblación nuclear y el anticuerpo 1F6 una subpoblación citoplasmática. Además, el reconocimiento de las distintas subpoblaciones es tal, que sus señales ni siquiera se solapan en aquellos casos en los que ambos anticuerpos detectan subpoblaciones en el citoplasma.

La presencia de una posible secuencia de exportación nuclear en la región carboxilo terminal de VRK1 (aminoácidos 298-310) explicaría cómo se regula la salida al citoplasma de una proteína esencialmente nuclear y con una secuencia de localización nuclear bien definida.

Aparte de las subpoblaciones citoplasmática y nuclear, el anticuerpo 1F6 determina una nueva subpoblación con aspecto de agregado localizada en la zona perinuclear de las células. Tras el análisis por inmunofluorescencia, se concluyó que ese agregado se correspondía con membranas del aparato de Golgi. Es decir, la subpoblación de VRK1 identificada con el anticuerpo 1F6 colocaliza perfectamente con la proteína estructural Giantina usada como marcador de cis/medial-Golgi (Linstedt and Hauri, 1993; Linstedt et al., 1995) y no con la proteína Calreticulina usada como marcador de retículo endoplasmático (Michalak et al., 1992). Además, ensayos específicos de fraccionamiento subcelular confirmaron la existencia de una población de VRK1 estrechamente asociada con las membranas del aparato de Golgi.

Para llevar a cabo un análisis más exhaustivo de la subpoblación de la quinasa VRK1 asociada al aparato de Golgi, se estudió la localización de esta subpoblación en mitosis, ya que en esta fase del ciclo celular este orgánulo sufre una drástica 
fragmentación en vesículas y túbulos para repartirse entre las dos células hijas (Shorter and Warren, 2002). El hecho de que VRK1 permanezca asociada a las membranas del aparato de Golgi a lo largo de las distintas fases de la mitosis implica que esta proteína forma un complejo estable en dicho orgánulo. Además, también se analizó la distribución de esta población tras el tratamiento con drogas que colapsan el aparato de Golgi como el nocodazol, la brefeldina $\mathrm{A}$ o el ácido okadaico (Dinter and Berger, 1998). En todos los casos, la quinasa VRK1 permanece estrechamente asociada a las membranas de este orgánulo subcelular.

Esta población de VRK1 tiene un comportamiento semejante en su localización a proteínas de la matriz de dicho orgánulo como la propia Giantina, utilizada como marcador, y quinasas como, por ejemplo, Plk3 (Ruan et al., 2004). Lógicamente, hay muchas más quinasas localizadas en el aparato de Golgi en interfase, cuya localización a lo largo de la mitosis o tras el tratamiento con agentes farmacológicos no ha sido estudiada, como, por ejemplo, la quinasa YSK1, que tiene funciones relacionadas con la migración celular (Preisinger et al., 2004). La estrecha asociación de la quinasa VRK1 con el aparato de Golgi sugiere que esté unida a las membranas bien de un modo indirecto, consecuencia de su interacción con Plk3 (tal y como se ha descrito en este trabajo), que, a su vez, interacciona con la proteína Giantina (Ruan et al., 2004); o bien a través de una interacción directa con una proteína de dicho orgánulo, como ocurre con la quinasa YSK1 que interacciona con la proteína GM130 de la matriz del aparato de Golgi (Preisinger et al., 2004). Por otro lado, esta localización también podría venir determinada por una región transmembrana, si VRK1, al igual que VRK2A, presentara una en su secuencia. Sin embargo, a diferencia de VRK2A, la quinasa VRK1 no tiene ninguna secuencia hidrofóbica que la ancle a membranas (Blanco et al., 2006). Por su parte, la población de VRK1 nuclear (identificada con el anticuerpo VC) no solapa en ningún momento con la señal de las membranas del aparato de Golgi (identificadas por Giantina), pese a encontrarse dispersa por el citoplasma en mitosis. Ambos anticuerpos detectan epítopos en VRK1 en su región carboxilo terminal (aminoácidos 332-396) (Valbuena et al., 2007a), si bien el anticuerpo 1F6 reconoce una subpoblación que ningún otro anticuerpo para VRK1 identifica, lo que sugiere que quizás la quinasa VRK1 localizada en el aparato de Golgi presenta una modificación postraduccional concreta, únicamente detectada por este anticuerpo.

Estos datos implican una posible función para VRK1 asociada con el aparato de Golgi que hasta el momento no había sido descrita. Teniendo en cuenta que las 
funciones conocidas para VRK1 están relacionadas con señalización celular, cabe pensar que esta subpoblación de VRK1 esté implicada en alguna ruta de señalización que utilice como scaffold este orgánulo, como ocurre con las MAP quinasas (Mor and Philips, 2006) o bien forme parte de alguna ruta de señalización relacionada con el transporte de vesículas, como, por ejemplo, la quinasa PKD (Protein Kinase D), que regula procesos de fisión de vesículas desde el trans-Golgi (Liljedahl et al., 2001; Hausser et al., 2005).

La presencia de VRK1 en el citoplasma y asociada al aparato de Golgi implica que sus posibles dianas de fosforilación no se restringen a proteínas nucleares, que eran los sustratos identificados hasta ahora (Sevilla et al., 2004a; Sevilla et al., 2004b; Vega et al., 2004; Nichols et al., 2006; Kang et al., 2007). Por lo tanto, la diversa localización subcelular de la quinasa VRK1 situada en el núcleo (excluida o no del nucleolo), en el citoplasma y en el aparato de Golgi indica una gran variedad de posibles funciones, todavía muchas de ellas desconocidas, además de una precisa regulación espacial de la quinasa.

\section{VRK1 y PIk3.}

\subsection{Análisis de la relación de VRK1 con la quinasa Plk3.}

En el momento de iniciar este estudio solamente se habían identificado dianas de fosforilación de VRK1, es decir, proteínas situadas downstream de VRK1 que la implicaban en diferentes rutas de señalización. Sin embargo, no se tenía conocimiento sobre proteínas reguladoras de esta quinasa. Además, considerando sus diferentes patrones de localización subcelular, la identificación de proteínas reguladoras de VRK1 podría aportar datos sobre funciones asociadas con estas subpoblaciones y permitir, por un lado, una mejor comprensión de las funciones biológicas de esta quinasa y, por otro, situarla en nuevas rutas de señalización.

En la actualidad, ya ha sido descrita una proteína reguladora de VRK1 y VRK2, la GTPasa Ran, que mediante interacción directa con las proteínas VRK regula la actividad quinasa de estas in vitro (Sanz-Garcia et al., 2008). Es decir, se habría descrito una proteína reguladora que ejerce su función a través de una interacción, pero seguiría sin haber ningún dato sobre la regulación de VRK1 mediante modificaciones postraduccionales. 
Con este fin, se analizó la secuencia de aminoácidos de VRK1 con un programa de predicción de motivos funcionales denominado ELM (Puntervoll et al., 2003). De los resultados obtenidos, parecieron de especial interés aquellos que identificaban posibles modificaciones postraduccionales en VRK1. Así, se predijeron dos sitios consenso de fosforilación para CK2 (MOD_CK2_1), un sitio consenso de fosforilación para PKA (MOD_PKA_2), dos sitios consenso de fosforilación para la familia Plk (MOD_Plk) y una secuencia consenso de sumoilación por SUMO-1 (MOD_SUMO). Para decidir qué motivo funcional debe ser objetivo de la validación experimental, hay que tener en consideración varios aspectos. Por un lado, es importante determinar si ese sitio funcional candidato es accesible en la estructura de la proteína. Para ello, el propio programa posee unos filtros que, haciendo uso de las bases de datos SMART y Pfam, permiten descartar aquellas secuencias identificadas dentro del dominio globular de la proteína (Bateman et al., 2002; Letunic et al., 2002). Por otro lado, hay que tener en cuenta la localización subcelular de la proteína estudiada respecto a su posible regulador. Es decir, si esas dos proteínas no se encuentran en el mismo compartimento subcelular in vivo, ese motivo funcional debe considerarse como falso positivo y descartarse.

En el caso de VRK1, además de validarse el sitio de fosforilación por la familia Plk (descrito en este trabajo), recientemente se ha encontrado que SUMO-1 parece estar implicada en la estabilidad de VRK1 (Klerkx et al., 2009a). La sumoilación es una modificación postraduccional que regula desde la localización subcelular de una proteína hasta su estabilidad y actividad enzimática (Anckar and Sistonen, 2007; Guo et al., 2007). De este modo, se ha determinado que la depleción de SUMO-1 mediante un ARN de interferencia específico provoca un incremento en los niveles de proteína de VRK1, lo que implica que afecta a su estabilidad o degradación (Klerkx et al., 2009a).

Este trabajo se ha centrado en el estudio de la quinasa Plk3, miembro de la familia de serina/treonina quinasas Plk, por dos motivos: la existencia de una subpoblación de Plk3 en interfase y en mitosis asociada al aparato de Golgi, que situaba a subpoblaciones de VRK1 y Plk3 en el mismo compartimento subcelular, y la identificación mediante técnicas proteómicas de Plk3 como posible proteína candidata a interaccionar con VRK1.

La identificación de Plk3 por proteómica fue estadísticamente no significativa, ya que los parámetros establecidos para las asignaciones consideraron de alta confianza una identificación con un score mayor de 54. Sin embargo, la puntuación 
obtenida para Plk3 fue de 39 con una cobertura de su secuencia solamente de un $10 \%$. Considerando que los posteriores ensayos de pulldown e inmunoprecipitación confirmaron la interacción VRK1-Plk3, hay que suponer que existió alguna limitación en el caso de la identificación de Plk3, posiblemente debida a una baja cantidad de proteína de partida y, por tanto, a un número bajo de péptidos experimentales (solamente se obtuvieron nueve) con los que realizar la asignación.

La validez de la identificación de una nueva interacción aumenta cuanto mayor y más variado es el número de experimentos que la confirman. Además, la asociación de una función biológica a esa nueva relación establecida, aporta veracidad y relevancia a esa nueva identificación. Con todo ello, en este trabajo se ha demostrado, mediante ensayos de pulldown y coinmunoprecipitación y la consecuente asignación de una función biológica, como es la fosforilación de VRK1 por Plk3, que dicha interacción es fiable.

De los dos motivos funcionales predichos para la familia Plk, uno de ellos se descartó, ya que se encontraba inaccesible dentro del dominio globular de la quinasa (secuencia consenso aa 221-227), mientras que el otro se consideró como el mejor candidato a ser fosforilado por la quinasa Plk3 (secuencia consenso DLSVVE, aa 339343). De hecho, los resultados obtenidos demuestran que la quinasa VRK1 es fosforilada en la serina 342 por la quinasa Plk3, tanto purificada como inmunoprecipitada de células, y que dicha fosforilación, no tiene lugar utilizando la proteína Plk3 sin actividad quinasa $\left(\mathrm{Plk} 3^{\mathrm{K} 52 \mathrm{R}}\right.$ ) o bien un mutante de VRK1 no fosforilable en ese residuo (VRK1 ${ }^{\mathrm{S} 342 \mathrm{~A}}$ ). Esta fosforilación es específica de VRK1, ya que el resto de los miembros de la familia VRK, que también poseen motivos consenso de fosforilación para las proteínas Plk (ver figura 32, página 75), no son diana de Plk3. Además, la quinasa Plk1 tampoco fosforila a VRK1. Por lo tanto, la fosforilación de VRK1 es muy específica dentro de la familia VRK y por la familia Plk.

La fosforilación es una modificación postraduccional que juega un papel determinante en muchas funciones celulares, regulando la actividad enzimática, la localización subcelular y la interacción con otras proteínas de la proteína sustrato en cuestión (Hanks et al., 1988; Hanks and Hunter, 1995; Yaffe and Elia, 2001). En este caso, la fosforilación de VRK1 por Plk3 en la serina 342 parece estar relacionada con la activación de la quinasa VRK1, ya que se demostró que la sobreexpresión de la quinasa Plk3 en células HEK293T inducía la activación de la quinasa VRK1 endógena, medida a través de su autofosforilación. Por otro lado, este dato apoya los resultados obtenidos en la fragmentación del aparato de Golgi inducida tras la sobreexpresión de 
Plk3 (Ruan et al., 2004), que es bloqueada al cotransfectarse con el mutante de VRK1 no fosforilable $\left(\mathrm{VRK}^{\mathrm{S} 342 \mathrm{~A}}\right)$ pero no al cotransfectarse con la quinasa VRK1 silvestre (como se ha demostrado en este trabajo). Este resultado sugiere que la quinasa Plk3 está fosforilando a VRK1 en serina 342, lo que provocaría su activación y tendría como consecuencia la fragmentación del aparato de Golgi. Si la fosforilación no tiene lugar, debido a un mutante no fosforilable, la ruta queda bloqueada. Por lo tanto, se puede pensar que la quinasa Plk3 sobreexpresada sería capaz de fosforilar a la proteína VRK1 endógena y activarla, que es lo que se detecta en el ensayo quinasa in vitro.

La estructura de la quinasa VRK1 no está todavía resuelta en la actualidad, si bien es cierto que se ha predicho que su región carboxilo terminal (aa 275-396) es flexible y probablemente responsable de la regulación de la actividad de la quinasa bien por interacción o mediante modificaciones postraduccionales (Lopez-Borges and Lazo, 2000). Por lo tanto, es lógico pensar que una fosforilación en esa región tenga un efecto sobre la actividad quinasa de VRK1, es decir, la fosforilación de VRK1 en la serina 342 localizada en su región carboxilo terminal podría tener como consecuencia

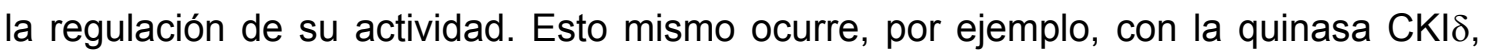
cuya fosforilación en su dominio carboxilo terminal regula su actividad quinasa (Graves and Roach, 1995).

La fosforilación de VRK1 por Plk3 constituye la identificación de la primera quinasa upstream de VRK1, además de la identificación de la primera modificación postraduccional descrita sobre la quinasa VRK1. Por otro lado, estas dos quinasas parecen formar un complejo relativamente estable in vivo como se ha demostrado mediante los diversos ensayos de pulldown e inmunoprecipitación. De los resultados obtenidos a este respecto, cabe resaltar que se ha detectado la interacción de las dos proteínas endógenas, si bien es claramente una subpoblación (en torno a un 4\%) la que interacciona. Además, el hecho de que la interacción de la quinasa VRK1 endógena con la quinasa Plk3 inactiva (Plk3 ${ }^{\mathrm{K} 52 \mathrm{R}}$ ) sea mayor que con la quinasa Plk3 silvestre apoya que VRK1 es sustrato de Plk3, de modo que, al utilizar la proteína Plk3 inactiva, la interacción es más estable porque no puede fosforilarse y permanece retenida. Aparte de la interacción entre ambas proteínas, también se ha demostrado la colocalización de estas en el citoplasma y parcialmente en el aparato de Golgi, lo que sugiere que al menos una subpoblación de ambas proteínas puede estar formando un complejo que pudiera estar asociado a las membranas del aparato de Golgi, probablemente, consecuencia de la interacción directa de Plk3 con la proteína Giantina (Ruan et al., 2004). 


\subsection{Implicación de VRK1 en la dinámica del aparato de Golgi en división celular.}

La quinasa VRK1 se caracteriza por su expresión relativamente elevada en células con alta tasa de crecimiento y por correlacionar positivamente con marcadores de proliferación como, por ejemplo, Ki67 (Nezu et al., 1997; Santos et al., 2006). Además, se le han atribuido distintas funciones a lo largo del ciclo celular, siendo clave para la transición $\mathrm{G} 0 / \mathrm{G} 1$, así como para algunas funciones mitóticas, como la compactación de la cromatina o el desensamblaje/reensamblaje de la envuelta nuclear (Nichols et al., 2006; Kang et al., 2007; Valbuena et al., 2008b). La quinasa VRK1 también se caracteriza por ser una proteína muy estable, de larga vida media (Valbuena et al., 2008b), cuya actividad quinasa es regulada en el ciclo celular (Kang et al., 2007).

En este trabajo se ha demostrado que VRK1 se activa en mitosis y que esta activación decae tras entrar en la fase G1 del ciclo celular. Sin embargo, a diferencia de lo descrito por otros autores (Kang et al., 2007), no se detectan cambios en el nivel de proteína de VRK1 en el ciclo celular ni por inmunoblot ni por inmunofluorescencia. Es decir, cambian sus niveles de actividad pero no sus niveles de proteína, al menos, en mitosis y fase $\mathrm{G} 1$ del ciclo celular.

La quinasa VRK1, al igual que otras quinasa mitóticas como, por ejemplo, Cdc2, tiene un pico de activación en aquella fase del ciclo celular en la que realiza funciones específicas, en este caso, la mitosis. Además, VRK1, al igual que estas quinasas mitóticas, tiene varias funciones en esa fase, tal y como ocurre con la quinasa Cdc2, que participa en la condensación de los cromosomas, la formación del huso mitótico, el desensamblaje de la envuelta nuclear y la fragmentación del aparato de Golgi (Nigg, 1995; Lowe et al., 1998). Para VRK1 se han descrito hasta el momento dos funciones en mitosis, por lo que cabe esperar que tenga más funciones que todavía no han sido identificadas.

Considerando la relación establecida entre las quinasas PIk3 y VRK1, las funciones descritas para Plk3 y la localización subcelular de ambas, se decidió analizar la implicación de VRK1 en la ruta de fragmentación del aparato de Golgi en mitosis, en la que se había identificado a la quinasa Plk3 situada por debajo de MEK1 (Xie et al., 2004).

Para ello se demostró que, efectivamente, el pico de actividad de VRK1 en mitosis correlacionaba con la activación de las quinasas MEK1 y Plk3, y que VRK1 se situaba por debajo de MEK1 y, por ende, de Plk3. Así, tras la sobreexpresión de MEK1, la quinasa VRK1, al igual que Plk3, se activa. Además, su actividad se ve 
reducida tras el tratamiento con el inhibidor PD98059, que inhibe a MEK1. Estos resultados sitúan a VRK1 como parte de una ruta de señalización en la que están involucradas PIk3 y MEK1. Es decir, la quinasa VRK1 sería un nuevo elemento de una ruta ya establecida en la que MEK1 señaliza la fragmentación del aparato de Golgi a través de la quinasa Plk3 entre otras y en la que VRK1 es la quinasa situada por debajo de Plk3, cuya diana de fosforilación es su serina 342 (como ha sido descrito en este trabajo).

Para demostrar que la ruta propuesta MEK1-PIk3-VRK1 funciona in vivo en la señalización de la dinámica del aparato de Golgi en división celular, se llevaron a cabo experimentos de sobreexpresión y experimentos de depleción.

Tanto la sobreexpresión de MEK1 como la de Plk3 inducen la fragmentación del aparato de Golgi de células en interfase, mientras que en células previamente tratadas con el inhibidor PD98059 se evita dicha fragmentación. Por su parte, la quinasa Plk3 inactiva (Plk3 ${ }^{\mathrm{K} 52 \mathrm{R}}$ ) es capaz de bloquear la fragmentación inducida por MEK1, lo que la sitúa por debajo de esta (Xie et al., 2004). En este trabajo se ha demostrado que el sistema funciona bajo nuestras condiciones experimentales, ya que tanto la sobreexpresión de MEK1 como la de Plk3 inducen la fragmentación de las membranas del aparato de Golgi de células HeLa en interfase, mientras que en las células que han sido previamente incubadas con el inhibidor PD98059 se evita dicho proceso. La quinasa VRK1 se sitúa como clave en la ruta MEK1-Plk3 ya que la sobreexpresión de la proteína VRK1 inactiva (VRK1 ${ }^{\mathrm{K} 179 \mathrm{E}}$ ) bloquea tanto la señalización iniciada por MEK1 como por Plk3. Esto implica, por un lado, que la quinasa VRK1 se encuentra, efectivamente, por debajo de MEK1 y PIk3 y, por otro, que la actividad quinasa de esta es necesaria para la transmisión de la señal. El hecho de que sea necesaria la actividad quinasa de VRK1, al igual que lo es la de Plk3, implica que tanto Plk3 como VRK1 tienen dianas de fosforilación que determinan que tenga lugar el proceso. En el caso de Plk3, la diana de fosforilación sería VRK1, como se demuestra al utilizar un mutante no fosforilable en serina $342\left(\mathrm{VRK} 1^{\mathrm{S} 342 \mathrm{~A}}\right)$, que bloquea la señal de Plk3. La quinasa VRK1 silvestre por sí sola no induce la fragmentación del aparato de Golgi aunque sí transmite la señal de la quinasa Plk3 sobreexpresada, lo que sugiere que necesita de una activación específica que suponemos será la fosforilación en la serina 342. De hecho, la sobreexpresión de un mutante mimético de fosforilación en ese residuo (VRK1 ${ }^{\mathrm{S} 342 \mathrm{D}}$ ) es capaz de inducir el efecto.

Como ya se ha comentado, tanto la sobreexpresión de MEK1 como de Plk3 inducen la fragmentación del aparato de Golgi (Xie et al., 2004). Sin embargo, si 
previamente se ha deplecionado la proteína VRK1 mediante ARN de interferencia específico, ni la sobreexpresión de MEK1 ni la de Plk3 son capaces de inducir el proceso de fragmentación, lo que confirma a VRK1 como un nuevo elemento en esta ruta de señalización.

La organización intracelular de módulos de señalización está bien establecida en el contexto de las MAP quinasas que se organizan en grupos de tres quinasas consecutivas normalmente mediante una proteína de anclaje en el citoplasma, aunque, en muchas ocasiones, hacen uso de compartimentos subcelulares que funcionan como sitios de anclaje (Harding et al., 2005; Mor and Philips, 2006). Sin embargo, del ensamblaje de otros complejos de señalización que impliquen otras familias de quinasas existen menos datos y, bajo este contexto, la identificación de un complejo estable Plk3-VRK1 representa un importante hallazgo, ya que, por un lado, se ha establecido una nueva ruta de señalización que utiliza como sitio de anclaje el aparato de Golgi y, por otro, se ha implicado esta ruta en una función concreta como es la fragmentación de ese orgánulo.

En la dinámica del aparato de Golgi en división celular se han establecido dos niveles de regulación (la fosforilación y la monoubiquitinación), de tal modo que este orgánulo sufre ciclos de fosforilación/desfosforilación y ubiquitinación/deubiquitinación coordinados con su desensamblaje/reensamblaje en mitosis. En la regulación mediada por fosforilación se han descrito diversas quinasas, como Plk1, ERK1c, ERK2, Cdc2 y las ya nombradas, MEK1 y Plk3. Algunas de estas quinasas parecen poder agruparse en una de las fases del proceso de fragmentación: la rotura lateral de las cisternas, donde se ha demostrado que está implicada MEK1, y el desensamblaje de estas, donde se ha demostrado que están implicadas PIk1 y Cdc2 (ver figura 15, página 43) (Acharya et al., 1998; Kano et al., 2000; Lin et al., 2000; Jesch et al., 2001a; Shorter and Warren, 2002; Colanzi et al., 2003a; Xie et al., 2004). Puesto que VRK1 se encuentra por debajo de MEK1 y Plk3, se podría suponer que está involucrada en la rotura de las uniones laterales de las cisternas. Sin embargo, no se puede confirmar si este es el caso, ya que no se han realizado experimentos específicos al respecto. E fenotipo observado por inmunofluorescencia en los ensayos realizados en este trabajo es la consecuencia de la activación de la ruta dependiente de la quinasa MEK1, lo que significa que no es el fenotipo real de la situación en mitosis donde actúan además otras proteínas. De hecho, el promedio de fragmentos obtenidos tras la sobreexpresión de MEK1 o Plk3 no es el mismo ni en número ni en tamaño que el que tiene lugar en mitosis. Se ha calculado que el número máximo y el tamaño mínimo de 
fragmentos de aparato de Golgi de células HeLa en mitosis es en torno a 130 fragmentos con un tamaño de 0,25-1 $\mu \mathrm{m}$ (Shima et al., 1997; Shima et al., 1998). El número observado en los experimentos realizados en este estudio es de 30-45 fragmentos con un tamaño de 1,5-2 $\mu \mathrm{m}$, lo que significaría que se está reproduciendo parcialmente el proceso de fragmentación.

La quinasa VRK1 tiene diversas funciones a lo largo del ciclo celular, siendo necesaria para la salida de fase G0 (Valbuena et al., 2008b) y esencial en la fase G2/M. VRK1 fosforila a la histona H3, que es necesaria para la condensación de la cromatina y la formación de una estructura cromosómica adecuada en la transición G2/M (Kang et al., 2007) y también a la proteína BAF, que se encarga del anclaje de la cromatina a la envuelta nuclear en interfase, de modo que su fosforilación por VRK1 la libera de la cromatina, permitiendo la condensación de esta y la fragmentación de la envuelta nuclear al inicio de mitosis (Nichols et al., 2006).

En este trabajo se ha demostrado que la quinasa VRK1 tiene, al menos, una función más en mitosis, donde estaría formando parte de una ruta que señaliza la fragmentación del aparato de Golgi, proceso que, además de ser necesario para el reparto de dicho orgánulo entre las dos células hijas, parece clave para la entrada en mitosis (Figura 63).

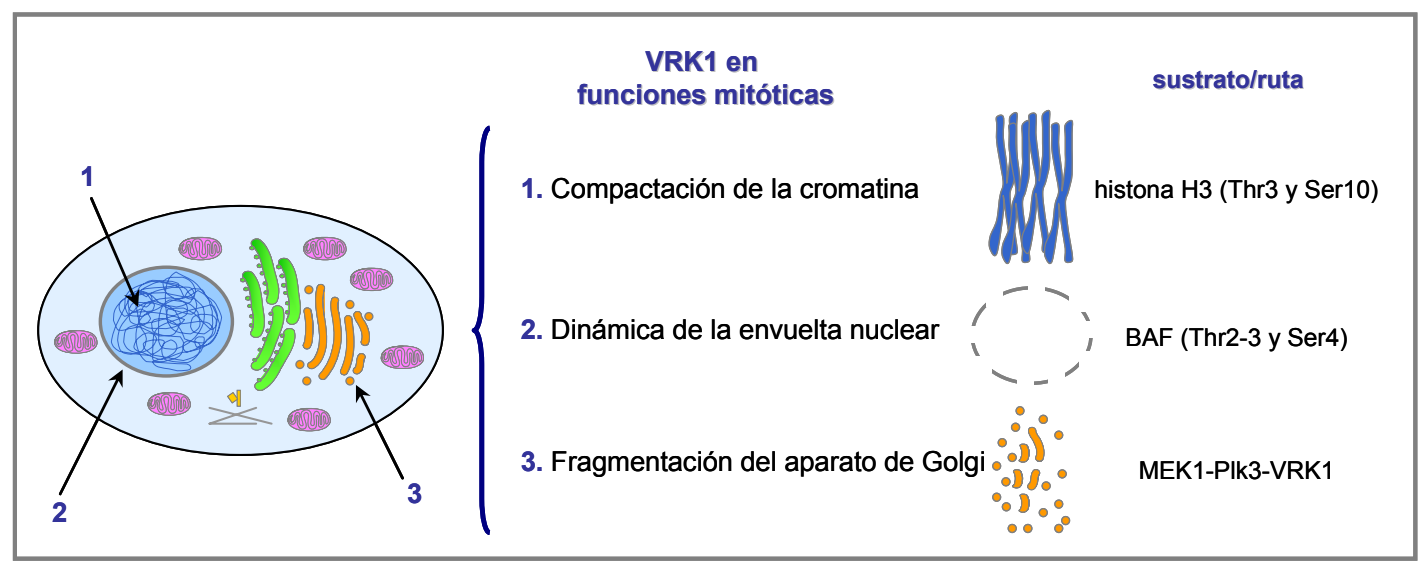

Figura 63. Funciones de VRK1 en mitosis. La quinasa VRK1 es clave en la transición G0/G1 y en mitosis con funciones en la compactación de la cromatina, la dinámica de la envuelta nuclear y la fragmentación del aparato de Golgi.

Como ya se ha comentado, en el proceso de fragmentación del aparato de Golgi en división celular son clave las quinasas y, por tanto, sus dianas de fosforilación. Los sustratos descritos hasta ahora están relacionados básicamente con 
dos procesos: el mantenimiento de la estructura de este orgánulo y los procesos de fusión. Con respecto al primer grupo, se han identificado fosforilaciones en GRASP55 y GRASP65 que tienen como consecuencia la interrupción de su oligomerización en trans, lo que lleva a la rotura de las conexiones laterales y entre cisternas del aparato de Golgi (Wang et al., 2003b; Xiang and Wang, 2010). En lo referente al segundo grupo, están las ATPasas NSF y VCP y sus proteínas relacionadas, cuyas fosforilaciones tienen como efecto la inhibición de los mecanismos de fusión, es decir, los procesos de fisión permanecen activos pero no los de fusión, lo que termina dando lugar a la fragmentación del aparato de Golgi (Misteli and Warren, 1994; Lowe et al., 1998; Uchiyama et al., 2003).

Otra de las identificaciones obtenidas del estudio de posibles proteínas candidatas a interaccionar con VRK1 fue la ATPasa VCP (datos del laboratorio). En esta ocasión, la identificación mediante técnicas proteómicas fue estadísticamente significativa con una puntuación de 133 y una cobertura en su secuencia de un 18\%. Teniendo en cuenta la función de VCP en el proceso de desensamblaje/reensamblaje del aparato de Golgi en división celular, se decidió continuar con su estudio, considerando la posibilidad de que VCP fuera la proteína diana en la fragmentación del aparato de Golgi mediada por la quinasa VRK1.

La validez de una interacción viene determinada por el número de experimentos que la confirman y la asociación de una función biológica a esa nueva relación establecida. Por ello, se realizaron diferentes ensayos de pulldown que demostraron que, efectivamente, ambas proteínas interaccionaban in vivo. Además, una interacción más estable de VCP con la quinasa VRK1 inactiva (VRK1 ${ }^{\mathrm{K} 179 \mathrm{E}}$ ), junto con la necesidad de la actividad quinasa de VRK1 para poder transmitir la señal iniciada por MEK1 y Plk3, hizo suponer que, en efecto, VCP pudiera ser sustrato de VRK1.

En los primeros ensayos quinasa realizados se usaron tanto VRK1 como VCP purificadas. En estas condiciones, se detectó que la actividad quinasa de VRK1 era menor en presencia de VCP. Previamente a estos ensayos, se había identificado a la GTPasa Ran como regulador negativo de la actividad de VRK1 in vitro a través de su interacción con la quinasa (Sanz-Garcia et al., 2008). Por tanto, para descartar que se pudiera estar ante un fenómeno similar, se llevaron a cabo experimentos quinasa con la ATPasa VCP previamente tratada con el inhibidor denominado NEM. Este inhibidor es un agente alquilante que impide la unión de ATP debido a que bloquea los grupos tioles libres sin afectar a la estructura de la ATPasa (Song et al., 2003). Se demostró 
que, cuando la ATPasa era incapaz de unir ATP, la quinasa VRK1 recuperaba los niveles normales de actividad, lo que permitió concluir que debía existir competencia por el ATP. Aún así no se logró detectar fosforilación de VCP por VRK1 mediante un ensayo quinasa clásico, lo que hizo pensar en la posibilidad de que VRK1 necesitara de alguna activación específica, ambiente concreto u otra proteína que permitiera la fosforilación de VCP.

Por ello, se decidió utilizar la quinasa VRK1 precipitada de células y, de este modo, se demostró que la ATPasa VCP era sustrato de VRK1. Por un lado, se utilizó la quinasa VRK1 inmunoprecipitada de células HEK293T y la ATPasa VCP purificada como sustrato y, por otro, la quinasa VRK1 precipitada de células mediante pulldown y un posterior ensayo quinasa de sus proteínas endógenas asociadas, siendo una de ellas la ATPasa VCP. El hecho de que la proteína VRK1 precipitada de células fuera capaz de fosforilar a VCP tanto purificada como endógena corroboró que existía algún parámetro no identificado que hacía posible dicha fosforilación. Se descartó que la fosforilación fuera consecuencia de la precipitación de otras quinasas asociadas a VRK1, ya que, ni la quinasa VRK1 inactiva (VRK1 ${ }^{\mathrm{K} 179 \mathrm{E}}$ ) ni la quinasa VRK1 silvestre tratada con fosfatasa, fosforilaban a VCP. Además, el hecho de que el tratamiento de VRK1 con fosfatasa alcalina redujera su actividad drásticamente y no fuera capaz de fosforilar a su sustrato VCP apunta a que alguna fosforilación por otra quinasa o la propia autofosforilación hacen que VRK1 sea activa. Muchas quinasas regulan su actividad catalítica a través de la autofosforilación de algún residuo en su segmento de activación, como ocurre, por ejemplo, con la quinasa MST1 (Mammalian STerile20-like 1), cuya actividad se regula mediante autofosforilación en su treonina 183 localizada en esa región (Praskova et al., 2004). En el caso de VRK1, no existen datos a este respecto. Sin embargo, hay dos treoninas altamente conservadas en su loop P+1 dentro del segmento de activación cuya fosforilación podría regular su actividad catalítica (Scheeff et al., 2009).

De los distintos cofactores que utiliza VCP para llevar a cabo sus funciones, p47 es el cofactor con el que participa en el proceso de fragmentación del aparato de Golgi en mitosis. Además, este cofactor es fosforilado por la quinasa Cdc2 provocando su deslocalización de las membranas del aparato de Golgi, lo que lleva a la inhibición de los procesos de fusión dependientes de VCP (Uchiyama et al., 2003). VRK1, a diferencia de Cdc2 no fosforila a p47 bajo ninguna de las condiciones experimentales usadas y su presencia tampoco tiene efecto sobre la fosforilación de VCP por VRK1. Es decir, la fosforilación de VCP por la quinasa VRK1 no se ve afectada por la 
presencia o ausencia del cofactor $\mathrm{p} 47$. Esto sugiere que probablemente VRK1 no fosforila a VCP en su dominio amino terminal, que es la zona de interacción con p47 (Dreveny et al., 2004). La ATPasa VCP está compuesta por cuatro dominios, la región amino terminal (aa 1-187), dos dominios ATPasa (aa 208-459 y 481-761) y una región carboxilo terminal (aa 761-806), que es la zona más flexible de la proteína y donde se han descrito muchas de sus fosforilaciones y predicho numerosos residuos susceptibles de ser fosforilados (Wang et al., 2004a; Mori-Konya et al., 2009). Así, a pesar de que no ha sido demostrado si la fosforilación por VRK1 tiene lugar en el dominio carboxilo terminal, lo más probable es que este sea el caso.

Trasladado a un contexto celular, todavía no se ha determinado qué efecto tiene esta fosforilación in vivo y su posible relación con la ruta de fragmentación de la que VRK1 forma parte. Considerando que los mecanismos de fusión deben inhibirse para que tenga lugar la fragmentación del aparato de Golgi, cabría pensar que esta fosforilación estuviera inhibiendo la actividad ATPasa de VCP, lo cual se podría descartar de la observación de los ensayos quinasa realizados, en los que se ha demostrado como VCP compite por el ATP en presencia de VRK1, lo que hace suponer que es perfectamente activa. Además, las fosforilaciones que han sido descritas para VCP tienen efecto sobre su localización y su interacción con otras proteínas pero no sobre su actividad ATPasa. Así, por ejemplo, la fosforilación por la quinasa Akt regula su interacción con proteínas ubiquitinadas, lo que las determina para su degradación por el proteasoma (Klein et al., 2005). De hecho, la fosforilación de p47 por Cdc2 tiene como consecuencia la deslocalización del complejo p47-VCP de las membranas del aparato de Golgi (Uchiyama et al., 2003). Una posibilidad sería que la quinasa VRK1, a través de la fosforilación de VCP, estuviera cooperando con Cdc2 en la deslocalización de la ATPasa. Sin embargo, con los datos de que se dispone no podemos concluir si este es el caso.

Como resultado preliminar a la relación de VRK1 y VCP in vivo, se ha demostrado que ambas están relacionadas bajo el mismo marco temporal. Como se ha explicado, la quinasa VRK1 se activa en mitosis para llevar a cabo sus funciones, al igual que MEK1 y Plk3. Se demostró que la ATPasa VCP es fosforilada tras su incubación con extractos celulares y que dicha fosforilación es máxima en mitosis, coincidiendo con la activación de VRK1. Además, al deplecionar VRK1 de células mitóticas, esa fosforilación no se detecta, lo cual hace suponer que VRK1 podría ser la quinasa responsable de la fosforilación de VCP en mitosis. Estos datos sitúan a VRK1 y VCP en una función in vivo que tiene lugar en mitosis. Ahora bien, si esa fosforilación 
está o no relacionada con la ruta MEK1-PIk3-VRK1 que lleva a la fragmentación del aparato de Golgi en mitosis, está por demostrar.

En este estudio se ha identificado a la quinasa VRK1 como un nuevo elemento de una ruta ya establecida, formada por las quinasas MEK1 y Plk3. Esta cascada de señalización utiliza como sitio de anclaje el aparato de Golgi y constituye una de las rutas por las cuales se regula la fragmentación de este orgánulo en la transición G2/M del ciclo celular. Como posible efector de la quinasa VRK1 se propone a la ATPasa VCP, cuya función debe estar bloqueada para que pueda tener lugar la fragmentación. Lógicamente, este último dato es solamente una hipótesis, ya que no se han realizado todavía experimentos específicos que involucren directamente a la ATPasa VCP como efector de la ruta MEK1-PIk3-VRK1 (Figura 64).

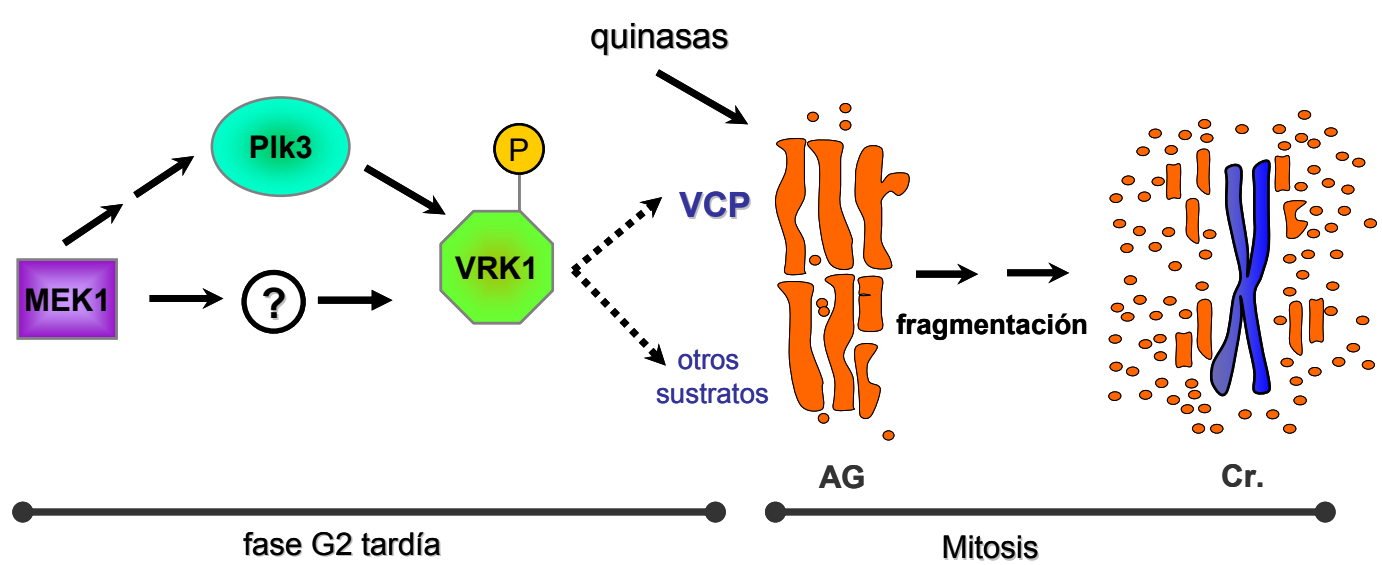

Figura 64. VRK1 y su implicación en la fragmentación del aparato de Golgi. En el diagrama se explica la situación de las quinasas MEK1, Plk3 y VRK1 en el proceso de fragmentación del aparato de Golgi en división celular. La proteína diana propuesta para VRK1 es la ATPasa VCP, aunque no se descarta que haya otras (flechas discontinuas). AG- aparato de Golgi. Cr.cromosomas. 


\section{Conclusiones}

$\sum$ Se ha identificado una subpoblación de VRK1 asociada al aparato de Golgi.

$\sum$ Esta subpoblación de VRK1 permanece asociada al aparato de Golgi en interfase, en mitosis e incluso tras el tratamiento con agentes que colapsan dicho orgánulo.

$\sum$ VRK1 forma un complejo estable con la quinasa PIk3.

$\sum$ La quinasa Plk3 fosforila a VRK1 en la serina 342, residuo que es clave para la fragmentación del aparato de Golgi inducida por MEK1 y Plk3.

$\sum$ VRK1 constituye un nuevo elemento de una ruta ya establecida en la que MEK1 señaliza la fragmentación del aparato de Golgi a través de PIk3 y esta, a su vez, a través de VRK1.

$\sum$ La ATPasa VCP es una nueva diana de fosforilación de VRK1, que se propone como posible efector de la ruta que lleva a la fragmentación del aparato de Golgi en división celular de la que VRK1 forma parte. 

Materiales y Métodos 



\section{Técnicas de manipulación de ácidos nucleicos.}

\subsection{Obtención de ADN codificante y generación de vectores recombinantes.}

Con objeto de generar y clonar el ADN codificante completo de VCP (nucleótidos 3902810), se diseñaron los oligonucleótidos VCP-BamHI y VCP-Notl basados en la secuencia de la base de datos GeneBank (NM_007126). Una vez obtenido el ADNc de células Jurkat mediante RT-PCR, se utilizó $1 \mu \mathrm{l}$ de la RT-PCR, junto con el tampón de PCR, 0,5 $\mu$ de Taq ADN polimerasa (Promega, Madison, WI, USA), $125 \mathrm{ng}$ de cada oligonucleótido, $1,5 \mathrm{mM}$ de $\mathrm{MgCl}_{2}$ y $1 \mu \mathrm{l}$ de dNTPs (Boehringer Mannheim Corporation, Indianápolis, USA) en un volumen final de $50 \mu \mathrm{l}$. La amplificación se llevó a cabo según el siguiente programa de PCR: 10 minutos a $95^{\circ} \mathrm{C}, 30$ ciclos de 1 minuto a $95^{\circ} \mathrm{C}, 40$ segundos a $55^{\circ} \mathrm{C}$ y 40 segundos a $72^{\circ} \mathrm{C}$ y, por último, un ciclo de terminación de 10 minutos a $72^{\circ} \mathrm{C}$. El producto de PCR se clonó en el vector comercial pCR2.1 según las instrucciones del sistema TA Cloning Kit (Invitrogen, San Diego, CA, USA). Los productos ya clonados fueron secuenciados y subclonados a los vectores de destino.

El resto de las construcciones generadas para este estudio fueron subclonaciones directas de las secuencias de ADNc de unos vectores a otros mediante reacciones de digestión y posterior reacción de ligación. En algunos casos, las enzimas de restricción no eran las indicadas y se generaron nuevos sitios de restricción para la subclonación mediante PCR y oligonucleótidos específicos utilizando como ADN molde el ADNc. Para las reacciones de digestión se usaron enzimas de restricción (Promega, Madison, WI, USA o Fermentas Inc, MD, USA) y la reacción de ligación se llevó a cabo con la enzima T4 ADN ligasa (Promega, Madison, WI, USA) según Sambrook (2001) (Sambrook, 2001). Las construcciones obtenidas se transformaron en las cepas de Escherichia coli DH5a o BL21DE3, que se seleccionaron utilizando antibióticos específicos para cada vector. Así, se aislaron y guardaron aquellos clones que habían incorporado la construcción correcta. La confirmación de cada clon se realizó mediante enzimas de restricción, electroforesis en geles de agarosa y, por último, secuenciación.

\subsection{Aislamiento de ADN plasmídico.}

El método usado para el aislamiento de ADN plasmídico a pequeña escala a partir de E.coli fue la lisis alcalina, descrito por Birboim y Doly (1979) (Birnboim and Doly, 1979). 
El aislamiento de ADN plasmídico a gran escala (Maxiprep) se realizó mediante el sistema comercial JETStar Maxi Kit (Genycell Biotech España, Granada, España).

\subsection{Determinación de la concentración de ácidos nucleicos.}

La concentración de ADN se determinó midiendo la absorbancia a $260 \mathrm{~nm}$ en un espectrofotómetro U-2001 UV/Visible (HITACHI). Para ello, se consideró la relación de absorbancia 260/280 nm. Esta concentración se corroboró mediante electroforesis en geles de agarosa.

\subsection{Electroforesis de fragmentos de ADN.}

La separación de fragmentos de ADN en función de su tamaño se realizó mediante electroforesis en geles de agarosa preparados entre un $0,8 \%$ y un $1,2 \%$ de agarosa, según el caso. El tampón de carga estaba compuesto por 0,25\% Bromophenol Blue y $15 \%$ Ficoll en agua. El tampón de carrera en todos los casos fue TAE (Tris-acetato 40 mM, EDTA $1 \mathrm{mM}$ ). El marcador de tamaño de ADN utilizado fue $1 \mathrm{~Kb}$ Ladder (BIOTOOLS, Biotech \& Medical laboratories, Madrid, España).

\subsection{Transformación.}

Los plásmidos utilizados se transformaron en bacterias $E$. coli competentes de las cepas DH5a o BL21DE3, según fueran para obtener ADN o proteína.

La transformación, en todos los casos, se realizó por choque térmico. Para ello, primero se incubaron a $4^{\circ} \mathrm{C}$ durante 20 minutos. A continuación, se procedió con un choque térmico de 5 minutos a $37^{\circ} \mathrm{C}$. Después, se incubaron a $4^{\circ} \mathrm{C}$ durante 5 minutos y se les añadió $1 \mathrm{ml}$ de medio LB. De este modo, se incubaron 1 hora en agitación a $37^{\circ} \mathrm{C}$ (tiempo durante el cual se expresa el gen de resistencia a antibióticos). Transcurrido este tiempo, se plaquearon en placas de Petri de LB-agar con el antibiótico de selección correspondiente, normalmente ampicilina (50 $\mu \mathrm{g} / \mathrm{ml})$. Las placas se incubaron $12-16$ horas a $37^{\circ} \mathrm{C}$ y después se procedió al análisis de las colonias obtenidas.

\section{Mutagénesis dirigida.}

Para realizar la mutagénesis en nucleótidos puntuales, se utilizó el método recomendado por el sistema comercial QuickChange Site-Directed Mutagenesis (Stratagene, San Diego, California, USA). 
Para ello, se utilizaron como sustrato $50 \mathrm{ng}$ de ADN, $125 \mathrm{ng}$ de cada oligonucleótido, $1 \mu \mathrm{l}$ de dNTPs (Boehringer Mannheim Corporation, Indianápolis, USA), tampón de PCR $\left[\mathrm{KCl} 100\right.$ mM, $\left(\mathrm{NH}_{4}\right) \mathrm{SO}_{4} 100$ mM, Tris-HCl 200 mM pH 8,8, MgSO 20 $\mathrm{mM}$, Tritón X-100 1\%, BSA $1 \mathrm{mg} / \mathrm{ml}$, de Stratagene, San Diego, California, USA] y una unidad de la enzima Pfu Turbo DNA Polimerase (Stratagene, San Diego, California, USA) en un volumen final de $50 \mu \mathrm{l}$. Para la mutación de una sola base, las condiciones de la reacción fueron un Hot Start de 15 minutos a $95^{\circ} \mathrm{C}$ previo a la adición de la enzima. Tras la adición de la enzima, los ciclos fueron de $95^{\circ} \mathrm{C}$ durante 30 segundos, seguido de 16 ciclos que consistían en 90 segundos a $95^{\circ} \mathrm{C}, 90$ segundos a $55^{\circ} \mathrm{C}$ y una elongación de 15 minutos a $68^{\circ} \mathrm{C}$. Tras la reacción de PCR, el ADN sustrato se eliminó mediante la endonucleasa Dpnl (Promega, Madison, WI, USA). Esta endonucleasa se caracteriza por su acción específica sobre secuencias metiladas y hemimetiladas, resultando así seleccionadas las copias mutantes. El producto de PCR así tratado se analizó mediante electroforesis en geles de agarosa y se transformó en cepas competentes DH5a o BL21E3 de E. coli según la finalidad.

\section{Purificación de proteínas de fusión.}

\subsection{Purificación de proteínas de fusión unidas a GST.}

La expresión y purificación de proteínas de fusión unidas a GST (Glutatión-STransferasa, Amersham Biosciences) se realizó a partir de plásmidos transformados en la cepa BL21DE3 de E. coli. Para ello, los clones se crecieron $12-16$ horas a $37^{\circ} \mathrm{C}$ en agitación en medio selectivo (LB con ampicilina $50 \mu \mathrm{g} / \mathrm{ml}$ ). A continuación, se realizó una dilución 1:10 del preinóculo en medio selectivo fresco y se dejó crecer hasta alcanzar una densidad óptica a $600 \mathrm{~nm}$ de 0,6-0,8. En ese momento, cuando el cultivo se encuentra en fase exponencial, se indujo la expresión de la proteína de fusión, añadiendo IPTG (Boehringer Mannheim Corporation, Indianápolis, USA) hasta una concentración final de 0,1-1 $\mathrm{mM}$ y se incubó de 2-4 horas. Tras ese tiempo, el cultivo se centrifugó a $10.000 \mathrm{rpm}$ durante 10 minutos. Se retiró el sobrenadante y se procedió a resuspender las células en tampón de lisis (PBS 1X frío, 1\% Tritón X-100, 0,2 $\mu \mathrm{g} / \mathrm{ml}$ lisozima, $1 \mathrm{mM}$ PMSF, $5 \mathrm{mM}$ DTT, $10 \mu \mathrm{g} / \mathrm{ml}$ aprotinina, $10 \mu \mathrm{g} / \mathrm{ml}$ leupeptina). La supensión se sonicó a baja potencia con cinco pulsos de 10 segundos cada uno a $4^{\circ} \mathrm{C}$ en un sonicador Misonic XL2010. Se incubó 30 minutos en hielo y después se centrifugó 30 minutos a $30.000 \mathrm{rpm}$ a $4^{\circ} \mathrm{C}$. El sobrenadante resultante contiene las proteínas solubles, entre las cuales se encuentra de modo mayoritario la proteína de 
fusión expresada. Esta fracción soluble se incubó 12 horas con la resina Glutathion Sepharose (Glutathion Sepharose 4B beads, Amersham Biosciences, Uppsala, Suecia) en agitación vertical suave. Una vez unida la proteína de fusión a la resina, se lavó la resina varias veces en tampón de lisis (sin lisozima). La pureza de la proteína obtenida se analizó por electroforesis SDS-PAGE seguida de tinción Coomassie o inmunoblot.

La concentración proteica se determinó por colorimetría mediante Bio-Rad Protein Assay (Bio-Rad, Hércules, CA, USA), utilizando BSA para establecer una recta patrón.

Algunas proteínas de fusión se separaron de su epítopo GST por digestión con trombina (10 unidades/mg de proteína de fusión) de 16-20 horas a temperatura ambiente. A continuación, se centrifugó durante 5 minutos a 1.800 rpm y se guardó el sobrenadante, correspondiente a la proteína purificada.

\subsection{Purificación de proteínas de fusión unidas al epítopo 6xHis.}

El protocolo utilizado fue el mismo que para la purificación de proteínas de fusión unidas a GST, salvo que el tampón de lisis contiene $10 \mathrm{mM}$ de imidazol (Merck, Darmstadt, Alemania) y carece de DTT. La resina usada en este caso fue TALON Metal Affinity Resin (BD Biosciences, Palo Alto, CA, USA) con afinidad por histidinas.

\section{Tinción con azul de Coomassie.}

Para monitorizar el proceso de purificación y para comprobar la correcta expresión de las proteínas, las distintas fracciones proteicas obtenidas se separan por tamaño mediante electroforesis en geles SDS-PAGE. Los geles de poliacrilamida se tiñeron con solución Coomassie (0,5\% de Coomassie Brilliant Blue R250, 50\% metanol, 10\% ácido acético glacial) durante 10 minutos a temperatura ambiente y se destiñeron con solución de distinción (50\% metanol, 10\% ácido acético glacial) en agitación hasta la correcta visualización de las bandas de interés. Finalmente, los geles se secaron en un secador de geles (Biorad) durante 2 horas a $80^{\circ} \mathrm{C}$.

\section{Tinción con Ponceau.}

Se trata de un método de tinción reversible que se utiliza para teñir proteínas en membranas de PVDF (Immobilon-P Tranfer Membrane, Millipore). La solución de tinción está compuesta por $0,2 \%$ Ponceau (ácido 3-Hidroxi-4[2-sulfo-4-(4-sulfofenilazo) fenilazo]-2,7-naftalenodisulfónico), $3 \%$ ácido sulfosalicílico, $3 \%$ ácido 
tricloroacético y $1 \%$ ácido acético en PBS. Para teñir las membranas, se incubaron en tinción Ponceau 30 minutos a temperatura ambiente. A continuación, se destiñeron lavando con agua destilada hasta visualizar las bandas de interés.

\section{Ensayos de actividad quinasa in vitro.}

La actividad serina-treonina quinasa se analizó mediante ensayos quinasa in vitro. Para ello, se utilizaron aproximadamente de 2-5 $\mu \mathrm{g}$ de proteína quinasa y de $5-10 \mu \mathrm{g}$ de proteína sustrato. Para cada tipo de análisis se usó un tampón quinasa específico. En todos los ensayos se añadieron $5 \mu \mathrm{M}$ de ATP $-\mathrm{Mg}^{2+}$ y $5 \mu \mathrm{M}(5 \mu \mathrm{Ci})$ de $\left[\gamma^{32} \mathrm{P}\right]$ ATP y se ajustó la reacción a un volumen final de 25-50 $\mu$ l. La mezcla se incubó durante 30 minutos a $30^{\circ} \mathrm{C}$ en agitación en un agitador Thermomixer Compact de Eppendorf. Posteriormente, las muestras fueron procesadas y fraccionadas en un gel de poliacrilamida de un porcentaje adecuado al tamaño de las proteínas. Así mismo, según el tipo de ensayo el gel fue teñido con tinción de Coomassie, como se ha descrito con anterioridad, o bien las proteínas fueron transferidas a una membrana de PVDF (Millipore) mediante transferencia húmeda para su posterior análisis por inmunoblot o tinción con Ponceau. La radioactividad incorporada se detectó mediante autorradiografía en películas de rayos $X$ (Fujifilm) con exposiciones desde minutos a horas, según cada caso. La interpretación de las señales de fosforilación se realizó utilizando como referencia el gel teñido con Coomassie, el resultado del inmunoblot o la membrana teñida con Ponceau.

En algunos ensayos, la quinasa o el sustrato utilizado fue previamente precipitado mediante la técnica de pulldown o bien por inmunoprecipitación. Tras varios lavados con el mismo tampón empleado para la precipitación se realizó el ensayo quinasa siguiendo el protocolo ya descrito. La cantidad de extracto proteico utilizada para la precipitación fue de 1-2 mg según el ensayo.

\subsection{Ensayos de actividad quinasa in vitro para VRK1.}

En aquellos ensayos en los cuales se analizó la actividad de VRK1, el tampón quinasa utilizado fue el de las caseína quinasas, el cual consiste en $50 \mathrm{mM}$ Tris- $\mathrm{HCl} \mathrm{pH}$ 7,5, 5 $\mathrm{mM} \mathrm{MgCl} 2,0,5 \mathrm{mM}$ DTT, $150 \mathrm{mM} \mathrm{KCl}$.

\subsection{Ensayos de actividad quinasa in vitro para las proteínas PIk.}

En aquellos ensayos en los que se analizó la actividad de Plk3, el tampón quinasa utilizado fue el siguiente: $30 \mathrm{mM}$ Hepes $\mathrm{pH}$ 7,4, $10 \mathrm{mM} \mathrm{MgCl} 2,1 \mathrm{mM}$ DTT y para los 
ensayos con Plk1, el tampón quinasa estaba compuesto por $20 \mathrm{mM}$ Hepes pH 7,4, $150 \mathrm{mM} \mathrm{KCl}, 10 \mathrm{mM} \mathrm{MgCl}_{2,}, 1 \mathrm{mM}$ EDTA, 0,5 mM DTT, $5 \mathrm{mM} \mathrm{NaF}$.

\subsection{Ensayos de actividad quinasa in vitro para MEK1.}

En los ensayos en los que se usó como quinasa la proteína MEK1, el tampón utilizado fue el siguiente: $20 \mathrm{mM}$ Tris- $\mathrm{HCl}$ pH 7,4, $20 \mathrm{mM} \mathrm{NaCl}, 10 \mathrm{mM} \mathrm{MgCl}, 1 \mathrm{mM}$ DTT.

\section{Cultivo celular.}

Las líneas celulares usadas se cultivaron en flasks o placas para cultivo celular en monocapa dentro de un incubador a $37^{\circ} \mathrm{C}$ con una atmósfera del $5 \% \mathrm{CO}_{2}$ y un $98 \%$ de humedad relativa. Todos los medios de cultivo fueron suplementados con $10 \%$ FBS, LGlutamina a $2 \mathrm{mM}$, y los antibióticos penicilina a 50 unidades $/ \mathrm{ml}$ y estreptomicina a 50 $\mu \mathrm{g} / \mathrm{ml}$. Para levantar las células se usó Tripsina-EDTA. Los medios y suplementos se obtuvieron de GIBCO (Invitrogen).

Las diferentes líneas celulares se observaron con un microscopio óptico invertido Zeiss Axiovert 25. Para hacer las fotos se usó una cámara digital (HAMAMATSU) asociada a un microscopio óptico invertido Zeiss Axiovert 135.

\section{Transfecciones transitorias de ADN en células de mamífero en cultivo} monocapa.

Para todos los experimentos de sobreexpresión de proteínas en células eucariotas se realizaron transfecciones transitorias de ADN en células en cultivo. Para ello, se sembraron las células 24 horas antes de la transfección a una densidad de modo que se encuentraran entre un $60-80 \%$ de confluencia en el momento de la transfección. Las células se transfectaron con las construcciones de ADN indicadas en cada experimento con uno de los siguientes reactivos:

a) Transfección con el reactivo JetPEI ${ }^{\mathrm{TM}}$ Cationic Polymer Transfection Reagent (Polyplustransfection, Illkirch, Francia). Se diluyeron por separado el ADN y el reactivo JetPEI en un volumen determinado de $150 \mathrm{mM} \mathrm{NaCl}$, en una proporción $N / P=5$ (ratio que indica el número de residuos de nitrógeno del reactivo por fosfato del ADN, que sería la medida del balance iónico de los complejos). A continuación, se mezcló cada una de las muestras y se añadió la solución de JetPEl sobre la solución de ADN. Esta mezcla se incubó a temperatura ambiente de 15-30 minutos. Por último, se añadió a las células y se homogeneizó con el medio de cultivo. 
b) Transfección con el reactivo Lipofectamine 2000 Reagent (Invitrogen). Se diluyeron por separado el ADN y el reactivo Lipofectamine en un volumen determinado de Opti-MEM (GIBCO, Invitrogen), en una relación de $\mu g$ de ADN/ $\mu$ l de Lipofectamine de 1/3. Se mezcló cada una de las muestras y, tras 5 minutos se añadió la solución de Lipofectamine sobre la solución de ADN. Esta mezcla se incubó a temperatura ambiente 20 minutos. A continuación, se añadió a las células y se homogeneizó con el medio de cultivo sin antibióticos. Tras 12 horas se cambiaron las células a medio fresco con antibióticos.

En todos los casos se mantuvo la cantidad de ADN transfectado constante mediante la adición de un vector vacío específico para cada ensayo. Como control de la eficiencia de transfección se utilizó un vector para la expresión eucariota de la proteína fluorescente verde GFP (Green Fluorescent Protein).

9. Transfecciones transitorias de ARNi en células de mamífero en cultivo monocapa.

La supresión de la expresión de VRK1 se realizó mediante dos métodos de ARN de interferencia. Por un lado, se utilizaron dúplex de ARN de interferencia ( $\operatorname{siRNA}$ ), diseñados usando el algoritmo SMARTselection (Thermo Fisher Scientific., Lafayette, CO, USA). EI ARNi utilizado para silenciar la quinasa humana VRK1 se denomina siGENOME siRNA-02. Como control se utilizó un ARN de interferencia funcional sin diana en células humanas denominado ON-TARGETplus siControl non-targeting siRNA (Thermo Fisher Scientific., Lafayette, CO, USA). Se transfectaron de manera transitoria utilizando Lipofectamine 2000 (Invitrogen), según las instrucciones del fabricante a una concentración de $80 \mathrm{nM}$. Tras la transfección, se esperó el tiempo necesario según el ensayo y se procedió a realizar ensayos de inmunofluorescencia, inmunoblot y en algunos casos se hicieron fotos en un microscopio óptico. La secuencia diana para VRK1 se especifica en la tabla V.

Por otro lado, se utilizó el sistema de ARN de interferencia por pSUPER (Oligoengine, DNAengine, Seattle, WA, USA). Se trata de vectores de expresión en eucariotas que dirigen la síntesis de ARN de interferencia dentro de las células. Se diseñaron secuencias específicas para la quinasa humana VRK1 con el programa Oligoengine (http://www.oligoengine.com/). Estas secuencias se clonaron en el laboratorio en los vectores pSUPER, según las instrucciones del fabricante. Como control de estos ensayos se utilizó el vector vacío (pSUPERØ). En estos casos, las 
transfecciones se realizaron con el reactivo JetPEI ${ }^{\mathrm{TM}}$ Cationic Polymer Transfection Reagent (Polyplustransfection, Illkirch, Francia).

\section{Electroforesis en geles SDS-PAGE e inmunoblot de extractos proteicos.}

Para la obtención de extractos proteicos totales de células en cultivo, las células se lavaron tres veces con PBS frío y, en todos los casos, se recogieron directamente con un tampón de lisis específico. Para cada ensayo, se utilizó un tampón específico. A todos los tampones de lisis se les añadieron inhibidores de proteasas y fosfatasas (1 mM PMSF, $10 \mu \mathrm{g} / \mathrm{ml}$ aprotinina, $10 \mu \mathrm{g} / \mathrm{ml}$ leupeptina, $1 \mathrm{mM}$ DTT, $1 \mathrm{mM}$ ortovanadato sódico, $1 \mathrm{mM}$ fluoruro sódico), salvo algunas excepciones en las que se indica. Se incubaron 30 minutos en hielo y se centrifugaron durante 20 minutos a $13.000 \mathrm{rpm}$ a $4^{\circ} \mathrm{C}$. Se recuperó la fracción soluble y se midió la concentración de proteína total por espectrometría con el reactivo Bio-Rad Protein Assay (Bio-Rad, Hércules, CA, USA) utilizando BSA de concentración conocida para hacer la curva patrón.

Se resolvió una cantidad igual en todos los puntos de extracto proteico (20-50 $\mu \mathrm{g}$ ) mediante electroforesis vertical en gel SDS-PAGE (sodium-dodecylsulfatepolyacrilamide gel electrophoresis) con un porcentaje de acrilamida adecuado al tamaño de la proteína a analizar. Para ello, las diferentes muestras se procesaron con tampón de carga desnaturalizante $(62,5 \mathrm{mM}$ Tris- $\mathrm{HCl} \mathrm{pH} 6,8,10 \%$ glicerol, 2,3\% SDS, $0,1 \%$ azul de bromofenol, $5 \% \beta$-mercaptoetanol) y se hirvieron durante 5 minutos. El gel se corrió en condiciones desnaturalizantes en tampón de carrera adecuado (25 mM Tris, 192 mM glicina, 1,7 mM SDS) según (Laemmli, 1970). Como marcadores de peso molecular se utilizaron marcadores preteñidos Precision Plus Protein Standards Dual Color de Bio-Rad.

Las proteínas fueron transferidas a una membrana de PVDF (Immobilon-P tranfer membrana, Millipore) mediante transferencia húmeda en tampón de transferencia (25 mM Tris, 19,2 mM glicina, de 10-20\% metanol) según (Towbin et al., 1979).

\subsection{Tampones de lisis.}

Para cada tipo de ensayo se utilizó un tampón de lisis específico. Así, para los ensayos de pulldown su composición fue la siguiente: $20 \mathrm{mM}$ Tris- $\mathrm{HCl}$ pH 7,4, $137 \mathrm{mM}$ $\mathrm{NaCl}, 2 \mathrm{mM}$ EDTA, $25 \mathrm{mM} \beta$-glicerofosfato, $2 \mathrm{mM}$ pirofosfato tetrasódico, 10\% glicerol, $1 \%$ tritón X-100. Para los ensayos de coinmunoprecipitación, el tampón fue el siguiente: $50 \mathrm{mM}$ Tris-HCl pH 7,5, $150 \mathrm{mM} \mathrm{NaCl}, 1 \%$ IGEPAL, 1 mM EDTA. Para los 
ensayos de inmunoprecipitación y posterior ensayo quinasa el tampón estaba compuesto por $20 \mathrm{mM}$ Tris- $\mathrm{HCl} \mathrm{pH}$ 8, $140 \mathrm{mM} \mathrm{NaCl}, 10 \mathrm{mM}$ EDTA, 10\% glicerol, 1\% IGEPAL.

\section{Precipitación de proteínas mediante tricloroacético.}

Para concentrar las proteínas que se encuentran en fracciones proteicas diluidas y poder determinar la presencia de la proteína de interés mediante inmunoblot, se llevó a cabo el siguiente protocolo de precipitación. En primer lugar, se añadió tricloroacético a un $10 \%$. Se mezcló y se centrifugó durante 15 minutos a $15.000 \mathrm{rpm}$ a $4^{\circ} \mathrm{C}$. Se eliminó el sobrenadante y el precipitado se lavó con acetona fría (100 $\left.\mu \mathrm{l}\right)$. Se centrifugó de nuevo durante 15 minutos a $15.000 \mathrm{rpm}$ a $4^{\circ} \mathrm{C}$, se eliminó la acetona y se dejó secar al aire. Por último, se resupendió el precipitado en $50 \mu \mathrm{l}$ de tampón de carga desnaturalizante $1 \mathrm{X}$ y se hirvieron las muestras durante 5 minutos. En este momento, las muestras ya están listas para proceder a la electroforesis en geles SDSPAGE y posterior inmunoblot.

\section{Fraccionamientos celulares.}

12.1. Aislamiento del aparato de Golgi de células de mamíferos en cultivo monocapa según (Balch et al., 1984) por gradiente discontinuo de sacarosa.

Se partió de extractos proteicos totales $\left(5 \cdot 10^{5}\right.$ células $\left./ \mathrm{ml}\right)$ que fueron lisados en un tampón específico compuesto de $0,25 \mathrm{M}$ sacarosa y $10 \mathrm{mM}$ Tris- $\mathrm{HCl} \mathrm{pH} 7,4$. El lisado fue diluido en un volumen final de $6 \mathrm{ml}$ y homogeneizado. A este homogeneizado, se le añadieron $6 \mathrm{ml}$ de un tampón compuesto de 2,3 M sacarosa y $10 \mathrm{mM}$ Tris- $\mathrm{HCl} \mathrm{pH}$ 7,4 para alcanzar una concentración final de 1,4 M sacarosa. A continuación, se añadió $1 \mathrm{mM} \mathrm{Na}_{2}$ EDTA. La mezcla se colocó en un tubo Ultra-Clear de centrifugación SW28 (25 x 89 mm) de BECKMAN (Beckman Instruments, Inc, Palo Alto, CA, USA) y se añadieron $14 \mathrm{ml}$ de 1,2 M sacarosa y $10 \mathrm{mM}$ Tris- $\mathrm{HCl} \mathrm{pH} \mathrm{7,4}$ y, por último, $9 \mathrm{ml}$ de $0,8 \mathrm{M}$ sacarosa y $10 \mathrm{mM}$ Tris- $\mathrm{HCl} \mathrm{pH} 7,4$. El gradiente se centrifugó a $90.000 \mathrm{~g}$ durante 2 horas y 30 minutos. Después, se recogieron fracciones de $2 \mathrm{ml}$ en torno a la zona del gradiente de 0,8 M-1,2 M de sacarosa. En total se recogieron 16 fracciones. Las proteínas contenidas en las diferentes fracciones fueron precipitadas con tricloroacético y analizadas por inmunoblot. 


\subsection{Fraccionamiento membranas-citoplasma.}

Se trata de una técnica para separar membranas de la fracción citoplasmática de extractos proteicos. Para ello, el lisado celular $(500 \mu \mathrm{l})$ se centrifugó a $13.200 \mathrm{rpm}$ durante 2 minutos a $4^{\circ} \mathrm{C}$. El precipitado se descartó y el sobrenadante, del que se tomó una alícuota, se volvió a centrifugar a $100.000 \mathrm{~g}$ durante 1 hora a $4^{\circ} \mathrm{C}$. En esta ocasión, no se descartó el sobrenadante, ya que se trataba de la fracción citosólica, si bien el precipitado se resuspendió en $100 \mu$ de tampón de lisis con 1\% Tritón X-100. Se incubó en hielo 1 hora y después se sometió a una nueva centrifugación de $100.000 \mathrm{~g}$ durante 1 hora a $4^{\circ} \mathrm{C}$. El sobrenandante resultante de esta centrifugación contiene las membranas. Por último, se procedió a analizar las proteínas contenidas en las distintas fracciones: lisado total, citoplasma y membranas por inmunoblot.

\section{Inmunoprecipitación.}

Las inmunoprecipitaciones se llevaron a cabo a partir de 1-2 mg de extracto proteico total. Los extractos fueron lisados en un tampón de lisis específico. En primer lugar, se realizó una preincubación con $20 \mu \mathrm{l}$ de resina Gamma-Bind G Plus Sepharose Beads (GE Healthcare) para evitar las uniones inespecíficas durante 30 minutos a $4^{\circ} \mathrm{C}$ en agitación orbital. A continuación, se eliminó la resina y se incubaron los extractos preclareados con el anticuerpo correspondiente para cada ensayo de 12-16 horas a $4^{\circ} \mathrm{C}$ en agitación orbital. Después, se añadieron $30 \mu \mathrm{l}$ de la resina bloqueada previamente con BSA al $1 \%$ en PBS. Esta mezcla se incubó 2 horas a $4^{\circ} \mathrm{C}$ en agitación orbital. Tras este tiempo, la resina se recogió por centrifugación suave (2.000 rpm) y se lavaron varias veces con el mismo tampón de lisis. Por último, se procesaron y se analizaron mediante geles de SDS-PAGE e inmunoblot.

14. Ensayos de interacción por precipitación de proteínas de fusión con GST (ensayos de pulldown).

Estos ensayos se realizaron para precipitar complejos de proteínas fusionadas a GST utilizando proteínas purificadas de bacterias que se incubaron con extractos celulares o bien proteínas de expresión en células eucariotas. Se utilizaron de 1-2 mg de extracto proteico total recogido en un tampón de lisis específico. Para precipitar las proteínas de fusión con GST, se incubaron los extractos con $20 \mu \mathrm{l}$ de resina Glutathion Sepharose 4B Beads (Amersham Biosciences, Uppsala, Suecia) de 4-12 horas a $4^{\circ} \mathrm{C}$ en agitación orbital. Tras este tiempo, se recogió la resina por centrifugación suave y se lavó varias veces con el mismo tampón de lisis. A continuación, las muestras se 
procesaron y las proteínas precipitadas se analizaron mediante electroforesis en geles SDS-PAGE e inmunoblot.

\section{Ensayos de interacción in vitro.}

El ensayo de interacción in vitro del apartado 2.10.2 de la sección de resultados se llevó a cabo con proteínas purificadas fusionadas a GST o al epítopo 6xHis. Las proteínas se incubaron en $250 \mu \mathrm{l}$ del tampón VCP $(25 \mathrm{mM}$ Tris-HCl, pH 8, $200 \mathrm{mM}$ $\mathrm{KCl}, 2 \mathrm{mM} \mathrm{MgCl}$, $1 \mathrm{mM}$ ATP, $1 \mathrm{mM}$ DTT, 5\% Glicerol, 1\% Tritón X-100) con la resina Glutathion Sepharose (Amersham Biosciences, Uppsala, Suecia) durante $2 \mathrm{~h}$ a $4^{\circ} \mathrm{C}$. Los precipitados se lavaron extensamente con el mismo tampón, se procesaron con tampón de carga y las proteínas precipitadas se analizaron mediante electroforesis en geles SDS-PAGE e inmunoblot.

\section{Inmunofluorescencia.}

Para detectar la localización subcelular de proteínas sobreexpresadas o endógenas en células en cultivo, se llevaron a cabo ensayos de inmunofluorescencia. Para ello, las células fueron sembradas sobre cubreobjetos de vidrio estériles. En el caso de la línea celular HEK293T, estos cubreobjetos fueron previamente tratados con Poly-L-lysine (Sigma-Aldrich.Inc, St. Louis, MO, USA). Para ensayos con proteínas sobreexpresadas, las células fueron transfectadas como se especifica en el apartado 8. Transcurridas 12-24 horas, según el tipo de estudio, las células fueron lavadas con PBS frío varias veces y fijadas mediante p-formaldehído al $3 \%$ en PBS durante 30 minutos a temperatura ambiente. A continuación, las células fueron tratadas con Glicina $10 \mathrm{mM}$ durante 10 minutos a temperatura ambiente para bloquear los sitios aldehído libres. Después se permeabilizaron con Tritón X-100 al $0,1 \%$ en PBS. Se bloquearon con $1 \%$ de BSA en PBS durante 30 minutos a temperatura ambiente y se incubaron con el anticuerpo primario durante 1 hora a $37^{\circ} \mathrm{C}$. Tras varios lavados con PBS, se incubaron con el anticuerpo secundario específico marcado con fluorocromo (Cy2-verde o Cy3-rojo). Tras otra serie de lavados con tampón PBS, se tiñeron los núcleos celulares con DAPI (4'-6'-diamidino-2-fenilindol) durante 10 minutos en PBS a temperatura ambiente. Finalmente, se montaron los cubreobjetos sobre portaobjetos que se sellaron con Gelvatol (Monsanto, St. Louis, MO, USA) o Vectashield (Vector laboratorios.Inc, Burlingame, CA, USA). La localización subcelular se analizó mediante microscopía confocal utilizando un microscopio confocal Zeiss LSM510. Las imágenes así adquiridas se analizaron con el programa LSM Image Examiner de Zeiss. En el 
caso de análisis de partículas o grado de colocalización se utilizó el programa ImageJ (http: rsb.info.nih.gov/ij) desarrollado por Wayne Rasband (Nacional Institutes of Health, Bethesda, MD). Para la medida cuantitativa del grado de colocalización se utilizaron varios métodos:

- Coeficiente de correlación de Pearson $\left(R_{r}\right)$. Se trata de un método cuyos valores van de +1 a -1 . Un valor de +1 sería una correlación perfecta; -1 significa una perfecta exclusión y cero una correlación aleatoria (Manders, 1992).

- Coeficiente de Mander (R). Los valores que se obtienen con este método van de cero a +1 . En este caso, un valor cero significa poca colocalización y 1 alta colocalización (Manders, 1993).

- Cociente de correlación de la intensidad (ICQ). Los valores obtenidos van de $-0,5$ a $+0,5$. De modo que un valor en torno a cero sería una correlación aleatoria; un valor negativo sería una tinción segregada y valores positivos implicarían una tinción dependiente (Li et al., 2004).

Para el análisis cuantitativo del grado de correlación de dos tinciones se deben tener en cuenta varios de los métodos, ya que ninguno de ellos es perfecto. De modo que lo mejor es analizar las imágenes mediante diferentes métodos y considerar los resultados en su conjunto.

\section{Análisis mediante citometría de flujo.}

Para determinar el perfil de ciclo de las células, se realizó un análisis del contenido de ADN mediante el marcaje con ioduro de propidio. Tras el tratamiento correspondiente, las células se lavaron varias veces con PBS y se levantaron con Tripsina-EDTA (GIBCO, Invitrogen) cuando fue necesario. Se continuó lavando con PBS varias veces más mediante centrifugaciones de 10 minutos a $1.500 \mathrm{rpm}$ cada una. El pellet se resuspendió en $700 \mu \mathrm{l}$ de etanol al $70 \%$ frío. Una vez que las células fueron fijadas, se lavaron tres veces con PBS y se resuspendieron en la solución de marcaje con ioduro de propidio (5 $\mu \mathrm{g} / \mathrm{ml}$ de ioduro de propidio y $200 \mu \mathrm{g} / \mathrm{ml}$ de ARNasa A en PBS). Las células se incubaron con la solución de marcaje una hora a temperatura ambiente en oscuridad. La adquisición de datos se realizó con el programa Cell Quest (BectonDickinson) y el contenido de ADN de las células se cuantificó utilizando un citómetro FACScalibur (BD Biosciences) y se analizó utilizando la aplicación Modfit $\mathrm{LT}^{\mathrm{TM}}$ (Verity Software House). 


\section{Inmunohistoquímica.}

Las biopsias obtenidas se fijaron en formalina y se embebieron en parafina. A continuación, se realizaron cortes de $3 \mu \mathrm{m}$ de grosor y se transfirieron a portaobjetos de cristal con la superficie cargada positivamente (silanizados). Se secaron durante 16 horas a $56^{\circ} \mathrm{C}$ y se eliminó la parafina (desparafinado). Después, se rehidrataron mediante series de etanol de concentraciones decrecientes y se lavaron con PBS. Para la recuperación de los antígenos, las muestras fueron tratadas con tampón citrato $10 \mathrm{mM}$ pH 6,5 durante 2 minutos en una olla a presión. El marcaje se realizó con el anticuerpo monoclonal 1F6 y el anticuerpo policlonal VC específicos para VRK1. Después de la incubación, la inmunodetección se realizó mediante el método DAKO EnVision Visualization Method (DAKO) con el cromógeno diaminobencidina (DAB) como sustrato que da una tinción de color marrón.

Los cortes de tejido teñidos se analizaron con un microscopio óptico Olympus BX51 y las fotos fueron tomadas con la cámara Olympus DP70 asociada al microscopio.

\section{Cromatografía de exclusión por tamaño.}

La cromatografía de exclusión molecular (denominada también filtración en gel o de tamiz molecular) es una técnica muy sencilla para la separación de proteínas y ácidos nucleicos. En este caso, se utilizó esta técnica para la detección y aislamiento de complejos proteicos. Para ello, se sembraron células HEK293T y 48 horas después se lisaron en un tampón de lisis que contenía $20 \mathrm{mM}$ Tris- $\mathrm{HCl} \mathrm{pH} 7,4,137 \mathrm{mM} \mathrm{NaCl}, 2$ mM EDTA, 25 mM $\beta$-glicerofosfato, 10\% glicerol, 1\% Tritón-X100 con inhibidores de fosfatasas y proteasas ( $1 \mathrm{mM}$ PMSF, $10 \mathrm{mg} / \mathrm{ml}$ aprotinina, $10 \mathrm{mg} / \mathrm{ml}$ leupeptina, $1 \mathrm{mM}$ ortovanadato sódico). El extracto celular se incubó 20 minutos en hielo y, a continuación, se centrifugó a 13.000 rpm durante 20 minutos. Se usaron $3 \mathrm{mg}$ del extracto para el ensayo.

Este tipo de cromatografía se realiza en columnas cilíndricas rellenas de algún gel fabricado para este fin. En este caso, la columna utilizada fue Superose 12, 10/300 GL (GE Healthcare) y los marcadores de Bio-Rad (Tiroglobulina $670 \mathrm{KDa}, \gamma$-globulina $158 \mathrm{KDa}$, ovalbúmina $44 \mathrm{KDa}$, mioglobina $17 \mathrm{KDa}$ y vitamina $\mathrm{B}_{12} 1,35 \mathrm{KDa}$ ).

Se recogieron fracciones de $200 \mu \mathrm{l}$ a un flujo de $0,2 \mathrm{ml} / \mathrm{min}$. Las fracciones se precipitaron mediante tricloroacético y se procesaron para proceder a la electroforesis en geles SDS-PAGE y posterior inmunoblot. 
La cromatografía se llevó a cabo en un módulo de HPLC de la marca HP serie 1100 (Agilent Technologies, Alemania) y el programa ChemStation.

\section{Técnicas proteómicas.}

20.1. Pulldown a gran escala para la purificación e identificación de proteínas asociadas a VRK1.

La línea celular HEK293T fue transfectada con $8 \mu \mathrm{g}$ de pCEFL-GST-VRK1 y $2 \mu \mathrm{g}$ de pCEFL-GST $\varnothing$ como control del ensayo. 48 horas después, se lisaron con un tampón compuesto por $50 \mathrm{mM}$ Tris- $\mathrm{HCl} \mathrm{pH}$ 8,0, $200 \mathrm{mM} \mathrm{NaCl}, 1 \%$ Triton X-100 con inhibidores de fosfatasas y proteasas ( $1 \mathrm{mM}$ PMSF, $10 \mathrm{mg} / \mathrm{ml}$ aprotinina, $10 \mathrm{mg} / \mathrm{ml}$ leupeptina, 1 $\mathrm{mM}$ ortovanadato sódico). Los lisados se incubaron toda la noche con 200-300 $\mu$ de la resina Glutathion Sepharose 4B Beads (Amersham Biosciences, Uppsala, Suecia) a $4^{\circ} \mathrm{C}$ en agitación orbital. Tras este tiempo, se recogió la resina por centrifugación suave y se lavó varias veces con el mismo tampón de lisis. Este precipitado se congeló a $-20^{\circ} \mathrm{C}$ hasta el momento de la electroforesis bidimensional.

\subsection{Electroforesis bidimensional.}

Las proteínas precipitadas con la resina deben eluirse. Para ello, la resina se mezcló con $250 \mu \mathrm{l}$ de tampón de rehidratación [7 M urea, 2 M tiourea, 4\% CHAPS, 1,2\% DeStreak Reagent (GE Healthcare), 50 mM DTT, 5 mM TCEP]. Esta mezcla se agitó con el vórtex y se incubó 30 minutos a $30^{\circ} \mathrm{C}$. Después, se centrifiugó 2 minutos a $15.000 \mathrm{rpm}$. El sobrenadante contiene las proteínas eluidas. A continuación, se llevó a cabo la electroforesis bidimensional.

La primera dimensión se realizó mediante isoelectroenfoque, usando un gradiente de $\mathrm{pH}$ 3-10 o de $\mathrm{pH}$ 4-7 no lineal inmovilizado (tiras IPG). El isoelectroenfoque se realizó del siguiente modo: 12 horas a $50 \mathrm{~V}, 1$ hora a $500 \mathrm{~V}, 1$ hora a $1000 \mathrm{~V}, 30$ minutos con un gradiente de voltaje entre 1000-8000 V y 5 horas hasta que el voltaje alcanzó $35000 \mathrm{~V}$. La segunda dimensión se realizó cargando las tiras de IPG en geles SDS-PAGE al $10 \%$ de acrilamida. Las proteínas fueron detectadas mediante tinción fluorescente con Sypro Ruby Protein Gel Staining (Invitrogen) y se visualizaron mediante un escáner FLA-3000 (Fuji Film). 
20.3. Digestión de los spots, determinación de las masas de los péptidos por MALDI-TOF e identificación con MASCOT.

Las proteínas seleccionadas (spots) se cortaron del gel mediante un sistema robótico Proteineer spll (Bruker-Daltonics) y se digirieron con tripsina. Para ello, los fragmentos obtenidos se lavaron con $25 \mathrm{mM}$ de bicarbonato de amonio y acetonitrilo. Después, fueron tratados con $20 \mathrm{mM}$ DTT en $25 \mathrm{mM}$ de bicarbonato de amonio y con iodoacetamida $100 \mathrm{mM}$ en bicarbonato de amonio $25 \mathrm{mM}$. A continuación, se lavaron con $50 \mathrm{mM}$ de bicarbonato de amonio con acetonitrilo y se dejaron secar. Se añadió tripsina porcina modificada (Promega) en $25 \mathrm{mM}$ de bicarbonato de amonio a una concentración final de $12 \mathrm{ng} / \mu \mathrm{l}$. Se incubó 16 horas a $37^{\circ} \mathrm{C}$. Los péptidos obtenidos se secaron en un sistema de vacío Speed Vacuum System y se resuspendieron con $0,1 \%$ de ácido trifluoroacético y $50 \%$ de acetonitrilo en un volumen final de $5 \mu \mathrm{l}$.

La determinación de las masas de los péptidos se hizo con un espectrómetro Bruker Ultraflex MALDI-TOF (Bruker Daltonics). Para ello, $1 \mu \mathrm{l}$ de la solución de péptidos obtenida se mezcló con $0,5 \mu$ de solución matriz ( $5 \mathrm{~g} / \mathrm{L}$ de ácido 2,5dihidroxibenzoico en $33 \%$ de acetonitrilo acuoso y $0,1 \%$ de ácido trifluoroacético).

Los espectros obtenidos fueron abiertos con el programa Bio Tools 2.1 (Bruker Daltonics) y analizados con el programa Xtof 5.1.1. La lista de masas de picos generadas fueron copiadas al servidor Mascot Server (versión 1.2) (Perkins et al., 1999) y se realizó la búsqueda frente a la base de datos Swiss-Prot (versión 20061011). Los parámetros de búsqueda utilizados establecieron que son significativas $(p<0,05)$ aquellas identificaciones con valores o scores mayores de 54 .

\section{Reactivos.}

Los reactivos utilizados fueron los de las compañias Sigma (Sigma-Aldrich.Inc, St. Louis, MO, USA) o Calbiochem (EMD Biosciences. Inc, La Jolla, CA, USA) salvo que se indique otra casa comercial.

La sincronización de células en cultivo en mitosis se llevó a cabo mediante la adición al medio de cultivo celular de nocodazol a una concentración final de $83 \mathrm{nM}$ durante 15 horas.

El tratamiento de la proteína VCP con el inhibidor NEM se hizo incubando la proteína en un tampón compuesto por $50 \mathrm{mM}$ Tris- $\mathrm{HCl} \mathrm{pH} 8,20 \mathrm{mM} \mathrm{MgCl}, 1 \mathrm{mM}$ EDTA, $1 \mathrm{mM}$ DTT y $3 \mathrm{mM}$ ATP en un volumen final de $50 \mu$ durante 15 minutos a $37^{\circ} \mathrm{C}$. A continuación, se lavó varias veces con PBS y se utilizó así en los ensayos quinasa in vitro. 
El tratamiento con la fosfatasa alcalina CIAP (Roche Diagnostics $\mathrm{GmbH}$, Mannheim, Alemania) se llevó a cabo en el tampón específico suministrado por la casa comercial en un volumen final de $50 \mu$ durante 90 minutos a $30^{\circ} \mathrm{C}$.

\section{Construcciones de ADN recombinante.}

Tabla I. Construcciones de ADN recombinante usadas.

\begin{tabular}{|c|c|c|c|c|}
\hline Construcción & Vector & Inserto & Uso & Procedencia \\
\hline GST-VRK1 & pGEX-4T1 & VRK1 & $\begin{array}{l}\text { expresión de } \\
\text { proteína de fusión } \\
\text { con GST en } E \text {. coli }\end{array}$ & Laboratorio \\
\hline GST-VRK1 ${ }^{\mathrm{K} 179 \mathrm{E}}$ & pGEX-4T1 & VRK $1^{\mathrm{K} 179 \mathrm{E}}$ & $\begin{array}{l}\text { expresión de } \\
\text { proteína de fusión } \\
\text { con GST en E. coli }\end{array}$ & Laboratorio \\
\hline GST-VRK2A ${ }^{\mathrm{K} 169 \mathrm{E}}$ & pGEX-4T1 & VRK2A ${ }^{\mathrm{K} 169 \mathrm{E}}$ & $\begin{array}{l}\text { expresión de } \\
\text { proteína de fusión } \\
\text { con GST en } E \text {. coli }\end{array}$ & Laboratorio \\
\hline GST-VRK2B $^{\mathrm{K} 169 \mathrm{E}}$ & pGEX-4T1 & VRK2B ${ }^{\mathrm{K} 169 \mathrm{E}}$ & $\begin{array}{l}\text { expresión de } \\
\text { proteína de fusión } \\
\text { con GST en } E \text {. coli }\end{array}$ & Laboratorio \\
\hline VRK3-His & pET23A & VRK3 & $\begin{array}{l}\text { expresión de } \\
\text { proteína de fusión } \\
\text { con } 6 \text { xHis en } E \text {. coli }\end{array}$ & Laboratorio \\
\hline VRK1-His & pET23A & VRK1 & $\begin{array}{l}\text { expresión de } \\
\text { proteína de fusión } \\
\text { con } 6 x H i s \text { en } E \text {. coli }\end{array}$ & Laboratorio \\
\hline pCEFL-HA-VRK1 & pCEFL-HA & VRK1 & $\begin{array}{l}\text { expresión eucariota } \\
\text { con epítopo HA }\end{array}$ & Laboratorio \\
\hline $\begin{array}{l}\text { pCEFL-HA- } \\
\text { VRK1 }{ }^{1179 E}\end{array}$ & pCEFL-HA & VRK $1^{\mathrm{K} 179 \mathrm{E}}$ & $\begin{array}{l}\text { expresión eucariota } \\
\text { con epítopo HA }\end{array}$ & Laboratorio \\
\hline $\begin{array}{l}\text { pCDNA3.1-VRK1- } \\
\text { MYC }\end{array}$ & pCDNA3.1-MYC & VRK1 & $\begin{array}{l}\text { expresión eucariota } \\
\text { con epítopo MYC }\end{array}$ & Laboratorio \\
\hline $\begin{array}{l}\text { pCDNA3.1- } \\
\text { VRK1(NL)-MYC }\end{array}$ & pCDNA3.1-MYC & VRK1 (aa 1-332) & $\begin{array}{l}\text { expresión eucariota } \\
\text { con epítopo MYC }\end{array}$ & Laboratorio \\
\hline $\begin{array}{l}\text { pCDNA3.1- } \\
\text { VRK1(Nc)-MYC }\end{array}$ & pCDNA3.1-MYC & VRK1 (aa 1-267) & $\begin{array}{l}\text { expresión eucariota } \\
\text { con epítopo MYC }\end{array}$ & Laboratorio \\
\hline pCEFL-GST-VRK1 & pCEFL-GST & VRK1 & $\begin{array}{l}\text { expresión eucariota } \\
\text { con epítopo GST }\end{array}$ & Laboratorio \\
\hline pCEFL-GST-VRK1-C & pCEFL-GST & VRK1 (aa 267-396) & $\begin{array}{l}\text { expresión eucariota } \\
\text { con epítopo GST }\end{array}$ & Laboratorio \\
\hline$\underset{\Delta 32-51}{p F c-M E K 1^{S 218 / 222 E},}$ & $\mathrm{pFc}-\mathrm{CMV}$ & MEK1 ${ }^{\text {S218/222E, } \Delta 32-51}$ & expresión eucariota & Stratagene \\
\hline
\end{tabular}


Tabla I. (continuación).

\begin{tabular}{|c|c|c|c|c|}
\hline Construcción & Vector & Inserto & Uso & Procedencia \\
\hline pCEFL-HA-MEK1 & pCEFL-HA & MEK1 & $\begin{array}{c}\text { expresión eucariota } \\
\text { con epítopo HA }\end{array}$ & Laboratorio \\
\hline pRc-PIk1 ${ }^{T 210 D}-M Y C$ & pRc-CMV-MYC & $\mathrm{Plk} 1^{\mathrm{T} 210 \mathrm{D}}$ & $\begin{array}{c}\text { expresión eucariota } \\
\text { con epítopo MYC }\end{array}$ & Erich A. Nigg \\
\hline pSUPER-siVRK1 & pSUPER & VRK1 ARNi (64bp) & sistema ARNi & Laboratorio \\
\hline pCEFL-HA-PIk3 & pCEFL-HA & Plk3 & $\begin{array}{c}\text { expresión eucariota } \\
\text { con epítopo HA }\end{array}$ & Laboratorio \\
\hline pCEFL-HA-PIk $3^{K 52 R}$ & pCEFL-HA & $\mathrm{Plk}^{\mathrm{K} 52 \mathrm{R}}$ & $\begin{array}{c}\text { expresión eucariota } \\
\text { con epítopo HA }\end{array}$ & Laboratorio \\
\hline GST-VCP & pGEX-4T1 & VCP & $\begin{array}{c}\text { expresión de proteína } \\
\text { de fusión con GST en } \\
\text { E. coli }\end{array}$ & Laboratorio \\
\hline pCEFL-GST-VCP & pCEFL-GST & VCP & $\begin{array}{l}\text { expresión eucariota } \\
\text { con epítopo GST }\end{array}$ & Laboratorio \\
\hline pCEFL-AU5-VCP & pCEFL-AU5 & VCP & $\begin{array}{c}\text { expresión eucariota } \\
\text { con epítopo AU5 }\end{array}$ & Laboratorio \\
\hline p47-His & pET23 & $\mathrm{p} 47$ & $\begin{array}{l}\text { expresión de proteína } \\
\text { de fusión con } 6 \times \text { His } \\
\text { en } E \text {. coli }\end{array}$ & Meyer HH \\
\hline
\end{tabular}

Tabla II. Mutaciones puntuales generadas.

\begin{tabular}{|lcc|}
\hline Contrucción & Mutación & Vectores \\
\hline \hline VRK1 $^{\text {S342A }}$ & 342 (Ser-Ala) & pCEFL-HA \\
VRK1 $^{\text {K179E/S342A }}$ & 342 (Ser-Ala) & pGEX-4T-GST \\
VRK1 $^{\text {S342D }}$ & 342 (Ser-Asp) & pCEFL-HA \\
\hline
\end{tabular}


Tabla III. Construcciones de ADN recombinante generadas

\begin{tabular}{|c|c|c|c|c|}
\hline Contrucción & Vector & Inserto & $\begin{array}{l}\text { Enzimas de } \\
\text { restricción }\end{array}$ & Origen \\
\hline pCEFL-HA-PIk3 & $\begin{array}{c}\text { pCEFL- } \\
\text { HA }\end{array}$ & Plk3 & EcoRI-Notl & pCR253-Plk3 (W. Dai) \\
\hline $\begin{array}{l}\text { pCEFL-HA- } \\
\text { PIk3 }{ }^{\text {K52R }}\end{array}$ & $\begin{array}{c}\text { pCEFL- } \\
\text { HA }\end{array}$ & $\mathrm{Plk} 3^{\mathrm{K} 52 \mathrm{R}}$ & EcoRI-Notl & $\begin{array}{l}\text { pCR253-PIk3(K52R) } \\
\text { (W. Dai) }\end{array}$ \\
\hline $\begin{array}{l}\text { pCEFL-FLAG- } \\
\text { Plk3 }\end{array}$ & $\begin{array}{l}\text { pCEFL- } \\
\text { FLAG }\end{array}$ & Plk3 & EcoRI-Notl & $\begin{array}{l}\text { pCR253-Plk3 } \\
\text { (W. Dai) }\end{array}$ \\
\hline $\begin{array}{l}\text { pCEFL-FLAG- } \\
\text { Plk3 }{ }^{\text {K52R }}\end{array}$ & $\begin{array}{l}\text { pCEFL- } \\
\text { FLAG }\end{array}$ & $P I k 3^{K 52 R}$ & EcoRI-Notl & $\begin{array}{l}\text { pCR253-PIk3(K52R) } \\
\text { (W. Dai) }\end{array}$ \\
\hline $\begin{array}{l}\text { pCEFL-GST- } \\
\text { PIk3 }\end{array}$ & $\begin{array}{l}\text { pCEFL- } \\
\text { GST }\end{array}$ & Plk3 & EcoRI-Notl & pCR253-Plk3 (W. Dai) \\
\hline $\begin{array}{l}\text { pCEFL-GST- } \\
\text { PIk3 }{ }^{\text {K52R }}\end{array}$ & $\begin{array}{l}\text { pCEFL- } \\
\text { GST }\end{array}$ & $\mathrm{Plk}^{\mathrm{K} 52 \mathrm{R}}$ & EcoRI-Notl & $\begin{array}{l}\text { pCR253-Plk3(K52R) } \\
\text { (W. Dai) }\end{array}$ \\
\hline $\begin{array}{l}\text { pCEFL-AU5- } \\
\text { PIk3 }\end{array}$ & $\begin{array}{l}\text { pCEFL- } \\
\text { AU5 }\end{array}$ & Plk3 & EcoRI-Notl & pCR253-Plk3 (W. Dai) \\
\hline $\begin{array}{l}\text { PCEFL-GST- } \\
\text { VRK1 }{ }^{\text {K179E }}\end{array}$ & $\begin{array}{l}\text { pCEFL- } \\
\text { GST }\end{array}$ & VRK1 $1^{\text {K179E }}$ & BamHI-Notl & $\begin{array}{l}\text { Por PCR desde ADNc (ver } \\
\text { oligonucleótidos) }\end{array}$ \\
\hline GST-VCP & $\begin{array}{l}\text { pGEX- } \\
4 \mathrm{~T} 1\end{array}$ & VCP & BamHI/Notl & $\begin{array}{l}\text { Por PCR desde ADNc (ver } \\
\text { oligonucleótidos) }\end{array}$ \\
\hline $\begin{array}{l}\text { pCEFL-AU5- } \\
\text { VCP }\end{array}$ & $\begin{array}{l}\text { pCEFL- } \\
\text { AU5 }\end{array}$ & VCP & BamHI/Notl & $\begin{array}{l}\text { Por PCR desde ADNc (ver } \\
\text { oligonucleótidos) }\end{array}$ \\
\hline $\begin{array}{l}\text { pCEFL-GST- } \\
\text { VCP }\end{array}$ & $\begin{array}{l}\text { pCEFL- } \\
\text { GST }\end{array}$ & VCP & BamHI/Notl & $\begin{array}{l}\text { Por PCR desde ADNc (ver } \\
\text { oligonucleótidos) }\end{array}$ \\
\hline
\end{tabular}




\section{Anticuerpos primarios.}

Tabla IV. Anticuerpos primarios.

\begin{tabular}{|c|c|c|c|c|}
\hline Nombre & Antígeno & Tipo & Dilución de uso & Procedencia \\
\hline VC & $\begin{array}{c}\text { VRK1 } \\
\text { (aa 267-396) }\end{array}$ & policlonal conejo & $\begin{array}{l}\text { IB: 1:2000; IF: 1:200 } \\
\text { IP: 1:100 }\end{array}$ & producción propia \\
\hline VE1 & $\begin{array}{l}\text { VRK1 } \\
\text { completa }\end{array}$ & policlonal conejo & $\begin{array}{l}\text { IB: 1:2000; IF: 1:200 } \\
\text { IP: 1:100 }\end{array}$ & producción propia \\
\hline H1 & $\begin{array}{l}\text { VRK1 } \\
\text { completa }\end{array}$ & policlonal conejo & $\begin{array}{c}\text { IB: 1:1000; IF: 1:100 } \\
\text { IP: 1:100 }\end{array}$ & producción propia \\
\hline $1 \mathrm{~F} 6$ & $\begin{array}{c}\text { VRK1 } \\
\text { (aa 333-396) }\end{array}$ & monoclonal ratón & $\begin{array}{l}\text { IB: 1:20000; IF: } \\
\text { 1:2000; IP: 1:500 }\end{array}$ & producción propia \\
\hline$\beta$-actina (AC-15) & $\beta$-actina & IgG1 monoclonal ratón & IB: 1:5000 & Sigma \\
\hline anti-HA (HA.11) & epítopo HA & lgG1 monoclonal ratón & $\begin{array}{c}\text { IB: 1:1000; IF: 1:100; } \\
\text { IF: 1:100 }\end{array}$ & Covance \\
\hline anti-HA & epítopo HA & IgG policlonal conejo & $\begin{array}{c}\text { IB: 1:1000; IF: 1:100; } \\
\text { IF: 1:100 }\end{array}$ & eBioscience \\
\hline anti-MYC & epítopo MYC & IgG policlonal conejo & $\begin{array}{c}\text { IB: 1:2000; IF: 1:500; } \\
\text { IF: 1:150 }\end{array}$ & Upstate \\
\hline anti-FLAG & $\begin{array}{l}\text { epítopo } \\
\text { FLAG }\end{array}$ & IgG policlonal conejo & $\begin{array}{c}\text { IB: 1:1000; IF: 1:100; } \\
\text { IF: } 1: 100\end{array}$ & Sigma \\
\hline anti-FLAG & $\begin{array}{l}\text { epítopo } \\
\text { FLAG }\end{array}$ & IgG1 monoclonal ratón & $\begin{array}{c}\text { IB: 1:1000; IF: 1:100; } \\
\text { IF: 1:100 }\end{array}$ & Sigma \\
\hline anti-AU5 & epítopo AU5 & lgG1 monoclonal ratón & $\begin{array}{l}\text { IB: 1:1000; } \\
\text { IF: 1:100 }\end{array}$ & Covance \\
\hline CNK & Plk3 & IgG policlonal conejo & IB: 1:500 & Proteintech Group \\
\hline Giantin & $\begin{array}{l}\text { Giantina } \\
\text { (aa 1-469) }\end{array}$ & policlonal conejo & IF: 1:1000 & Covance \\
\hline GM130 & GM130 & lgG1 monoclonal ratón & $\begin{array}{l}\text { IB: 1:1000; } \\
\text { IF: 1:100 }\end{array}$ & BD Transduction \\
\hline anti-GST (B-14) & epítopo GST & monoclonal ratón & IB: 1:1000; IP: 1:100 & Santa Cruz \\
\hline $\begin{array}{l}58 \mathrm{~K} \text { Golgi } \\
\text { protein }\end{array}$ & $58 \mathrm{~K}$ & IgG1 monoclonal ratón & IB: 1:1000 & Abcam \\
\hline PRK & Plk3 & IgG1 monoclonal ratón & IB: 1:500 & BD Pharmingen \\
\hline Calreticulina & $\begin{array}{l}\text { Calreticulina } \\
\text { (aa 405-417) }\end{array}$ & IgG policlonal conejo & IF: $1: 100$ & Calbiochem \\
\hline pMEK1 & $\begin{array}{c}\text { pSer217/221 } \\
\text { de MEK1/2 }\end{array}$ & policlonal conejo & IB: 1:1000 & Cell Signaling \\
\hline MEK1 & $\begin{array}{l}\text { C-terminal } \\
\text { MEK1 }\end{array}$ & policlonal conejo & IB: 1:1000 & Santa Cruz \\
\hline VCP & $\begin{array}{c}\text { VCP } \\
\text { (aa 687-806) }\end{array}$ & policlonal conejo & IB: 1:1000 & Santa Cruz \\
\hline
\end{tabular}




\section{Oligonucleótidos.}

Tabla V. Oligonucleótidos.

\begin{tabular}{|c|c|c|}
\hline Nombre & Secuencia & Uso \\
\hline VRK1 (S342A)-S & 5'-GGCAAATTGGACCTCGCTGTTGTGGAGAATG-3' & mutagénesis sitio Plk \\
\hline VRK1 (S342A)-AS & 5'-CATTCTCCACAACAGCGAGGTCCAATTTGCC-3' & mutagénesis sitio Plk \\
\hline VRK1(S342D)-S & 5'-GGCAAATTGGACCTCGATGTTGTGGAGAATG-3' & mutagénesis sitio Plk \\
\hline VRK1(S342D)-AS & 5'-САTTCTCCACAACATCGAGGTCCAATTTGCC-3' & mutagénesis sitio Plk \\
\hline $\begin{array}{l}\text { siVRK1-02 S } \\
\text { (Dharmacon) }\end{array}$ & 5'-CAAGGAACCUGGUGUUGAAUU-3' & $\begin{array}{l}\text { ARNi silenciamiento de } \\
\text { VRK1 humana }\end{array}$ \\
\hline $\begin{array}{l}\text { siVRK1-02 A } \\
\text { (Dharmacon) }\end{array}$ & 5'-UUCAACACCAGGUUCCUUGUU-3' & $\begin{array}{l}\text { ARNi silenciamiento de } \\
\text { VRK1 humana }\end{array}$ \\
\hline VR1 & $\begin{array}{c}\text { CCCGGATCCATGCCTCGTGTAAAAGCAAGCTCAAGCTA } \\
\text { Sitio restricción BamHI }\end{array}$ & $\begin{array}{l}\text { clonación de VRK1 } 1^{\mathrm{K} 179 \mathrm{E}} \\
\text { en pCEFL-GST. }\end{array}$ \\
\hline V1-Notl-3' & $\begin{array}{c}\text { GGGGCGGCCGCTTACTTCTGGACTCTCTTTCTGGTTCTT } \\
\text { Sitio restricción Notl }\end{array}$ & $\begin{array}{l}\text { clonación de VRK1 } 1^{\text {K179E }} \\
\text { en pCEFL-GST }\end{array}$ \\
\hline siVRK1-fwd & $\begin{array}{l}\text { 5'-GATCCCCGAAAGAGAGTCCAGAAGTATTCAAGAGA } \\
\text { TACTTCTGGACTCTCTTTCTTT-3' }\end{array}$ & $\begin{array}{l}\text { oligo para sistema } \\
\text { pSUPER }\end{array}$ \\
\hline siVRK1-rev & $\begin{array}{c}\text { 5'-AGCTTAAAAAGAAAGAGAGTCCAGAAGTATCTCTTGA } \\
\text { ATACTTCTGGACTCTCTTTCGGG-3' }\end{array}$ & $\begin{array}{l}\text { oligo para sistema } \\
\text { pSUPER }\end{array}$ \\
\hline VCP-BamHI & $\begin{array}{c}\text { 5'-CCCGGATCCATGGCTTCTGGAGCCGATTCAAAAGGT- } \\
3^{\prime} \\
\text { Sitio restricción BamHI }\end{array}$ & clonación de VCP \\
\hline VCP-Notl & $\begin{array}{c}\text { 5'-CACGCGGCCGCTTAGCCATACAGGTCATCATCATTG- } \\
3^{\prime} \\
\text { Sitio restricción Notl }\end{array}$ & clonación de VCP \\
\hline
\end{tabular}




\section{Líneas celulares.}

Tabla VI. Líneas celulares.

\begin{tabular}{|c|c|c|c|c|}
\hline Nombre & Organismo & $\begin{array}{c}\text { Tejido de } \\
\text { procedencia }\end{array}$ & $\begin{array}{c}\text { Características } \\
\text { principales }\end{array}$ & Propagación \\
\hline A549 & Humano & $\begin{array}{l}\text { Carcinoma de } \\
\text { pulmón }\end{array}$ & $\begin{array}{l}\text { Expresión normal de } \\
\text { p53 }\end{array}$ & $\begin{array}{c}\text { RPMI } 1640+10 \% \\
\text { FBS }\end{array}$ \\
\hline Cos1 & $\begin{array}{l}\text { Mono verde } \\
\text { (Cercopithecus } \\
\text { aethiops) }\end{array}$ & Fibroblastos de riñón & $\begin{array}{l}\text { Transformadas por } \\
\text { virus SV40 }\end{array}$ & DMEM + $10 \%$ FBS \\
\hline HeLa & Humano & $\begin{array}{l}\text { Adenocarcinoma de } \\
\text { cérvix }\end{array}$ & $\begin{array}{c}\text { Transformadas por } \\
\text { papillomavirus HPV- } \\
18\end{array}$ & DMEM + 10\% FBS \\
\hline MCF-7 & Humano & $\begin{array}{l}\text { Adenocarcinoma de } \\
\text { mama }\end{array}$ & $\begin{array}{l}\text { Expresión normal de } \\
\text { p53 silvestre }\end{array}$ & $\begin{array}{c}\text { RMPI } 1640+10 \% \\
\text { FBS }\end{array}$ \\
\hline HEK293T & Humano & Carcinoma de riñón & $\begin{array}{l}\text { Expresión normal de } \\
\text { p53 silvestre }\end{array}$ & DMEM + $10 \%$ FBS \\
\hline NCl-H1299 & Humano & $\begin{array}{l}\text { Cáncer de pulmón } \\
\text { de célula no } \\
\text { pequeña }\end{array}$ & $\begin{array}{c}\text { Deleción de } \\
\text { homocigosis de p53. } \\
\text { No expresión de p53 }\end{array}$ & $\begin{array}{c}\text { RMPI } 1640+10 \% \\
\text { FBS }\end{array}$ \\
\hline U-2OS & Humano & Osteosarcoma & $\begin{array}{l}\text { Expresión silvestre } \\
\text { de p53. Carencia de } \\
\text { p16 }\end{array}$ & DMEM + 10\% FBS \\
\hline Jurkat & Humano & $\begin{array}{c}\text { Leucemia linfoide T } \\
\text { aguda }\end{array}$ & & $\begin{array}{c}\text { RMPI } 1640+10 \% \\
\text { FBS }\end{array}$ \\
\hline WS1 & Humano & Fibroblasto de piel & Fibroblasto normal & DMEM + $10 \%$ FBS \\
\hline
\end{tabular}





\section{Abreviaturas.}

aa: aminoácidos

ADN: Ácido DesoxirriboNucleico

ADNc: ADN complementario

AG: aparato de Golgi

AMP: Adenosine MonoPhosphate

AO: ácido okadaico

ARF-1: ADP-Ribosylation Factor-1

ARN: Ácido RiboNucleico

ARNi: ARN de interferencia

ARNm: ARN mensajero

Asin.: asincrónicas

ATF-2: Activating Transcription Factor-2

ATM: Atexia-Telangiectasia Mutated protein

ATP: Adenosine TriPhosphate

ATR: ATM and Rad3-related

BAB: motivo básico-ácido-básico

BAF: Barrier to Autointegration Factor

BFA: Befreldina A

BRCA1: BReast CAncer 1

BSA: Bovine Serum Albumin

CaMK-IV: CalModulin Kinase IV

CIAP: Calf Intestinal Alkaline Phosphatase

Chk: Checkpoint kinase

CKI: Casein Kinase I

Cdc2: Cell division control protein 2

CDK: Cyclin Dependent Kinase

COP: Coat Protein

CPC: Chromosomal Passenger Complex

CREB: cAMP-Response Element-Binding

CtBP3/BARS: C-terminal binding protein 3/BFA adenosine diphosphate-ribosylated substrate

DAPI: 4',6'-DiAmidino-2-Phenil Indol

DMEM: Dubelco's modified-Minimum Essential Medium

DNA-PK: DNA-dependent Protein Kinase 
DTT: Ditiotreitol

EDTA: EthyleneDiamine-Tetraacetic Acid

EGF: Epidermal Growth Factor

ELM: Eukaryotic Linear Motif

$E Q$ : ensayo quinasa

EST: Expressed Sequence Tag

ER: Estrogen Receptor

ERAD: Endoplasmatic Reticulum Associated Degradation

ERK: Extracelular signal-Related Kinase

FBS: Fetal Bovine Serum

FHA: Forkhead-Associated

gcd: germ cell deficient

GEF: Guanine nucleotide Exchange Factor

GFP: Green Fluorescent Protein

GTP: Guanosine TriPhosphate

GRASP: Golgi ReAssembly Stacking Protein

GST: Glutatión-S-Transferasa

h: hora

HIF-1 $\alpha$ : Hipoxia Inducible Factor $1 \alpha$

IB: inmunoblot o western blot

IF: inmunofluorescencia

IP: inmunoprecipitación

IPG: Immobilized pH Gradient"

IPTG: IsoPropil- $\beta-D$-TioGalactopiranósido

IR: radiación ionizante

Iк-B $\alpha$ : NF-KB inhibitor

JIP1: JNK Interacting Protein 1

JNK: c-Jun N-terminal Kinase

KDa: Kilodalton

LB: medio de cultivo Luria bertani

M: molar

MALDI-TOF: Matrix-Assisted Laser Desorption/lonization Time-Of-Fligth

MAP: Mitogen-Activated Protein

MAPK: Mitogen-Activated Protein Kinase

MEK1: MAP kinase/ERK kinase 1 
Mdm2: Mouse double minute-2

mg: miligramo

$\mathrm{ml}$ : mililitro

$\mathrm{mm}$ : milímetro

mM: milimolar

MMS: Metil Metano Sulfonato

$\mathrm{m} / \mathrm{z}$ : relación masa carga

min.: minuto

NEM: N-ethylameimide

NES: Nuclear Export Signal

NF-кB: Nuclear transcription factor-kappaB

ng: nanogramo

NHK-1: Nucleosomal Histone Kinase 1

NLS: Nuclear Localization Signal

$\mathrm{nM}$ : nanomolar

$\mathrm{nm}$ : nanometro

nmol: nanomol

Noc.: nocodazol

NRK: Normal Rat Kidney

NSF: N-ethylameimide-Sensitive Factor

MST1: Mammalian STerile20-like 1

NT: no transfectado

PBS: Phosphate Buffer Salinum

PBD: Polo Box Domain

PCR: Polimerase Chain Reaction

PD: pulldown

PKA: Protein Kinase $A$

PKD: Protein Kinase $D$

Plk: Polo like kinase

PMSF: Phenyl Methyl Sulfonyl Phluoride

pog: proliferation of germ cell

PP2A: Protein Phosphatase $2^{a}$

Prk: Proliferation related kinase

PVDF: PolyVinyliDene Fluoride

Ran: Ras-related nuclear 
Rb: Retinoblatome protein

$\mathrm{RE}$ : retículo endoplasmático

ROS: Reactive Oxygen Species

RPLC: Reverse-Phase Liquid Chromatography

RPMI: medio de cultivo desarrollado en el Roswell Park Memorial Institute

rpm: revoluciones por minuto

RTKG: Raf Kinase Trapping to Golgi

RT-PCR: Reverse Transcriptase PCR

SH2: Src Homology 2

SDS: Sodium Dodecyl Sulfate

SDS-PAGE: SDS-Polyacrilamide Gel Electrophoresis

SMA-PCH: Spinal Muscular Atrophy with PontoCerebellar Hypoplasia

SNARE: Soluble NSF Attachment protein Receptor

SUMO: Small Ubiquitin-related MOdifier

TAE: Tris-Acetato-EDTA

UBA: Ubiquitin-Associated domain

UV: radiación Ultravioleta

V: voltio

VCIP135: VCP [p97]/p47 Complex Interacting Protein, p135

VCP: Valosin-Containing Protein

VHR: Vaccinia H1 Related

VRK: Vaccinia Related Kinase

WRN: Werner's syndrome

YSK1: Yeast Sps1/Ste20-related Kinase 1

$\mu \mathrm{Ci}$ : microcurio

$\mu \mathrm{g}:$ microgramo

$\mu \mathrm{l}$ : microlitro

$\mu \mathrm{m}$ : micrómetro

$\mu \mathrm{M}$ : micromolar

${ }^{\circ} \mathrm{C}$ : grado centígrado

Bases Nitrogenadas.

$\begin{array}{llll}\text { A } & \text { adenina } & \text { C } & \text { citosina } \\ \mathrm{U} & \text { uracilo } & \mathrm{G} & \text { guanina } \\ \mathrm{T} & \text { timidina } & & \end{array}$




\section{Aminoácidos.}

\begin{tabular}{|c|c|c|c|c|c|}
\hline alanina & Ala & A & Isoleucina & Ile & I \\
\hline arginina & Arg & $\mathrm{R}$ & Leucina & Leu & L \\
\hline asparragina & Asn & $\mathrm{N}$ & Lisina & Lys & $\mathrm{K}$ \\
\hline ácido aspártico & Asp & $\mathrm{D}$ & Metionina & Met & $M$ \\
\hline cisteína & Cys & C & Prolina & Pro & $\mathrm{P}$ \\
\hline fenilalanina & Phe & $\mathrm{F}$ & Serina & Ser & $S$ \\
\hline glicina & Gly & $G$ & Tirosina & Tyr & $Y$ \\
\hline glutamina & GIn & $Q$ & Treonina & Thr & $\mathrm{T}$ \\
\hline ácido glutámico & Glu & $E$ & Triptófano & Try & W \\
\hline histidina & His & $\mathrm{H}$ & valina & Val & $\mathrm{V}$ \\
\hline
\end{tabular}



Bibliografía 

Acharya, U., Jacobs, R., Peters, J.M., Watson, N., Farquhar, M.G., and Malhotra, V. (1995). The formation of Golgi stacks from vesiculated Golgi membranes requires two distinct fusion events. Cell 82, 895-904.

Acharya, U., Mallabiabarrena, A., Acharya, J.K., and Malhotra, V. (1998). Signaling via mitogen-activated protein kinase kinase (MEK1) is required for Golgi fragmentation during mitosis. Cell 92, 183-192.

Adams, R.R., Carmena, M., and Earnshaw, W.C. (2001). Chromosomal passengers and the (aurora) ABCs of mitosis. Trends in cell biology 11, 49-54.

Aebersold, D.M., Shaul, Y.D., Yung, Y., Yarom, N., Yao, Z., Hanoch, T., and Seger, R. (2004). Extracellular signal-regulated kinase 1c (ERK1c), a novel 42-kilodalton ERK, demonstrates unique modes of regulation, localization, and function. Molecular and cellular biology $24,10000-10015$.

Agoulnik, A.I., Lu, B., Zhu, Q., Truong, C., Ty, M.T., Arango, N., Chada, K.K., and Bishop, C.E. (2002). A novel gene, Pog, is necessary for primordial germ cell proliferation in the mouse and underlies the germ cell deficient mutation, gcd. Human molecular genetics 11, 3047-3053.

Aihara, H., Nakagawa, T., Yasui, K., Ohta, T., Hirose, S., Dhomae, N., Takio, K., Kaneko, M., Takeshima, Y., Muramatsu, M., and Ito, T. (2004). Nucleosomal histone kinase-1 phosphorylates H2A Thr 119 during mitosis in the early Drosophila embryo. Genes \& development 18, 877-888.

Alessi, D.R., Cuenda, A., Cohen, P., Dudley, D.T., and Saltiel, A.R. (1995). PD 098059 is a specific inhibitor of the activation of mitogen-activated protein kinase kinase in vitro and in vivo. The Journal of biological chemistry $270,27489-27494$.

Altan-Bonnet, N., Phair, R.D., Polishchuk, R.S., Weigert, R., and Lippincott-Schwartz, J. (2003). A role for Arf1 in mitotic Golgi disassembly, chromosome segregation, and cytokinesis. Proceedings of the National Academy of Sciences of the United States of America 100, 13314-13319.

Altan-Bonnet, N., Sougrat, R., Liu, W., Snapp, E.L., Ward, T., and Lippincott-Schwartz, J. (2006). Golgi inheritance in mammalian cells is mediated through endoplasmic reticulum export activities. Molecular biology of the cell 17, 990-1005.

Anckar, J., and Sistonen, L. (2007). SUMO: getting it on. Biochemical Society transactions 35, 1409-1413.

Andersen, J.S., Lam, Y.W., Leung, A.K., Ong, S.E., Lyon, C.E., Lamond, A.I., and Mann, M. (2005). Nucleolar proteome dynamics. Nature 433, 77-83.

Ando, K., Ozaki, T., Yamamoto, H., Furuya, K., Hosoda, M., Hayashi, S., Fukuzawa, M., and Nakagawara, A. (2004). Polo-like kinase 1 (Plk1) inhibits p53 function by physical interaction and phosphorylation. The Journal of biological chemistry 279, 25549-25561.

Anger, M., Kues, W.A., Klima, J., Mielenz, M., Kubelka, M., Motlik, J., Esner, M., Dvorak, P., Carnwath, J.W., and Niemann, H. (2003). Cell cycle dependent expression of Plk1 in synchronized porcine fetal fibroblasts. Mol Reprod Dev 65, 245-253. 
Axelsson, M.A., and Warren, G. (2004). Rapid, endoplasmic reticulum-independent diffusion of the mitotic Golgi haze. Molecular biology of the cell 15, 1843-1852.

Bahassi el, M., Conn, C.W., Myer, D.L., Hennigan, R.F., McGowan, C.H., Sanchez, Y., and Stambrook, P.J. (2002). Mammalian Polo-like kinase 3 (PIk3) is a multifunctional protein involved in stress response pathways. Oncogene 21, 6633-6640.

Bahassi el, M., Hennigan, R.F., Myer, D.L., and Stambrook, P.J. (2004). Cdc25C phosphorylation on serine 191 by Plk3 promotes its nuclear translocation. Oncogene 23, 2658-2663.

Bahassi el, M., Myer, D.L., McKenney, R.J., Hennigan, R.F., and Stambrook, P.J. (2006). Priming phosphorylation of Chk2 by polo-like kinase 3 (Plk3) mediates its full activation by ATM and a downstream checkpoint in response to DNA damage. Mutat Res 596, 166-176.

Balch, W.E., Dunphy, W.G., Braell, W.A., and Rothman, J.E. (1984). Reconstitution of the transport of protein between successive compartments of the Golgi measured by the coupled incorporation of $\mathrm{N}$-acetylglucosamine. Cell 39, 405-416.

Banham, A.H., and Smith, G.L. (1992). Vaccinia virus gene B1R encodes a 34-kDa serine/threonine protein kinase that localizes in cytoplasmic factories and is packaged into virions. Virology 191, 803-812.

Barcia, R., Lopez-Borges, S., Vega, F.M., and Lazo, P.A. (2002). Kinetic properties of p53 phosphorylation by the human vaccinia-related kinase 1 . Archives of biochemistry and biophysics 399, 1-5.

Barr, F.A. (2004). Golgi inheritance: shaken but not stirred. The Journal of cell biology 164, 955-958.

Barr, F.A., Puype, M., Vandekerckhove, J., and Warren, G. (1997). GRASP65, a protein involved in the stacking of Golgi cisternae. Cell 91, 253-262.

Barr, F.A., Sillje, H.H., and Nigg, E.A. (2004). Polo-like kinases and the orchestration of cell division. Nat Rev Mol Cell Biol 5, 429-440.

Bartz, R., Sun, L.P., Bisel, B., Wei, J.H., and Seemann, J. (2008). Spatial separation of Golgi and ER during mitosis protects SREBP from unregulated activation. The EMBO journal 27, 948-955.

Bateman, A., Birney, E., Cerruti, L., Durbin, R., Etwiller, L., Eddy, S.R., Griffiths-Jones, S., Howe, K.L., Marshall, M., and Sonnhammer, E.L. (2002). The Pfam protein families database. Nucleic acids research 30, 276-280.

Berger, S.L. (2007). The complex language of chromatin regulation during transcription. Nature 447, 407-412.

Birnboim, H.C., and Doly, J. (1979). A rapid alkaline extraction procedure for screening recombinant plasmid DNA. Nucleic acids research 7, 1513-1523.

Bisel, B., Wang, Y., Wei, J.H., Xiang, Y., Tang, D., Miron-Mendoza, M., Yoshimura, S., Nakamura, N., and Seemann, J. (2008). ERK regulates Golgi and centrosome 
orientation towards the leading edge through GRASP65. The Journal of cell biology 182, 837-843.

Blanco, S., Klimcakova, L., Vega, F.M., and Lazo, P.A. (2006). The subcellular localization of vaccinia-related kinase-2 (VRK2) isoforms determines their different effect on p53 stability in tumour cell lines. The FEBS journal 273, 2487-2504.

Blanco, S., Santos, C., and Lazo, P.A. (2007). Vaccinia-related kinase 2 modulates the stress response to hypoxia mediated by TAK1. Molecular and cellular biology 27, 72737283.

Blanco, S., Sanz-Garcia, M., Santos, C.R., and Lazo, P.A. (2008). Modulation of interleukin-1 transcriptional response by the interaction between VRK2 and the JIP1 scaffold protein. PloS one 3, e1660.

Boudeau, J., Miranda-Saavedra, D., Barton, G.J., and Alessi, D.R. (2006). Emerging roles of pseudokinases. Trends in cell biology 16, 443-452.

Boyd, J.M., Subramanian, T., Schaeper, U., La Regina, M., Bayley, S., and Chinnadurai, G. (1993). A region in the C-terminus of adenovirus 2/5 E1a protein is required for association with a cellular phosphoprotein and important for the negative modulation of T24-ras mediated transformation, tumorigenesis and metastasis. The EMBO journal 12, 469-478.

Boyle, K.A., and Traktman, P. (2004). Members of a novel family of mammalian protein kinases complement the DNA-negative phenotype of a vaccinia virus ts mutant defective in the B1 kinase. Journal of virology 78, 1992-2005.

Bruderer, R.M., Brasseur, C., and Meyer, H.H. (2004). The AAA ATPase p97NCP interacts with its alternative co-factors, Ufd1-Npl4 and p47, through a common bipartite binding mechanism. The Journal of biological chemistry 279, 49609-49616.

Colanzi, A., Deerinck, T.J., Ellisman, M.H., and Malhotra, V. (2000). A specific activation of the mitogen-activated protein kinase kinase 1 (MEK1) is required for Golgi fragmentation during mitosis. The Journal of cell biology 149, 331-339.

Colanzi, A., Hidalgo Carcedo, C., Persico, A., Cericola, C., Turacchio, G., Bonazzi, M., Luini, A., and Corda, D. (2007). The Golgi mitotic checkpoint is controlled by BARSdependent fission of the Golgi ribbon into separate stacks in G2. The EMBO journal 26, 2465-2476.

Colanzi, A., Suetterlin, C., and Malhotra, V. (2003a). Cell-cycle-specific Golgi fragmentation: how and why? Current opinion in cell biology 15, 462-467.

Colanzi, A., Sutterlin, C., and Malhotra, V. (2003b). RAF1-activated MEK1 is found on the Golgi apparatus in late prophase and is required for Golgi complex fragmentation in mitosis. The Journal of cell biology $161,27-32$.

Conn, C.W., Hennigan, R.F., Dai, W., Sanchez, Y., and Stambrook, P.J. (2000). Incomplete cytokinesis and induction of apoptosis by overexpression of the mammalian polo-like kinase, Plk3. Cancer research 60, 6826-6831. 
Corda, D., Colanzi, A., and Luini, A. (2006). The multiple activities of CtBP/BARS proteins: the Golgi view. Trends in cell biology 16, 167-173.

Cullen, C.F., Brittle, A.L., Ito, T., and Ohkura, H. (2005). The conserved kinase NHK-1 is essential for mitotic progression and unifying acentrosomal meiotic spindles in Drosophila melanogaster. The Journal of cell biology 171, 593-602.

Chang, L., and Karin, M. (2001). Mammalian MAP kinase signalling cascades. Nature $410,37-40$.

Chase, D., Feng, Y., Hanshew, B., Winkles, J.A., Longo, D.L., and Ferris, D.K. (1998). Expression and phosphorylation of fibroblast-growth-factor-inducible kinase (Fnk) during cell-cycle progression. The Biochemical journal 333 ( Pt 3), 655-660.

Chiu, V.K., Bivona, T., Hach, A., Sajous, J.B., Silletti, J., Wiener, H., Johnson, R.L., 2nd, Cox, A.D., and Philips, M.R. (2002). Ras signalling on the endoplasmic reticulum and the Golgi. Nature cell biology 4, 343-350.

Dai, R.M., Chen, E., Longo, D.L., Gorbea, C.M., and Li, C.C. (1998). Involvement of valosin-containing protein, an ATPase Co-purified with IkappaBalpha and $26 \mathrm{~S}$ proteasome, in ubiquitin-proteasome-mediated degradation of IkappaBalpha. The Journal of biological chemistry $273,3562-3573$.

Dai, R.M., and Li, C.C. (2001). Valosin-containing protein is a multi-ubiquitin chaintargeting factor required in ubiquitin-proteasome degradation. Nature cell biology 3 , 740-744.

Dai, W., Li, Y., Ouyang, B., Pan, H., Reissmann, P., Li, J., Wiest, J., Stambrook, P., Gluckman, J.L., Noffsinger, A., and Bejarano, P. (2000). PRK, a cell cycle gene localized to $8 \mathrm{p} 21$, is downregulated in head and neck cancer. Genes, chromosomes \& cancer 27, 332-336.

Dai, W., Liu, T., Wang, Q., Rao, C.V., and Reddy, B.S. (2002a). Down-regulation of PLK3 gene expression by types and amount of dietary fat in rat colon tumors. International journal of oncology 20, 121-126.

Dai, W., Wang, Q., and Traganos, F. (2002b). Polo-like kinases and centrosome regulation. Oncogene 21, 6195-6200.

Dinter, A., and Berger, E.G. (1998). Golgi-disturbing agents. Histochemistry and cell biology 109, 571-590.

Dirac-Svejstrup, A.B., Shorter, J., Waters, M.G., and Warren, G. (2000). Phosphorylation of the vesicle-tethering protein p115 by a casein kinase II-like enzyme is required for Golgi reassembly from isolated mitotic fragments. The Journal of cell biology $150,475-488$.

Donaldson, J.G., and Lippincott-Schwartz, J. (2000). Sorting and signaling at the Golgi complex. Cell 101, 693-696.

Donohue, P.J., Alberts, G.F., Guo, Y., and Winkles, J.A. (1995). Identification by targeted differential display of an immediate early gene encoding a putative serine/threonine kinase. In: The Journal of biological chemistry, vol. 270, 10351-10357. 
Dreveny, I., Kondo, H., Uchiyama, K., Shaw, A., Zhang, X., and Freemont, P.S. (2004). Structural basis of the interaction between the AAA ATPase p97/VCP and its adaptor protein p47. The EMBO journal 23, 1030-1039.

Dudley, D.T., Pang, L., Decker, S.J., Bridges, A.J., and Saltiel, A.R. (1995). A synthetic inhibitor of the mitogen-activated protein kinase cascade. Proceedings of the National Academy of Sciences of the United States of America 92, 7686-7689.

Duran, J.M., Kinseth, M., Bossard, C., Rose, D.W., Polishchuk, R., Wu, C.C., Yates, J., Zimmerman, T., and Malhotra, V. (2008). The role of GRASP55 in Golgi fragmentation and entry of cells into mitosis. Molecular biology of the cell 19, 2579-2587.

Elia, A.E., Cantley, L.C., and Yaffe, M.B. (2003a). Proteomic screen finds pSer/pThrbinding domain localizing Plk1 to mitotic substrates. Science (New York, N.Y 299, 1228-1231.

Elia, A.E., Rellos, P., Haire, L.F., Chao, J.W., Ivins, F.J., Hoepker, K., Mohammad, D., Cantley, L.C., Smerdon, S.J., and Yaffe, M.B. (2003b). The molecular basis for phosphodependent substrate targeting and regulation of Plks by the Polo-box domain. Cell 115, 83-95.

Farquhar, M.G., and Palade, G.E. (1998). The Golgi apparatus: 100 years of progress and controversy. Trends in cell biology $8,2-10$.

Feinstein, T.N., and Linstedt, A.D. (2007). Mitogen-activated protein kinase kinase 1dependent Golgi unlinking occurs in $\mathrm{G} 2$ phase and promotes the G2/M cell cycle transition. Molecular biology of the cell 18, 594-604.

Feinstein, T.N., and Linstedt, A.D. (2008). GRASP55 regulates Golgi ribbon formation. Molecular biology of the cell 19, 2696-2707.

Feng, L., Xie, X., Ding, Q., Luo, X., He, J., Fan, F., Liu, W., Wang, Z., and Chen, Y. (2007). Spatial regulation of Raf kinase signaling by RKTG. Proceedings of the National Academy of Sciences of the United States of America 104, 14348-14353.

Fode, C., Motro, B., Yousefi, S., Heffernan, M., and Dennis, J.W. (1994). Sak, a murine protein-serine/threonine kinase that is related to the Drosophila polo kinase and involved in cell proliferation. Proceedings of the National Academy of Sciences of the United States of America 91, 6388-6392.

Fournier, M.V., Martin, K.J., Kenny, P.A., Xhaja, K., Bosch, I., Yaswen, P., and Bissell, M.J. (2006). Gene expression signature in organized and growth-arrested mammary acini predicts good outcome in breast cancer. Cancer research 66, 7095-7102.

Godinho, S., and Tavares, A.A. (2008). A role for Drosophila Polo protein in chromosome resolution and segregation during mitosis. Cell cycle (Georgetown, Tex 7, 2529-2534.

Gorjanacz, M., Klerkx, E.P., Galy, V., Santarella, R., Lopez-Iglesias, C., Askjaer, P., and Mattaj, I.W. (2007). Caenorhabditis elegans BAF-1 and its kinase VRK-1 participate directly in post-mitotic nuclear envelope assembly. The EMBO journal 26, 132-143. 
Graves, P.R., and Roach, P.J. (1995). Role of $\mathrm{COOH}$-terminal phosphorylation in the regulation of casein kinase I delta. The Journal of biological chemistry 270, 2168921694.

Guermah, M., Palhan, V.B., Tackett, A.J., Chait, B.T., and Roeder, R.G. (2006). Synergistic functions of SII and p300 in productive activator-dependent transcription of chromatin templates. Cell 125, 275-286.

Guo, B., Yang, S.H., Witty, J., and Sharrocks, A.D. (2007). Signalling pathways and the regulation of SUMO modification. Biochemical Society transactions 35, 1414-1418.

Hanks, S.K., and Hunter, T. (1995). Protein kinases 6. The eukaryotic protein kinase superfamily: kinase (catalytic) domain structure and classification. Faseb J 9, 576-596.

Hanks, S.K., Quinn, A.M., and Hunter, T. (1988). The protein kinase family: conserved features and deduced phylogeny of the catalytic domains. Science (New York, N.Y $241,42-52$.

Haraguchi, T., Koujin, T., Segura-Totten, M., Lee, K.K., Matsuoka, Y., Yoneda, Y., Wilson, K.L., and Hiraoka, Y. (2001). BAF is required for emerin assembly into the reforming nuclear envelope. J Cell Sci 114, 4575-4585.

Harding, A., Tian, T., Westbury, E., Frische, E., and Hancock, J.F. (2005). Subcellular localization determines MAP kinase signal output. Curr Biol 15, 869-873.

Hausser, A., Storz, P., Martens, S., Link, G., Toker, A., and Pfizenmaier, K. (2005). Protein kinase $D$ regulates vesicular transport by phosphorylating and activating phosphatidylinositol-4 kinase IIlbeta at the Golgi complex. Nature cell biology 7, 880886.

Hetzer, M., Meyer, H.H., Walther, T.C., Bilbao-Cortes, D., Warren, G., and Mattaj, I.W. (2001). Distinct AAA-ATPase p97 complexes function in discrete steps of nuclear assembly. Nature cell biology 3, 1086-1091.

Hidalgo Carcedo, C., Bonazzi, M., Spano, S., Turacchio, G., Colanzi, A., Luini, A., and Corda, D. (2004). Mitotic Golgi partitioning is driven by the membrane-fissioning protein CtBP3/BARS. Science (New York, N.Y 305, 93-96.

Ho, Y., Mason, S., Kobayashi, R., Hoekstra, M., and Andrews, B. (1997). Role of the casein kinase I isoform, Hrr25, and the cell cycle-regulatory transcription factor, SBF, in the transcriptional response to DNA damage in Saccharomyces cerevisiae. Proceedings of the National Academy of Sciences of the United States of America 94, 581-586.

Hoekstra, M.F., Liskay, R.M., Ou, A.C., DeMaggio, A.J., Burbee, D.G., and Heffron, F. (1991). HRR25, a putative protein kinase from budding yeast: association with repair of damaged DNA. Science (New York, N.Y 253, 1031-1034.

Hofmann, K. (2009). Ubiquitin-binding domains and their role in the DNA damage response. DNA repair $8,544-556$. 
lida, M., Matsuda, M., and Komatani, H. (2008). Plk3 phosphorylates topoisomerase Ilalpha at $\operatorname{Thr}(1342)$, a site that is not recognized by Plk1. The Biochemical journal 411, 27-32.

Ikeda, F., and Dikic, I. (2008). Atypical ubiquitin chains: new molecular signals. 'Protein Modifications: Beyond the Usual Suspects' review series. EMBO reports 9, 536-542.

Ivanovska, I., Khandan, T., Ito, T., and Orr-Weaver, T.L. (2005). A histone code in meiosis: the histone kinase, $\mathrm{NHK}-1$, is required for proper chromosomal architecture in Drosophila oocytes. Genes \& development 19, 2571-2582.

Jang, Y.J., Lin, C.Y., Ma, S., and Erikson, R.L. (2002a). Functional studies on the role of the C-terminal domain of mammalian polo-like kinase. Proceedings of the National Academy of Sciences of the United States of America 99, 1984-1989.

Jang, Y.J., Ma, S., Terada, Y., and Erikson, R.L. (2002b). Phosphorylation of threonine 210 and the role of serine 137 in the regulation of mammalian polo-like kinase. The Journal of biological chemistry $277,44115-44120$.

Jesch, S.A., Lewis, T.S., Ahn, N.G., and Linstedt, A.D. (2001a). Mitotic phosphorylation of Golgi reassembly stacking protein 55 by mitogen-activated protein kinase ERK2. Molecular biology of the cell 12, 1811-1817.

Jesch, S.A., Mehta, A.J., Velliste, M., Murphy, R.F., and Linstedt, A.D. (2001b). Mitotic Golgi is in a dynamic equilibrium between clustered and free vesicles independent of the ER. Traffic (Copenhagen, Denmark) 2, 873-884.

Jiang, N., Wang, X., Jhanwar-Uniyal, M., Darzynkiewicz, Z., and Dai, W. (2006). Polo box domain of Plk3 functions as a centrosome localization signal, overexpression of which causes mitotic arrest, cytokinesis defects, and apoptosis. The Journal of biological chemistry 281, 10577-10582.

Johannessen, M., Delghandi, M.P., and Moens, U. (2004). What turns CREB on? Cellular signalling 16, 1211-1227.

Johansen, K.M., and Johansen, J. (2006). Regulation of chromatin structure by histone H3S10 phosphorylation. Chromosome Res 14, 393-404.

Johnson, G.L., and Lapadat, R. (2002). Mitogen-activated protein kinase pathways mediated by ERK, JNK, and p38 protein kinases. Science (New York, N.Y 298, 19111912.

Jokitalo, E., Cabrera-Poch, N., Warren, G., and Shima, D.T. (2001). Golgi clusters and vesicles mediate mitotic inheritance independently of the endoplasmic reticulum. The Journal of cell biology 154, 317-330.

Jordan, J.D., Landau, E.M., and lyengar, R. (2000). Signaling networks: the origins of cellular multitasking. Cell 103, 193-200.

Kamath, R.S., Fraser, A.G., Dong, Y., Poulin, G., Durbin, R., Gotta, M., Kanapin, A., Le Bot, N., Moreno, S., Sohrmann, M., Welchman, D.P., Zipperlen, P., and Ahringer, J. (2003). Systematic functional analysis of the Caenorhabditis elegans genome using RNAi. Nature 421, 231-237. 
Kang, T.H., and Kim, K.T. (2006). Negative regulation of ERK activity by VRK3mediated activation of VHR phosphatase. Nature cell biology 8, 863-869.

Kang, T.H., and Kim, K.T. (2008). VRK3-mediated inactivation of ERK signaling in adult and embryonic rodent tissues. Biochimica et biophysica acta 1783, 49-58.

Kang, T.H., Park, D.Y., Choi, Y.H., Kim, K.J., Yoon, H.S., and Kim, K.T. (2007). Mitotic histone $\mathrm{H} 3$ phosphorylation by vaccinia-related kinase 1 in mammalian cells. Molecular and cellular biology $27,8533-8546$.

Kang, T.H., Park, D.Y., Kim, W., and Kim, K.T. (2008). VRK1 phosphorylates CREB and mediates CCND1 expression. J Cell Sci 121, 3035-3041.

Kang, Y.H., Park, J.E., Yu, L.R., Soung, N.K., Yun, S.M., Bang, J.K., Seong, Y.S., Yu, H., Garfield, S., Veenstra, T.D., and Lee, K.S. (2006). Self-regulated Plk1 recruitment to kinetochores by the Plk1-PBIP1 interaction is critical for proper chromosome segregation. Molecular cell 24, 409-422.

Kano, F., Kondo, H., Yamamoto, A., Kaneko, Y., Uchiyama, K., Hosokawa, N., Nagata, K., and Murata, M. (2005). NSF/SNAPs and p97/p47/VCIP135 are sequentially required for cell cycle-dependent reformation of the ER network. Genes Cells 10, 989999.

Kano, F., Takenaka, K., Yamamoto, A., Nagayama, K., Nishida, E., and Murata, M. (2000). MEK and Cdc2 kinase are sequentially required for Golgi disassembly in MDCK cells by the mitotic Xenopus extracts. The Journal of cell biology 149, 357-368.

Kauselmann, G., Weiler, M., Wulff, P., Jessberger, S., Konietzko, U., Scafidi, J., Staubli, U., Bereiter-Hahn, J., Strebhardt, K., and Kuhl, D. (1999). The polo-like protein kinases Fnk and Snk associate with a $\mathrm{Ca}(2+)$ - and integrin-binding protein and are regulated dynamically with synaptic plasticity. The EMBO journal 18, 5528-5539.

Kitada, K., Johnson, A.L., Johnston, L.H., and Sugino, A. (1993). A multicopy suppressor gene of the Saccharomyces cerevisiae G1 cell cycle mutant gene dbf4 encodes a protein kinase and is identified as CDC5. Molecular and cellular biology 13, $4445-4457$.

Klein, J.B., Barati, M.T., Wu, R., Gozal, D., Sachleben, L.R., Jr., Kausar, H., Trent, J.O., Gozal, E., and Rane, M.J. (2005). Akt-mediated valosin-containing protein 97 phosphorylation regulates its association with ubiquitinated proteins. The Journal of biological chemistry 280, 31870-31881.

Klerkx, E.P., Alarcon, P., Waters, K., Reinke, V., Sternberg, P.W., and Askjaer, P. (2009a). Protein kinase VRK-1 regulates cell invasion and EGL-17/FGF signaling in Caenorhabditis elegans. Developmental biology 335, 12-21.

Klerkx, E.P., Lazo, P.A., and Askjaer, P. (2009b). Emerging biological functions of the vaccinia-related kinase (VRK) family. Histology and histopathology 24, 749-759.

Kondo, H., Rabouille, C., Newman, R., Levine, T.P., Pappin, D., Freemont, P., and Warren, G. (1997). p47 is a cofactor for p97-mediated membrane fusion. Nature 388, 75-78. 
Kussie, P.H., Gorina, S., Marechal, V., Elenbaas, B., Moreau, J., Levine, A.J., and Pavletich, N.P. (1996). Structure of the MDM2 oncoprotein bound to the p53 tumor suppressor transactivation domain. Science (New York, N.Y 274, 948-953.

Ladinsky, M.S., Mastronarde, D.N., Mclntosh, J.R., Howell, K.E., and Staehelin, L.A. (1999). Golgi structure in three dimensions: functional insights from the normal rat kidney cell. The Journal of cell biology 144, 1135-1149.

Laemmli, U.K. (1970). Cleavage of structural proteins during the assembly of the head of bacteriophage T4. Nature 227, 680-685.

Laird, A.D., Morrison, D.K., and Shalloway, D. (1999). Characterization of Raf-1 activation in mitosis. The Journal of biological chemistry $274,4430-4439$.

Lancaster, O.M., Cullen, C.F., and Ohkura, H. (2007). NHK-1 phosphorylates BAF to allow karyosome formation in the Drosophila oocyte nucleus. The Journal of cell biology $179,817-824$.

Latterich, M., Frohlich, K.U., and Schekman, R. (1995). Membrane fusion and the cell cycle: Cdc48p participates in the fusion of ER membranes. Cell 82, 885-893.

Laude, A.J., and Prior, I.A. (2004). Plasma membrane microdomains: organization, function and trafficking. Molecular membrane biology 21, 193-205.

Lee, K.S., and Erikson, R.L. (1997). PIk is a functional homolog of Saccharomyces cerevisiae Cdc5, and elevated Plk activity induces multiple septation structures. Molecular and cellular biology 17, 3408-3417.

Lee, K.S., Grenfell, T.Z., Yarm, F.R., and Erikson, R.L. (1998). Mutation of the polo-box disrupts localization and mitotic functions of the mammalian polo kinase Plk. Proceedings of the National Academy of Sciences of the United States of America 95, 9301-9306.

Letunic, I., Goodstadt, L., Dickens, N.J., Doerks, T., Schultz, J., Mott, R., Ciccarelli, F., Copley, R.R., Ponting, C.P., and Bork, P. (2002). Recent improvements to the SMART domain-based sequence annotation resource. Nucleic acids research 30, 242-244.

Leung, G.C., Hudson, J.W., Kozarova, A., Davidson, A., Dennis, J.W., and Sicheri, F. (2002). The Sak polo-box comprises a structural domain sufficient for mitotic subcellular localization. Nature structural biology 9, 719-724.

Levine, A.J. (1997). p53, the cellular gatekeeper for growth and division. Cell 88, 323331.

Li, B., Ouyang, B., Pan, H., Reissmann, P.T., Slamon, D.J., Arceci, R., Lu, L., and Dai, W. (1996). Prk, a cytokine-inducible human protein serine/threonine kinase whose expression appears to be down-regulated in lung carcinomas. The Journal of biological chemistry $271,19402-19408$.

Li, Q., Lau, A., Morris, T.J., Guo, L., Fordyce, C.B., and Stanley, E.F. (2004). A syntaxin 1, Galpha(o), and N-type calcium channel complex at a presynaptic nerve terminal: analysis by quantitative immunocolocalization. J Neurosci $24,4070-4081$. 
Li, Z., Niu, J., Uwagawa, T., Peng, B., and Chiao, P.J. (2005). Function of polo-like kinase 3 in NF-kappaB-mediated proapoptotic response. The Journal of biological chemistry $280,16843-16850$.

Liljedahl, M., Maeda, Y., Colanzi, A., Ayala, I., Van Lint, J., and Malhotra, V. (2001). Protein kinase $D$ regulates the fission of cell surface destined transport carriers from the trans-Golgi network. Cell 104, 409-420.

Lin, C.Y., Madsen, M.L., Yarm, F.R., Jang, Y.J., Liu, X., and Erikson, R.L. (2000). Peripheral Golgi protein GRASP65 is a target of mitotic polo-like kinase (Plk) and Cdc2. Proceedings of the National Academy of Sciences of the United States of America 97, 12589-12594.

Lin, S., Chen, W., and Broyles, S.S. (1992). The vaccinia virus B1R gene product is a serine/threonine protein kinase. Journal of virology $66,2717-2723$.

Linstedt, A.D., Foguet, M., Renz, M., Seelig, H.P., Glick, B.S., and Hauri, H.P. (1995). A C-terminally-anchored Golgi protein is inserted into the endoplasmic reticulum and then transported to the Golgi apparatus. Proceedings of the National Academy of Sciences of the United States of America 92, 5102-5105.

Linstedt, A.D., and Hauri, H.P. (1993). Giantin, a novel conserved Golgi membrane protein containing a cytoplasmic domain of at least $350 \mathrm{kDa}$. Molecular biology of the cell 4, 679-693.

Lippincott-Schwartz, J., Yuan, L.C., Bonifacino, J.S., and Klausner, R.D. (1989). Rapid redistribution of Golgi proteins into the ER in cells treated with brefeldin A: evidence for membrane cycling from Golgi to ER. Cell 56, 801-813.

Liu, Y., Jiang, N., Wu, J., Dai, W., and Rosenblum, J.S. (2007). Polo-like kinases inhibited by wortmannin. Labeling site and downstream effects. The Journal of biological chemistry 282, 2505-2511.

Livingstone, M., Ruan, H., Weiner, J., Clauser, K.R., Strack, P., Jin, S., Williams, A., Greulich, H., Gardner, J., Venere, M., Mochan, T.A., DiTullio, R.A., Jr., Moravcevic, K., Gorgoulis, V.G., Burkhardt, A., and Halazonetis, T.D. (2005). Valosin-containing protein phosphorylation at Ser784 in response to DNA damage. Cancer research $65,7533-$ 7540 .

Lopez-Borges, S., and Lazo, P.A. (2000). The human vaccinia-related kinase 1 (VRK1) phosphorylates threonine-18 within the mdm-2 binding site of the p53 tumour suppressor protein. Oncogene 19, 3656-3664.

Lopez-Sanchez, I., Sanz-Garcia, M., and Lazo, P.A. (2009). Plk3 interacts with and specifically phosphorylates VRK1 in Ser342, a downstream target in a pathway that induces Golgi fragmentation. Molecular and cellular biology 29, 1189-1201.

Lowe, M., Gonatas, N.K., and Warren, G. (2000). The mitotic phosphorylation cycle of the cis-Golgi matrix protein GM130. The Journal of cell biology 149, 341-356.

Lowe, M., Rabouille, C., Nakamura, N., Watson, R., Jackman, M., Jamsa, E., Rahman, D., Pappin, D.J., and Warren, G. (1998). Cdc2 kinase directly phosphorylates the cis- 
Golgi matrix protein GM130 and is required for Golgi fragmentation in mitosis. Cell 94, 783-793.

Lu, B., and Bishop, C.E. (2003). Late onset of spermatogenesis and gain of fertility in POG-deficient mice indicate that POG is not necessary for the proliferation of spermatogonia. Biology of reproduction $69,161-168$.

Lucocq, J., Berger, E., and Hug, C. (1995). The pathway of Golgi cluster formation in okadaic acid-treated cells. Journal of structural biology 115, 318-330.

Luttrell, L.M., Roudabush, F.L., Choy, E.W., Miller, W.E., Field, M.E., Pierce, K.L., and Lefkowitz, R.J. (2001). Activation and targeting of extracellular signal-regulated kinases by beta-arrestin scaffolds. Proceedings of the National Academy of Sciences of the United States of America 98, 2449-2454.

Llamazares, S., Moreira, A., Tavares, A., Girdham, C., Spruce, B.A., Gonzalez, C., Karess, R.E., Glover, D.M., and Sunkel, C.E. (1991). polo encodes a protein kinase homolog required for mitosis in Drosophila. Genes \& development 5, 2153-2165.

Manders, E. (1993). Measurement of colocalization of objects in dual-color confocal images. Journal of Microscopy 169, 375-382.

Manders, E., Stap,J.,Brakenhoff,G.,van Driel, R., and Aten,J. (1992). Dynamics of three-dimensional replication patterns during the S-phase, analysed by double labelling of DNA and confocal microscopy. J Cell Sci 103, 857-862.

Manning, G., Whyte, D.B., Martinez, R., Hunter, T., and Sudarsanam, S. (2002). The protein kinase complement of the human genome. Science (New York, N.Y 298, 19121934.

Martin, K.J., Patrick, D.R., Bissell, M.J., and Fournier, M.V. (2008). Prognostic breast cancer signature identified from 3D culture model accurately predicts clinical outcome across independent datasets. Plos one 3, e2994.

Mehlgarten, C., and Schaffrath, R. (2003). Mutant casein kinase I (Hrr25p/Kti14p) abrogates the $\mathrm{G} 1$ cell cycle arrest induced by Kluyveromyces lactiszymocin in budding yeast. Mol Genet Genomics 269, 188-196.

Meyer, H.H., Shorter, J.G., Seemann, J., Pappin, D., and Warren, G. (2000). A complex of mammalian ufd1 and npl4 links the AAA-ATPase, p97, to ubiquitin and nuclear transport pathways. The EMBO journal 19, 2181-2192.

Meyer, H.H., Wang, Y., and Warren, G. (2002). Direct binding of ubiquitin conjugates by the mammalian p97 adaptor complexes, p47 and Ufd1-Npl4. The EMBO journal 21, 5645-5652.

Michalak, M., Milner, R.E., Burns, K., and Opas, M. (1992). Calreticulin. The Biochemical journal 285 ( Pt 3), 681-692.

Misteli, T., and Warren, G. (1994). COP-coated vesicles are involved in the mitotic fragmentation of Golgi stacks in a cell-free system. The Journal of cell biology 125 , 269-282. 
Monti, M., Orru, S., Pagnozzi, D., and Pucci, P. (2005). Interaction proteomics. Bioscience reports 25, 45-56.

Mor, A., and Philips, M.R. (2006). Compartmentalized Ras/MAPK signaling. Annual review of immunology $24,771-800$.

Mori-Konya, C., Kato, N., Maeda, R., Yasuda, K., Higashimae, N., Noguchi, M., Koike, M., Kimura, Y., Ohizumi, H., Hori, S., and Kakizuka, A. (2009). p97/valosin-containing protein (VCP) is highly modulated by phosphorylation and acetylation. Genes Cells 14, 483-497.

Morrison, D.K., Murakami, M.S., and Cleghon, V. (2000). Protein kinases and phosphatases in the Drosophila genome. The Journal of cell biology 150, F57-62.

Morton, S., Davis, R.J., and Cohen, P. (2004). Signalling pathways involved in multisite phosphorylation of the transcription factor ATF-2. FEBS letters 572, 177-183.

Mundt, K.E., Golsteyn, R.M., Lane, H.A., and Nigg, E.A. (1997). On the regulation and function of human polo-like kinase 1 (PLK1): effects of overexpression on cell cycle progression. Biochemical and biophysical research communications 239, 377-385.

Myer, D.L., Bahassi el, M., and Stambrook, P.J. (2005). The Plk3-Cdc25 circuit. Oncogene 24, 299-305.

Nakamura, N., Lowe, M., Levine, T.P., Rabouille, C., and Warren, G. (1997). The vesicle docking protein $\mathrm{p} 115$ binds GM130, a cis-Golgi matrix protein, in a mitotically regulated manner. Cell 89, 445-455.

Nakamura, N., Rabouille, C., Watson, R., Nilsson, T., Hui, N., Slusarewicz, P., Kreis, T.E., and Warren, G. (1995). Characterization of a cis-Golgi matrix protein, GM130. The Journal of cell biology 131, 1715-1726.

Nezu, J., Oku, A., Jones, M.H., and Shimane, M. (1997). Identification of two novel human putative serine/threonine kinases, VRK1 and VRK2, with structural similarity to vaccinia virus B1R kinase. Genomics 45, 327-331.

Nichols, R.J., and Traktman, P. (2004). Characterization of three paralogous members of the Mammalian vaccinia related kinase family. The Journal of biological chemistry 279, 7934-7946.

Nichols, R.J., Wiebe, M.S., and Traktman, P. (2006). The vaccinia-related kinases phosphorylate the $\mathrm{N}^{\prime}$ terminus of BAF, regulating its interaction with DNA and its retention in the nucleus. Molecular biology of the cell 17, 2451-2464.

Nigg, E.A. (1995). Cyclin-dependent protein kinases: key regulators of the eukaryotic cell cycle. Bioessays 17, 471-480.

Nigg, E.A. (1998). Polo-like kinases: positive regulators of cell division from start to finish. Current opinion in cell biology 10, 776-783.

Nolen, B., Taylor, S., and Ghosh, G. (2004). Regulation of protein kinases; controlling activity through activation segment conformation. Molecular cell 15, 661-675. 
Ohkura, H., Hagan, I.M., and Glover, D.M. (1995). The conserved Schizosaccharomyces pombe kinase plo1, required to form a bipolar spindle, the actin ring, and septum, can drive septum formation in $\mathrm{G} 1$ and $\mathrm{G} 2$ cells. Genes \& development 9, 1059-1073.

Olsen, J.V., Blagoev, B., Gnad, F., Macek, B., Kumar, C., Mortensen, P., and Mann, M. (2006). Global, in vivo, and site-specific phosphorylation dynamics in signaling networks. Cell 127, 635-648.

Ouyang, B., Li, W., Pan, H., Meadows, J., Hoffmann, I., and Dai, W. (1999). The physical association and phosphorylation of Cdc25C protein phosphatase by Prk. Oncogene 18, 6029-6036.

Ouyang, B., Pan, H., Lu, L., Li, J., Stambrook, P., Li, B., and Dai, W. (1997). Human Prk is a conserved protein serine/threonine kinase involved in regulating $M$ phase functions. The Journal of biological chemistry 272, 28646-28651.

Partridge, J.J., Lopreiato, J.O., Jr., Latterich, M., and Indig, F.E. (2003). DNA damage modulates nucleolar interaction of the Werner protein with the AAA ATPase p97/VCP. Molecular biology of the cell 14, 4221-4229.

Pawson, T., and Nash, P. (2003). Assembly of cell regulatory systems through protein interaction domains. Science (New York, N.Y 300, 445-452.

Pecot, M.Y., and Malhotra, V. (2004). Golgi membranes remain segregated from the endoplasmic reticulum during mitosis in mammalian cells. Cell 116, 99-107.

Pelletier, L., Jokitalo, E., and Warren, G. (2000). The effect of Golgi depletion on exocytic transport. Nature cell biology 2, 840-846.

Perkins, D.N., Pappin, D.J., Creasy, D.M., and Cottrell, J.S. (1999). Probability-based protein identification by searching sequence databases using mass spectrometry data. Electrophoresis 20, 3551-3567.

Persico, A., Cervigni, R.I., Barretta, M.L., and Colanzi, A. (2009). Mitotic inheritance of the Golgi complex. FEBS letters 583, 3857-3862.

Piano, F., Schetter, A.J., Mangone, M., Stein, L., and Kemphues, K.J. (2000). RNAi analysis of genes expressed in the ovary of Caenorhabditis elegans. Curr Biol 10, 1619-1622.

Praskova, M., Khoklatchev, A., Ortiz-Vega, S., and Avruch, J. (2004). Regulation of the MST1 kinase by autophosphorylation, by the growth inhibitory proteins, RASSF1 and NORE1, and by Ras. The Biochemical journal 381, 453-462.

Preisinger, C., Short, B., De Corte, V., Bruyneel, E., Haas, A., Kopajtich, R., Gettemans, J., and Barr, F.A. (2004). YSK1 is activated by the Golgi matrix protein GM130 and plays a role in cell migration through its substrate 14-3-3zeta. The Journal of cell biology $164,1009-1020$.

Puntervoll, P., Linding, R., Gemund, C., Chabanis-Davidson, S., Mattingsdal, M., Cameron, S., Martin, D.M., Ausiello, G., Brannetti, B., Costantini, A., Ferre, F., Maselli, V., Via, A., Cesareni, G., Diella, F., Superti-Furga, G., Wyrwicz, L., Ramu, C., 
McGuigan, C., Gudavalli, R., Letunic, I., Bork, P., Rychlewski, L., Kuster, B., HelmerCitterich, M., Hunter, W.N., Aasland, R., and Gibson, T.J. (2003). ELM server: A new resource for investigating short functional sites in modular eukaryotic proteins. Nucleic acids research $31,3625-3630$.

Puthenveedu, M.A., Bachert, C., Puri, S., Lanni, F., and Linstedt, A.D. (2006). GM130 and GRASP65-dependent lateral cisternal fusion allows uniform Golgi-enzyme distribution. Nature cell biology 8, 238-248.

Rabouille, C., Kondo, H., Newman, R., Hui, N., Freemont, P., and Warren, G. (1998). Syntaxin 5 is a common component of the NSF- and p97-mediated reassembly pathways of Golgi cisternae from mitotic Golgi fragments in vitro. Cell 92, 603-610.

Rabouille, C., Levine, T.P., Peters, J.M., and Warren, G. (1995). An NSF-like ATPase, p97, and NSF mediate cisternal regrowth from mitotic Golgi fragments. Cell 82, 905914.

Ramirez, I.B., and Lowe, M. (2009). Golgins and GRASPs: holding the Golgi together. Seminars in cell \& developmental biology $20,770-779$.

Renbaum, P., Kellerman, E., Jaron, R., Geiger, D., Segel, R., Lee, M., King, M.C., and Levy-Lahad, E. (2009). Spinal muscular atrophy with pontocerebellar hypoplasia is caused by a mutation in the VRK1 gene. American journal of human genetics 85,281 289.

Roberts, E.C., Shapiro, P.S., Nahreini, T.S., Pages, G., Pouyssegur, J., and Ahn, N.G. (2002). Distinct cell cycle timing requirements for extracellular signal-regulated kinase and phosphoinositide 3-kinase signaling pathways in somatic cell mitosis. Molecular and cellular biology 22, 7226-7241.

Rogalski, A.A., and Singer, S.J. (1984). Associations of elements of the Golgi apparatus with microtubules. The Journal of cell biology 99, 1092-1100.

Rothman, J.E. (1994). Mechanisms of intracellular protein transport. Nature 372, 55-63.

Rothman, J.E., and Warren, G. (1994). Implications of the SNARE hypothesis for intracellular membrane topology and dynamics. Curr Biol 4, 220-233.

Ruan, Q., Wang, Q., Xie, S., Fang, Y., Darzynkiewicz, Z., Guan, K., Jhanwar-Uniyal, M., and Dai, W. (2004). Polo-like kinase 3 is Golgi localized and involved in regulating Golgi fragmentation during the cell cycle. Experimental cell research 294, 51-59.

Sambrook, J.a.D.W.R. (2001). Molecular Cloning. A laboratory manual: New York.

Sancar, A., Lindsey-Boltz, L.A., Unsal-Kacmaz, K., and Linn, S. (2004). Molecular mechanisms of mammalian DNA repair and the DNA damage checkpoints. Annual review of biochemistry $73,39-85$.

Sang, M., Ando, K., Okoshi, R., Koida, N., Li, Y., Zhu, Y., Shimozato, O., Geng, C., Shan, B., Nakagawara, A., and Ozaki, T. (2009). Plk3 inhibits pro-apoptotic activity of p73 through physical interaction and phosphorylation. Genes Cells 14, 775-788.

Santos, C.R., Rodriguez-Pinilla, M., Vega, F.M., Rodriguez-Peralto, J.L., Blanco, S., Sevilla, A., Valbuena, A., Hernandez, T., van Wijnen, A.J., Li, F., de Alava, E., 
Sanchez-Cespedes, M., and Lazo, P.A. (2006). VRK1 signaling pathway in the context of the proliferation phenotype in head and neck squamous cell carcinoma. Mol Cancer Res 4, 177-185.

Sanz-Garcia, M., Lopez-Sanchez, I., and Lazo, P.A. (2008). Proteomics identification of nuclear Ran GTPase as an inhibitor of human VRK1 and VRK2 (vaccinia-related kinase) activities. Mol Cell Proteomics 7, 2199-2214.

Scheeff, E.D., Eswaran, J., Bunkoczi, G., Knapp, S., and Manning, G. (2009). Structure of the pseudokinase VRK3 reveals a degraded catalytic site, a highly conserved kinase fold, and a putative regulatory binding site. Structure 17, 128-138.

Schnell, J.D., and Hicke, L. (2003). Non-traditional functions of ubiquitin and ubiquitinbinding proteins. The Journal of biological chemistry $278,35857-35860$.

Schon, O., Friedler, A., Bycroft, M., Freund, S.M., and Fersht, A.R. (2002). Molecular mechanism of the interaction between MDM2 and p53. Journal of molecular biology $323,491-501$.

Seeburg, D.P., Pak, D., and Sheng, M. (2005). Polo-like kinases in the nervous system. Oncogene 24, 292-298.

Seemann, J., Jokitalo, E., Pypaert, M., and Warren, G. (2000a). Matrix proteins can generate the higher order architecture of the Golgi apparatus. Nature 407, 1022-1026.

Seemann, J., Jokitalo, E.J., and Warren, G. (2000b). The role of the tethering proteins p115 and GM130 in transport through the Golgi apparatus in vivo. Molecular biology of the cell $11,635-645$.

Seemann, J., Pypaert, M., Taguchi, T., Malsam, J., and Warren, G. (2002). Partitioning of the matrix fraction of the Golgi apparatus during mitosis in animal cells. Science (New York, N.Y 295, 848-851.

Semizarov, D., Kroeger, P., and Fesik, S. (2004). siRNA-mediated gene silencing: a global genome view. Nucleic acids research 32, 3836-3845.

Seong, Y.S., Kamijo, K., Lee, J.S., Fernandez, E., Kuriyama, R., Miki, T., and Lee, K.S. (2002). A spindle checkpoint arrest and a cytokinesis failure by the dominant-negative polo-box domain of Plk1 in U-2 OS cells. The Journal of biological chemistry 277, 32282-32293.

Sevilla, A., Santos, C.R., Barcia, R., Vega, F.M., and Lazo, P.A. (2004a). C-Jun phosphorylation by the human vaccinia-related kinase 1 (VRK1) and its cooperation with the N-terminal kinase of c-Jun (JNK). Oncogene 23, 8950-8958.

Sevilla, A., Santos, C.R., Vega, F.M., and Lazo, P.A. (2004b). Human vaccinia-related kinase 1 (VRK1) activates the ATF2 transcriptional activity by novel phosphorylation on Thr-73 and Ser-62 and cooperates with JNK. The Journal of biological chemistry 279, 27458-27465.

Shapiro, P.S., Vaisberg, E., Hunt, A.J., Tolwinski, N.S., Whalen, A.M., McIntosh, J.R., and Ahn, N.G. (1998). Activation of the MKK/ERK pathway during somatic cell mitosis: 
direct interactions of active ERK with kinetochores and regulation of the mitotic $3 \mathrm{~F} 3 / 2$ phosphoantigen. The Journal of cell biology 142, 1533-1545.

Shaul, Y.D., Gibor, G., Plotnikov, A., and Seger, R. (2009). Specific phosphorylation and activation of ERK1c by MEK1b: a unique route in the ERK cascade. Genes \& development 23, 1779-1790.

Shaul, Y.D., and Seger, R. (2006). ERK1c regulates Golgi fragmentation during mitosis. The Journal of cell biology 172, 885-897.

Sherr, C.J. (1994). G1 phase progression: cycling on cue. Cell 79, 551-555.

Shiio, Y., Eisenman, R.N., Yi, E.C., Donohoe, S., Goodlett, D.R., and Aebersold, R. (2003). Quantitative proteomic analysis of chromatin-associated factors. Journal of the American Society for Mass Spectrometry 14, 696-703.

Shima, D.T., Cabrera-Poch, N., Pepperkok, R., and Warren, G. (1998). An ordered inheritance strategy for the Golgi apparatus: visualization of mitotic disassembly reveals a role for the mitotic spindle. The Journal of cell biology 141, 955-966.

Shima, D.T., Haldar, K., Pepperkok, R., Watson, R., and Warren, G. (1997). Partitioning of the Golgi apparatus during mitosis in living HeLa cells. The Journal of cell biology 137, 1211-1228.

Shiozawa, K., Goda, N., Shimizu, T., Mizuguchi, K., Kondo, N., Shimozawa, N., Shirakawa, M., and Hiroaki, H. (2006). The common phospholipid-binding activity of the N-terminal domains of PEX1 and VCP/p97. The FEBS journal 273, 4959-4971.

Shorter, J., and Warren, G. (1999). A role for the vesicle tethering protein, p115, in the post-mitotic stacking of reassembling Golgi cisternae in a cell-free system. The Journal of cell biology 146, 57-70.

Shorter, J., and Warren, G. (2002). Golgi architecture and inheritance. Annual review of cell and developmental biology 18, 379-420.

Shorter, J., Watson, R., Giannakou, M.E., Clarke, M., Warren, G., and Barr, F.A. (1999). GRASP55, a second mammalian GRASP protein involved in the stacking of Golgi cisternae in a cell-free system. The EMBO journal 18, 4949-4960.

Simmer, F., Moorman, C., van der Linden, A.M., Kuijk, E., van den Berghe, P.V., Kamath, R.S., Fraser, A.G., Ahringer, J., and Plasterk, R.H. (2003). Genome-wide RNAi of $C$. elegans using the hypersensitive rrf-3 strain reveals novel gene functions. PLoS biology 1, E12.

Sirri, V., Urcuqui-Inchima, S., Roussel, P., and Hernandez-Verdun, D. (2008). Nucleolus: the fascinating nuclear body. Histochemistry and cell biology 129, 13-31.

Sollner, T., Bennett, M.K., Whiteheart, S.W., Scheller, R.H., and Rothman, J.E. (1993). A protein assembly-disassembly pathway in vitro that may correspond to sequential steps of synaptic vesicle docking, activation, and fusion. Cell 75, 409-418.

Song, C., Wang, Q., and Li, C.C. (2003). ATPase activity of p97-valosin-containing protein (VCP). D2 mediates the major enzyme activity, and D1 contributes to the heatinduced activity. The Journal of biological chemistry 278, 3648-3655. 
Sonnichsen, B., Lowe, M., Levine, T., Jamsa, E., Dirac-Svejstrup, B., and Warren, G. (1998). A role for giantin in docking COPI vesicles to Golgi membranes. The Journal of cell biology 140, 1013-1021.

Stokes, M.P., Rush, J., Macneill, J., Ren, J.M., Sprott, K., Nardone, J., Yang, V., Beausoleil, S.A., Gygi, S.P., Livingstone, M., Zhang, H., Polakiewicz, R.D., and Comb, M.J. (2007). Profiling of UV-induced ATM/ATR signaling pathways. Proceedings of the National Academy of Sciences of the United States of America 104, 19855-19860.

Sunkel, C.E., and Glover, D.M. (1988). polo, a mitotic mutant of Drosophila displaying abnormal spindle poles. J Cell Sci 89 (Pt 1), 25-38.

Sutterlin, C., Hsu, P., Mallabiabarrena, A., and Malhotra, V. (2002). Fragmentation and dispersal of the pericentriolar Golgi complex is required for entry into mitosis in mammalian cells. Cell 109, 359-369.

Sutterlin, C., Lin, C.Y., Feng, Y., Ferris, D.K., Erikson, R.L., and Malhotra, V. (2001). Polo-like kinase is required for the fragmentation of pericentriolar Golgi stacks during mitosis. Proceedings of the National Academy of Sciences of the United States of America 98, 9128-9132.

Tang, D., Mar, K., Warren, G., and Wang, Y. (2008). Molecular mechanism of mitotic Golgi disassembly and reassembly revealed by a defined reconstitution assay. The Journal of biological chemistry 283, 6085-6094.

Tang, D., Yuan, H., and Wang, Y. (2010). The Role of GRASP65 in Golgi Cisternal Stacking and Cell Cycle Progression

Traffic (Copenhagen, Denmark).

Tategu, M., Nakagawa, H., Sasaki, K., Yamauchi, R., Sekimachi, S., Suita, Y., Watanabe, N., and Yoshid, K. (2008). Transcriptional regulation of human polo-like kinases and early mitotic inhibitor. J Genet Genomics 35, 215-224.

Thyberg, J., and Moskalewski, S. (1999). Role of microtubules in the organization of the Golgi complex. Experimental cell research 246, 263-279.

Torii, S., Kusakabe, M., Yamamoto, T., Maekawa, M., and Nishida, E. (2004). Sef is a spatial regulator for Ras/MAP kinase signaling. Developmental cell 7, 33-44.

Towbin, H., Staehelin, T., and Gordon, J. (1979). Electrophoretic transfer of proteins from polyacrylamide gels to nitrocellulose sheets: procedure and some applications. Proceedings of the National Academy of Sciences of the United States of America 76, $4350-4354$.

Uchiyama, K., Jokitalo, E., Kano, F., Murata, M., Zhang, X., Canas, B., Newman, R., Rabouille, C., Pappin, D., Freemont, P., and Kondo, H. (2002). VCIP135, a novel essential factor for p97/p47-mediated membrane fusion, is required for Golgi and ER assembly in vivo. The Journal of cell biology 159, 855-866.

Uchiyama, K., Jokitalo, E., Lindman, M., Jackman, M., Kano, F., Murata, M., Zhang, X., and Kondo, H. (2003). The localization and phosphorylation of p47 are important for Golgi disassembly-assembly during the cell cycle. The Journal of cell biology 161, 1067-1079. 
Uchiyama, K., Totsukawa, G., Puhka, M., Kaneko, Y., Jokitalo, E., Dreveny, I., Beuron, F., Zhang, X., Freemont, P., and Kondo, H. (2006). p37 is a p97 adaptor required for Golgi and ER biogenesis in interphase and at the end of mitosis. Developmental cell $11,803-816$.

Valbuena, A., Blanco, S., Vega, F.M., and Lazo, P.A. (2008a). The C/H3 domain of p300 is required to protect VRK1 and VRK2 from their downregulation induced by p53. Plos one 3, e2649.

Valbuena, A., Lopez-Sanchez, I., and Lazo, P.A. (2008b). Human VRK1 is an early response gene and its loss causes a block in cell cycle progression. Plos one 3, e1642.

Valbuena, A., Lopez-Sanchez, I., Vega, F.M., Sevilla, A., Sanz-Garcia, M., Blanco, S., and Lazo, P.A. (2007a). Identification of a dominant epitope in human vaccinia-related kinase 1 (VRK1) and detection of different intracellular subpopulations. Archives of biochemistry and biophysics 465, 219-226.

Valbuena, A., Suarez-Gauthier, A., Lopez-Rios, F., Lopez-Encuentra, A., Blanco, S., Fernandez, P.L., Sanchez-Cespedes, M., and Lazo, P.A. (2007b). Alteration of the VRK1-p53 autoregulatory loop in human lung carcinomas. Lung Cancer 58, 303-309.

Valbuena, A., Vega, F.M., Blanco, S., and Lazo, P.A. (2006). p53 downregulates its activating vaccinia-related kinase 1 , forming a new autoregulatory loop. Molecular and cellular biology $26,4782-4793$.

Valderrama, F., Babia, T., Ayala, I., Kok, J.W., Renau-Piqueras, J., and Egea, G. (1998). Actin microfilaments are essential for the cytological positioning and morphology of the Golgi complex. European journal of cell biology 76, 9-17.

van de Weerdt, B.C., Littler, D.R., Klompmaker, R., Huseinovic, A., Fish, A., Perrakis, A., and Medema, R.H. (2008). Polo-box domains confer target specificity to the Pololike kinase family. Biochimica et biophysica acta 1783, 1015-1022.

Vandermoere, F., El Yazidi-Belkoura, I., Slomianny, C., Demont, Y., Bidaux, G., Adriaenssens, E., Lemoine, J., and Hondermarck, H. (2006). The valosin-containing protein (VCP) is a target of Akt signaling required for cell survival. The Journal of biological chemistry $281,14307-14313$.

Vega, F.M., Gonzalo, P., Gaspar, M.L., and Lazo, P.A. (2003). Expression of the VRK (vaccinia-related kinase) gene family of p53 regulators in murine hematopoietic development. FEBS letters 544, 176-180.

Vega, F.M., Sevilla, A., and Lazo, P.A. (2004). p53 Stabilization and accumulation induced by human vaccinia-related kinase 1 . Molecular and cellular biology $24,10366-$ 10380.

Vernell, R., Helin, K., and Muller, H. (2003). Identification of target genes of the p16INK4A-pRB-E2F pathway. The Journal of biological chemistry 278, 46124-46137.

Wang, L., Dai, W., and Lu, L. (2007). Stress-induced c-Jun activation mediated by Polo-like kinase 3 in corneal epithelial cells. The Journal of biological chemistry 282, 32121-32127. 
Wang, L., Gao, J., Dai, W., and Lu, L. (2008a). Activation of Polo-like kinase 3 by hypoxic stresses. The Journal of biological chemistry $283,25928-25935$.

Wang, Q., Song, C., and Li, C.C. (2003a). Hexamerization of p97-VCP is promoted by ATP binding to the D1 domain and required for ATPase and biological activities. Biochemical and biophysical research communications 300, 253-260.

Wang, Q., Song, C., and Li, C.C. (2004a). Molecular perspectives on p97-VCP: progress in understanding its structure and diverse biological functions. Journal of structural biology 146, 44-57.

Wang, Q., Xie, S., Chen, J., Fukasawa, K., Naik, U., Traganos, F., Darzynkiewicz, Z., Jhanwar-Uniyal, M., and Dai, W. (2002). Cell cycle arrest and apoptosis induced by human Polo-like kinase 3 is mediated through perturbation of microtubule integrity. Molecular and cellular biology 22, 3450-3459.

Wang, Y., Satoh, A., and Warren, G. (2005). Mapping the functional domains of the Golgi stacking factor GRASP65. The Journal of biological chemistry 280, 4921-4928.

Wang, Y., Satoh, A., Warren, G., and Meyer, H.H. (2004b). VCIP135 acts as a deubiquitinating enzyme during p97-p47-mediated reassembly of mitotic Golgi fragments. The Journal of cell biology 164, 973-978.

Wang, Y., Seemann, J., Pypaert, M., Shorter, J., and Warren, G. (2003b). A direct role for GRASP65 as a mitotically regulated Golgi stacking factor. The EMBO journal 22, 3279-3290.

Wang, Y., Wei, J.H., Bisel, B., Tang, D., and Seemann, J. (2008b). Golgi cisternal unstacking stimulates COPI vesicle budding and protein transport. PloS one 3, e1647.

Wei, J.H., and Seemann, J. (2009a). Induction of asymmetrical cell division to analyze spindle-dependent organelle partitioning using correlative microscopy techniques. Nature protocols 4, 1653-1662.

Wei, J.H., and Seemann, J. (2009b). The mitotic spindle mediates inheritance of the Golgi ribbon structure. The Journal of cell biology 184, 391-397.

Wei, J.H., and Seemann, J. (2009c). Remodeling of the Golgi structure by ERK signaling. Communicative \& integrative biology 2, 35-36.

Wei, J.H., and Seemann, J. (2009d). Spindle-dependent partitioning of the Golgi ribbon. Communicative \& integrative biology 2, 406-407.

Weichert, W., Denkert, C., Schmidt, M., Gekeler, V., Wolf, G., Kobel, M., Dietel, M., and Hauptmann, S. (2004). Polo-like kinase isoform expression is a prognostic factor in ovarian carcinoma. In: Br J Cancer, vol. 90, 815-821.

Weichert, W., Kristiansen, G., Winzer, K.J., Schmidt, M., Gekeler, V., Noske, A., Muller, B.M., Niesporek, S., Dietel, M., and Denkert, C. (2005). Polo-like kinase isoforms in breast cancer: expression patterns and prognostic implications. Virchows Arch 446, 442-450. 
Wiebe, M.S., Nichols, R.J., Molitor, T.P., Lindgren, J.K., and Traktman, P. (2009). Mice Deficient in the Serine/Threonine Protein Kinase VRK1 Are Infertile Due to a Progressive Loss of Spermatogonia. Biology of reproduction.

Wiebe, M.S., and Traktman, P. (2007). Poxviral B1 kinase overcomes barrier to autointegration factor, a host defense against virus replication. Cell host $\&$ microbe 1 , 187-197.

Wiest, J., Clark, A.M., and Dai, W. (2001). Intron/exon organization and polymorphisms of the PLK3/PRK gene in human lung carcinoma cell lines. Genes, chromosomes \& cancer 32, 384-389.

Winkles, J.A., and Alberts, G.F. (2005). Differential regulation of polo-like kinase 1, 2, 3 , and 4 gene expression in mammalian cells and tissues. Oncogene 24, 260-266.

Wright, J.H., Munar, E., Jameson, D.R., Andreassen, P.R., Margolis, R.L., Seger, R., and Krebs, E.G. (1999). Mitogen-activated protein kinase kinase activity is required for the $\mathrm{G}(2) / \mathrm{M}$ transition of the cell cycle in mammalian fibroblasts. Proceedings of the National Academy of Sciences of the United States of America 96, 11335-11340.

Xiang, Y., Seemann, J., Bisel, B., Punthambaker, S., and Wang, Y. (2007). Active ADP-ribosylation factor-1 (ARF1) is required for mitotic Golgi fragmentation. The Journal of biological chemistry 282, 21829-21837.

Xiang, Y., and Wang, Y. (2010). GRASP55 and GRASP65 play complementary and essential roles in Golgi cisternal stacking

$\mathrm{J}$ Cell Biol

188, 237-251.

Xie, S., Wang, Q., Ruan, Q., Liu, T., Jhanwar-Uniyal, M., Guan, K., and Dai, W. (2004). MEK1-induced Golgi dynamics during cell cycle progression is partly mediated by Pololike kinase-3. Oncogene 23, 3822-3829.

Xie, S., Wang, Q., Wu, H., Cogswell, J., Lu, L., Jhanwar-Uniyal, M., and Dai, W. (2001a). Reactive oxygen species-induced phosphorylation of p53 on serine 20 is mediated in part by polo-like kinase-3. The Journal of biological chemistry 276, 3619436199.

Xie, S., Wu, H., Wang, Q., Cogswell, J.P., Husain, I., Conn, C., Stambrook, P., Jhanwar-Uniyal, M., and Dai, W. (2001b). Plk3 functionally links DNA damage to cell cycle arrest and apoptosis at least in part via the p53 pathway. The Journal of biological chemistry $276,43305-43312$.

Xie, S., Wu, H., Wang, Q., Kunicki, J., Thomas, R.O., Hollingsworth, R.E., Cogswell, J., and Dai, W. (2002). Genotoxic stress-induced activation of Plk3 is partly mediated by Chk2. Cell cycle (Georgetown, Tex 1, 424-429.

Xie, S., Xie, B., Lee, M.Y., and Dai, W. (2005). Regulation of cell cycle checkpoints by polo-like kinases. Oncogene 24, 277-286.

Yadav, S., Puri, S., and Linstedt, A.D. (2009). A primary role for Golgi positioning in directed secretion, cell polarity, and wound healing. Molecular biology of the cell 20, 1728-1736. 
Yaffe, M.B., and Elia, A.E. (2001). Phosphoserine/threonine-binding domains. Current opinion in cell biology 13, 131-138.

Yang, F., Camp, D.G., 2nd, Gritsenko, M.A., Luo, Q., Kelly, R.T., Clauss, T.R., Brinkley, W.R., Smith, R.D., and Stenoien, D.L. (2007). Identification of a novel mitotic phosphorylation motif associated with protein localization to the mitotic apparatus. J Cell Sci 120, 4060-4070.

Yang, J.S., Lee, S.Y., Spano, S., Gad, H., Zhang, L., Nie, Z., Bonazzi, M., Corda, D., Luini, A., and Hsu, V.W. (2005). A role for BARS at the fission step of COPI vesicle formation from Golgi membrane. The EMBO journal 24, 4133-4143.

Yang, Y., Bai, J., Shen, R., Brown, S.A., Komissarova, E., Huang, Y., Jiang, N., Alberts, G.F., Costa, M., Lu, L., Winkles, J.A., and Dai, W. (2008). Polo-like kinase 3 functions as a tumor suppressor and is a negative regulator of hypoxia-inducible factor1 alpha under hypoxic conditions. Cancer research 68, 4077-4085.

Ye, Y. (2006). Diverse functions with a common regulator: ubiquitin takes command of an AAA ATPase. Journal of structural biology 156, 29-40.

Ye, Y., Meyer, H.H., and Rapoport, T.A. (2003). Function of the p97-Ufd1-Npl4 complex in retrotranslocation from the ER to the cytosol: dual recognition of nonubiquitinated polypeptide segments and polyubiquitin chains. The Journal of cell biology 162, 71-84.

Yoshimura, S., Yoshioka, K., Barr, F.A., Lowe, M., Nakayama, K., Ohkuma, S., and Nakamura, N. (2005). Convergence of cell cycle regulation and growth factor signals on GRASP65. The Journal of biological chemistry 280, 23048-23056.

Zaal, K.J., Smith, C.L., Polishchuk, R.S., Altan, N., Cole, N.B., Ellenberg, J., Hirschberg, K., Presley, J.F., Roberts, T.H., Siggia, E., Phair, R.D., and LippincottSchwartz, J. (1999). Golgi membranes are absorbed into and reemerge from the ER during mitosis. Cell 99, 589-601.

Zelko, I., Kobayashi, R., Honkakoski, P., and Negishi, M. (1998). Molecular cloning and characterization of a novel nuclear protein kinase in mice. Archives of biochemistry and biophysics 352, 31-36.

Zhang, H., Wang, Q., Kajino, K., and Greene, M.I. (2000). VCP, a weak ATPase involved in multiple cellular events, interacts physically with BRCA1 in the nucleus of living cells. DNA and cell biology 19, 253-263.

Zimmerman, W.C., and Erikson, R.L. (2007a). Finding Plk3. Cell cycle (Georgetown, Tex 6, 1314-1318.

Zimmerman, W.C., and Erikson, R.L. (2007b). Polo-like kinase 3 is required for entry into $S$ phase. Proceedings of the National Academy of Sciences of the United States of America 104, 1847-1852. 

Parte del trabajo mostrado en esta Tesis Doctoral ha sido publicado en los siguientes artículos científicos:

Valbuena A, Inmaculada López-Sánchez, Vega FM, Sevilla A, Sanz-García M, Blanco S, Lazo PA (2007). Identification of a dominant epitope in human vacciniarelated kinase 1 (VRK1) and detection of different intracellular subpopulations. Arch Biochem Biophys. 2007 Sep 1;465(1):219-26.

Inmaculada López-Sánchez, Marta Sanz-García and Pedro A. Lazo (2009). Plk3 interacts with and specifically phosphorylates VRK1 in Ser342, a downstream target in a pathway that induces Golgi fragmentation. Mol Cell Biol. 2009 Mar;29(5):1189-201.

Otros artículos en los que el doctorando ha participado son:

Valbuena A, Inmaculada López-Sánchez, Lazo PA (2008). Human VRK1 is an early response gene and its loss causes a block in cell cycle progression. PLoS One. 2008 Feb 20;3(2):e1642.

Sanz-García M, Inmaculada López-Sánchez, Lazo PA (2008). Proteomics identification of nuclear Ran GTPase as an inhibitor of human VRK1 and VRK2 (vaccinia-related kinase) activities. Mol Cell Proteomics. 2008 Nov;7(11):2199-214. 



\section{Agradecimientos.}

I got by with a little help from my friends

Esta tesis nunca hubiera sido posible sin la muy variada participación de un grupo de personas a las que desde aquí quiero expresar mi más sincera gratitud. De alguna manera que no soy capaz de describir, todos ellos forman parte de estas páginas y, para siempre, del recuerdo de estos años de aprendizaje, trabajo y amistad.

A mi director de tesis, Pedro A. Lazo, le debo, en primer lugar, la confianza que supo poner en mí hace ya algunos años, y la comprensión y el apoyo que han sido tan necesarios para llevar cabo este proyecto.

La deuda con los compañeros del Centro de Investigación del Cáncer y, en particular, del Laboratorio 4 es larga y nunca podré pagarla: gracias por los consejos, los ánimos, el buen humor, la complicidad, los cafés a media mañana y los reactivos prestados. Sus recuerdos me acompañarán siempre allá donde me lleven la vida y nuestra profesión.

Sería injusto olvidarme de tantas otras personas que me regalaron su amistad y me acompañaron en este viaje que ahora finaliza. A su complicidad le debo el impulso que me hizo seguir adelante en los momentos más difíciles.

Y, por último, no puedo dejar de mencionar a mi familia y a Antonio. Sólo ellos saben las verdaderas dificultades que he tenido que superar para poder escribir estas líneas y que su participación en esta tesis excede cuanto aquí pueda agradecerles. De todos modos, gracias otra vez. 


